\title{
Development of a Three-Dimensional Ground-Water Model of the Hanford Site Unconfined Aquifer System: FY 1995 Status Report
}

\author{
S. K. Wurstner \\ P. D. Thorne \\ M. A. Chamness \\ M. D. Freshley \\ M. D. Williams
}

December 1995

Prepared for

the U.S. Department of Energy

under Contract DE-AC06-76RLO 1830

Pacific Northwest National Laboratory

Richland, Washington 99352 


\section{DISCLAMMER}

Portions of this document may be illegible in electronic image products. Images are produced from the best available original document. 


\section{Executive Summary}

A three-dimensional ground-water flow model has been developed for the uppermost unconfined aquifer at the Hanford Site in south-central Washington. This model is being developed to support the Hanford Site Ground-Water Surveillance Project objectives of 1) identifying and quantifying existing, emerging, or potential ground-water quality problems, and 2) assessing the potential for contaminants to migrate from the Hanford Site through the groundwater pathway.

The approach to develop the three-dimensional model was to 1) refine the conceptual hydrogeologic model, 2) calibrate a two-dimensional version of the model with an inverse calibration method, and 3) develop the three-dimensional model based on all available information. The model is based on the Coupled Fluid, Energy, and Solute Transport (CFEST) code; however, the database of geologic and hydrologic information is constructed so that the conceptual model can be implemented in codes other than CFEST.

The model consists of 10 hydrogeologic layers. Layers 1 through 9 correspond to the hydrogeologic units comprising the unconfined aquifer system. Layer 10 corresponds to basalt. The conceptual model was developed using the ground surface as the top of the model. The numerical model uses only the saturated portion of the sediments below the ground surface (i.e., the unconfined aquifer). Hydraulic conductivities were assigned to layers based on data from aquifer pumping tests, slug tests, and some laboratory tests. Some layers were assigned a constant value of hydraulic conductivity, while others were zoned with different hydraulic conductivities being assigned to each zone. The goal of the three-dimensional model calibration was to preserve the total transmissivity calculated by the two-dimensional inverse calibration, while honoring data available for hydrogeologic layers.

The model grid consists of 821 surface nodes and 721 surface elements. The placement of nodes in the grid was selected so that 1) sources would be represented as closely as possible by nodes, 2) potential contours and gradients could be resolved, and 3) geologic layer extents and other important three-dimensional hydrogeologic aspects of the problem could be represented as accurately as possible. Boundary and source conditions used in the model are similar to previous 
efforts at the Site. A natural areal recharge distribution was included to reflect infiltration and recharge to the unconfined aquifer.

Steady-state predictions from the three-dimensional model for the 1979 calibration period compared well with the observed water table. There is close agreement in most areas of the Site. The three-dimensional model is ready for routine application in steady-state, and we are proceeding with the construction of transport models for tritium, iodine-129, and nitrate based on the flow model.

In addition to the three-dimensional model development, the existing two-dimensional model was applied during fiscal year 1995 to address several problems at the Site: 1) evaluation of the C-018H permit; 2) evaluation of a Washington Public Power Supply System (WNP-2) permit application; and 3) travel time estimates from Pit 9. 


\section{Acknowledgements}

Several people contributed to the development of this report. The authors thank Micki McKinley and Bill Webber for generating many of the figures in this report. John McDonald contributed to several of the model application efforts and generated some figures for this report. Charlie Cole provided technical support in developing the numerical model and provided a technical peer review. Thanks and appreciation also go to Stuart Luttrell and Doug Hildebrand for reviewing this document and providing comments. 


\section{Contents}

Executive Summary $\ldots \ldots \ldots \ldots \ldots \ldots \ldots \ldots \ldots \ldots \ldots \ldots \ldots \ldots \ldots \ldots \ldots \ldots \ldots$

Acknowledgements $\ldots \ldots \ldots \ldots \ldots \ldots \ldots \ldots \ldots \ldots \ldots$

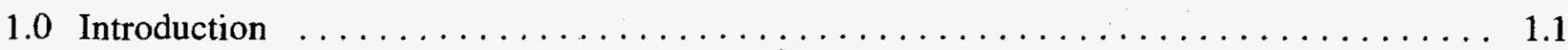

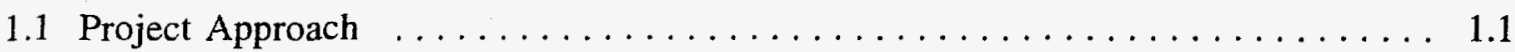

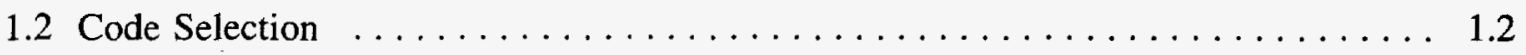

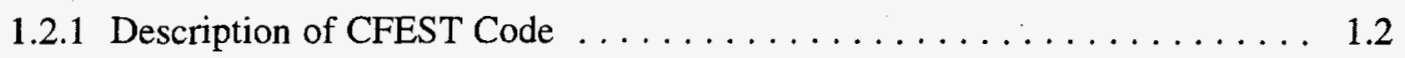

1.2.2 Physical Processes Modeled by CFEST $\ldots \ldots \ldots \ldots \ldots \ldots \ldots \ldots \ldots . \ldots \ldots$

1.2 .3 Aquifer Geometry $\ldots \ldots \ldots \ldots \ldots \ldots \ldots \ldots \ldots \ldots \ldots \ldots \ldots \ldots$

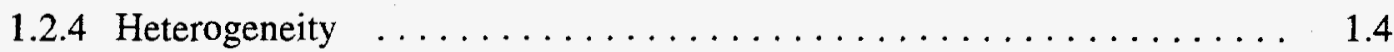

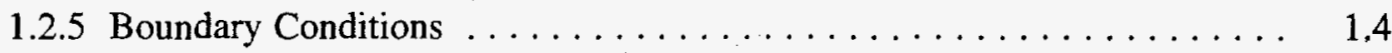

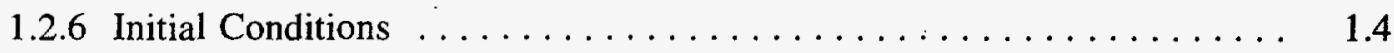

1.3 Other Modeling Efforts at the Hanford Site $\ldots \ldots \ldots \ldots \ldots \ldots \ldots \ldots \ldots \ldots$

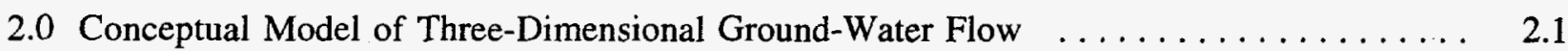

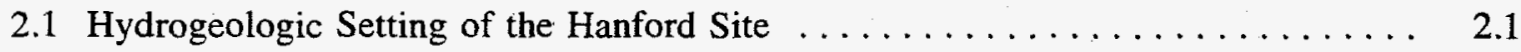

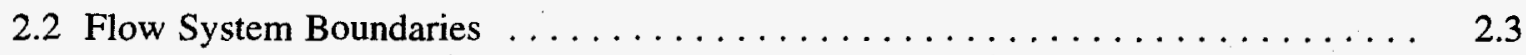

2.2.1 Columbia River Boundary $\ldots \ldots \ldots \ldots \ldots \ldots \ldots \ldots \ldots \ldots \ldots \ldots \ldots \ldots \ldots \ldots \ldots .4 .4$

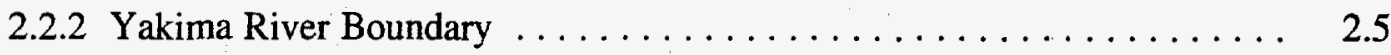

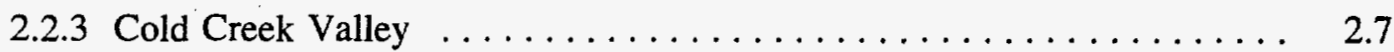

2.2.4 Interflow with the Basalt Confined Aquifer System . . . . . . . . 2.7

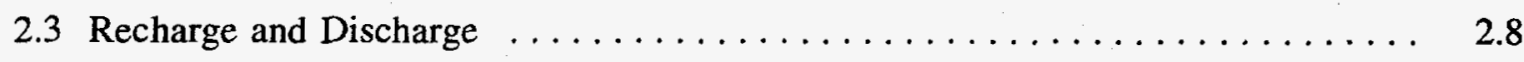

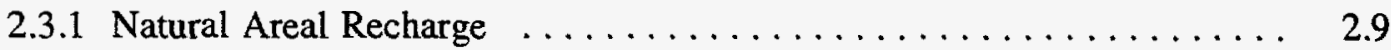

2.3.2 Artificial Recharge $\ldots \ldots \ldots \ldots \ldots \ldots \ldots \ldots \ldots \ldots \ldots \ldots . \ldots \ldots$

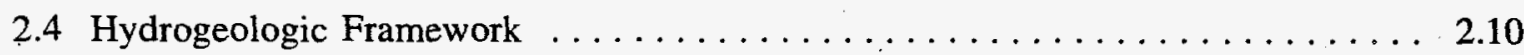

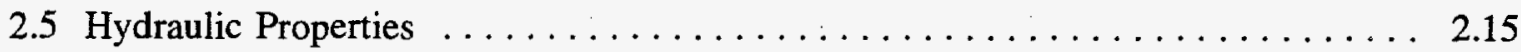

2.5.1 Hydraulic Conductivity of Hydrogeologic Units . . . . . . . 2.16

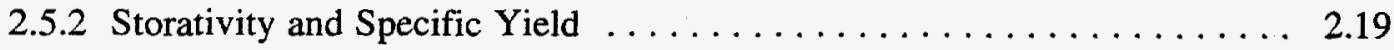

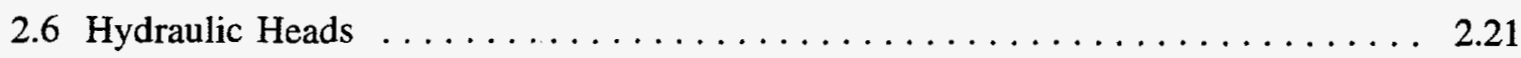

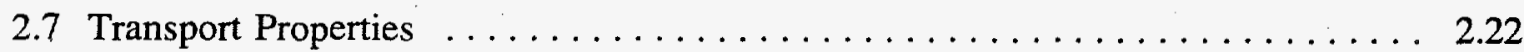

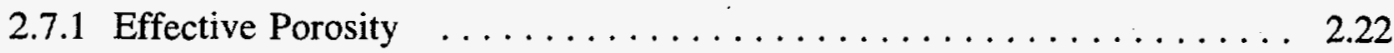

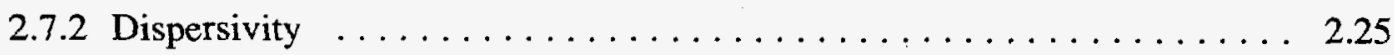

2.8 Contaminant Distributions $\ldots \ldots \ldots \ldots \ldots \ldots \ldots \ldots \ldots \ldots \ldots \ldots \ldots \ldots \ldots \ldots \ldots \ldots \ldots \ldots .27$ 


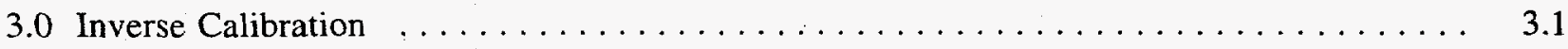

3.1 Description of Previous Model Calibrations $\ldots \ldots \ldots \ldots \ldots \ldots \ldots \ldots \ldots \ldots$

3.2 Description of CFEST Inverse $\ldots \ldots \ldots \ldots \ldots \ldots \ldots \ldots \ldots \ldots \ldots \ldots \ldots \ldots \ldots \ldots \ldots \ldots \ldots .2$

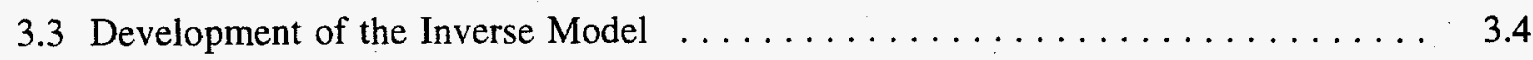

3.3.1 Selection of Steady-State Time Period $\ldots \ldots \ldots \ldots \ldots \ldots \ldots \ldots . \ldots \ldots$

3.3.2 Hydraulic Head Data Preparation $\ldots \ldots \ldots \ldots \ldots \ldots \ldots \ldots \ldots . \ldots \ldots$

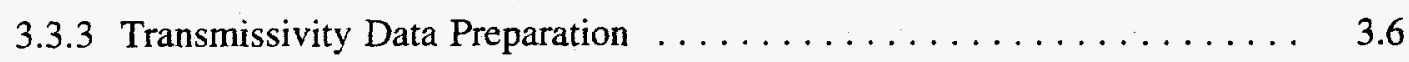

3.3 .4 Boundary Condition Input $\ldots \ldots \ldots \ldots \ldots \ldots \ldots \ldots \ldots \ldots \ldots \ldots$

3.3.5 Artificial Recharge Input $\ldots \ldots \ldots \ldots \ldots \ldots \ldots \ldots \ldots \ldots \ldots \ldots \ldots .7$

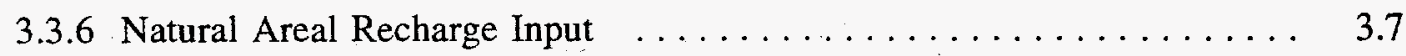

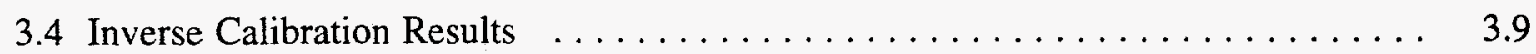

4.0 Three-Dimensional Numerical Model $\ldots \ldots \ldots \ldots \ldots \ldots \ldots \ldots \ldots \ldots \ldots \ldots \ldots .1$

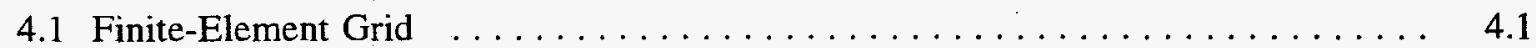

4.2 Incorporation of Hydrogeologic Layers $\ldots \ldots \ldots \ldots \ldots \ldots \ldots \ldots \ldots \ldots \ldots$

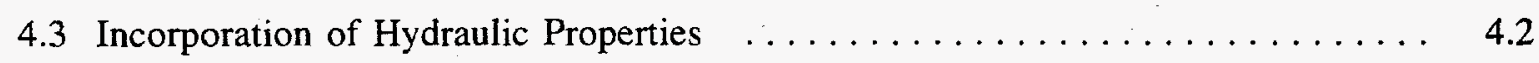

4.4 Incorporation of Boundary Conditions $\ldots \ldots \ldots \ldots \ldots \ldots \ldots \ldots \ldots \ldots$

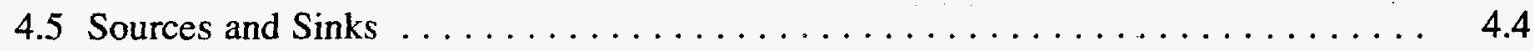

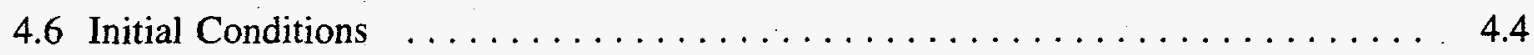

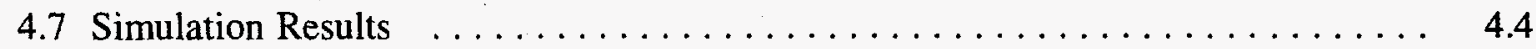

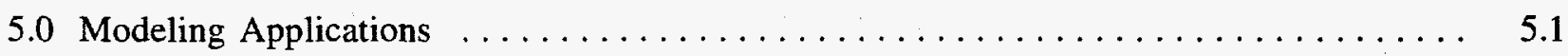

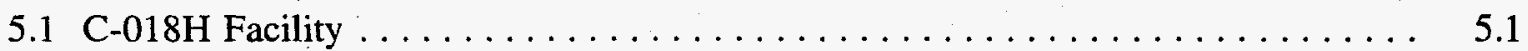

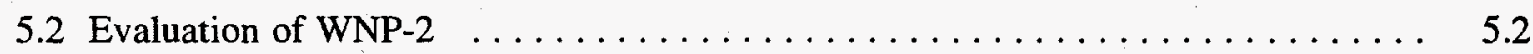

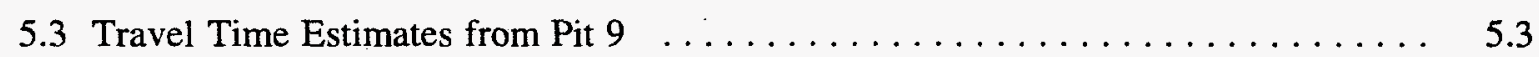

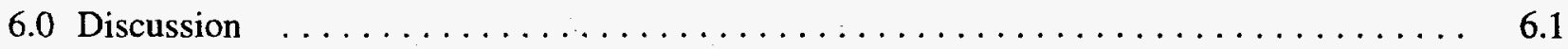

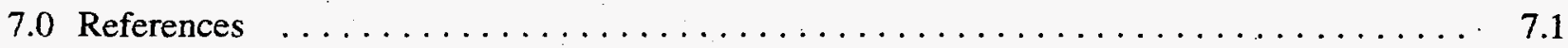

Appendix A Analysis of a Richland City Well Pumping Test $\ldots \ldots \ldots \ldots \ldots \ldots \ldots \ldots$

Appendix B Analysis of the $200-$ West Area Ground-Water Mound $\ldots \ldots \ldots \ldots \ldots$ B.1

Appendix C Available Transmissivity Data Obtained from Pumping Tests in the Unconfined Aquifer System $\ldots \ldots \ldots \ldots \ldots \ldots \ldots \ldots \ldots \ldots \ldots \ldots \ldots \ldots$ 
Appendix D Well Cluster Sites and Wells with Piezometers in the Unconfined Aquifer System

D. 1 


\section{Figures}

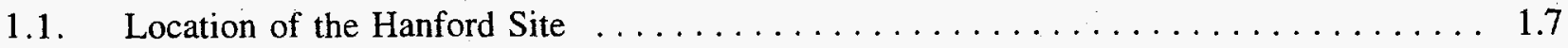

2.1 Surface Geology and Structural Features of the Pasco Basin $\ldots \ldots \ldots \ldots \ldots$

2.2 Yakima River Stage and Water Level Elevations in the Unconfined and Confined

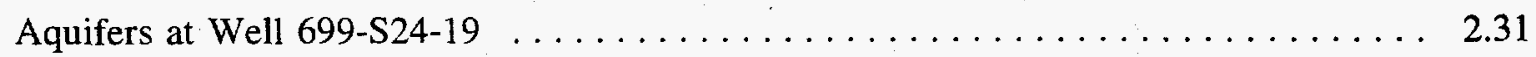

2.3 Comparison of Observed Hydraulic Heads for the Upper Basalt and Overlying Unconfined Aquifer Systems $\ldots \ldots \ldots \ldots \ldots \ldots \ldots \ldots \ldots \ldots \ldots \ldots \ldots \ldots \ldots \ldots \ldots \ldots . .32$

2.4 Hanford Site Water Supply Wells $\ldots \ldots \ldots \ldots \ldots \ldots \ldots \ldots \ldots \ldots \ldots \ldots \ldots$

2.5 Natural Recharge Distribution for the Hanford Site $\ldots \ldots \ldots \ldots \ldots \ldots \ldots \ldots$

$2.6 \quad$ Hanford Effluent Discharge Sites $\ldots \ldots \ldots \ldots \ldots \ldots \ldots \ldots \ldots \ldots \ldots \ldots \ldots$

2.7 Hydrograph of Waste Streams at the Hanford Site 1979 to $1994 \ldots \ldots \ldots \ldots$

2.8 Comparison of Generalized Geology and Hydrogeologic Stratigraphic

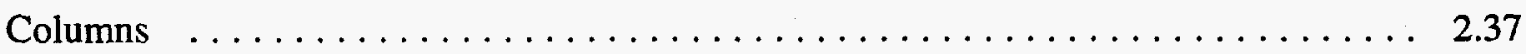

2.9 Distribution of Wells Used to Define Three-Dimensional Hydrogeologic Structure $\ldots 2.38$

2.10 Structure Contour Map of Top of Basalt, Based on Model Input, $1995 \ldots \ldots . \ldots$

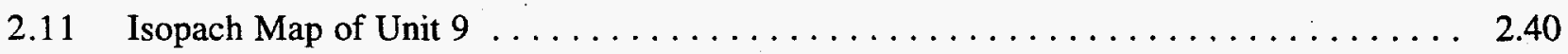

2.12 Distribution of Wells Where Unit 9 Was Identified $\ldots \ldots \ldots \ldots \ldots \ldots \ldots \ldots$

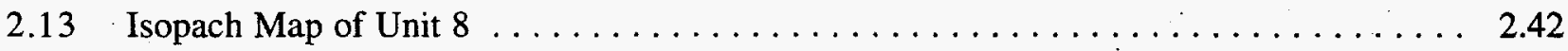

2.14 Distribution of Wells Where Unit 8 Was Identified $\ldots \ldots \ldots \ldots \ldots \ldots \ldots$

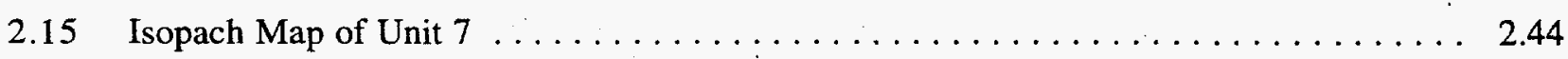


2.16 Distribution of Wells Where Unit 7 Was Identified

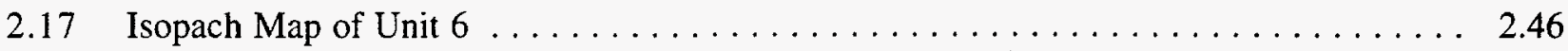

2.18 Distribution of Wells Where Unit 6 Was Identified $\ldots \ldots \ldots \ldots \ldots \ldots \ldots$

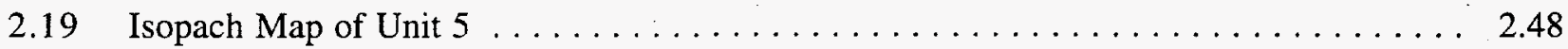

2.20 Distribution of Wells Where Unit 5 Was Identified $\ldots \ldots \ldots \ldots \ldots \ldots \ldots \ldots \ldots$

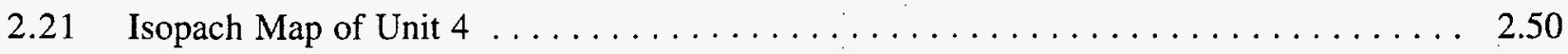

2.22 Distribution of Wells Where Unit 4 Was Identified $\ldots \ldots \ldots \ldots \ldots \ldots \ldots \ldots \ldots$

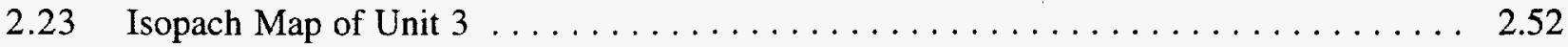

2.24 Distribution of Wells Where Unit 3 Was Identified $\ldots \ldots \ldots \ldots \ldots \ldots \ldots \ldots$

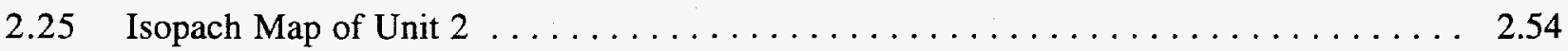

2.26 Distribution of Wells Where Unit 2 Was Identified $\ldots \ldots \ldots \ldots \ldots \ldots \ldots \ldots$

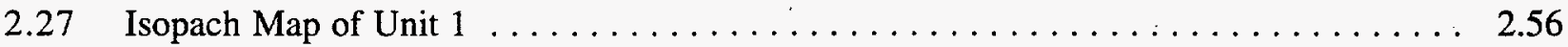

2.28 Distribution of Wells Where Unit 1 Was Identified $\ldots \ldots \ldots \ldots \ldots \ldots \ldots \ldots$

2.29 Distribution of Wells With Hydraulic Property Measurements for Different Units . . . . 2.58

2.30 Geologic Units Present at the Water Table, June $1993 \ldots \ldots \ldots \ldots \ldots \ldots \ldots$

2.31 Map Showing Location of Selected Wells with Individual Piezometers $\ldots \ldots \ldots \ldots$

3.1 Finite-Element Grid Showing Boundary Conditions $\ldots \ldots \ldots \ldots \ldots \ldots \ldots \ldots$

3.2 Observed (Measured) Water-Level Distribution Used in the

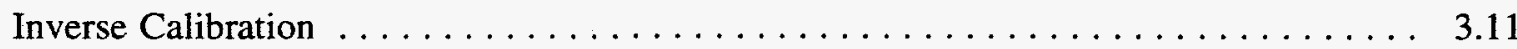


3.3 Wells and Aquifer Test Results (Transmissivities in $\mathrm{m}^{2} / \mathrm{d}$ ) Used in the Inverse Calibration $\ldots \ldots \ldots \ldots \ldots \ldots \ldots \ldots \ldots \ldots \ldots \ldots \ldots \ldots \ldots \ldots \ldots \ldots \ldots \ldots .12$

3.4 Transmissivity Zonation Used in the Inverse Calibration $\ldots \ldots \ldots \ldots \ldots \ldots \ldots$

3.5 Estimated Natural Recharge Rates $(\mathrm{m} / \mathrm{d})$ Used in the Inverse Calibration $\ldots \ldots \ldots 3.15$

3.6 Transmissivity Distribution Obtained from the Inverse Solution $\ldots \ldots \ldots \ldots .17$

3.7 Predicted Heads Compared with Observed Using Transmissivities from the Inverse

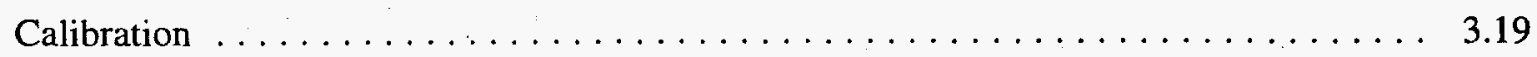

3.8 Histogram Distribution of Transmissivity Values from the

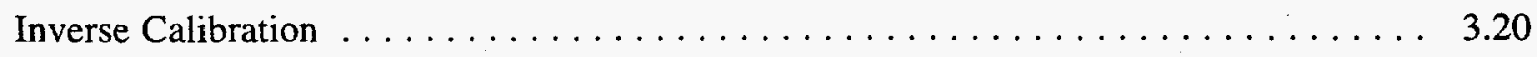

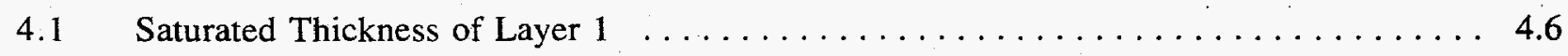

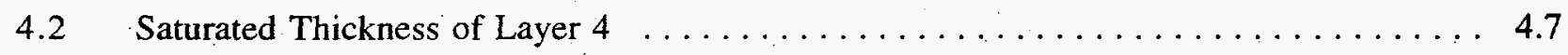

$4.3 \quad$ Saturated Thickness of Layer $5 \ldots \ldots \ldots \ldots \ldots \ldots \ldots \ldots \ldots \ldots \ldots \ldots$

$4.4 \quad$ Hydraulic Conductivity Zones for Layer $6 \ldots \ldots \ldots \ldots \ldots \ldots \ldots$

$4.5 \quad$ Hydraulic Conductivity Zones for Layer $1 \ldots \ldots \ldots \ldots \ldots \ldots \ldots \ldots \ldots \ldots$

$4.6 \quad$ Hydraulic Conductivity Zones for Layer $5 \ldots \ldots \ldots \ldots \ldots \ldots \ldots \ldots \ldots \ldots$

4.7 Steady-State Results of the Three-Dimensional Model Compared to Results of the Inverse Calibration $\ldots \ldots \ldots \ldots \ldots \ldots \ldots \ldots \ldots \ldots \ldots \ldots \ldots \ldots \ldots \ldots \ldots \ldots \ldots \ldots .15$

4.8 Steady-State Results of the Three-Dimensional Model Compared to the Observed Water Table $\quad \ldots \ldots \ldots \ldots \ldots \ldots \ldots \ldots \ldots \ldots \ldots \ldots \ldots \ldots \ldots \ldots \ldots \ldots \ldots$

$5.1 \quad$ Predicted Water-Table Contours for December $2040 \ldots \ldots \ldots \ldots \ldots \ldots \ldots$

5.2 Potential Flow Paths Starting in the Vicinity of the $\mathrm{C}-018 \mathrm{H}$ Facility $\ldots \ldots \ldots . \ldots$ 
5.3 Tritium Concentrations Along Pathlines from the C-018H Facility for Four

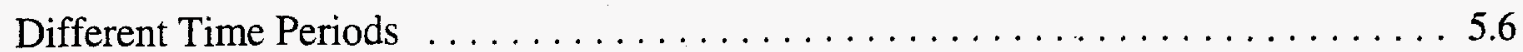

5.4 Predicted Concentration of Tritium After 5 years of Facility Operation Using the Average Source Concentration

5.5 Predicted Concentration of Tritium After 5 years of Facility Operation Using the

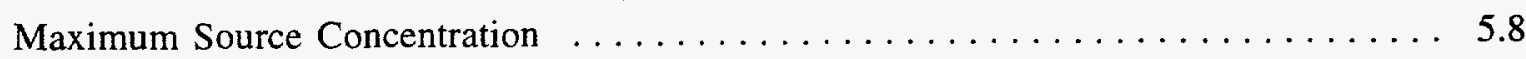

5.6 Water Table Contours for December 1992 with WNP-2 Discharges $\ldots \ldots \ldots \ldots$

5.7 Water Table Contours for December 1992 without WNP-2 Discharges $\ldots \ldots \ldots . \ldots$

$5.8 \quad$ Pathlines From Pit 9 to the Columbia River $\ldots \ldots \ldots \ldots \ldots \ldots \ldots \ldots \ldots \ldots \ldots$ 


\section{Tables}

$2.1 \quad$ Hydraulic Test Results for Mud-Dominated Units $\ldots \ldots \ldots \ldots \ldots \ldots \ldots \ldots$

$2.2 \quad$ Multiple Well Test Results $\ldots \ldots \ldots \ldots \ldots \ldots \ldots \ldots \ldots \ldots \ldots \ldots \ldots \ldots \ldots \ldots$

2.3 List of Selected Wells with Individual Piezometers Open to Different Depth Intervals . . 2.23

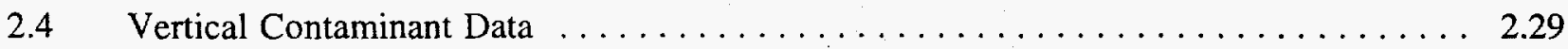

3.1 Summary of Major Discharges to the Ground at Facilities in the 200-East and 200-West

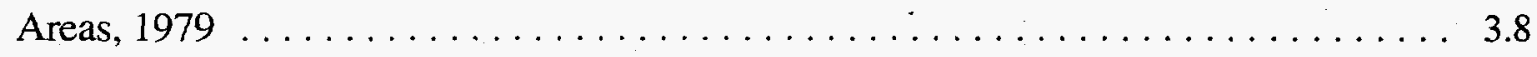




\subsection{Introduction}

A three-dimensional numerical model of ground-water flow was developed for the uppermost unconfined aquifer at the Hanford Site in south-central Washington (Figure 1.1). Development of the model is supported by the Hanford Site Ground-Water Surveillance Project, managed by the Pacific Northwest National Laboratory(a), which is responsible for monitoring the sitewide movement of contaminants in ground water beneath the Hanford Site. Two objectives of the Ground-Water Surveillance Project are to 1) identify and quantify existing, emerging, or potential ground-water quality problems, and 2) assess the potential for contaminants to migrate from the Hanford Site through the ground-water pathway. Numerical models of the ground-water flow system are important tools for estimating future aquifer conditions and predicting the movement of contaminants through ground water. The Ground-Water Surveillance Project has supported development and maintenance of a two-dimensional model of the unconfined aquifer (Wurstner and Devary 1993). This report describes upgrade of the two-dimensional model to a three-dimensional model.

The numerical model is based on a three-dimensional conceptual model that will be continually refined and updated as additional information becomes available. This report presents a description of the three-dimensional conceptual model of ground-water flow in the unconfined aquifer system and then discusses the current state of the three-dimensional numerical model.

\subsection{Project Approach}

Two-dimensional flow models have been used extensively at the Hanford Site and are generally adequate for predicting aquifer head changes and directions of ground-water flow. However, a three-dimensional model is needed for accurate calculation of mass transport and predictions of contaminant concentrations. Advantages of a three-dimensional model include

- vertical heterogeneity of the aquifer is taken into account

- vertical dispersion can be simulated

- the effect of vertical gradients on contaminants is not ignored

(a) Pacific Northwest National Laboratory is operated for the U.S. Department of Energy by Battelle. 
- mass balance of contaminants is preserved

- mass flux can be calculated.

Accounting for vertical heterogeneity is particularly important for an unconfined aquifer if future water-table changes result in either the dewatering of a hydrogeologic layer or flow through a previously unsaturated layer. At Hanford, the water table is near the contact between the Hanford formation and the underlying, and much less permeable, Ringold Formation over a large part of the Site. Water level declines caused by decreased dịscharge to disposal facilities will cause dewatering of the highly permeable Hanford formation sediments in some areas. This may result in aquifer transmissivity changes of an order of magnitude or more that would not be not accounted for by two-dimensional flow models. The resulting changes in ground-water flow direction are also not accurately simulated by a two-dimensional model. Not properly accounting for the threedimensional layering and its effects on transport leads to incorrect prediction of contaminant transport.

The approach used for development of a fully three-dimensional model of the Hanford Site unconfined aquifer was to 1) refine the conceptual model, 2) calibrate a two-dimensional model with an inverse calibration method, and 3) develop a numerical model based on the three-dimensional conceptualization that preserves the two-dimensional calibration results.

\subsection{Code Selection}

The CFEST (Coupled Fluid, Energy, and Solute Transport [Gupta et al. 1987]) code was selected for upgrade of Pacific Northwest National Laboratory's two-dimensional model because it is well established at the Hanford Site. CFEST has been used to model the Hanford Site and a number of other sites in three dimensions (Dove et al. 1982; Cole et al. 1984; Gale et al. 1987; Foley et al. 1995). Evans et al. (1988) discusses selection of CFEST for application to the unconfined aquifer.

\subsubsection{Description of CFEST Code}

The CFEST code was originally designed to support the radioactive waste repository investigations sponsored by the U.S. Department of Energy's (DOE) Civilian Radioactive Waste 
Management Program. It has also been effectively used by the chemical waste management community for conducting exposure assessments, evaluating remediation alternatives, and designing extraction and control systems for aquifers. CFEST is an approved code for working on Hanford Federal Facility Agreement and Consent Order (Tri-Party Agreement) milestones related to risk assessment (DOE 1991).

The CFEST software library was extensively tested and brought under strict software quality assurance/quality control procedures by the Office of Nuclear Waste Isolation (ONWI). A super-computer version (CFEST-SC) was developed to run on all major Unix workstations (Cole et al. 1988). The CFEST output is now graphically displayed using the $A R C / I N F O(b)$ geographic information system (GIS).

\subsubsection{Physical Processes Modeled by CFEST}

The CFEST code solves partial differential equations for fluid pressure, temperature, and solute concentration for multilayered, confined hydrologic systems using the finite-element method. Options exist to solve the equations for pressure, temperature, and solute concentration in either an uncoupled or a coupled form. Fluid properties of density and viscosity are used to couple the equations for simulations requiring variable density solutions. Solution of the system of coupled equations is based on linearization, with the latest iteration of known pressure, temperature, and solute concentration used to compute fluid and aquifer properties for the next iteration.

Phreatic (unconfined) solutions can be computed for the uncoupled equations through an iterative technique that adjusts the saturated thickness so that the calculated head is the top of the system. The user has the option to solve for any or all of the dependent variables. The code is designed to simulate transient or steady-state fluid flow coupled with energy and/or solute transport. Because Hanford simulations currently do not consider differences in fluid density or viscosity, only the uncoupled equation option is used for Hanford Site simulations.

(b) ARC/INFO is a registered trademark of Environmental Systems Research Institute, Inc., Redlands, California. 


\subsubsection{Aquifer Geometry}

In the Cartesian coordinate system, the CFEST code can be used for simulation in a horizontal plane, a vertical plane, or a fully three-dimensional regime. An option also exists for the axisymmetric analysis of a vertical cross section.

The CFEST finite-element formulation has the capability to model discontinuities, major breaks in slope or thickness, and fault zones in individual hydrogeologic units. Surface-water bodies (lake, river, seashore), recharge or pumping wells, and variations in major land uses may be modeled using the appropriate grid (node locations).

\subsubsection{Heterogeneity}

The code models heterogeneity in aquifer permeability and porosity. Anisotropy (co-linear with the Cartesian coordinates) is also accommodated. Hydraulic and transport properties (i.e., material properties) are homogeneous within a given element. As a result, material properties within a given geologic layer can be specified as homogeneous or, at the other extreme, specified as variable (heterogeneous) on an element-by-element basis. This allows for varying degrees of geologic complexity.

\subsubsection{Boundary Conditions}

The code includes options for both constant and time-variant Dirichlet and Neumann boundary conditions. The Dirichlet and Neumann boundary conditions can be specified individually for each dependent variable. For example, a given node may have a specified concentration (Dirichlet) as well as a specified fluid flux (Neumann).

\subsubsection{Initial Conditions}

The user can specify the following initial conditions:

a) Hydraulic Head or Pressure -- Constant values for hydraulic head or pressure are specified throughout the region for cases of constant and variable density. 
b) Temperature -- Constant temperature, temperature as a function of depth, or independent nodal values of temperature may be specified at each node.

c) Concentration -- Constant or independent nodal values of concentration may be specified at each node.

\subsection{Other Modeling Efforts at the Hanford Site}

Numerical ground-water flow and contaminant transport models have been used previously in the Ground-Water Surveillance Project to simulate the impacts of Site operations on the rate and direction of ground-water flow and contaminant movement in the unconfined aquifer. Models were initially developed during the 1970s for use on the Hanford Site. A ground-water flow model based on the Variable Thickness Transient (VTT) code (Kipp et al. 1972) was developed and calibrated to existing data. The model was calibrated with a transient inverse calibration procedure involving an iterative routine (a streamtube approach) that used available field measurements of transmissivity (Cearlock et al. 1975). The calibrated model was used to simulate ground-water flow and predict flow paths in the unconfined aquifer.

A contaminant transport model based on the Multicomponent Mass Transport (MMT) code (Ahlstrom et al. 1977) was applied to simulate movement of the observed tritium plume in the unconfined aquifer between Hanford's 200-East Area and the Columbia River. The MMT code predicts contaminant transport by advection with a random component describing dispersion.

The Hanford Pathline Calculational code (Friedrichs et al. 1977) was developed and applied to predict advective transport of contaminants along selected pathlines in the unconfined aquifer that were predicted with the VTT code. A later modification of the streamtube approach, the TRANSS code, was developed by Simmons et al. (1986). The VTT and TRANSS codes were applied as part of the Hanford Defense Waste Environmental Impact Statement, and their development and application are described by DOE (1987). Other applications of VTT, MMT, and TRANSS are described by Freshley and Graham (1988).

Work was initiated in the mid-1980s to develop two- and three-dimensional models of ground-water flow based on the CFEST code (Gupta et al. 1987). The CFEST code was selected 
because of its ability to simulate both ground-water flow and contaminant transport. The development and application of the CFEST code for unconfined aquifer studies are described by Evans êt al. (1988).

A steady-state inverse calibration method developed by Neuman and Yakowitz (1979) and modified by Jacobson (1985) was applied to calibrate the two-dimensional ground-water flow model of the unconfined aquifer based on CFEST. Both the inverse calibration method and the CFEST code are based on finite elements, so they are compatible. All information for estimates of aquifer hydraulic properties (e.g., transmissivities), hydraulic heads, boundary conditions, and discharges to and withdrawals from the aquifer is included in the inverse calibration for the groundwater flow model of the unconfined aquifer. Initial efforts on the inverse calibration are described by Evans et al. (1988) and the final calibration results are described by Jacobson and Freshley (1990).

More recent efforts with the two-dimensional ground-water flow model based on the CFEST code are described in Wurstner and Devary (1993) and Wurstner and Freshley (1994). Initial conditions for hydraulic head in the two-dimensional model are based on 1979 flow conditions, which were used by the steady-state inverse calibration as the criteria for generating transmissivities (Jacobson and Freshley 1990). The aquifer thickness included all saturated sediments above the Ringold lower mud unit or above the top of the basalt where the lower mud is absent. An aquifer specific yield value of 0.35 was used because it falls within the range of observed data and provides the best match to measured head values for transient simulations.

Other contractors on the Hanford Site have developed and applied ground-water flow and contaminant transport models. Connelly et al. (1992a) and Connelly et al. (1992b) developed models of the 200-East and 200-West Areas to support Resource Conservation and Recovery Act (RCRA) and Comprehensive Environmental Response, Compensation, and Liability Act (CERCLA) investigations. Golder Associates constructed a sitewide model that was used to support RCRA permit applications. More recently, Bechtel Hanford Inc. and Westinghouse Hanford Company have been developing a two-layer model of the unconfined aquifer based on the VAM-3D code. 


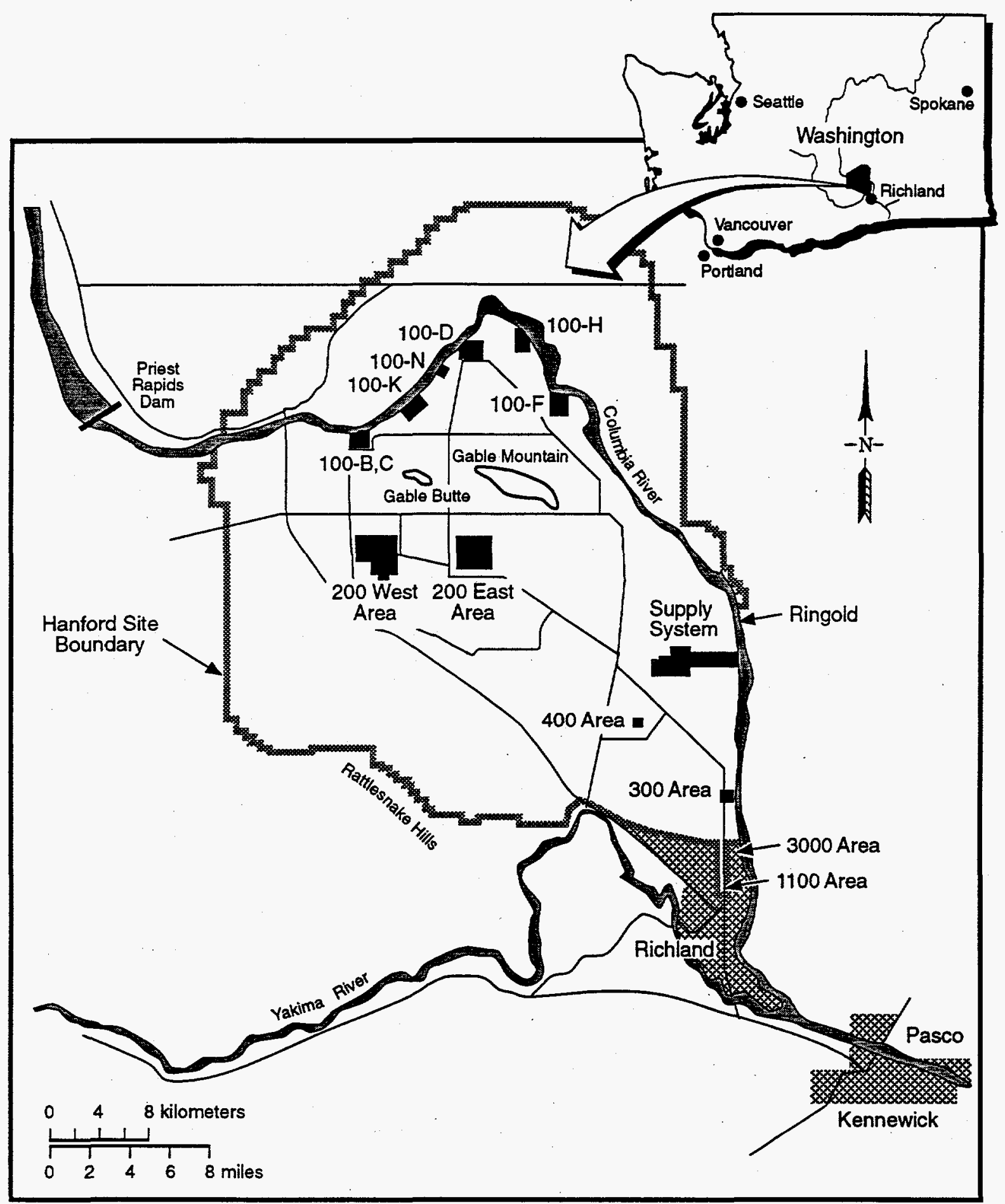

S9311035.1

Figure 1.1. Location of the Hanford Site 
0

-

○ 


\subsection{Conceptual Model of Three-Dimensional Ground-Water Flow}

This section describes the current three-dimensional conceptual model of the Hanford Site unconfined aquifer system, which is the uppermost aquifer across most of the Site. The conceptual model was constructed from data on the ground-water flow system and inferences that can be drawn from the data. For example, water level measurements in wells are a part of the available data and directions of ground-water flow can be inferred from these data. The conceptual model was also developed from information on the hydrogeologic structure of the aquifer, spatial distributions of hydraulic and transport properties, aquifer boundary conditions, and the distribution and movement of contaminants. Separate annual reports document the observed movement of chemical and radiological contaminant plumes in Hanford Site ground water and the measured elevations of the water table across the Site (for example, see Dresel et al. 1995). Earlier status reports on development of the three-dimensional conceptual model are presented in Thorne and Chamness (1992), and Thorne et al. (1993, 1994).

\subsection{Hydrogeologic Setting of the Hanford Site}

The Hanford Site and adjacent areas north and east of the Columbia River lie within the Pasco Basin, a structural depression that has accumulated a relatively thick sequence of fluvial, lacustrine, and glaciofluvial sediments. Figure 2.1 shows the surface geology and major structural features of the area. Hanford Site geology and hydrology have been studied extensively for approximately 50 years. Detailed summaries are provided in DOE (1988), Delaney et al. (1991), Lindsey et al. (1992), Lindsey (1995), and Cushing (1995). Consequently, the general geology and hydrology of the Site is only briefly covered here.

The Pasco Basin and nearby anticlines and synclines initially developed in the underlying Columbia River Basalt Group, a sequence of continental flood basalts covering more than $160,000 \mathrm{~km}^{2}$ (DOE 1988). These basalt flows erupted as fluid, molten lava during the late Tertiary Period. The most recent, laterally extensive basalt flow underlying the Hanford Site is the Elephant Mountain Member of the Saddle Mountains Basalt Formation, although the even younger Ice Harbor Member is found in the southern part of the Site (DOE 1988). Sandwiched between 
various basalt flows are sedimentary interbeds collectively called the Ellensburg Formation. The Ellensburg Formation includes fluvial and lacustrine sediments consisting of mud, sand, and gravel which, along with the porous basalt flow tops and bottoms, form confined basalt aquifers across the basin. The Rattlesnake Ridge Interbed is the uppermost laterally extensive interbed and confined basalt aquifer of the Ellensburg Formation (Spane and Vermeul 1994).

Overlying the basalt within the Pasco Basin are fluvial and lacustrine sediments of the Ringold Formation (Newcomb and Strand 1953; DOE 1988; Lindsey et al. 1992). The ancestral Columbia River and its tributaries flowed into the Pasco Basin, depositing coarse-grained sediments in the migrating river channels and fine-grained sediments (silt and clay) in the overbank flood deposits. On at least two occasions, these river channels were blocked, forming a lake in the Pasco Basin and depositing extensive layers of fine-grained sediments within the Ringold Formation. The Plio-Pleistocene unit, consisting of a paleosol/calcrete and/or basaltic sidestream sediments, and the early "Palouse" soil, an eolian sand and silt deposit, overlie the Ringold Formation, but are present only in the western portion of the Pasco Basin. The uppermost sedimentary unit covering much of the Hanford Site is the Hanford formation, a complex series of coarse- and fine-grained sediments deposited by cataclysmic floods (called the Missoula floods) during the last ice age. For the most part, the fine-grained sediments are found near the margins of the basin and in areas protected from the main flood currents, which deposited the coarse-grained sediments. Capping the Hanford formation in many areas is a thin veneer of eolian sands and/or recent fluvial deposits.

The fine-grained layers of the Ringold Formation have a much lower permeability than the coarse-grained layers, forming aquitards. However, these aquitards are usually not continuous across the Hanford Site, allowing interflow between different parts of the suprabasalt aquifer on a sitewide scale. Consequently, the suprabasalt aquifer is considered one entity commonly referred to as the "Hanford unconfined aquifer system."

As the post-basalt sediments were being deposited, the Pasco Basin continued to undergo structural deformation (DOE 1988). The basin continued to subside, and the ridges continued to rise. This process caused sedimentary units to be thickest in the center of the basin and thin or, in places, pinch out along the anticlines. Hanford formation sediments directly overlie the basalt in a few places where the Ringold Formation either was never deposited or was eroded away by the ancestral Columbia River and its tributaries prior to the Missoula floods. Missoula floodwaters further eroded sediment and basalt in some areas. Two known vertical faults, the Cold Creek and 
May Junction faults, were also developing as the older Ringold sediments were being deposited. Faulting is thought to have occurred until middle Ringold time, with a maximum vertical offset of $150 \mathrm{~m}$; there is no evidence of activity on these faults since that time (Johnson et al. 1993). The Cold Creek fault is known to affect hydraulic heads in the confined basalt aquifers; however, it is not clear if the unconfined aquifer is also affected.

The unconfined aquifer and a sequence of confined aquifers lie beneath most of the Hanford Site. The unconfined aquifer is generally located in the unconsolidated to semiconsolidated Ringold and Hanford formation sediments that overlie the basalt bedrock. Where it is below the water table, the coarse-grained Hanford formation makes up the most permeable zones of the unconfined aquifer system. The basalt confined aquifers are composed of the brecciated tops of basalt flows and sedimentary interbeds located between basalt flows of the Columbia River Basalt Group.

The saturated thickness of the unconfined aquifer on the Hanford Site is greater than $61 \mathrm{~m}$ in some areas but pinches out along the flanks of the basalt ridges. Depth to the water table ranges from less than $0.3 \mathrm{~m}$ near the Columbia River to more than $106 \mathrm{~m}$ near the 200 Areas. Perched water-table conditions have been encountered in sediments above the unconfined aquifer in the 200West Area (Airhart 1990; Last and Rohay 1993) and in irrigated offsite areas east of the Columbia River (Brown 1979).

Ground water in the unconfined aquifer at Hanford generally flows from recharge areas in the elevated regions near the western boundary of the Hanford Site toward the Columbia River. The Columbia River is a discharge zone for the unconfined aquifer on both sides of the Columbia River. The Yakima River lies southwest of the Hanford Site and is generally regarded as a source of recharge to the unconfined aquifer in the southern part of the Site and in the Richland area. Areal recharge from precipitation falling on the Hanford Site is highly variable both spatially and temporally depending on climate, soil type, and vegetation.

\subsection{Flow System Boundaries}

The unconfined aquifer system at the Hanford Site is bounded by the Columbia River on the north and east, and by the Yakima River and basalt ridges on the south and west. These 
physical flow system boundaries have been defined as either prescribed head or no-flow boundaries in the numerical model. At the Cold Creek and Dry Creek Valleys, the unconfined aquifer extends westward beyond the boundary of the Hanford Site ground-water flow model. Boundaries have been defined across these valleys. An arbitrary boundary has also been defined between Umtanum Ridge and the Columbia River in the northwest corner of the Site. The upper boundary of the unconfined aquifer is usually the water table, which changes position over time. However, the aquifer may be locally confined by fine-grained sediments in a few areas. Flow through the upper boundary includes both natural areal recharge from precipitation and local recharge from liquid waste disposal, irrigation, and artificial recharge activities. Discharge through wells is minor and has not been included in the numerical model. At the Richland city well field there is actually a net recharge because of the input of Columbia River water to recharge basins. The bottom of the unconfined aquifer system is generally defined as the top of basalt. Any recharge or discharge through this boundary is a result of interflow with the underlying confined aquifer system.

\subsubsection{Columbia River Boundary}

The Columbia River flows along the northern and eastern boundaries of the modeled portion of the Hanford Site. Ground water in both the unconfined and confined aquifer systems generally flows toward the river, which is the major discharge area within the Pasco Basin.

The current modeling approach is to represent the Columbia River as a prescribed-head boundary over the depth of the river and as a no-flow boundary from the bottom of the river to the bottom of the aquifer. It is unlikely that ground water in the unconfined aquifer system flows across this boundary because the river is the regional discharge. However, flow across this boundary is possible if a locally confined permeable unit extends beneath the river and is affected by stresses such as pumping. Definitions of hydrogeologic units in the conceptual model are being extended across the river to allow for possible simulations of such a scenario or other scenarios where local flow may pass under the river before discharging to it.

Water levels in many wells near the Columbia River fluctuate in response to changes in river stage. The river stage generally rises and falls daily because releases from upstream dams can change local river levels by up to $3 \mathrm{~m}$ within a few hours. Seasonal changes of about the same magnitude are also observed. River stage fluctuations measured at the 300 Area are only about half the magnitude of those measured near the 100 Areas because of the effect of the pool behind 
McNary Dam, located downstream from the Hanford Site (Campbell et al. 1993). Changes in water-table elevation near the river result primarily from pressure waves transmitted through the unconfined aquifer. However, some water also moves into the aquifer from the river during high river stage resulting in "bank storage" effects. Hydrographs showing the influence of the river stage on the unconfined aquifer at various locations along the Columbia River are presented by Newcomb and Brown (1961), Jensen (1987), Liikala et al. (1988), Schalla et al. (1988), Fruland and Lundgren (1989), Luttrell et al. (1992), McMahon and Peterson (1992), and Campbell (1994). For a general sitewide model, daily and seasonal changes in the river stage resulting from releases from upstream dams can be ignored, and a time-averaged river stage can be used for the prescribed-head value at the river.

Measurements of actual ground-water flux to the Columbia River would be extremely valuable for model calibration. However, because of the large flow of the Columbia River compared to the contribution from ground water, measurements of the relatively small flow rate changes expected to occur along the Hanford Reach are not feasible with any known technology. Estimates of ground-water discharge to the Columbia River have been made in past studies. Luttrell et al. (1992) applied a flow net analysis to calculate discharge in the area of the old Hanford Townsite. They estimated $6.6 \times 10^{6} \mathrm{~m} / \mathrm{yr}$ discharge to about a 1-km length of the river. An earlier estimate of $2.7 \times 10^{6} \mathrm{~m}^{3} / \mathrm{yr}$ for the same area was based on the sitewide flow model (Prater et al. 1984). In comparison, the average annual Columbia River flow is about $1.06 \times 10^{11} \mathrm{~m} 3 / \mathrm{yr}$.

\subsubsection{Yakima River Boundary}

The Yakima River borders the southeastern corner of the modeled area for a distance of approximately $25 \mathrm{~km}$. This includes the western edge of the southern end of the Hanford Site and the western edge of the city of Richland. The Yakima River has usually been represented by a prescribed-head boundary in previous models (Jacobson and Freshley 1990). Because the water levels in the river are higher than the heads within the adjacent aquifer, the river is a potential source of recharge. The recharge rate is controlled by the hydraulic conductivity of sediments adjacent to the river and the head difference between the river and aquifer. However, the recharge at this boundary is highly uncertain because of a lack of wells and a corresponding lack of information concerning hydraulic properties and water-level elevations near the river. This causes uncertainty in 
the model predictions of ground-water flow within the area between the Yakima and Columbia Rivers, an area which is becoming increasingly important as commercial development immediately south of the Hanford Site boundary continues.

As part of a study of ground-water chemistry of the Pasco Basin (Ebbert et al. 1993), the U.S. Geological Survey found evidence that the Yakima River recharges the unconfined aquifer in the reach adjacent to the Hanford Site. This conclusion was based on a comparison of the chemical composition of river water, ground water from a well completed in the Saddle Mountains Basalt, and ground water from an offsite well completed in the unconfined aquifer (Ringold Formation) near the river.

To help define aquifer behavior in the vicinity of the Yakima River, river-stage monitoring has been conducted at a location just below Horn Rapids Dam. As reported in Thorne et al. (1993), water levels were continuously monitored at well $699-$ S24-19 for both the unconfined aquifer system and the basalt confined aquifer system. As shown in Figure 2.2, water levels at this well do not show a direct response to changes in river stage. However, the water level of the unconfined aquifer interval does respond to the filling of a canal (the Horn Rapids Ditch) between the well and the river.

The section of the Yakima River below Horn Rapids Dam flows through flood plain sediments that consist of moderately permeable stream channel deposits within fine-grained overbank and oxbow lake deposits. In this area, the unconfined aquifer may be somewhat isolated from the river by these fine-grained deposits near the river. Examination of drilling logs for private wells near the river shows that there is often fine-grained material near the water table, which sometimes acts as a locally confining unit. After water-bearing sediments are encountered, the water level in the well rises into the depth interval corresponding to the fine-grained material. The presence of low-permeability sediments near the river would also explain the lack of water-level response to the river stage at well 699-S24-19. However, because this well responds to filling of the canal, which is closer to the well, it is likely that the low-permeability sediments do not extend to the canal location. The lack of response could also be explained by recent silt deposits in the bed of the river. 


\subsubsection{Cold Creek Valley}

The boundary of the model region crosses the Cold Creek Valley at the northwestern corner of the Hanford Site. This is an area where the model boundary does not coincide with a physical boundary of the unconfined aquifer flow system. The unconfined aquifer sediments extend into the valley and are a conduit for recharge to the Hanford Site aquifer system. Actual recharge quantities from Cold Creek Valley are not known. Jacobson and Freshley (1990) used a prescribed-flux boundary with an assumed recharge of about $9100 \mathrm{~m}^{3 / \mathrm{d}}$ at the mouth of the Cold Creek Valley in two of the cases they ran for the inverse calibration model. The result in both cases was unrealistically high head values calculated by the model in the vicinity of Cold Creek Valley. Therefore, either the prescribed recharge at this boundary was too large or transmissivities in the area were set too low. Better results were obtained by Jacobson and Freshley (1990) when using a prescribed-head boundary. However, uncertainty in the transmissivity distribution remains, because it is not known if the recharge calculated by the model at this boundary, which depends on the hydraulic gradient across the boundary and the transmissivity of the adjacent model elements, is realistic.

A hydraulic test was conducted at well 699-43-104 during 1994. This test resulted in a relatively low transmissivity estimate of $25 \mathrm{~m} 2 / \mathrm{d}$ and an equivalent hydraulic conductivity of about $2 \mathrm{~m} / \mathrm{d}$. However, these values may not be representative of the bulk of Cold Creek Valley sediments.

\subsubsection{Interflow with the Basalt Confined Aquifer System}

Flow-system boundaries are formed by the contact between the unconfined aquifer system and basalt. At places where basalt subcrops above the water table, this contact may form either a perimeter boundary or an island of basalt within the model area. The basalt contact also forms the lower boundary of the unconfined aquifer system except in some areas where a mud unit may underlie the aquifer directly over basalt.

Some of the perimeter basalt contact boundaries (i.e., Rattlesnake Mountain) may be recharge boundaries because of the infiltration of precipitation runoff and spring discharge from the upper slopes. There is also a potential for interflow (recharge or discharge) between the basalt confined aquifer system and the unconfined aquifer system at the lower boundary. Over most of 
the Site, the amount of interflow is thought to be small because of the low hydraulic conductivity of the rock separating the two aquifer systems. However, areas of increased vertical flow have been previously identified in the Gable Mountain and Gable Butte area on the basis of chemistry data (Graham et al. 1984; Jensen 1987). Hydraulic head data for the uppermost confined basalt aquifer also indicates the potential for water to discharge from this aquifer upward into the unconfined system in the northeastern part of the Hanford Site (Spane and Raymond 1993; Spane and Webber 1995). Figure 2.3 shows a comparison of observed hydraulic heads for the two aquifer systems and delineates areas of upward and downward hydraulic gradient.

Another potential area of increased vertical flow between aquifers is in the vicinity of the Yakima River horn, where the river has incised the upper basalt confining layers. A recent investigation (WHC 1993) identified a bimodal distribution of chloride in the unconfined aquifer in this area. Some wells yield concentrations of less than $10 \mathrm{mg} / \mathrm{L}$ and other wells have greater than $20 \mathrm{mg} / \mathrm{L}$. The lower concentration ground water is chemically similar to water from Rattlesnake Hills springs, suggesting that this ground water comes from subsurface discharge from the underlying basalts. The ground water with higher chloride concentrations may come from infiltration of surface flow, which is subject to greater evaporation.

Interflow between the unconfined and basalt confined aquifer systems is not accounted for by the current numerical model. The rate of ground-water movement between the confined and unconfined aquifer systems is difficult to quantify. Therefore, it is not known if ignoring this contribution has a significant effect on the accuracy of the ground-water flow model. Differences in ground-water chemistry and temperature offer two possible methods for identifying areas of enhanced interflow and possibly quantifying flow rates. The possible use of temperature logs for this purpose has been preliminarily investigated and results are presented in Thorne et al. (1994).

\subsection{Recharge and Discharge}

Natural recharge to the unconfined aquifer system occurs from infiltration of runoff from 1) elevated regions along the western boundary of the Site, 2) infiltration of spring water that originates from the basalt aquifer system, and 3) infiltration of precipitation falling across the Hanford Site. Some recharge also takes place along the Yakima River, in the southern end of the Site. Since the start of Hanford operations in the mid-1940s, the estimated recharge from these 
natural sources has been less than the artificial recharge from waste-water disposal facilities. However, during the past 5 years, most production activities on the Hanford Site have been curtailed resulting in a decrease in waste-water disposal. Currently the volume of artificial recharge is similar to the volume of natural estimated recharge (Fayer and Walters 1995).

The Columbia River is the principal discharge area for the unconfined aquifer system. A few wells produce water from the unconfined aquifer on the Hanford Site (Figure 2.4). However, the total volume produced is relatively small and is not expected to be a significant discharge component on the sitewide scale. The supply wells serving the 400 Area have the highest withdrawal rates, which average about $500 \mathrm{~m} 3 / \mathrm{d}$.

\subsubsection{Natural Areal Recharge}

Natural areal recharge from precipitation falling on the Hanford Site is highly variable both spatially and temporally, ranging from near zero to more than $100 \mathrm{~mm} / \mathrm{yr}$ depending on climate, vegetation, and soil texture (Gee et al. 1992; Fayer and Walters 1995). Areas with shrubs and fine-textured soils like silt loams tend to have low recharge rates, while areas with little vegetation and coarse-textured soils, such as dune sands, tend to have high recharge rates. Recharge is also generally higher near the basalt ridges because of greater precipitation and runoff. Past estimates of recharge have been summarized in earlier status reports (Thorne and Chamness 1992; Thorne et al. 1993). To support the three-dimensional model, a natural recharge map (Figure 2.5) was developed by Fayer and Walters (1995). The distributions of soil and vegetation types were mapped first. A recharge rate was then assigned to each combination on the basis of data from lysimeters, tracer studies, neutron probe measurements, and computer modeling. Estimated recharge rates for 1992 were found to range from 2.6 to $127 \mathrm{~mm} / \mathrm{yr}$ and the total volume of natural recharge from precipitation over the Hanford Site was estimated at $8.47 \times 10^{6} \mathrm{~m} 3 / \mathrm{yr}$. This value is of the same order of magnitude as the artificial recharge to 200 Area waste disposal facilities during 1992 and is about half the volume of discharge to these facilities during 1979 (Fayer and Walters 1995).

\subsubsection{Artificial Recharge}

The large volume of waste water discharged to disposal facilities (Figure 2.6) on the Hanford Site over the past 50 years has significantly affected the ground-water flow system. As shown in Figure 2.7, the volume of artificial recharge has decreased significantly during the past 
10 years and is currently still decreasing (Barnett et al. 1995; Dresel et al. 1995). Until it was taken out of service in 1984, Gable Mountain Pond received the largest volume of discharge on the Hanford Site. Major ground-water mounds have occurred beneath B Pond, Gable Mountain Pond, and U Pond, and have affected sitewide ground-water flow patterns (Bierschenk 1959; Dresel et al. 1995). Waste water is no longer being discharged to U Pond and Gable Mountain Pond, which have been decommissioned and are now dry. Other smaller-volume recharge sources have existed until recently in the 100,200 , and 300 Areas and may affect ground-water flow on a local scale. Currently, the two major artificial recharge sources are B Pond and the 200 Area Treated Effluent Disposal Facility (TEDF). Effluent discharges to TEDF began in April 1995, and averaged from 545 to $817 \mathrm{~m} 3 / \mathrm{d}$ during the first 2 months. Discharge volumes averaged about $1909 \mathrm{~m}^{3} / \mathrm{d}$ during June through September, and have been averaging from 2074 to $2290 \mathrm{~m} 3 / \mathrm{d}$ since September. Eventually, discharge to B Pond is planned to be eliminated. After that time, all tritiated water will be disposed to the State-Approved Land Disposal Site (SALDS), and clean water will be disposed to TEDF. Additional information on waste-water discharge is available in the Hanford Site Ground Water Protection Management Plan (Barnett et al. 1995).

The city of Richland infiltration ponds, agricultural and lawn irrigation, and ground disposal of waste water at a potato-processing plant are other sources of artificial recharge that may affect ground-water flow in the north Richland area and in the southern part of the Hanford Site (Liikala 1994).

\subsection{Hydrogeologic Framework}

Understanding the lateral extent and relationships between the hydrogeologic units found in different parts of the Hanford Site is crucial to understanding the movement of ground-water contaminants and for constructing accurate contaminant transport models. For example, it is important to determine whether or not fine-grained units found in the eastern and western portions of the Site directly overlap one another in the central part of the basin to form a continuous aquitard.

The steps involved in developing the hydrogeologic framework were 1) identify the minimum number of distinct hydrogeologic units to adequately define the Hanford unconfined aquifer, 2) determine the geologic contacts between these layers at as many wells as possible across 
the Site, and 3) use the three-dimensional visualization software package EarthVision(c) to transform this data set into two-dimensional grids (layers) for each of the units. The two-dimensional grids are combined into a three-dimensional model of the hydrogeologic structure when they are input to the three-dimensional ground-water flow model.

Identification of Hydrogeologic Units The movement of ground water within the aquifer is controlled by the hydraulic conductivity, which is closely related to the sediment texture. Texture is a function of the grain-size distribution, sorting, and consolidation/cementation. Sediments were differentiated into either coarse or fine texture groups, then split into individual hydrogeologic units based on stratigraphic position, color, and distinctive markers such as ash horizons. Normally, identification of geologic units also uses depositional environment and relative time of deposition to define contacts between units. Because we are interested in the movement of ground water, the important geologic information is related to the movement of ground water. Figure 2.8 shows a comparison of a geologic stratigraphic column and the one developed here. The two are very similar, but it is important to clarify the difference. An example is the lower part of the upper Ringold as defined by Lindsey (1992), which in some places becomes progressively more sandy with depth. Where sand is the only (or overwhelmingly dominant) grain size, it was grouped with the underlying coarse-grained Unit 5. Although this may not conform to standard geologic classification, the sandy base of the upper Ringold is probably hydraulically connected with and hydrologically similar to Unit 5, with which it is grouped in this report. Generally, sands were grouped with sandy gravels, and silt was grouped with clay, assuming similar hydraulic conductivities. Nine distinct hydrogeologic units were identified above the top of basalt.

Others have previously identified similar units in studies focused on operational areas. Individual reports on the 100 Areas (Peterson 1992; Hartman and Lindsey 1993; Lindberg 1993a,b; Lindsey and Jaeger 1993), the 200 Areas (Connelly et al. 1992a,b), and the 300 Area (Swanson 1992) have been released in the past 5 years, but few geologic studies have addressed the regions of the Hanford Site lying between these operational areas. The nine hydrogeologic units identified for this conceptual model are similar to those in the reports above, with some differences in the location of unit contacts in places as discussed above and shown in Figure 2.8.

(c) EarthVision is a registered trademark of Dynamic Graphics, Inc., Alameda, California. 
Determination of Geologic Contacts Data from 426 wells across the Hanford Site have been used to define hydrogeologic units based on textural composition. Top of basalt was identified in an additional 150 wells. The areal distribution of these wells is shown in Figure 2.9. Data used in defining hydrogeologic units included well logs, downhole geophysical logs, particle size analyses, calcium carbonate content, and geologic interpretations from other reports. Once the distribution of each of the hydrogeologic units was understood, a line showing the estimated extent of each unit was generated, i.e., lines showing where each unit reaches zero thickness. These "extent lines" were made as accurate as possible on the west and south sides of the Hanford Site, where the units pinch out on the basalt highs near the edge of the model. To the north and east, however, the numerical model extends only as far as the Columbia River and the basalt highs are much further away than that. Consequently, in those areas the extent lines were drawn to some arbitrary distance beyond the river to create an appropriate thickness for each unit at the edge of the model beneath the river. The gridding program interpolated the data set beyond the actual lateral extent of the unit and the model boundary was used to truncate the interpolated two-dimensional grids, where necessary.

The uppermost basalt flow was used as the bottom of the hydrogeologic framework because it forms the base of the Hanford unconfined aquifer. Figure 2.10 shows the top of basalt elevation. Unit 9 lies directly above basalt at the bottom of the unconfined aquifer system. This unit consists of fluvial sand and gravel and generally correlates to Lindsey's Unit A (basal Ringold). Unit 9 is found in the deeper parts of the basin, pinching out on (or eroded from) the limbs of the basalt anticlines. Figure 2.11 shows an isopach map of Unit 9 within the Hanford Site, and Figure 2.12 shows the distribution of wells where this unit was identified. In most places, Unit 9 is overlain by Unit 8. Unit 8 is equivalent to Lindsey's Lower Mud Sequence (the lower Ringold and part of the basal Ringold) and forms an aquitard across much of the Site. The mud in this unit is often described as blue or green, sticky clay, and frequently includes a white "ash" that may correspond to the ash in the lower Ringold in Bjornstad (1984). As shown in the isopach map (Figure 2.13), Unit 8 is relatively extensive across the Site. Figure 2.14 shows the locations of wells where this unit was identified.

Units 7 and 6 have more complex relationships and are more difficult to classify. During the time these units were deposited, the river channel apparently shifted position more often, depositing a complex pattern of overbank and mainstream deposits. To simplify the conceptual model, Unit 7 is defined as the coarse-grained sediments immediately overlying Unit 8. 
Figure 2.15 shows an isopach map of this unit. The locations of wells where Unit 7 is identified are shown in Figure 2.16. Unit 6 is defined as the sequence of mostly fine-grained sediments with some interbedded coarse-grained sediments overlying Unit 7 and underlying Unit 5. Figure 2.17 shows an isopach map of Unit 6 . The locations of wells where Unit 6 is identified are shown in Figure 2.18. Unit 7 generally corresponds to Lindsey's Units B and D, while Unit 6 corresponds to Unit $C$ and the unnamed mud layers.

Where coarse-grained Unit 7 is not present; Units 6 and 8 cannot usually be distinguished. In these cases, the fine-grained sediments are usually grouped into Unit 8 . Likewise, where finegrained Unit 6 is not present, Units 5 and 7 cannot be distinguished and the coarse-grained sediments are grouped into Unit 5 . Unit 5 corresponds to the fluvial, coarse-grained sediments of Lindsey's Unit E (middle Ringold) (see Figure 2.8). This unit is quite thick in the western portion of the Site where Units 6 and 7 are not recognized. In many parts of the Site, the water table is presently found in Unit 5. Figure 2.19 shows an isopach map of Unit 5. The locations of wells where the unit is identified are shown in Figure 2.20.

Overlying Unit 5 is Unit 4, a fine-grained fluvial and lacustrine unit that corresponds to Lindsey's Upper Ringold Unit. Unit 4 has been eroded from large portions of the Site. Figure 2.21 shows an isopach map of Unit 4. The locations of wells where Unit 4 is identified are shown in Figure 2.22. In the eastern part of the area north of Gable Mountain, distinction between the fine-grained Unit 6 and the probable base of Unit 4 cannot be made, and the sediments are all grouped into Unit 6.

Units 2 and 3 correspond to the early "Palouse" soil and the Plio-Pleistocene unit, respectively. Unit 3 is a buried soil horizon containing caliche and side-stream basaltic gravels. It is only recognized in the western part of the basin (Figure 2.23). The locations of wells where Unit 3 was identified are shown in Figure 2.24. The caliche developed on the top of the eroded Ringold sediments and has a low hydraulic conductivity, while the side-stream gravels have a high conductivity. There is only one small area south of the 200-West Area where Unit 3 , as the sidestream gravels, intersects the water table. Unit 2 is a small pocket of fine-grained sediments that have been interpreted as eolian silt. Figure 2.25 shows an isopach map of Unit 2. The locations of wells where Unit 2 was identified are shown in Figure 2.26. Unit 2 does not intersect the water table. 
Unit 1 is the Hanford formation, which is generally a high permeability sand and gravel unit that covers most of the Hanford Site. In most areas where Unit 1 is below the water table, the sediments are gravels or coarse sands. The finer-grained sand- and silt-dominated facies are mostly above the water table within the boundaries of the Hanford Site. For this study, the surficial sand dunes have been included with Unit 1. Figure 2.27 shows an isopach map of Unit 1. The locations of wells where Unit 1 is identified are shown in Figure 2.28.

Lying beneath the gravels of the Hanford formation in the central portion of the Hanford Site are the sand and gravel deposits commonly called the "pre-Missoula gravels" (PSPL 1982). These sediments have been grouped with the Hanford formation (Unit 1) for the following reasons: 1) the pre-Missoula gravels cannot be readily distinguished from the Hanford formation in most driller's or geologist's logs, 2) there are no known hydraulic property data for the pre-Missoula gravels, although its properties probably lie between the younger Hanford gravel-dominated facies and older sandy gravel of Unit 5, and 3) the pre-Missoula gravels are above the water table except in some areas near the Hanford Townsite and near the solid waste landfill in the center of the Hanford Site. Therefore, they do not present a primary pathway for ground-water movement.

Transformation of Data Set into Grids EarthVision is a software package developed to assist geologists in interpreting geologic data and provide a three-dimensional visualization. The data set developed as discussed above was run through the EarthVision software to develop the twodimensional grids for each unit. The software also allowed visual inspection of the ensuing grids and their modification as necessary. Data were recorded so that the real value for a contact was given if the unit was present. If the contact was uncertain, the well did not penetrate deeply enough, or the contacts had not been determined yet, the data point was flagged. A different flag was used when the unit did not occur at that well. Several problems occurred during this stage of model development which are discussed in more detail below.

One of the problems encountered was the wide variety in accuracy and/or descriptions of sediments recorded by drillers. A majority of the wells on the Site were logged only by the driller. Where there was doubt as to the veracity of the geologic contact for a particular well (e.g., a thick mud layer was missing in one well and present in all those nearby), the suspect contact(s) were flagged in such a way that the gridding software would ignore that well's value for only that contact. This technique allowed the use of other contacts picked from the wells that were believed to be most 
accurate. It also helped smooth the grids somewhat by removing data that looked like "fliers" from consideration in the gridding process.

Another difficulty occurred because geologic layers could be simulated as either grading smoothly from one texture to another, or as an abrupt textural change that occurs from sediments being deposited on an erosional surface. However, the software program could not accommodate both of these processes occurring in different places in the same hydrogeologic unit. The effects of this are most noticeable in the thickness distribution of an affected unit. A geologic unit pinches out to zero thickness on underlying units in a depositional environment, whereas it may reach zero thickness abruptly as a cliff if the unit had been eroded. In this conceptual model, the unit edges pinch out only. This causes some distortion of the real hydrogeologic thickness in places, but is thought to have minor effects on the overall ground-water modeling.

Finally, the program was allowed to interpolate between data points. This interpolation may not exactly match other interpretations based on an understanding of geologic processes. It was not possible to constrain the two-dimensional gridding process to make it exactly fit our current geologic understanding of the Site. However, spot checks of where the Ringold Formation intersects the water table, indicate the computer interpolation is not greatly different from other interpretations.

\subsection{Hydraulic Properties}

Hydraulic properties including both horizontal and vertical hydraulic conductivity $\left(\mathrm{K}_{\mathrm{h}}\right.$ and $\mathrm{K}_{\mathrm{v}}$ ), storativity $(\mathrm{S})$, and specific yield $\left(\mathrm{S}_{\mathrm{y}}\right)$ are key components of the conceptual model. To support three-dimensional numerical modeling, the distribution of each of these parameters must be specified for each hydrogeologic unit. Hydraulic conductivity controls the rate of water flow through a unit thickness of the aquifer at a given hydraulic gradient. Storativity and specific yield determine the change in water-table elevation that will occur in response to a change in the volume of water stored in the aquifer.

Hydraulic property data for the Hanford Site unconfined aquifer have been derived mainly from aquifer pumping tests and, in a few cases, from laboratory permeameter tests. These results have been documented in dozens of published and unpublished reports over the past 50 years. A 
summary of available data for the unconfined aquifer was provided in DOE (1988) and an updated summary was provided in Thorne and Newcomer (1992) together with an evaluation of selected pumping test analyses. Additional tests have been conducted both to support the three-dimensional model and to support other Hanford Site projects. Some of the recent tests are documented in status reports on the development of the three-dimensional conceptual model (Thorne and Chamness 1992; Thorne et al. 1993, 1994).

During 1995, a pumping test was conducted by the city of Richland on a new water supply well located near Wellsian Way in the southern part of Richland. Data were collected from a nearby observation well and analyzed to provide an additional measurement of hydraulic properties for the Hanford formation (Unit 1) in this area. The test analysis and results are described in detail in Appendix A.

Newcomb and Strand (1953) analyzed the growth of ground-water mounds beneath liquid disposal facilities in both the 200-West Area and 200-East Area between 1948 and 1953 to estimate hydraulic properties for these areas. Recent decreases in disposal volumes have caused a decrease in these mounds that has been analyzed to obtain additional hydraulic property information. Details of the analysis of the mound dissipation are provided in Appendix B.

\subsubsection{Hydraulic Conductivity of Hydrogeologic Units}

Hydraulic conductivity values for sediments composing the unconfined aquifer system range from less than $10^{-4} \mathrm{~m} / \mathrm{d}$ for some mud units to about $10^{6} \mathrm{~m} / \mathrm{d}$ for coarse gravel flood deposits. The sand and gravel facies of the Ringold Formation are about 10 to 100 times less permeable than the coarse sediments of the overlying Hanford formation (DOE 1988). The Ringold Formation also contains relatively extensive layers of fine grained, low permeability sediments such as silt or clay.

Most pumping test analyses result in estimates of aquifer transmissivity ( $T$ ), which, for a vertically homogeneous aquifer, is the product of $\mathrm{K}_{\mathrm{h}}$ and aquifer thickness (b). However, for an aquifer composed of $\mathbf{n}$ layers having different hydraulic conductivities, transmissivity is given by

$$
\mathrm{T}=\sum_{\mathrm{i}=1}^{\mathrm{n}} \mathrm{K}_{\mathrm{i}} \mathrm{b}_{\mathrm{i}}
$$


where: $\mathrm{K}_{\mathrm{i}}=$ horizontal hydraulic conductivity of layer $\mathrm{i}$

$b_{i}=$ thickness of layer $I$.

A listing of available transmissivity data obtained from pumping tests in the unconfined aquifer system is provided in Appendix C. Where possible, the thickness of the tested aquifer facies has been noted and used to calculate an equivalent $K_{h}$. Figure 2.29 shows the distribution of the tested wells across the Hanford Site and also indicates the main geologic unit tested. The data listed in Appendix $\mathrm{C}$ include 36 single well pumping tests and 3 multiple well pumping tests that pertain to the Hanford formation (Unit 1). Thirty-seven single well pumping tests and 12 multiple well pumping tests pertain to Ringold Formation sand and gravel units (Units 5, 7, and 9). An additional 32 single well pumping tests, 7 multiple well pumping tests, and 2 specific capacity tests are included for which the tested hydrogeologic unit has not been defined. The quality of these results is affected by both aquifer conditions and analysis procedures and varies widely (Thorne and Newcomer 1992). Slug tests have also been conducted at several Hanford Site wells. However, because many of the single well slug test results are considered inaccurate, they have not been listed in Appendix $C$ or used to determine hydraulic properties for the conceptual model. Multiple well slug tests have been conducted at a few wells in conjunction with multiple well pumping tests. Because of vertical aquifer heterogeneity, and because most of the tested wells at Hanford partially penetrate the unconfined aquifer, it is sometimes difficult to determine the aquifer thickness that should be used in calculating hydraulic conductivity from the test results.

As discussed in earlier status reports (Thorne and Chamness 1992; Thorne et al. 1993), the current approach for the three-dimensional conceptual model is to assign an areal distribution of $\mathrm{K}_{\mathbf{h}}$ to the most significant permeable units that form the upper part of the unconfined aquifer system. Most ground-water flow and contaminant transport takes place in this part of the aquifer system. Single values of $K_{h}$ are assigned to mud-dominated units and to deeper permeable units.

The uppermost permeable unit for most of the model region is either Unit 1 or Unit 5. Units 7 and 9 represent deeper permeable units. The hydraulic conductivity of Unit 1 generally ranges from about 1 to $1,000,000 \mathrm{~m} / \mathrm{d}$ and is much higher than any of the other units that compose the unconfined aquifer system. Therefore, where it is present below the water table, this unit usually provides the dominant flow path within the aquifer. Figure 2.30 outlines areas of the Hanford Site where the water table was estimated to lie within the Ringold Formation during 1993. Unit 1 
consists of sand and gravel of the Hanford formation and the pre-Missoula gravel deposits. Extensive fine-grained facies of the Hanford formation are not found below the water table within the model region. In the vicinity of B Pond, the saturated portion of the Hanford formation is composed of muddy sandy gravels that probably represent the lower limit of hydraulic conductivity for Unit 1. Aquifer tests (Thorne et al. 1993) indicate that the minimum $K_{h}$ is about $1 \mathrm{~m} / \mathrm{d}$ and the minimum $K_{v}$ is about $0.02 \mathrm{~m} / \mathrm{d}$ for Unit 1 . The maximum measured value of $K_{h}$ for Unit 1 on the Hanford Site is about 10,000 $\mathrm{m} / \mathrm{d}$ (Thorne and Newcomer 1992; DOE 1988). However, the maximum hydraulic conductivity that can be measured by an aquifer test is limited by the well efficiency and the flow rate that can be pumped with available equipment. The upper limit of $\mathrm{K}_{\mathrm{h}}$ for coarse gravel flood deposits of Unit 1 is probably greater than $1,000,000 \mathrm{~m} / \mathrm{d}$ based on inverse numerical modeling. Maximum $\mathrm{K}_{\mathrm{v}}$ is unknown, but may approach the value for $\mathrm{K}_{\mathrm{h}}$ in relatively clean gravel zones where stratified layers of finer grained material are not present.

Units 5, 7, and 9 are all within the Ringold Formation and consist of sand to muddy sandy gravel with varying degrees of consolidation and/or cementation. Unit 5 is the most widespread unit within the unconfined aquifer and is found below the water table across most of the model region. Hydraulic conductivities of Units 5, 7, and 9 determined from aquifer tests vary within the range of about 0.1 to $200 \mathrm{~m} / \mathrm{d}$. Because these units are hydrologically similar, they were grouped together in areas where the intervening mud units do not exist. A few aquifer tests suggest vertical anisotropy is in the range of 0.01 to 0.1 . Therefore, the range of $\mathrm{K}_{\mathrm{v}}$ is estimated at about 0.001 to $20 \mathrm{~m} / \mathrm{d}$.

Mud-dominated units within the unconfined aquifer system include Unit 4, also known as the upper Ringold fines; Unit 6, which is a composite of intercalated mud and sand and gravel layers; and Unit 8, which is an extensive lower Ringold mud unit. Hydraulic conductivity of these units is generally about 2 to 5 orders of magnitude less than that of the permeable sand and gravel units. Therefore, the mud units are essentially aquitards and are not expected to transmit significant quantities of water or contaminants in the horizontal direction. They are most significant in slowing the vertical migration of contaminants and influencing vertical head distributions. Therefore, the values of $\mathrm{K}_{\mathrm{v}}$ assigned to mud units are probably more important than the assigned values of $\mathrm{K}_{\mathrm{h}}$.

Hydraulic test results for mud-dominated units are listed in Table 2.1. These few tests yielded hydraulic conductivity $(\mathrm{K})$ values of 0.0003 to $0.09 \mathrm{~m} / \mathrm{d}$. Some of the results are from well tests and some are from laboratory tests. Because of a tendency to complete wells only in zones 
Table 2.1. Hydraulic Test Results for Mud-Dominated Units

\begin{tabular}{|c|c|c||}
\hline $\begin{array}{c}\text { Hanford Well } \\
\text { Number }\end{array}$ & $\begin{array}{c}\text { Hydraulic } \\
\text { Conductivity (K) } \\
(\mathrm{m} / \mathrm{d})\end{array}$ & Hydrogeologic Unit \\
\hline $299-\mathrm{W} 7-9$ & 0.09 & Unit 4 (vadose) \\
\hline $699-20-39$ & $<0.06$ & Unit 6 \\
\hline $699-84-35 \mathrm{~A}$ & 0.03 & Unit 6 \\
\hline $699-41-40$ & 0.0003 & Unit 4 \\
\hline
\end{tabular}

that are likely to produce some water, these values may represent the higher range of $\mathrm{K}_{\mathrm{h}}$ for the mud units. Test results for Unit 6 indicate that this unit has higher $\mathrm{K}_{\mathrm{h}}$ than Unit 4. This is expected because of the sand and gravel layers included in Unit 6 . Unit 8 is expected to have hydraulic conductivity similar to Unit 4 . Freeze and Cherry (1979) give a hydraulic conductivity range of 0.001 to $1 \mathrm{~m} / \mathrm{d}$ for silt and loess, and as low as $10^{-7} \mathrm{~m} / \mathrm{d}$ for clay. This range is partially based on a compilation of data by Davis (1969).

\subsubsection{Storativity and Specific Yield}

Storativity and specific yield can be calculated from multiple well pumping tests and multiple well slug interference tests (Spane 1993, 1994). Storativity and specific yield results from the relatively few multiple well tests conducted on the Hanford Site are listed in Table 2.2. The average specific yield from these tests was 0.15 . However, some of these estimates are highly uncertain because of the effects of nonideal test conditions, such as partially penetrating wells and aquifer heterogeneity. Such conditions generally have a more significant effect on the determination of storage properties than on the determination of transmissivity. Moench (1994) demonstrated that these conditions can affect specific yield values calculated from type-curve analysis of aquifer pumping tests, and usually result in the calculated values being low.

Specific yield can also be calculated by measuring the change in saturated aquifer volume in response to the injection or withdrawal of a known volume of ground water. This method was applied to the decreasing ground-water mound that occurred beneath the 200-West Area between 
Table 2.2. Multiple Well Test Results

\begin{tabular}{||l|l|l|l||}
\hline Well & Storativity (S) & Specific Yield (Sy) & Hydrogeologic Unit Tested \\
\hline 199-K-10 & 0.00007 & 0.04 & 5 \\
\hline $299-$ W10-13 & 0.009 & - & 5 \\
\hline $699-S 27-E 9 A$ & 0.013 & 0.37 & 1,5 \\
\hline $699-S 22-E 9 B$ & 0.005 & 0.02 & $1,5,7$ \\
\hline $699-S 14-20 \mathrm{C}$ & 0.005 & 0.25 & Unknown \\
\hline $699-26-35 \mathrm{C}$ & 0.0015 & - & 1 \\
\hline $699-31-53 \mathrm{~B}$ & - & 0.38 & 5 \\
\hline $699-32-72$ & - & 0.05 & 5 \\
\hline $699-36-61 \mathrm{~A}$ & - & 0.05 & 5 \\
\hline $699-37-82 \mathrm{~A}$ & 0.02 & 0.18 & 5 \\
\hline $699-42-40 \mathrm{C}$ & 0.02 & - & Unknown \\
\hline $699-42-42 \mathrm{~B}$ & 0.00003 & - & Unknown \\
\hline $699-43-89$ & - & 0.05 & Unknown \\
\hline $699-47-35 \mathrm{C}$ & 0.002 & 0.15 & 9 \\
\hline $699-48-77 \mathrm{C}$ & 0.001 & - & Unknown \\
\hline $699-55-50 \mathrm{~A}$ & - & 0.2 & 1 \\
\hline $699-62-43 \mathrm{~B}$ & - & 0.06 & 1 \\
\hline & & & \\
\hline
\end{tabular}

1985 and 1995 (Appendix B). The calculated specific yield was 0.17, which is higher than the 0.11 value calculated by Newcomb and Strand (1953) when they analyzed the growth of ground-water mounds beneath liquid disposal facilities in both the 200-West Area and 200-East Area between 1948 and 1953. The accuracy of results from both these analyses is uncertain because the analyses assume that steady-state conditions have been reached at the end of the analyzed period. Small head changes on the fringes of the mound are also difficult to measure and may have a significant impact because of the large area they cover. 
Specific yield for Unit 1 is estimated to range from about 0.1 to 0.3 and is expected to be higher for coarse, well sorted gravel than for poorly sorted mixtures of sand and gravel. Storativity is estimated to range from 0.0001 to 0.0005 . Specific yield is estimated to range from 0.05 to 0.2 for the generally poorly sorted sediments of Units 5,7 , and 9 . Storativity is estimated to range from 0.0001 to 0.001 for these units.

\subsection{Hydraulic Heads}

Hydraulic head information is important for determining ground-water flow direction and velocity. Head measurements are also needed to establish initial conditions for ground-water flow modeling and for model calibration.

Water levels have been measured on at least an annual basis using a sitewide well network since the 1940s. More than 600 wells are currently measured each year to determine the hydraulic head distribution for the unconfined aquifer on the Hanford Site and adjacent areas. Results of the 1994 measurements are presented in Dresel et al. (1995). Additional water-level data for the North Richland area are provided in Liikala (1994). The annual water-level measurements provide an extensive database that can be used to define initial head conditions for numerical modeling and for a comparison of modeling runs with historical data.

Prior to the mid 1980s, hydraulic heads increased by more than $13 \mathrm{~m}$ in some areas of the Hanford Site in response to waste-water disposal activities. Before waste-water disposal operations began, the uppermost aquifer was almost entirely within the Ringold Formation, and the water table extended into the Hanford formation at only a few locations near the Columbia River (Newcomb and Strand 1953). However, waste-water discharges have caused the water-table elevation to rise into the Hanford formation in the vicinity of the 200-East Area and in a wider area near the Columbia River. Figure 2.30 outlines areas of the Hanford Site where the water table was estimated to lie within the Ringold Formation during 1993. Water levels have begun to decrease over most of the Hanford Site during the last several years because of decreases in waste-water discharge (Dresel et al. 1995).

Most of the wells in the current unconfined aquifer monitoring network are completed in the upper part of the aquifer, within $7 \mathrm{~m}$ of the water table. Most of the wells that were originally open 
to a greater depth interval were reconfigured in the early 1980s. Additional details concerning the reconfiguration of these wells are provided in a later section on contaminant distributions.

Three-dimensional modeling requires information on the vertical distribution of hydraulic head as well as the areal distribution. Therefore, a listing of selected wells currently completed in the deeper part of the unconfined aquifer and wells with individual piezometers open to different depth intervals was compiled and presented in an earlier conceptual model status report (Thorne et al. 1993). An updated version of this listing is provided in Appendix D. Water levels measured in some piezometer clusters are presented in Table 2.3. Figure 2.31 shows the location of these wells at the Hanford Site. Some of the measurements may be affected by well construction problems. Some of the wells containing several piezometer tubes placed to various depths in a perforated well casing were originally completed by backfilling around the piezometer tubes with sand. Because the sand may not have provided adequate isolation of the individual depth intervals, water level data from this type of piezometer completion are suspect. Other piezometers may be in communication with the well annulus or other isolated intervals.

\subsection{Transport Properties}

To accurately model contaminant transport, parameters including effective porosity, dispersivity, and retardation coefficients must be specified. Longitudinal, transverse, and vertical dispersivity values are needed for a three-dimensional model. Retardation coefficients are not discussed here because they are specific to each contaminant species and may vary depending on geochemical conditions within the aquifer. Information of retardation coefficients for Hanford unconfined aquifer sediments is available in Ames and Serne (1991) and Kaplan and Serne (1995).

\subsubsection{Effective Porosity}

Porosity is defined as the volume of void space divided by the total volume of the soil or rock matrix that contains it. Effective porosity does not include void space that is isolated from ground-water flow and, therefore, may be smaller than the total porosity. The average velocity of a conservative contaminant (non-sorbing and non-decaying) as it moves through an aquifer is equal to the average linear velocity of the ground water, which is inversely proportional to the effective porosity of the aquifer matrix (Freeze and Cherry 1979). Porosity can be determined from 
Table 2.3. List of Selected Wells with Individual Piezometers Open to Different Depth Intervals

\begin{tabular}{||l|l|l|l|l|l||l|l|l||l|l||l|l|l||}
\hline Well & Piezo & DTW & Piezo & DTW & Piezo & DTW & Piezo & DTW & Piezo & DTW \\
\hline 199-H4-15C & S & 9.83 & R & 10.24 & Q & NM & P & NM & & \\
\hline $299-$ W22-24 & T & 72.91 & S & 74.72 & R & 71.71 & Q & 73.36 & P & 74.79 \\
\hline $299-E 23-2$ & O & 97.33 & Q & 97.32 & P & 97.32 & & & & \\
\hline $699-S 12-29$ & Q & 26.98 & P & 26.22 & & & & & & \\
\hline $699-2-33 B$ & Q & 39.72 & P & 39.94 & & & & & & \\
\hline $699-10-E 12$ & Q & 11.46 & P & 22.47 & & & & & & \\
\hline $699-14-28$ & Q & 33.57 & P & 33.52 & & & & & & \\
\hline $699-25-33 B$ & Q & 39.14 & P & 39.11 & & & & & & \\
\hline $699-37-82 B$ & O & NM & S & 52.71 & R & 53.12 & Q & NM & P & NM \\
\hline $699-67-51$ & Q & 38.46 & P & 38.89 & & & & & & \\
\hline $699-69-45$ & O & 27.26 & R & 27.36 & Q & 29.54 & P & 29.12 & & \\
\hline
\end{tabular}

DTW = depth to water (meters below well measuring point).

$\mathrm{NM}=$ not measured.

laboratory measurements on samples of aquifer material or from field tracer tests. For unconfined aquifers, effective porosity can be assumed to be equal to specific yield obtained from multiple-well hydraulic tests.

Laboratory measurements of porosity are available for samples from only a few of the available Hanford Site wells. Recently, 15 samples were collected from 6 wells at the $100 \mathrm{H}$ Area (Vermeul et al. 1995). Porosity ranged from 0.19 to 0.41 and averaged 0.33 for the Ringold Formation and 0.31 for the Hanford formation. Samples from five depth intervals within the Ringold Formation at the 200-West Area were reported by Newcomer et al. (1995). The average porosity ranged from 0.21 to 0.33 and averaged 0.27 . Laboratory porosity measurements are often 
considered unreliable, especially for unconsolidated sediments, because of the difficulty in obtaining undisturbed samples.

A few tracer tests have been conducted within the unconfined aquifer. Bierschenk (1959) reported an effective porosity of 0.10 from a tracer test with fluorescein dye under natural gradient conditions. Single borehole dilution tests, which do not provide information on porosity, were conducted by Graham et al. (1984). An effective porosity of 0.25 was assumed to calculate average ground-water velocity from the measurements. Borehole dilution tests and a two-well tracer test were conducted in the 200-West Area (Newcomer et al. 1995) under natural gradient conditions. However, porosity could not be determined from the two-well tracer test because the gradient was not well defined.

Porosity can also be estimated from measurements of aquifer specific yield. Specific yield is defined as the volume of water released from a unit area of an unconfined aquifer per unit decline in hydraulic head. Specific yield and effective porosity are equivalent if drainage of the aquifer matrix is complete. However, in reality, the specific yield may be lower than the effective porosity because of water held in pore spaces of the drained aquifer matrix by surface tension or adsorptive forces (Moench 1994).

As discussed in Section 2.5.2, specific yield can be calculated from 1) multiple well aquifer tests, or 2) measurements of the volume of aquifer drained or saturated in response to removing or injecting a known volume of ground water. A variation on the second method is presented in Appendix B. The specific yield was calculated from the change in saturated aquifer volume associated with dissipation of the ground-water mound beneath the 200-West Area from 1985 to 1995. The result was a specific yield value of 0.17 , which is higher than values calculated by Newcomb and Strand (1953) when they analyzed the growth of ground-water mounds beneath liquid disposal facilities in both the 200-West Area and 200-East Area between 1948 and 1953. Water levels beneath the 200-West Area had increased by an additional 5 to $10 \mathrm{~m}$ from 1953 to 1985. Therefore, the difference in porosity could be caused by a difference in the sediments saturated during the 1953 to 1985 period compared to those during 1985 to 1995 . Specific yield results from the relatively few multiple well tests conducted on the Hanford Site unconfined aquifer are listed in Section 2.5.2. These results range from 0.01 to 0.37 and average 0.15. However, some of these estimates are highly uncertain because the effects of nonideal test conditions, such as partially penetrating wells and aquifer heterogeneity. Such conditions generally have a more 
significant effect on the determination of storage properties than on the determination of transmissivity. Moench (1994) demonstrated that these conditions can affect specific yield values calculated from type-curve analysis of aquifer pumping tests, and usually result in the calculated values being low.

Mud-dominated units generally have higher porosity than sand-and-gravel-dominated units. Davis (1969) compiled porosity values that indicate ranges of 0.35 to 0.5 for silts and 0.4 to 0.7 for clays, respectively. However, because of the low permeability of such sediments, the porosity assigned to mud units in the model is not expected to have a major impact on model results.

\subsubsection{Dispersivity}

As a solute plume moves through the aquifer it is dispersed by a combination of mechanical mixing and molecular diffusion. The three-dimensional transport of an ideal conservative solute affected only by advection and dispersion as it travels through an ideal isotropic, homogeneous and rigid porous media is given by the mass balance equation

$$
\frac{\partial c}{\partial t}+v_{i} \frac{\partial c}{\partial x_{i}}=\frac{\partial}{\partial x_{i}}\left(D_{i j} \frac{\partial c}{\partial x_{j}}\right) \quad i, j=1,2,3
$$

where $\mathrm{c}$ is the solute concentration, $\mathrm{v}_{\mathrm{i}}$ is the seepage velocity in the $\mathrm{x}_{\mathrm{i}}$ direction, and $\mathrm{D}$ is the dispersion coefficient tensor. If $\mathrm{x}_{1}$ is taken as the mean direction of flow, then $\mathrm{v}_{1}=\mathrm{v}$ and $v_{2}=v_{3}=0$. The dispersivity, $\alpha_{i}$, is defined for each of the principal directions as $\alpha_{i}=D_{i} / v$. However, it has been demonstrated that the field scale dispersivity, or macrodispersivity, is generally much larger than the small scale dispersivity measured in the laboratory. Therefore, macrodispersivity is generally denoted as $\mathrm{A}_{\mathrm{L}}, \mathrm{A}_{\mathrm{T}}$, and $\mathrm{A}_{\mathrm{V}}$ in the longitudinal, horizontal transverse, and vertical transverse directions, respectively.

The scale dependence of dispersivity is generally believed to result from spatial and temporal variations in the ground-water velocity field, which are caused by both spatial variations in hydraulic conductivity, and spatial and temporal variations in hydraulic gradient (Goode and Konikow 1990). Aquifer heterogeneity results in additional plume dispersion, beyond that seen in the laboratory, because the solute moves at different rates through different parts of the aquifer. Temporal variations in hydraulic gradient have been shown to have a strong effect on transverse dispersion (Goode and Konikow 1990; Rehfeldt and Gelhar 1992; van der Kamp et al. 1994). 
Theoretically, the differences in flow paths that cause macrodispersion could be accounted for in a numerical flow model by a detailed delineation of the hydraulic conductivity throughout the model domain. However, this approach is impractical for large-scale problems because 1) such detailed and accurate information on hydraulic conductivity is not usually available, and 2) the number of elements required would be too large for most computers to handle. For example, Rehfeldt and Gelhar (1992) calculated that a minimum of 2 billion elements would be required to describe the hydraulic conductivity distribution for the Cape Cod sewage plume, which is $3500 \mathrm{~m}$ long, $1000 \mathrm{~m}$ wide, and $25 \mathrm{~m}$ thick. Because of these problems, the generally accepted approach for modeling dispersion is to use field scale macrodispersivity values.

Longitudinal dispersivity applied in a two-dimensional transport model accounts for dispersion caused by vertical variations in ground-water flow paths. In a three-dimensional model, some of these different flow paths are built into the model. Therefore, the correct longitudinal dispersivity for a three-dimensional model may be smaller than for the corresponding twodimensional model.

Possible approaches for determining the appropriate dispersivity values for the Hanford sitewide three-dimensional model include

- direct measurement through field tracer tests

- analysis of historical plume behavior through either analytical methods or modeling

- adoption of values cited in the literature for similar sites.

The third approach has generally been used in the past for determining dispersivity values for Hanford Site transport modeling. Law (1992) used values of $A_{L}=43 \mathrm{~m}$ and $A_{T}=12 \mathrm{~m}$ for a scale of $9500 \mathrm{~m}$ based on values compiled in Gelhar et al. (1985). An earlier model (WHC 1990) used values of $15 \mathrm{~m}$ and $1.5 \mathrm{~m}$, respectively, for longitudinal and transverse dispersivity, which were also based on Gelhar et al. (1985).

Dispersivity values determined from field tests at 59 different sites were compiled by Gelhar et al. (1992). These include results from two investigations at the Hanford Site. The first was a 1950 s tracer test that resulted in values of $A_{L}=6 \mathrm{~m}$ and $A_{L}=460 \mathrm{~m}$ for the Hanford and Ringold formations, respectively, as reported by Bierschenk (1959). Also included are values of 
$A_{L}=30.5 \mathrm{~m}$ and $A_{T}=18.3 \mathrm{~m}$ for a scale of $20,000 \mathrm{~m}$. These were calculated from twodimensional transport modeling of the 200-East tritium plume as reported in Ahlstrom et al. (1977). The dispersivity data in Gelhar et al. (1985) were classified according to quality of data and plotted to show the correlation between scale of observation and dispersivity values. Separate plots are presented for longitudinal, horizontal transverse, and vertical transverse dispersivity. Longitudinal and horizontal transverse dispersivity show a positive correlation with scale of observation. A correlation was not indicated for vertical transverse dispersivity. However, very few measured vertical dispersivity values were available.

Dispersivity is likely to vary across the Hanford Site depending on the degree of heterogeneity and the temporal variability of flow gradients. Ahlstrom et al. (1977) noted that the ratio of $A_{T}$ to $A_{L}$ calculated from their model of the Hanford Site was much higher than the ratio expected. They attributed the high ratio to heterogeneity. However, horizontal dispersion may have been enhanced by temporal variations in flow gradients caused by disposal practices. The flow paths for the tritium transport from the 200-East Area have gradually shifted from due east to a south-easterly direction, in response to waste-water discharges to B Pond and the 200-East Area. This shift in the flow path has enhanced the apparent dispersion of the tritium plume emanating from the 200-East Area.

\subsection{Contaminant Distributions}

To establish initial conditions for a transport model, information on both the areal and vertical distributions of contaminants within the unconfined aquifer is needed. Temporal data on the distribution of contaminants is also needed for model calibration.

Concentrations of both chemical and radiological contaminants are measured in hundreds of Hanford Site wells each year. Contaminant distributions measured during 1994 and information on sampling and analysis techniques are provided in Dresel et al. (1995). Like the hydraulic-head measurement network, the current sampling network is composed mainly of wells completed in the upper part of the unconfined aquifer system, generally less than $7 \mathrm{~m}$ below the water table. Most of the wells that were originally open to a greater depth interval were reconfigured in the early 1980 s based on an investigation by Eddy et al. (1978), which showed that contaminant concentrations were highest near the top of the aquifer. The sampling network wells were, therefore, reconfigured so 
that ground water containing the highest concentrations was sampled and dilution with relatively uncontaminated water from deeper in the aquifer was avoided. Remediation of the sampling wells also eliminated the potential for enhanced vertical migration of contaminants through the well casing.

A limited number of wells and piezometers completed in the deeper part of the unconfined aquifer system are currently available. However, for some of the piezometer completions, the integrity of the seals between intervals is questionable. As mentioned in the last section, some wells containing several piezometers in a single perforated well casing were originally completed by backfilling around the piezometer tubes with sand. Because the sand may not have provided adequate isolation of the individual depth intervals, data obtained from these piezometers are suspect and should not be used. Most of the piezometers containing sand backfill were recompleted in the 1970 s and 1980s by removing the sand and placing cement seals to isolate piezometer intervals. However, as noted in Appendix D, some piezometer wells still have apparent completion problems. Table 2.4 lists contaminant data for some deeper sample intervals within the unconfined aquifer system. All of the vertical contaminant data listed in Table 2.4 are from individual wells or piezometers with documented cement seals isolating the depth intervals and where head differences exist between different isolated intervals. The data indicate that small amounts of contaminants are found at depths of at least $50 \mathrm{~m}$ below the water table in some areas of the Hanford Site and their concentrations decrease with depth. 
Table 2.4. Vertical Contaminant Data

\begin{tabular}{||c|c|c|c|c|c||}
\hline Well & $\begin{array}{c}\text { Date } \\
\text { Sampled }\end{array}$ & $\begin{array}{c}\text { Water } \\
\text { Table } \\
\text { Depth }(\mathrm{m})\end{array}$ & $\begin{array}{c}\text { Sampled Interval } \\
\text { Depth (m) }\end{array}$ & $\begin{array}{c}\text { Tritium } \\
(\mathrm{pCi} / \mathrm{L})\end{array}$ & $\begin{array}{c}\text { Nitrate } \\
(\mathrm{mg} / \mathrm{L})\end{array}$ \\
\hline 299-W22-24 T & $7 / 11 / 95$ & 73.1 & $89.0-96.6$ & 16,900 & $<0.02$ \\
\hline 299-W22-24 R & $7 / 11 / 95$ & 73.1 & $125.6-133.2$ & 296 & 0.2 \\
\hline 299-W22-24 Q & $7 / 11 / 95$ & 73.1 & $144.8-151.5$ & 194 & 0.5 \\
\hline $699-14-\mathrm{E} 6 \mathrm{~S}$ & $6 / 14 / 95$ & 28.3 & $88.4-92.1$ & $<10$ & NA \\
\hline $699-18-21$ & $6 / 12 / 95$ & 43.1 & $58.5-70.7$ & 133,000 & NA \\
\hline $699-24-01 \mathrm{~S}$ & $6 / 13 / 95$ & 31.7 & $60.4-67.4$ & $<10$ & NA \\
\hline $699-24-01 \mathrm{R}$ & $6 / 13 / 95$ & 31.7 & $89.3-95.7$ & $<10$ & NA \\
\hline $699-24-01 \mathrm{Q}$ & $6 / 13 / 95$ & 31.7 & $96.6-108.2$ & $<10$ & NA \\
\hline $699-28-40 \mathrm{Q}$ & $6 / 14 / 95$ & 48.2 & $103.6-106.7$ & 815 & NA \\
\hline $699-31-11$ & $6 / 12 / 95$ & 28.7 & $56.7-73.8$ & 156,000 & NA \\
\hline $699-36-46 \mathrm{R}$ & $7 / 11 / 95$ & 91.7 & $109.7-116.4$ & $<10$ & $<0.02$ \\
\hline $699-36-46 \mathrm{Q}$ & $3 / 23 / 95$ & 90.8 & $131.1-137.8$ & $<200$ & 0.03 \\
\hline
\end{tabular}

$\mathrm{NA}=$ not analyzed. 


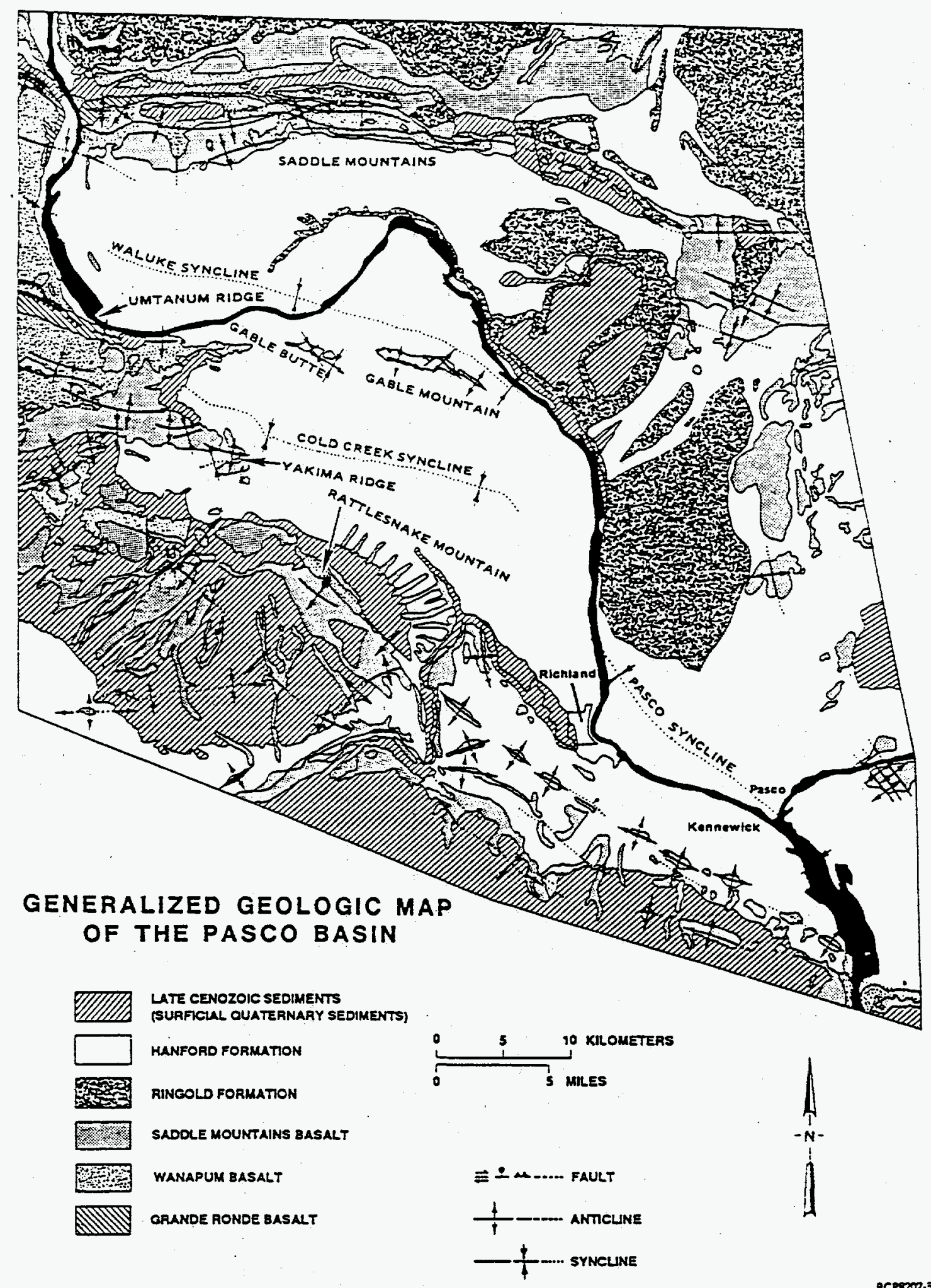

ACpereon-51

Figure 2.1. Surface Geology and Structural Features of the Pasco Basin (Reidel et al. 1992) 


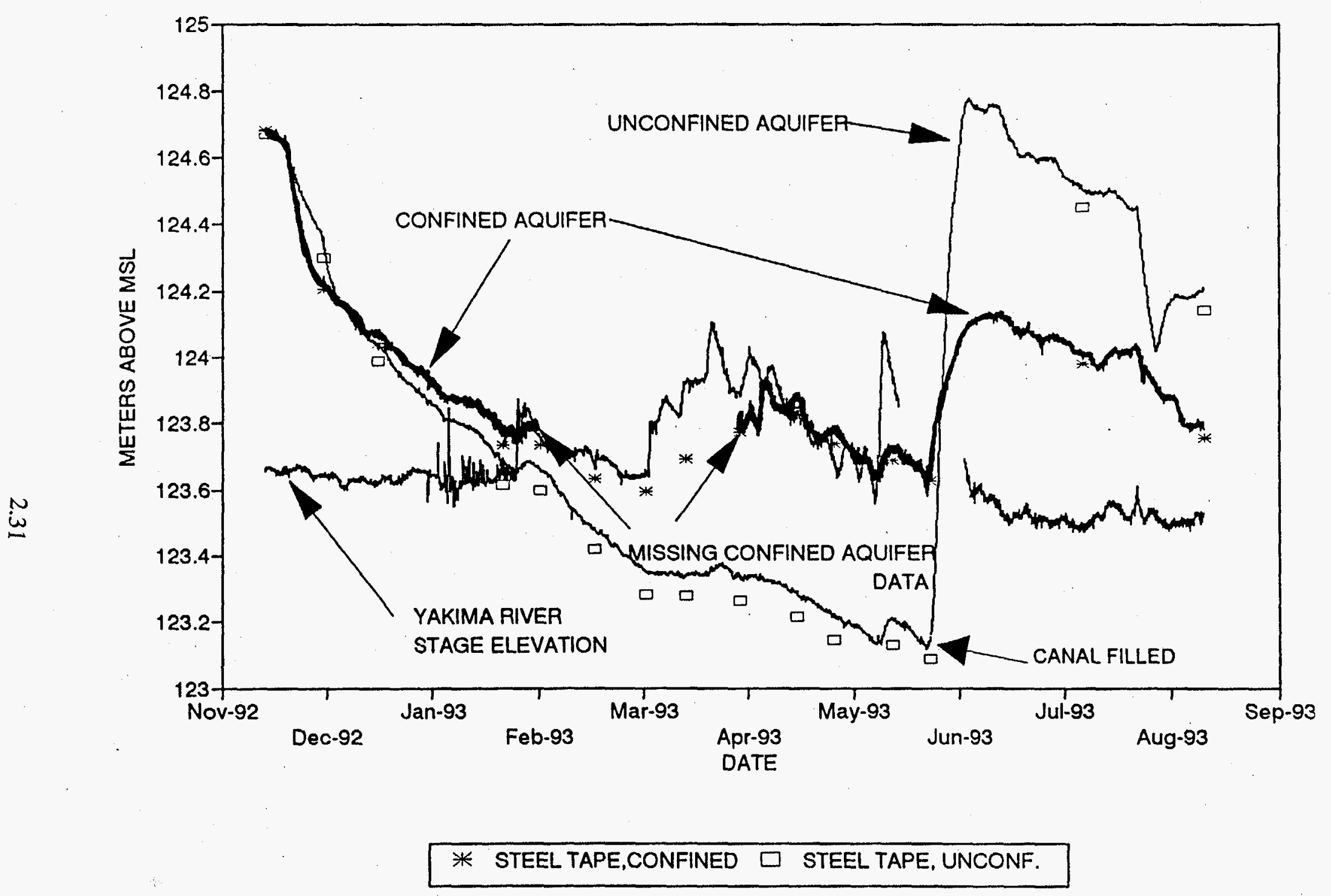

Figure 2.2. Yakima River Stage and Water Level Elevations in the Unconfined and Confined Aquifers at Well 699-S24-19 


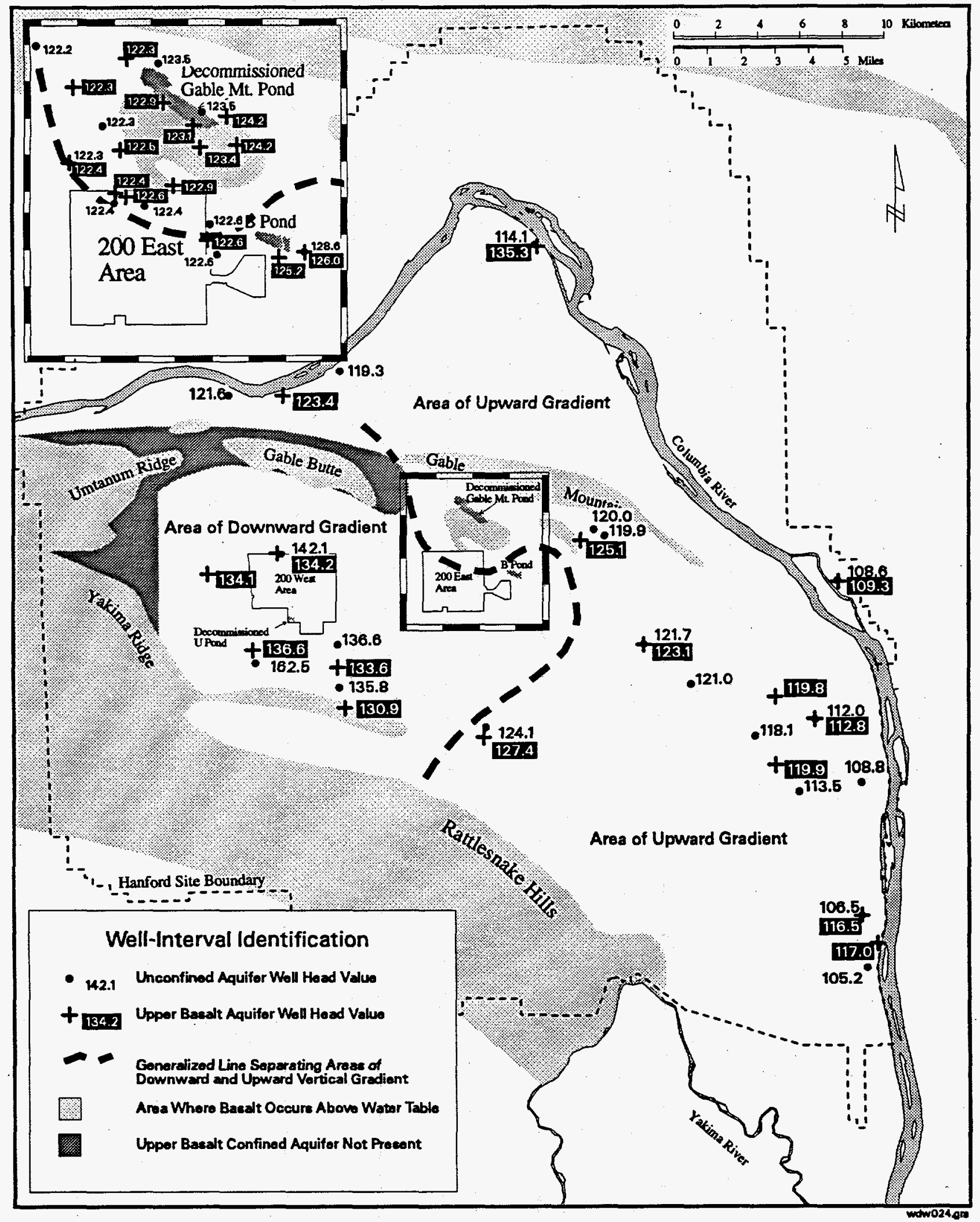

Figure 2.3. Comparison of Observed Heads for the Upper Basalt and Overlying Unconfined Aquifer Systems (Spane and Webber 1995) 


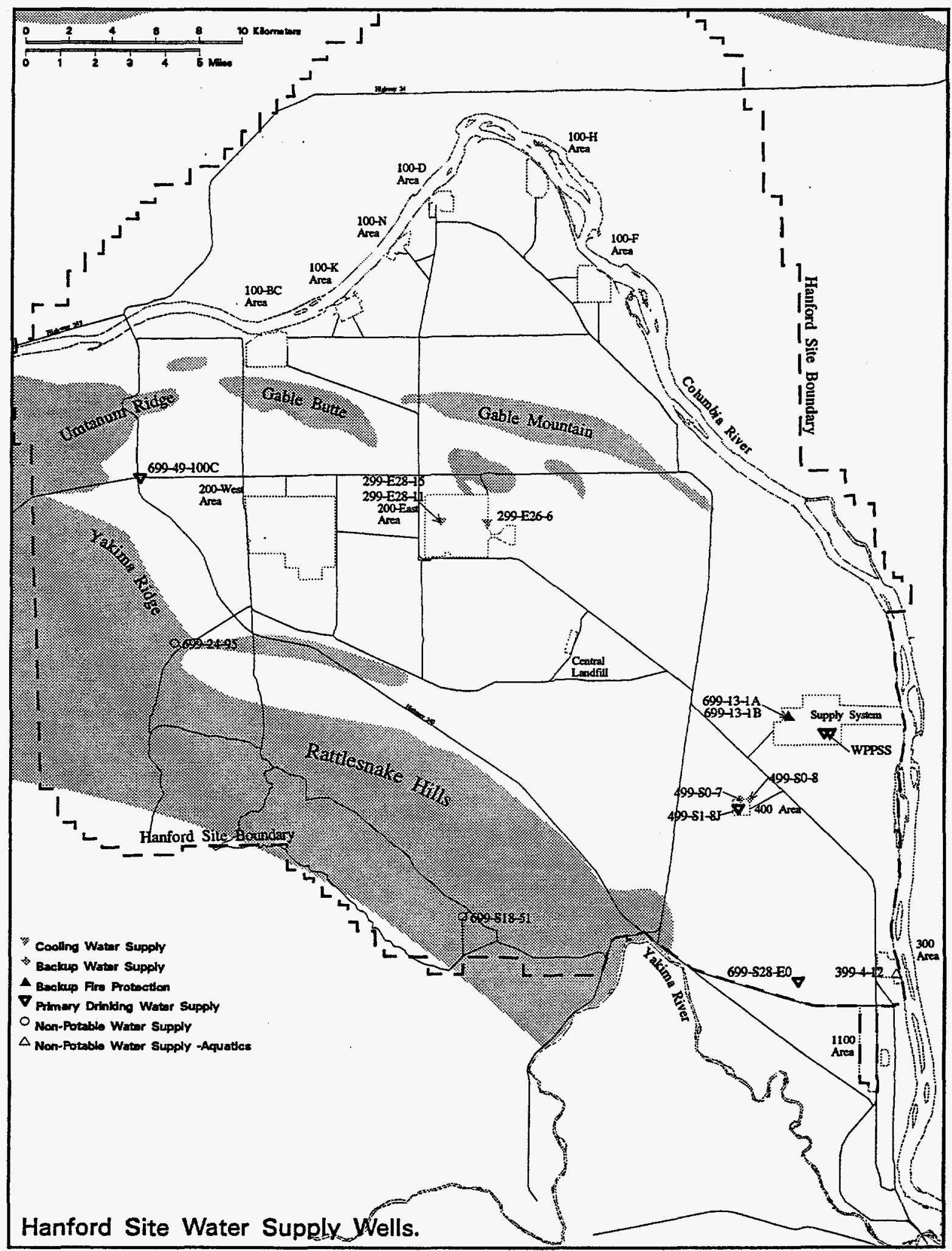

Figure 2.4. Hanford Site Water Supply Wells (Barnett et al. 1995) 


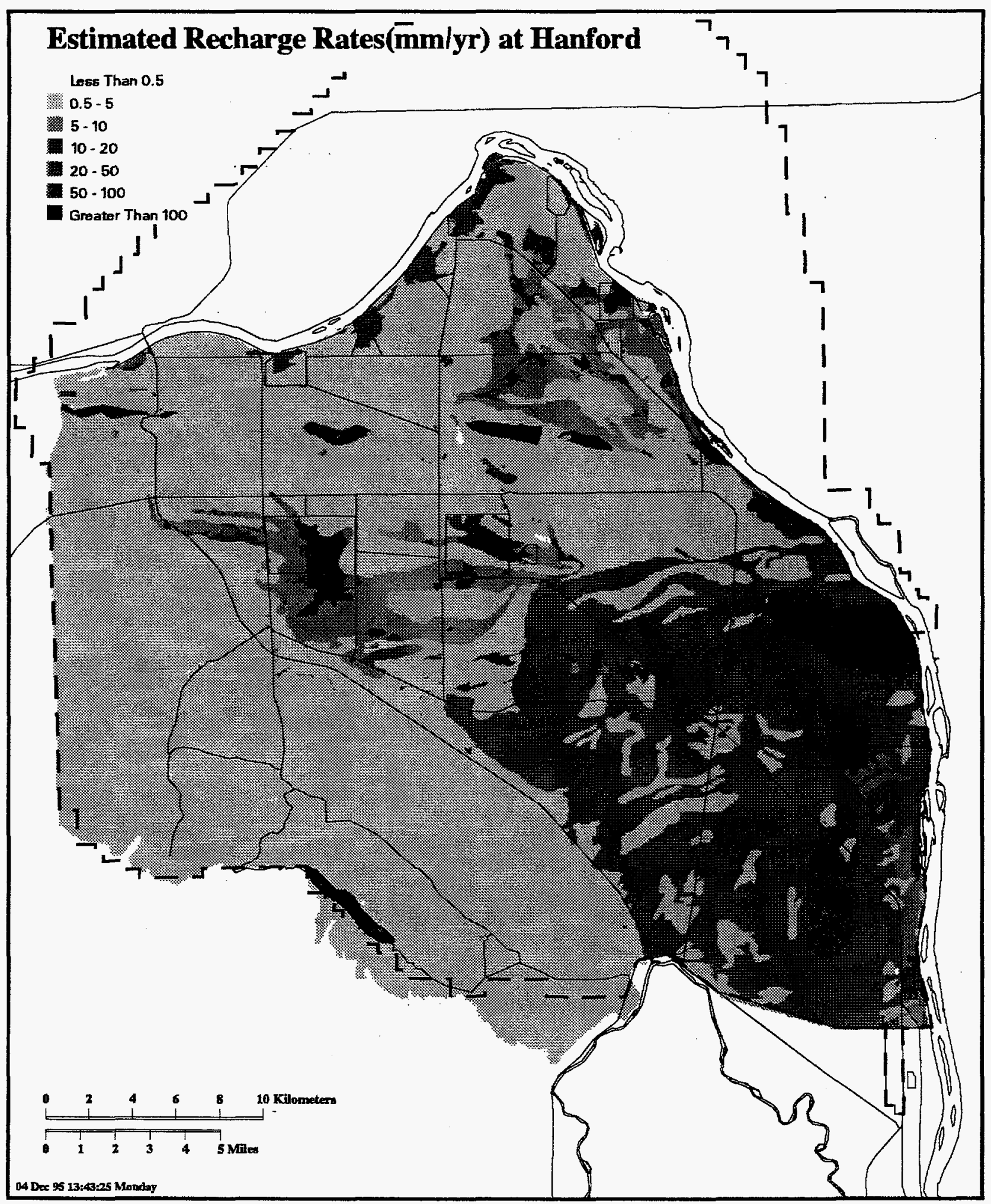

Figure 2.5. Natural Recharge Distribution for the Hanford Site 


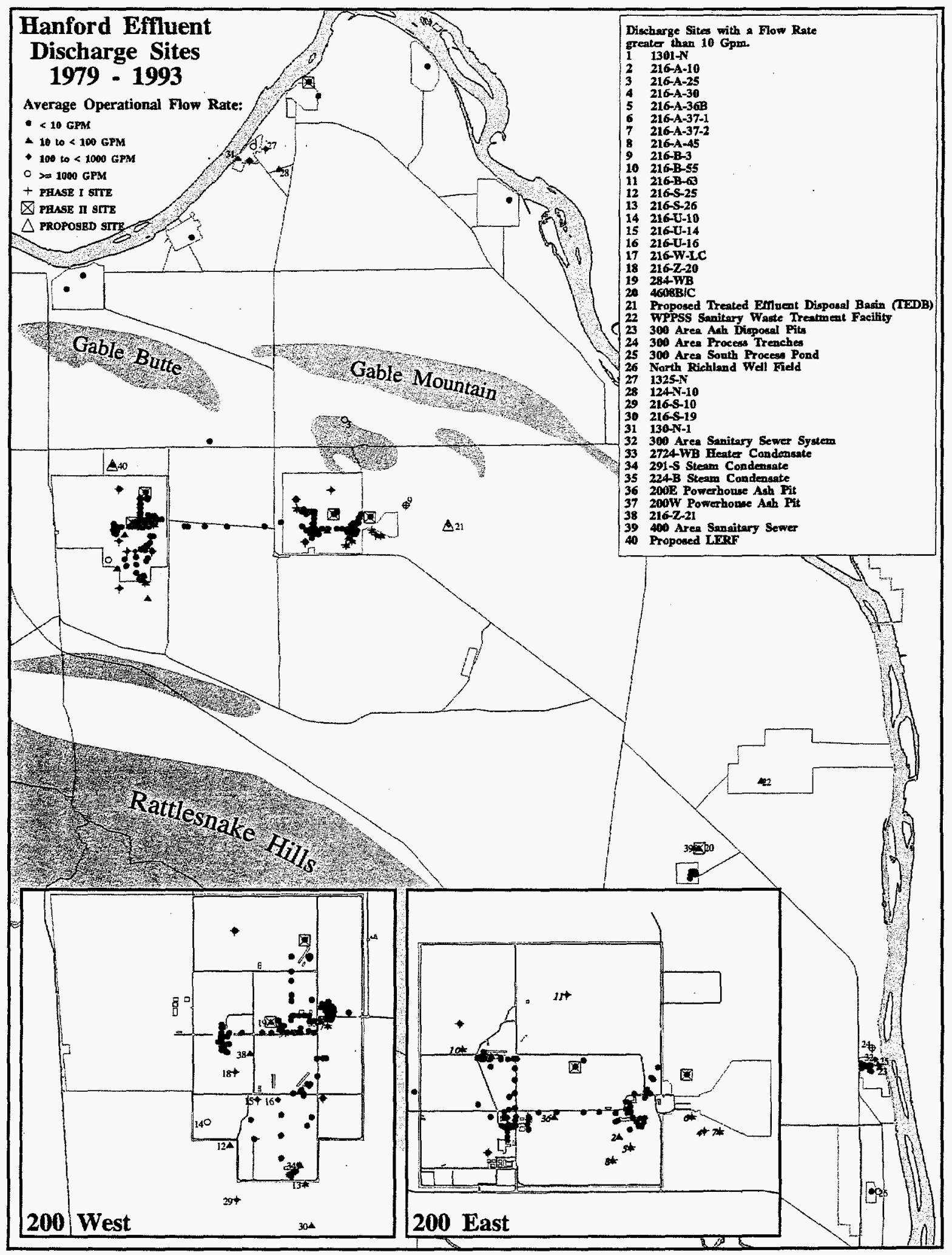

Figure 2.6. Hanford Effluent Discharge Sites (Barnett et al. 1995) 


\section{Hydrograph of Net Artificial Recharge to the Unconfined Aquifer}

at the Hanford Site and Richland (Annual Volumes)

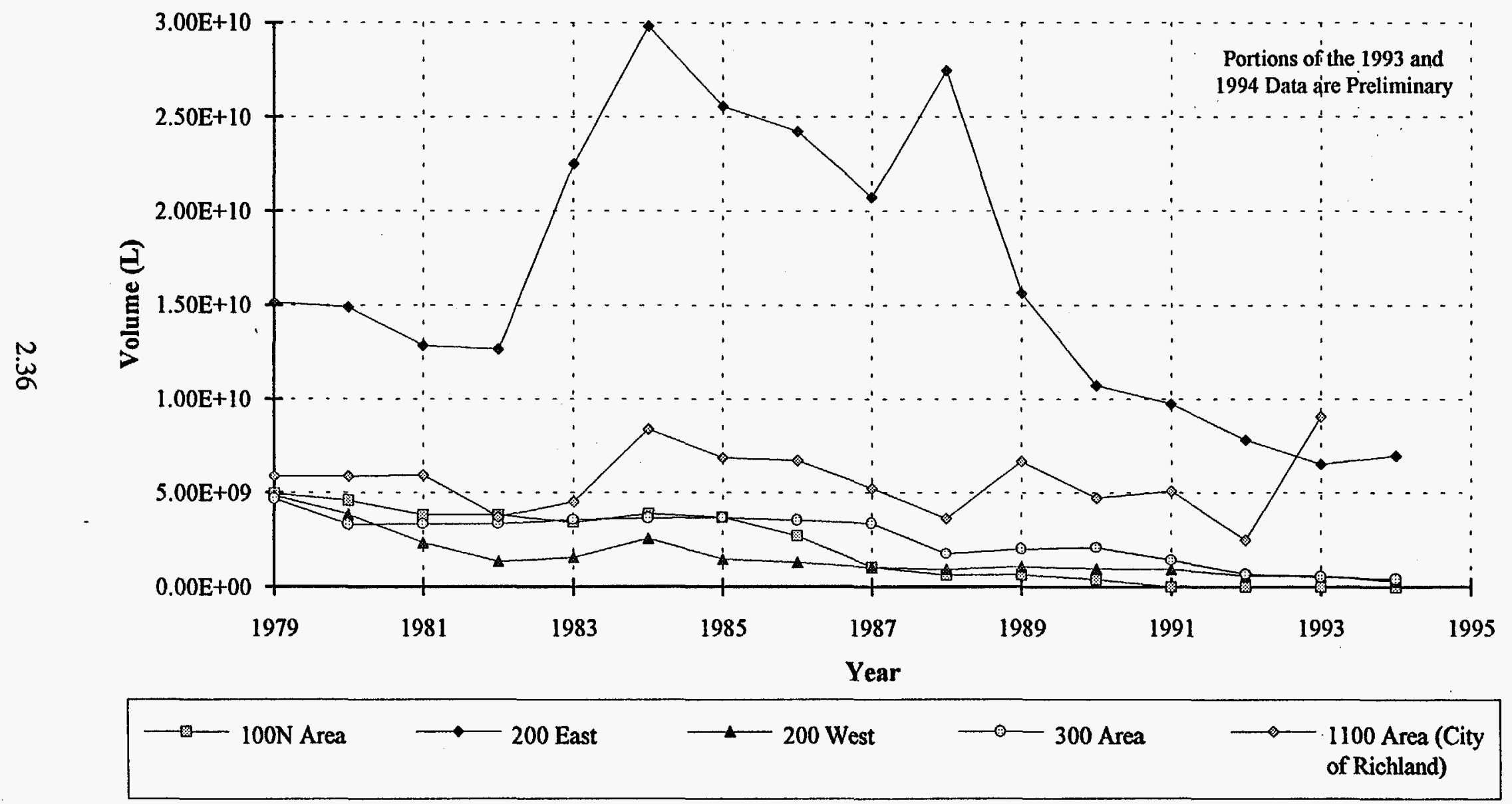

Figure 2.7. Hydrograph of Waste Streams at the Hanford Site 1979 to 1994 (Barnett et al. 1995) Printed: 7/12/95 12:2 

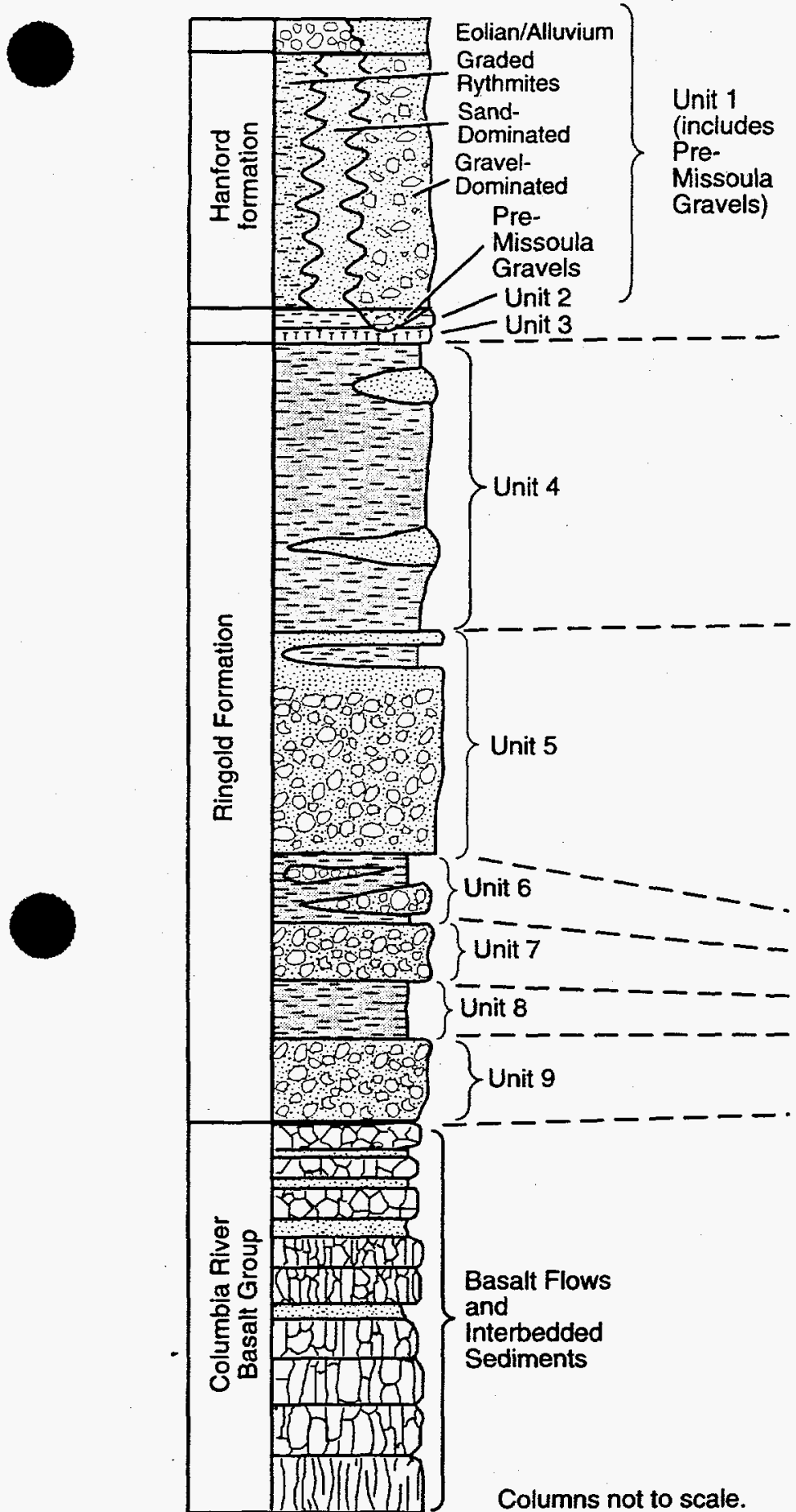

This report

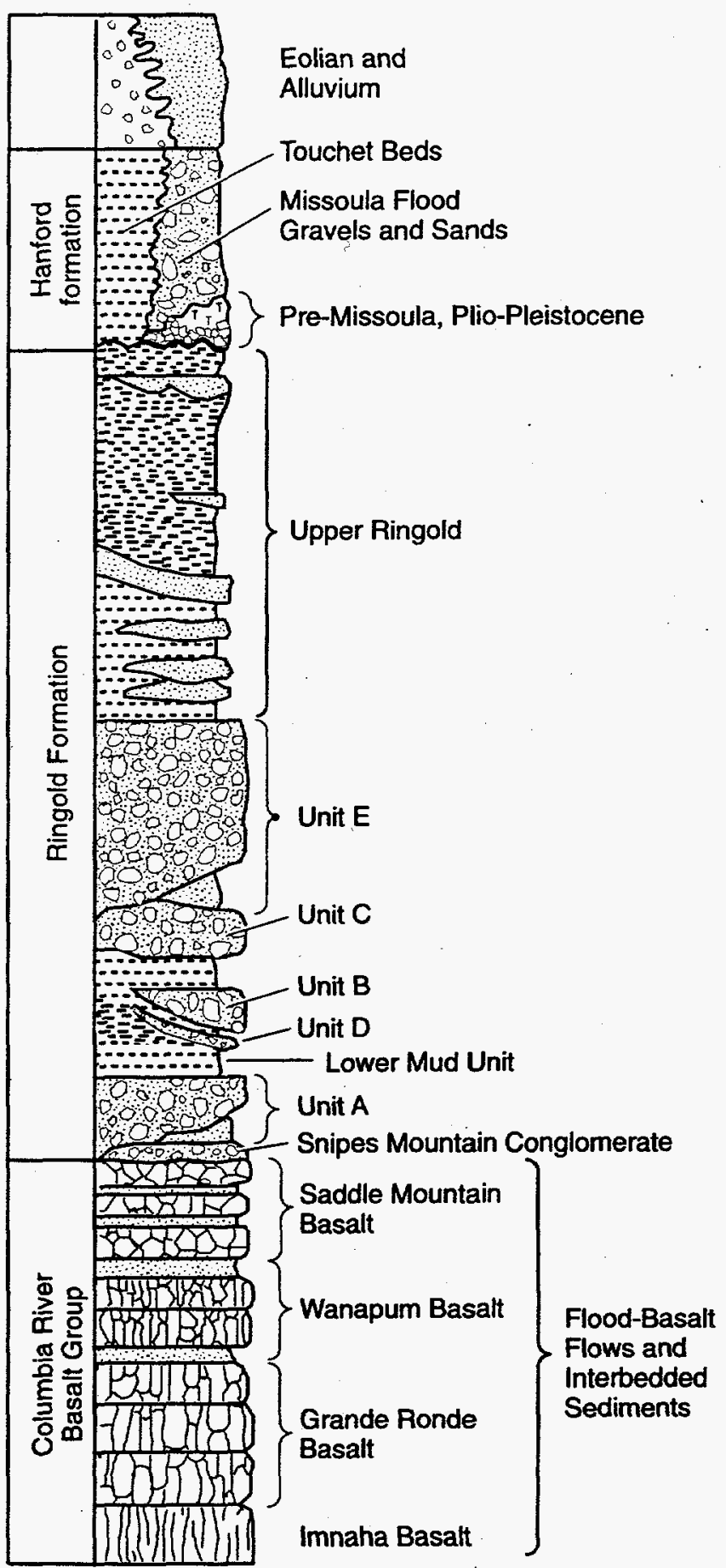

(Modified from Lindsey 1995)

SG95110411.2

Figure 2.8. Comparison of Generalized Geology and Hydrogeologic Stratigraphic Columns 


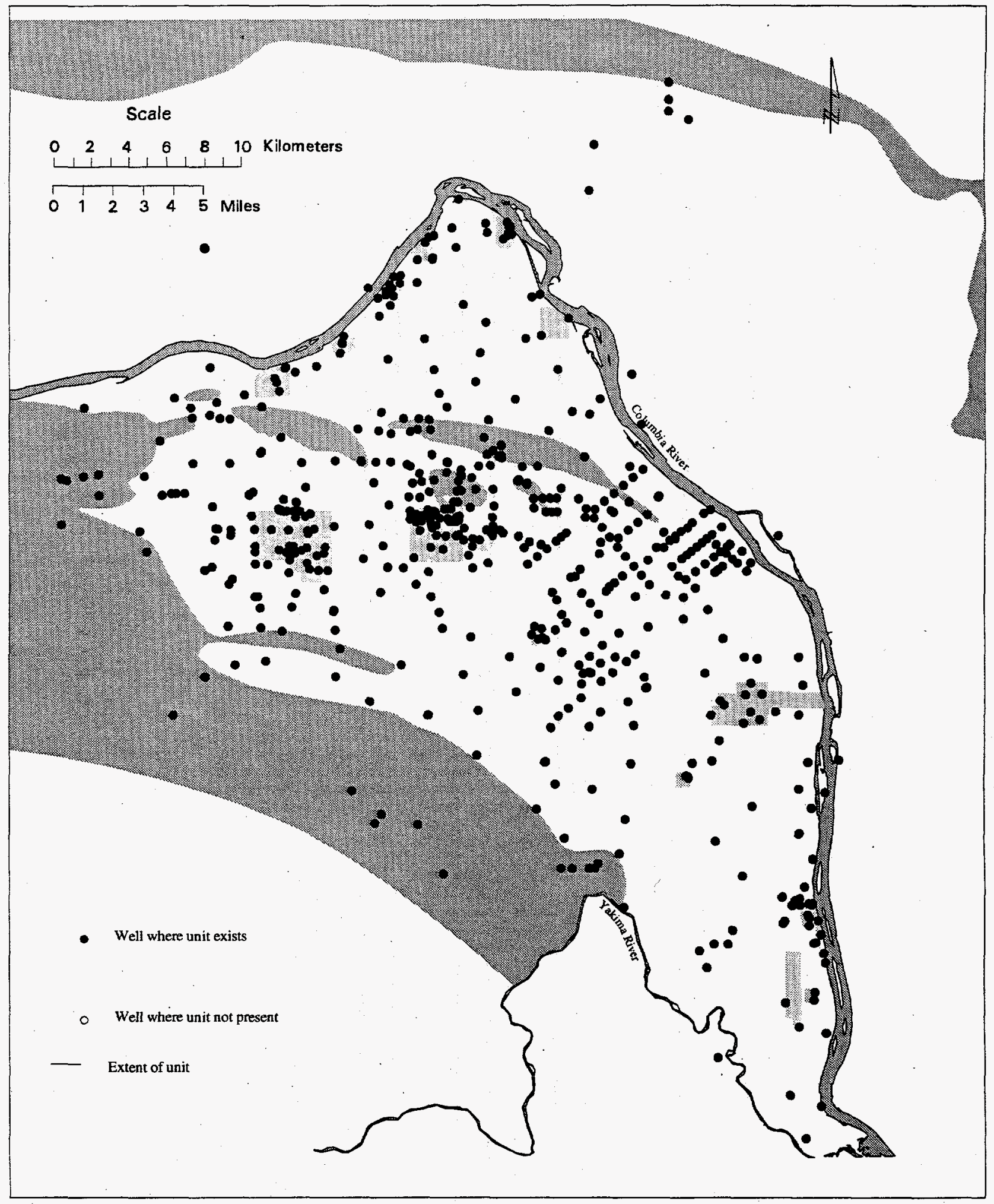

Figure 2.9. Distribution of Wells Used to Define Three-Dimensional Hydrogeologic Structure 


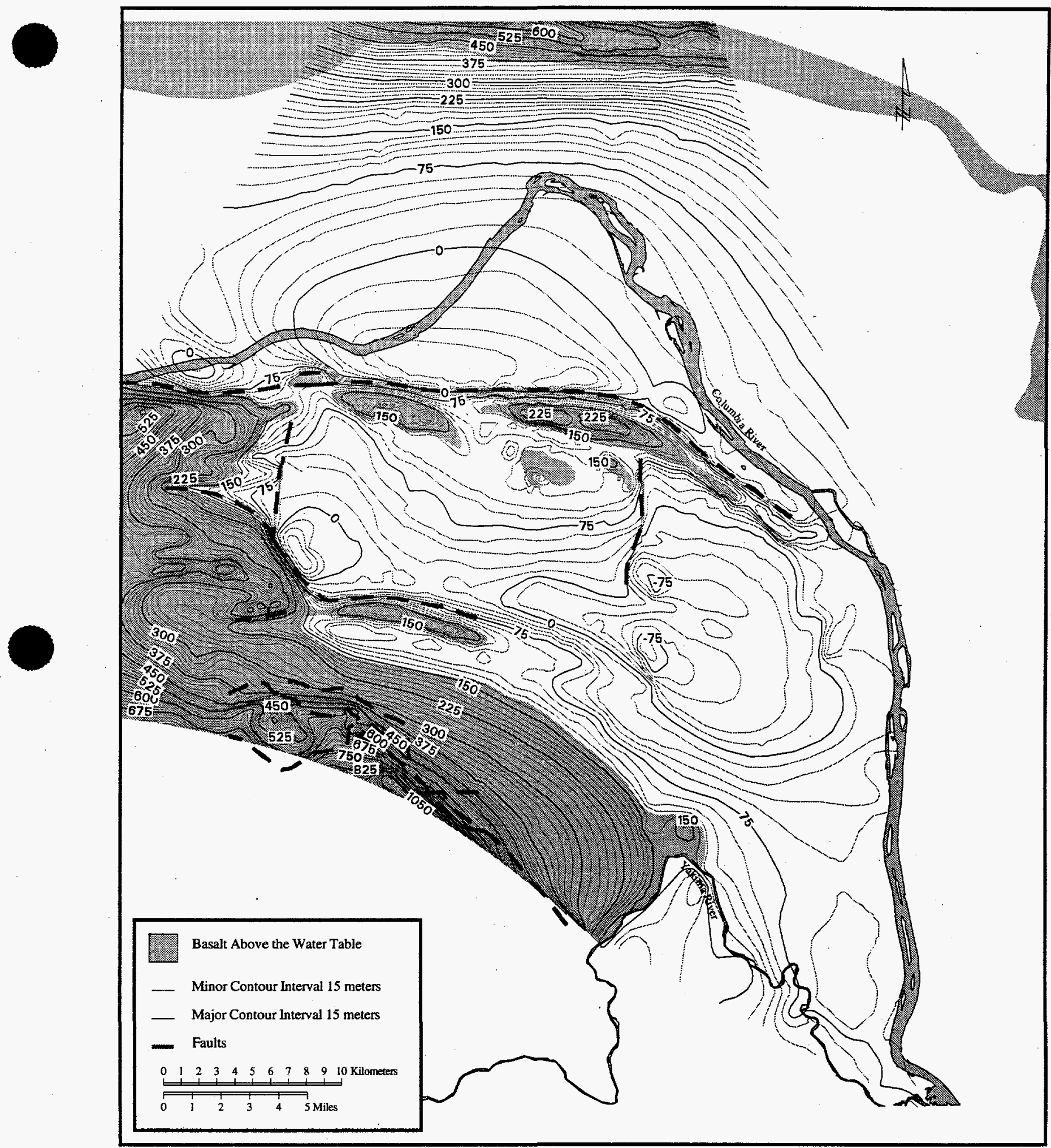

Figure 2.10. Structure Contour Map of the Top of Basalt, Based on Model Input, 1995 


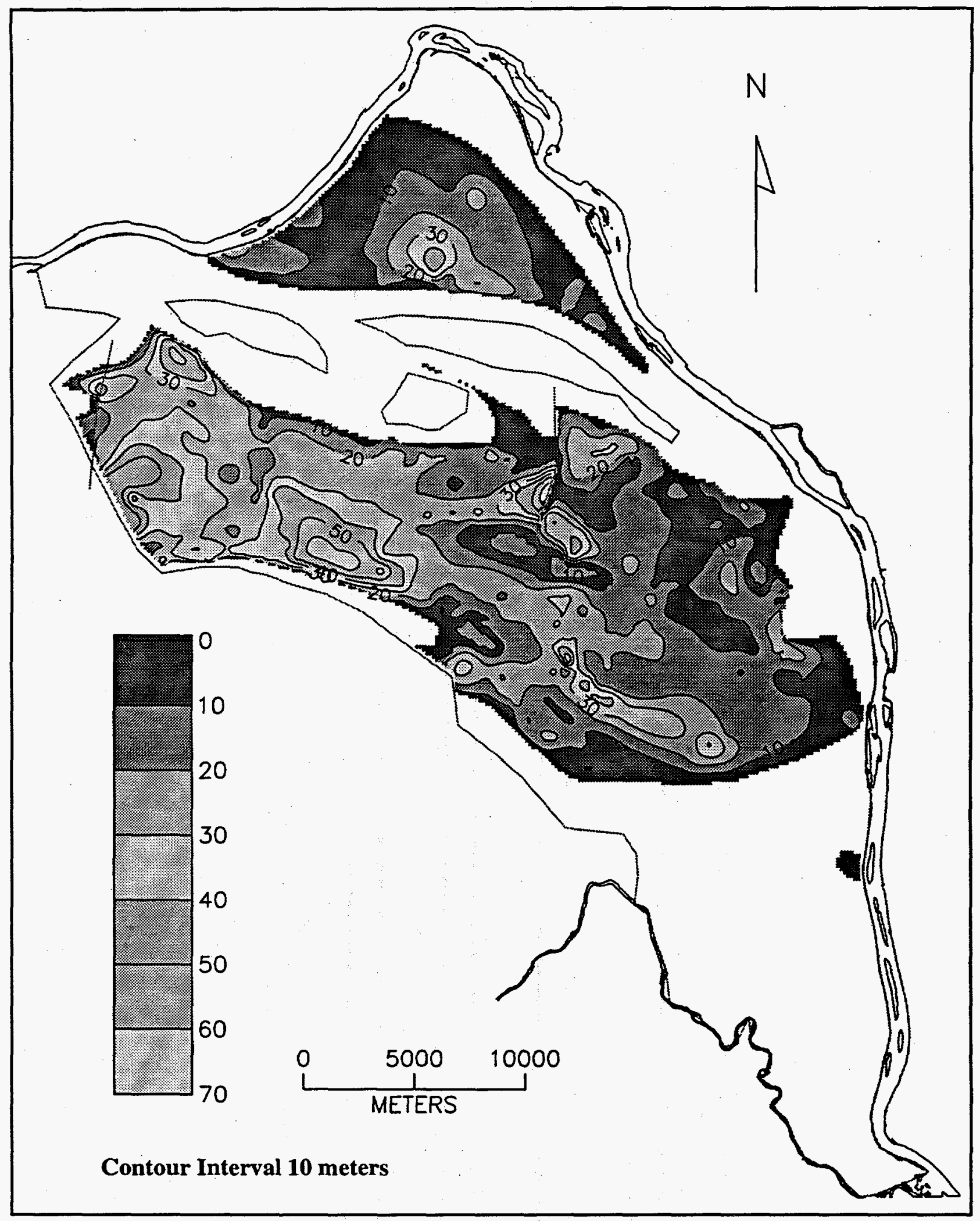

Figure 2.11. Isopach Map of Unit 9 


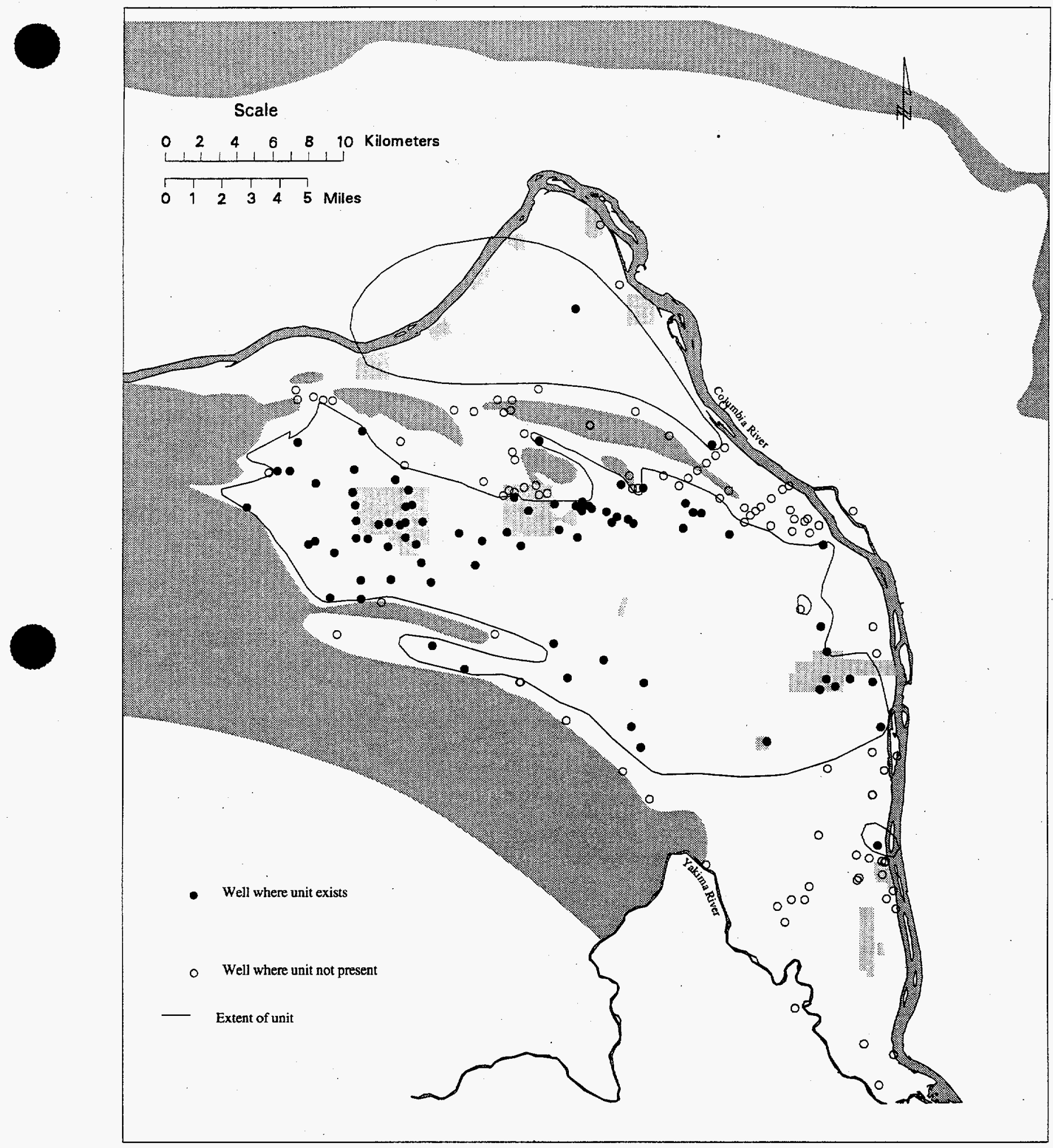

Figure 2.12. Distribution of Wells Where Unit 9 Was Identified 


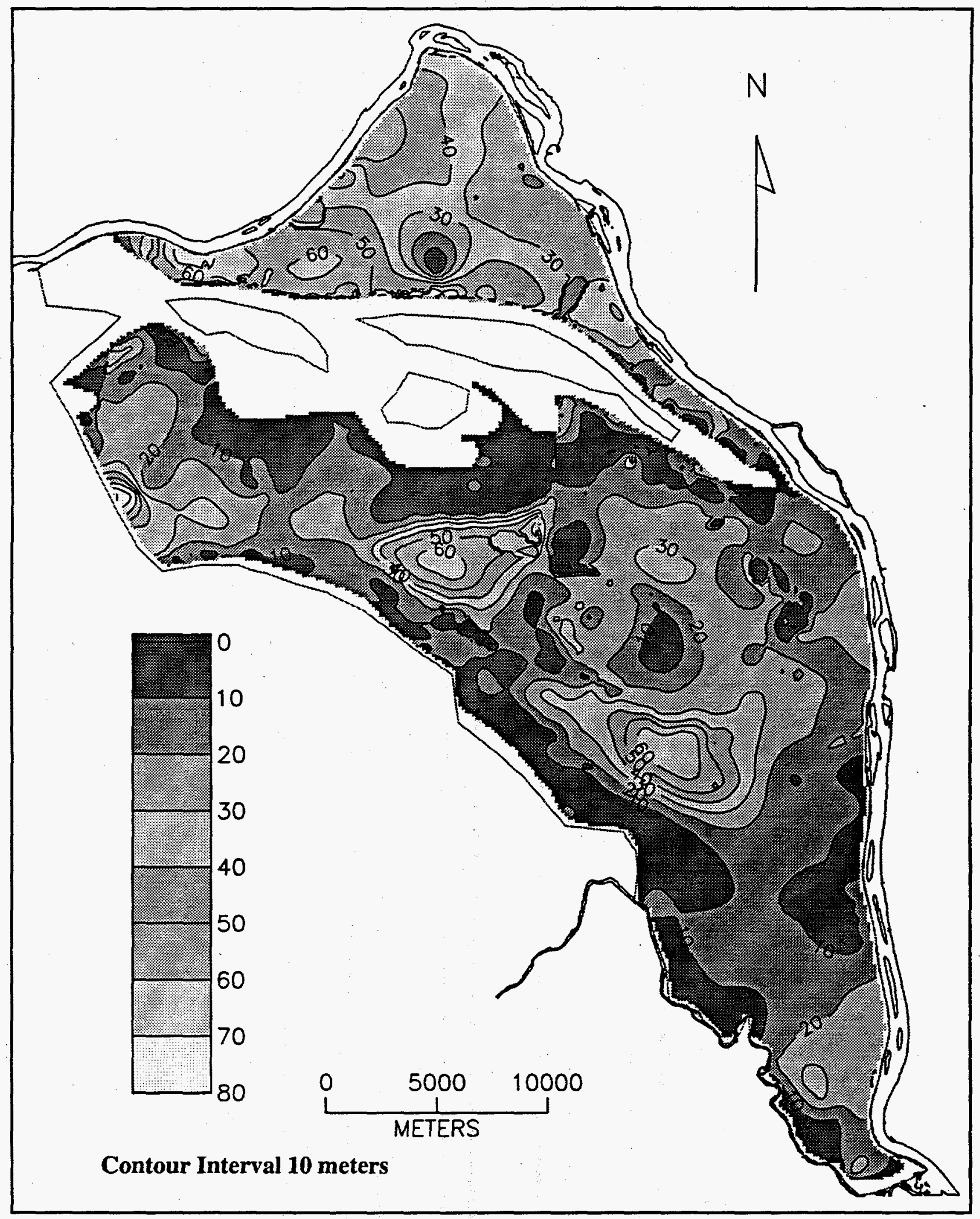

Figure 2.13. Isopach Map of Unit 8 


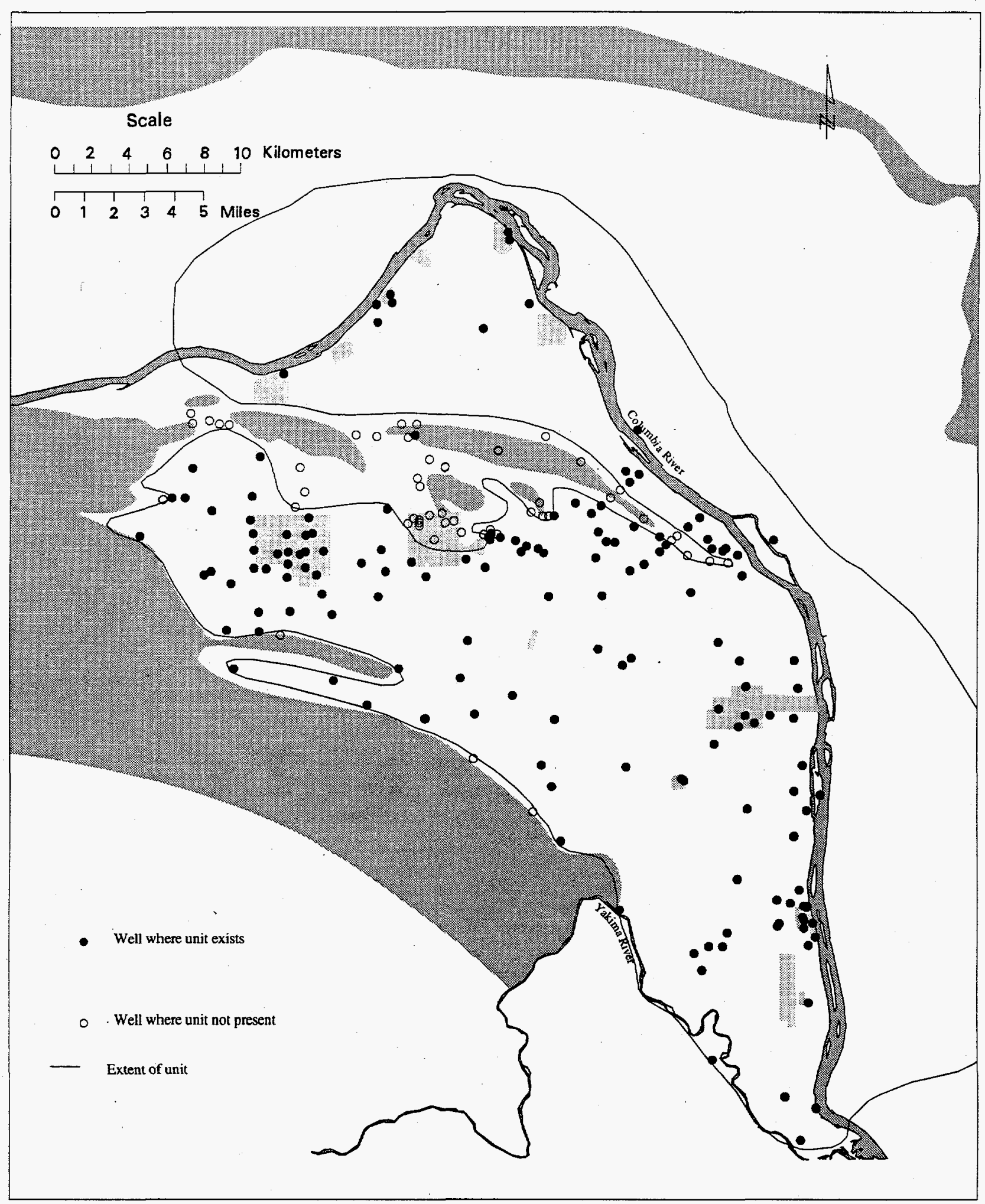

Figure 2.14. Distribution of Wells Where Unit 8 Was Identified 


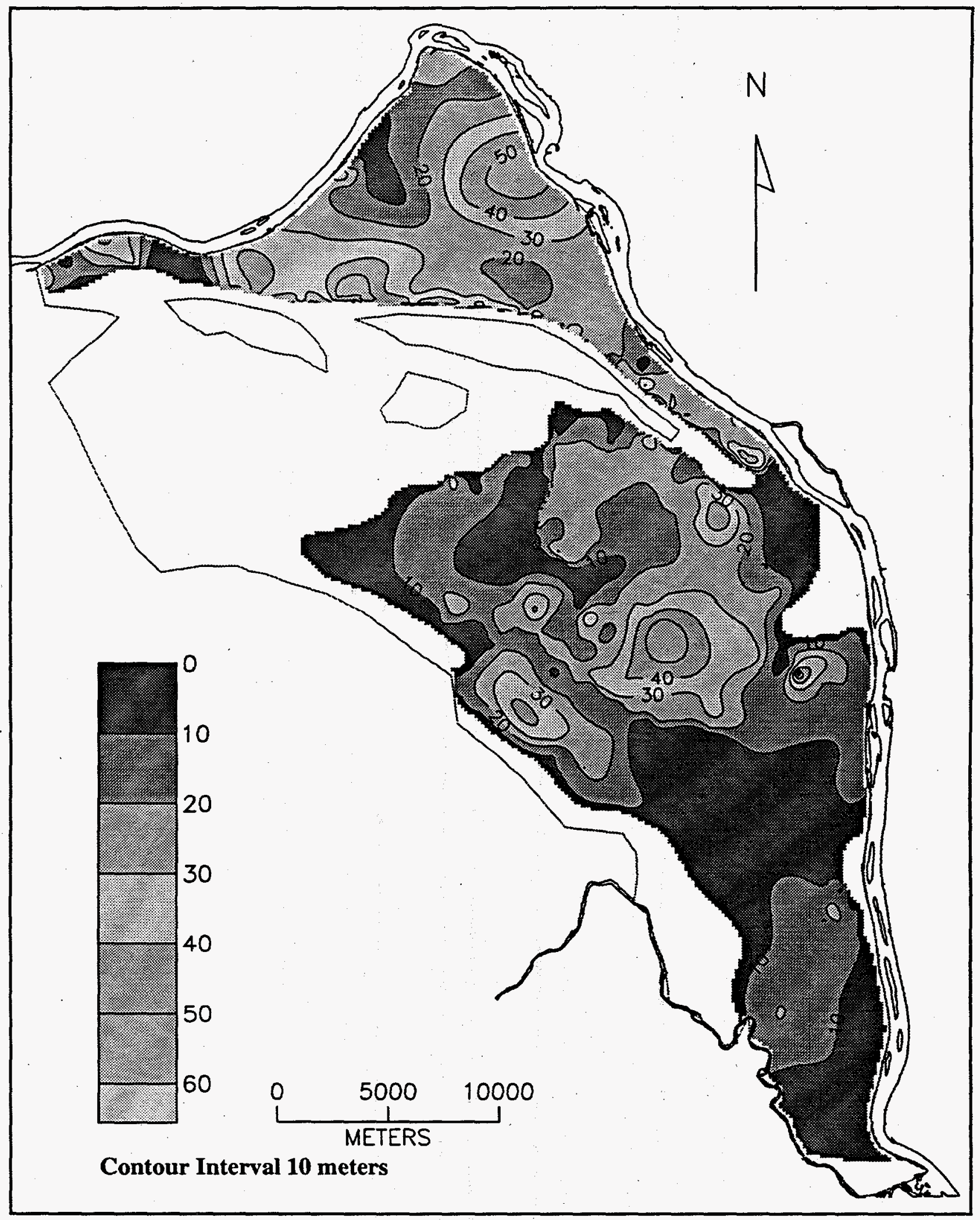

Figure 2.15. Isopach Map of Unit 7 


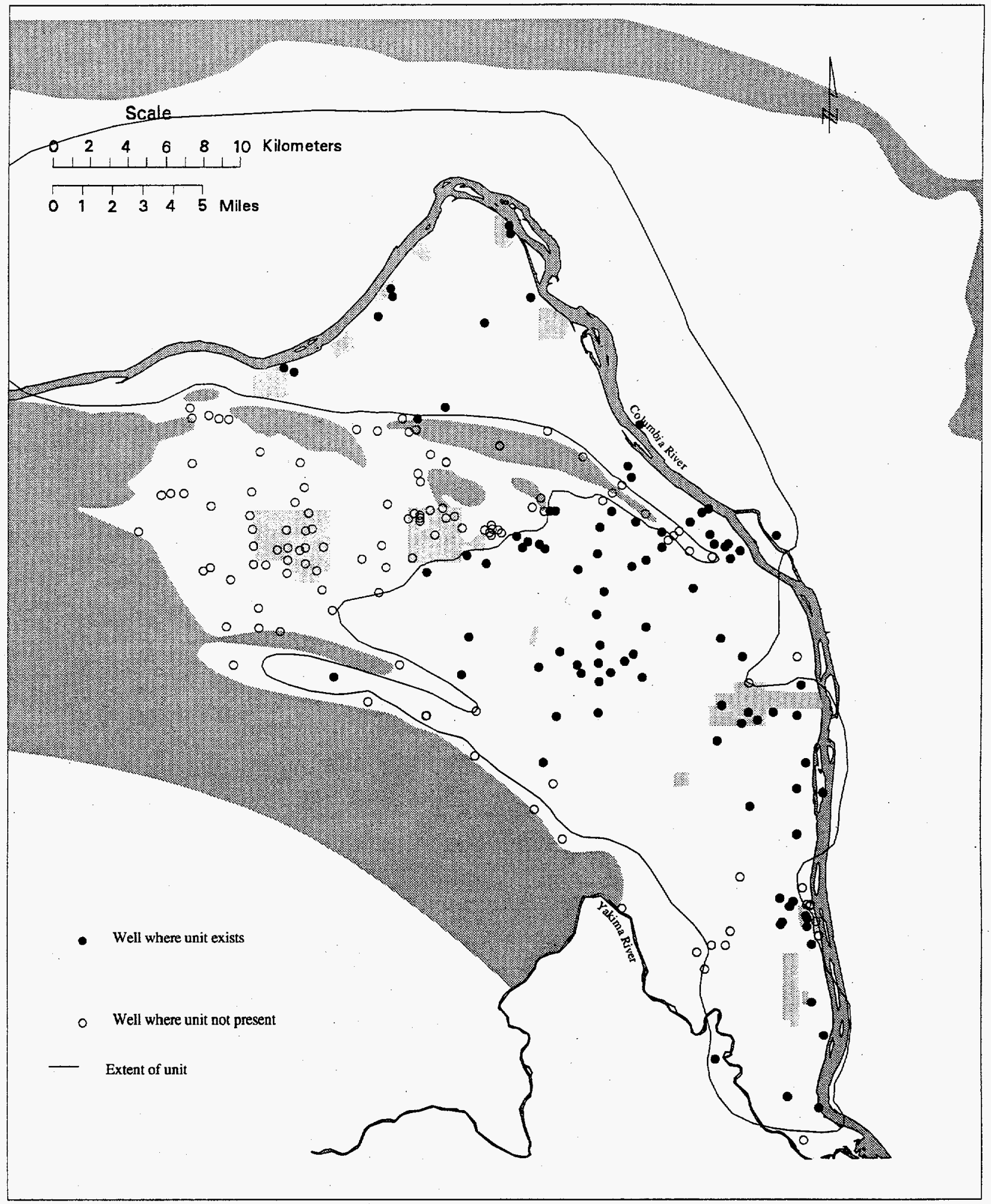

Figure 2.16. Distribution of Wells Where Unit 7 Was Identified 


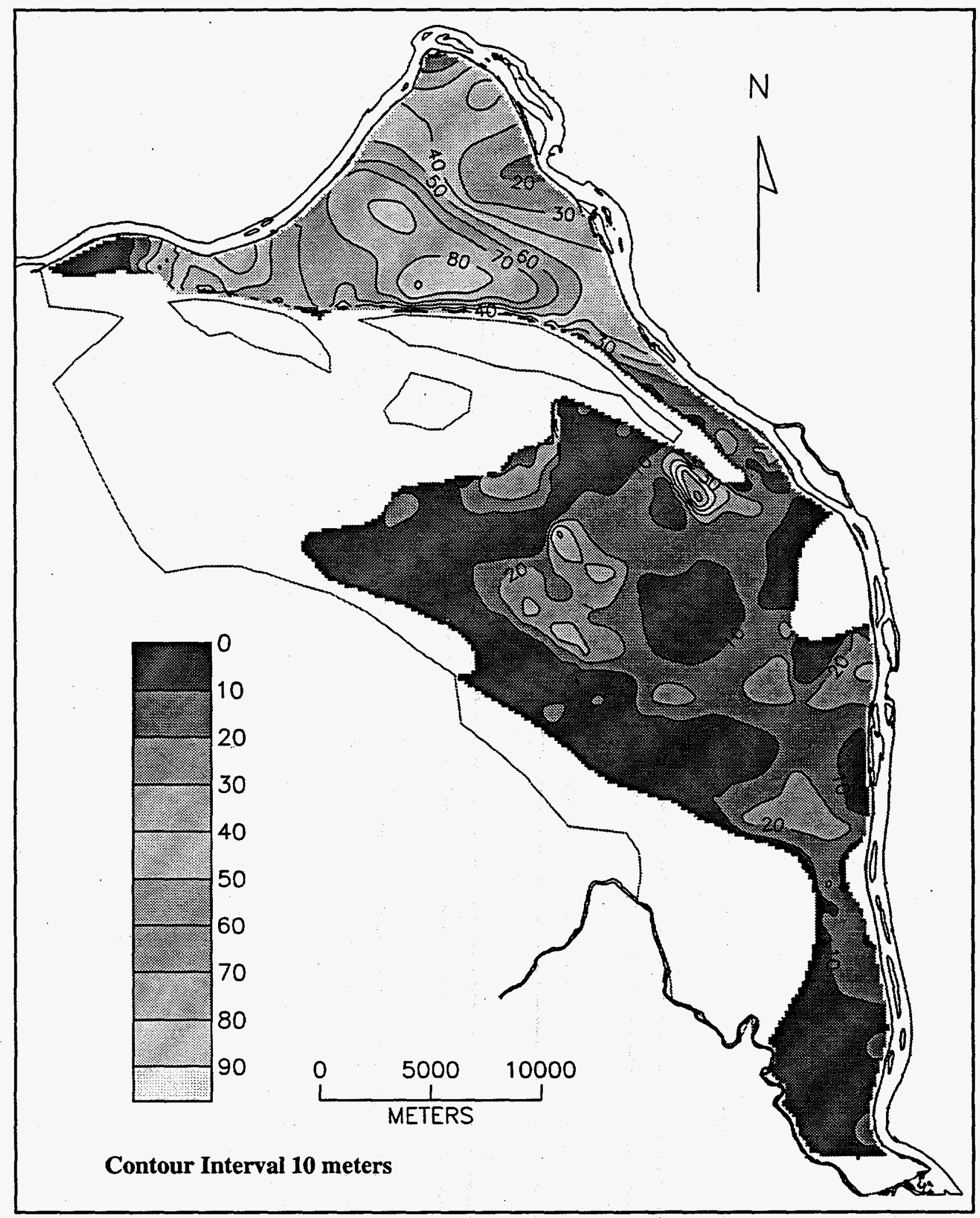

Figure 2.17. Isopach Map of Unit 6 


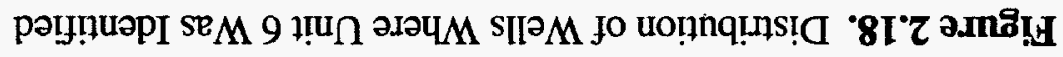

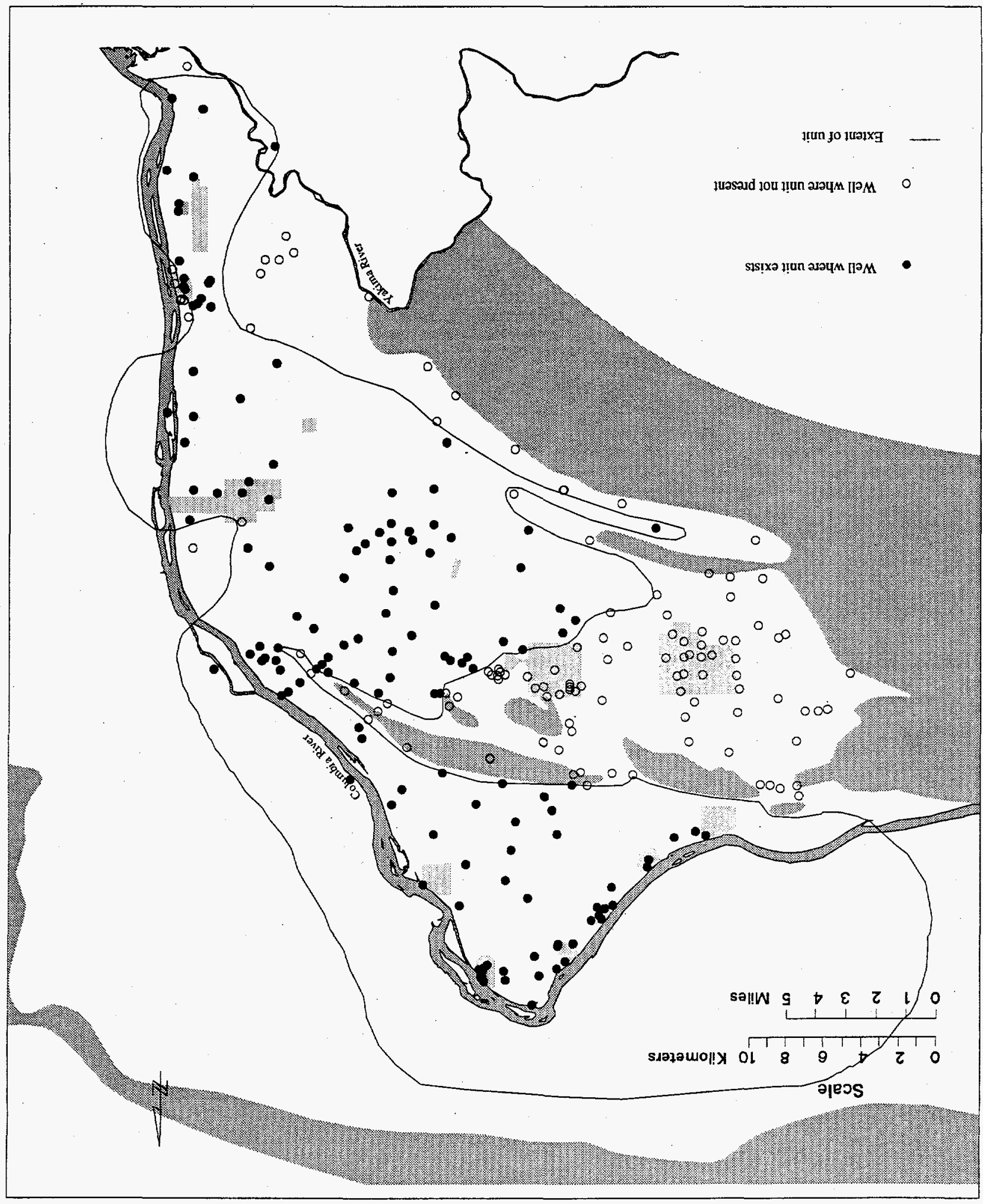




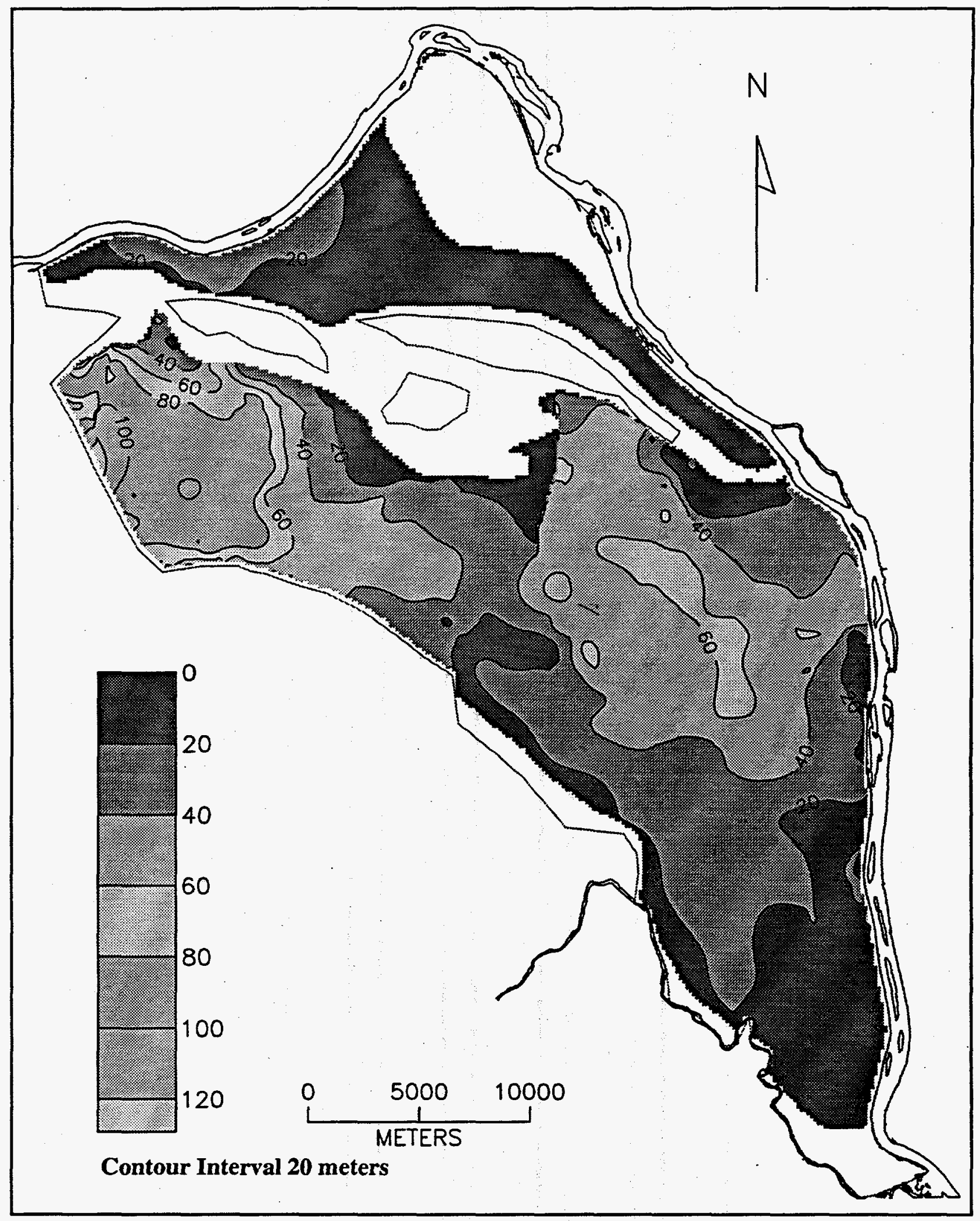

Figure 2.19. Isopach Map of Unit 5 


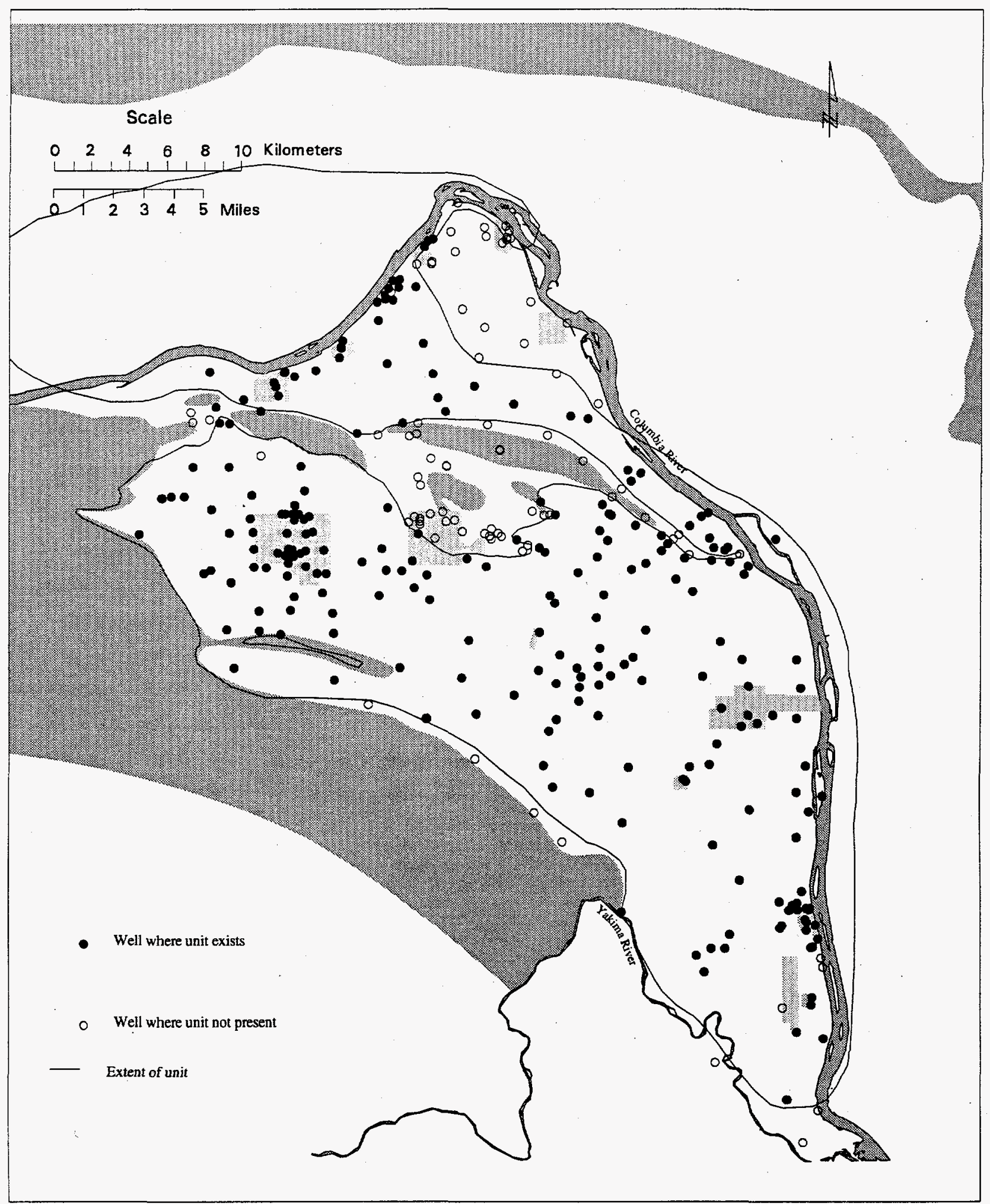

Figure 2.20. Distribution of Wells Where Unit 5 Was Identified 


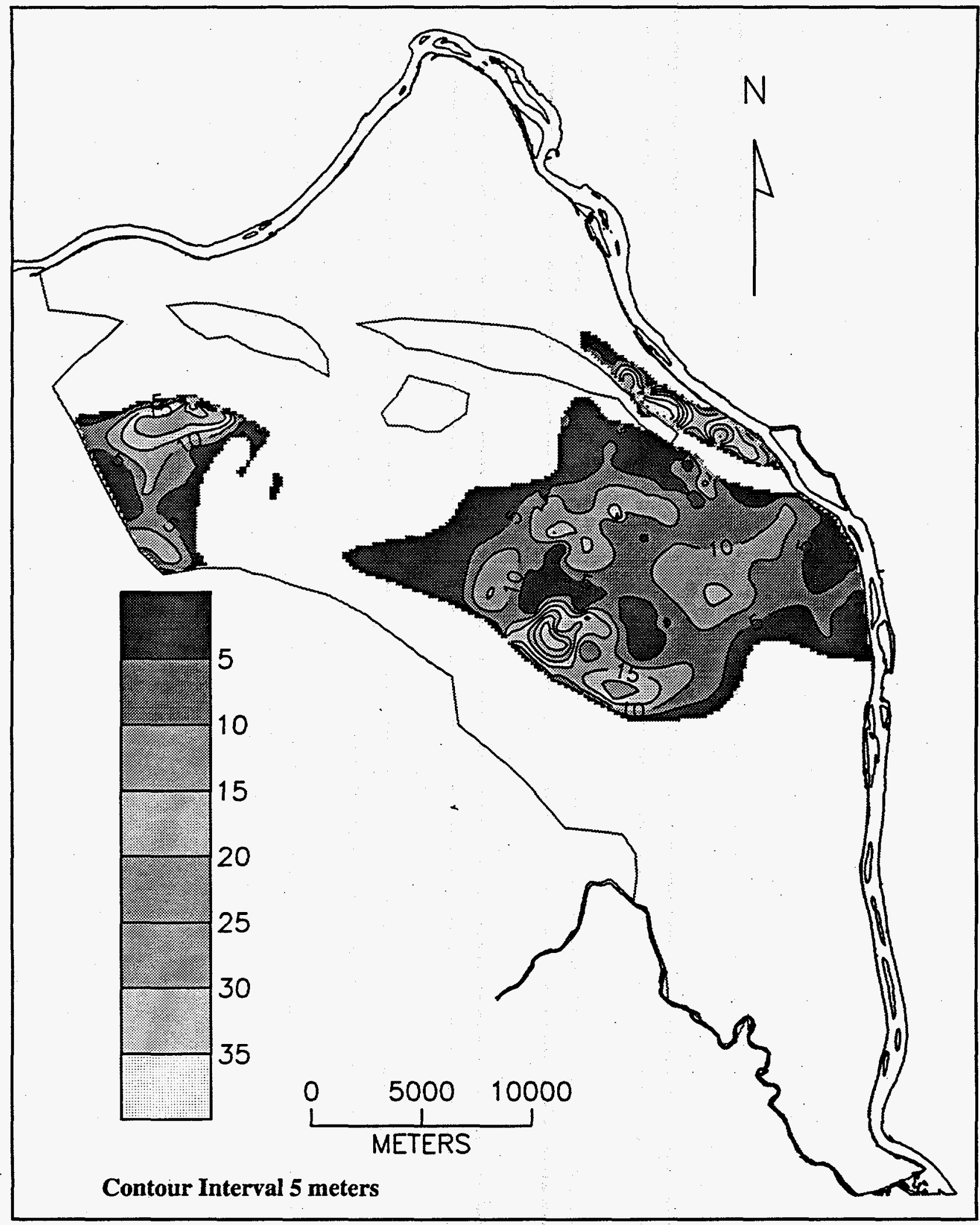

Figure 2.21. Isopach Map of Unit 4 


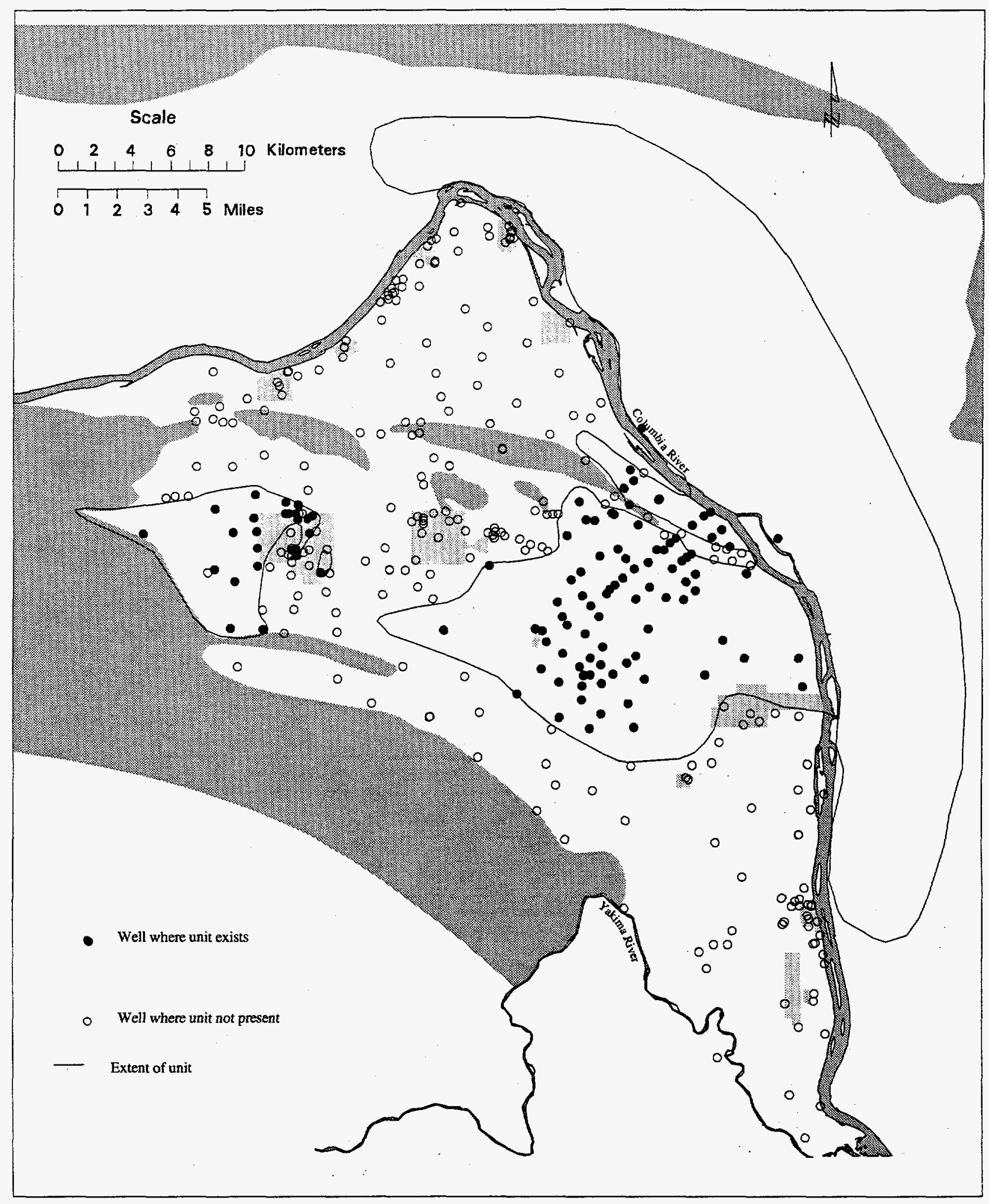

Figure 2.22. Distribution of Wells Where Unit 4 Was Identified 


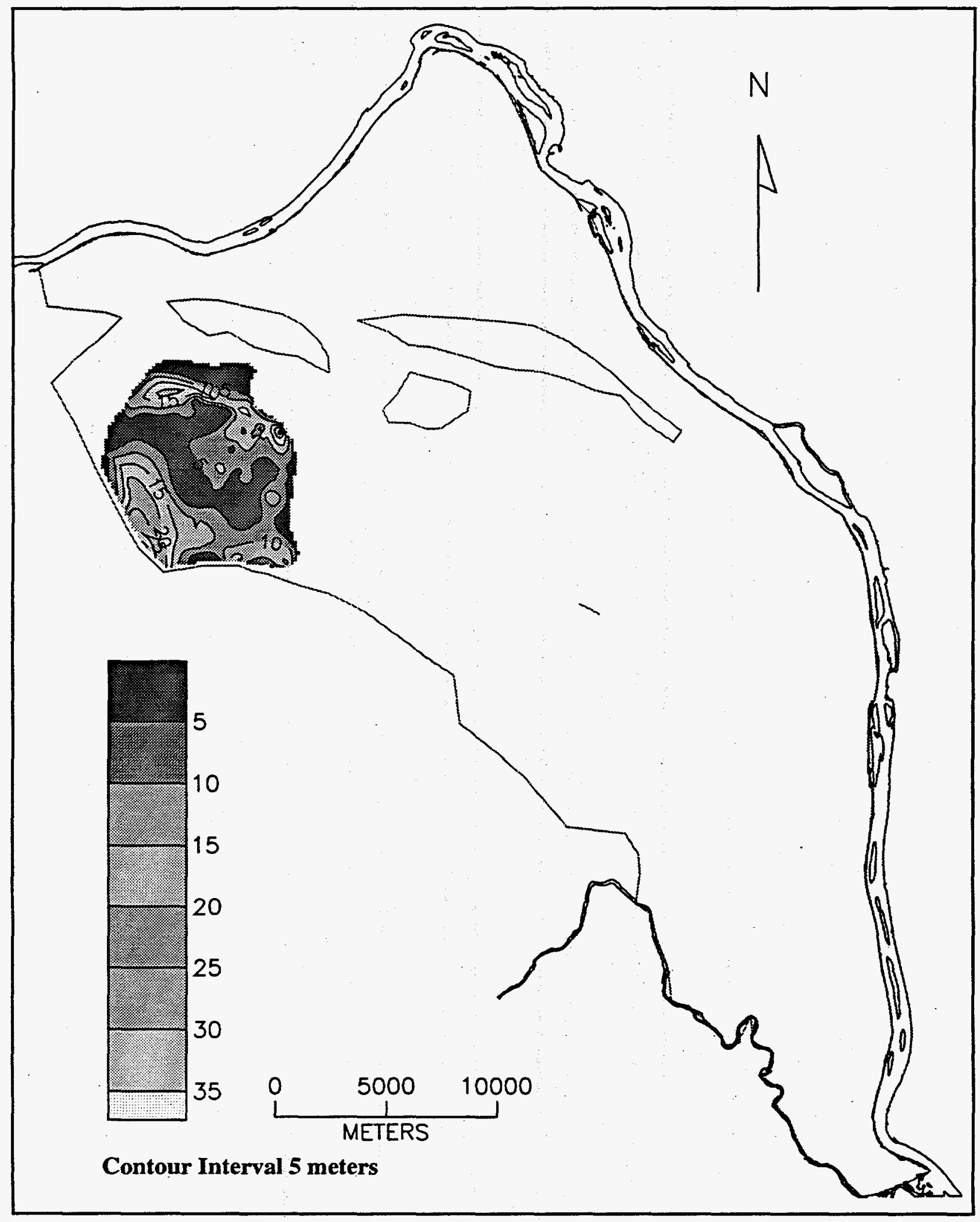

Figure 2.23. Isopach Map of Unit 3 


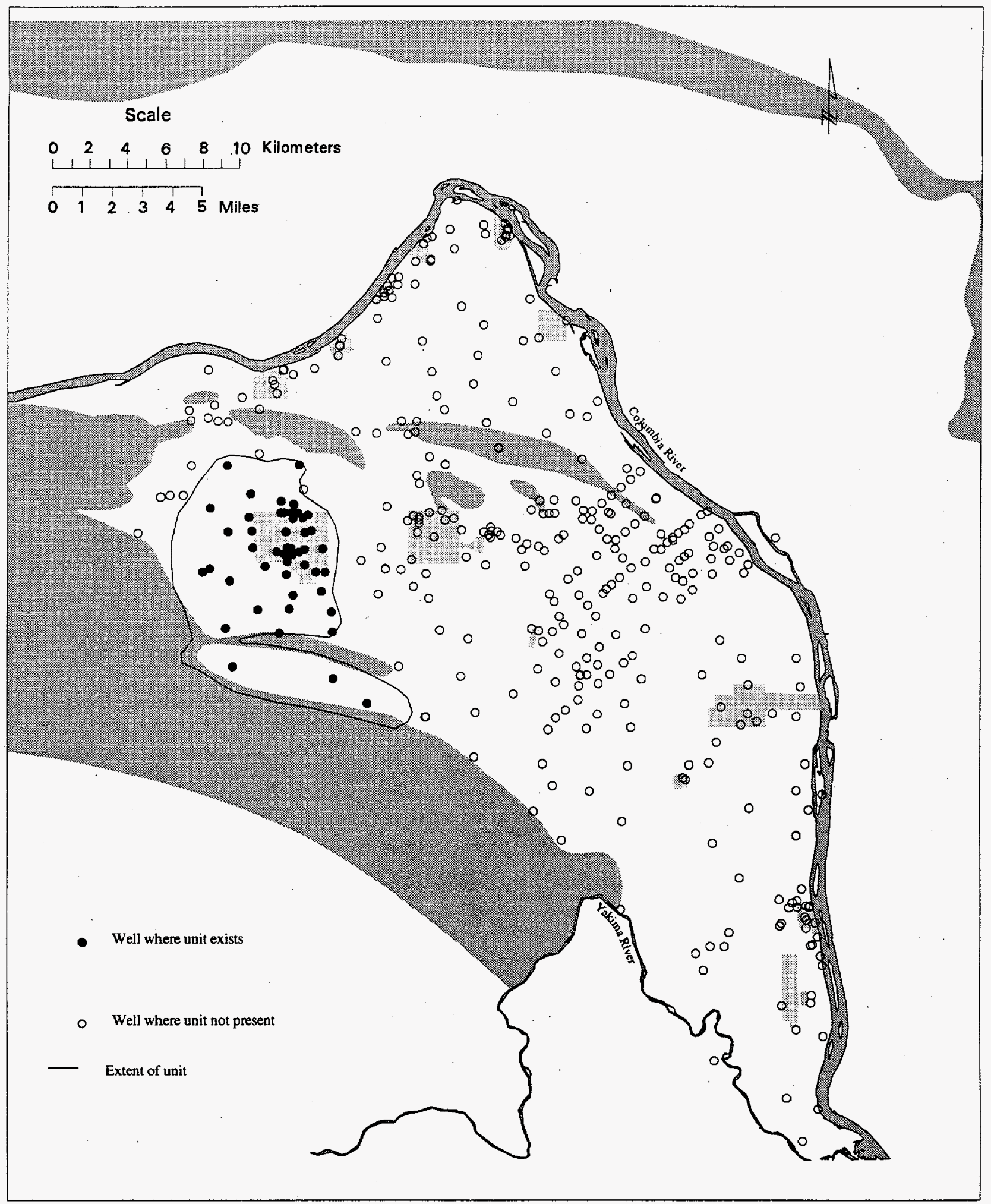

Figure 2.24. Distribution of Wells Where Unit 3 Was Identified 


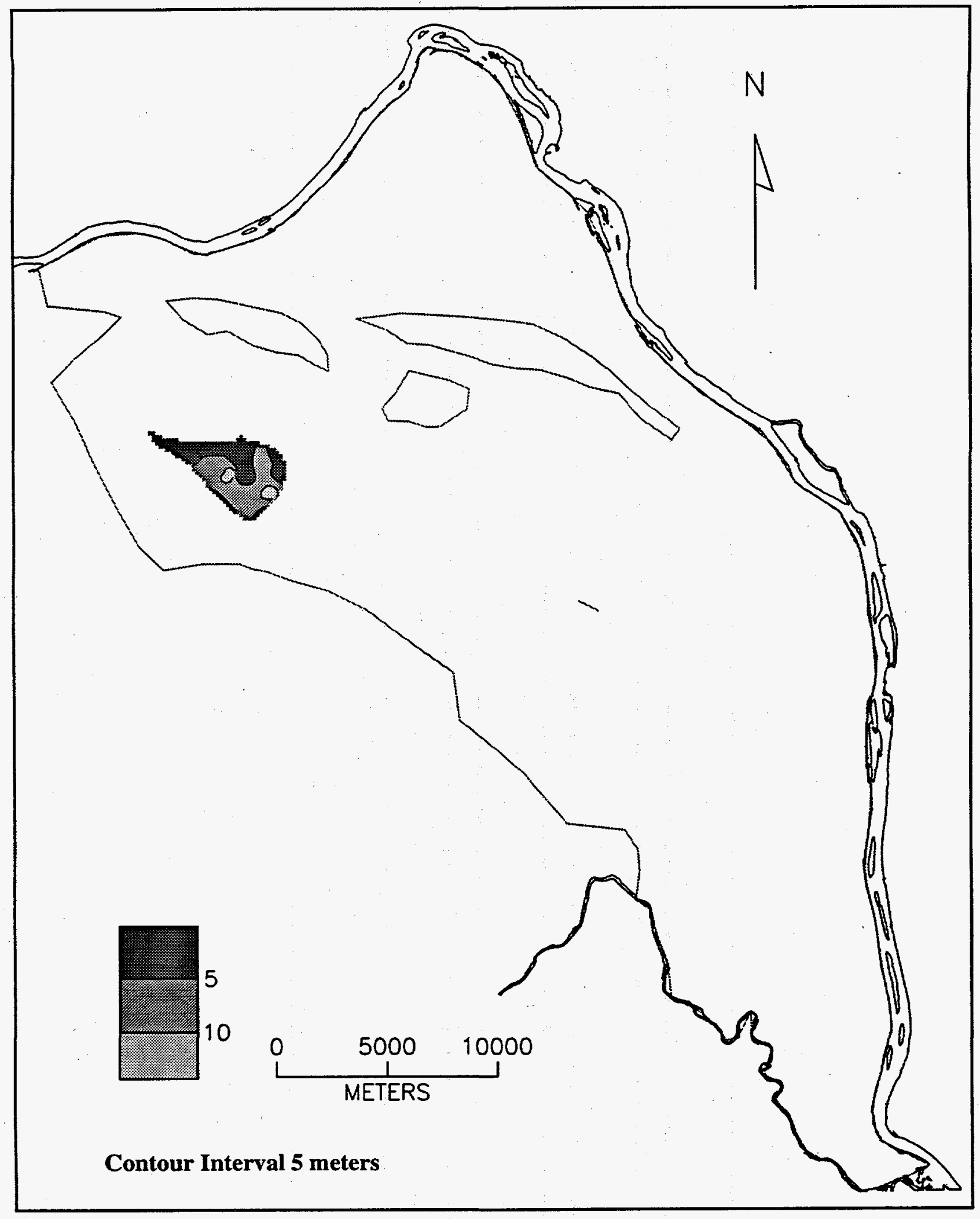

Figure 2.25. Isopach Map of Unit 2 


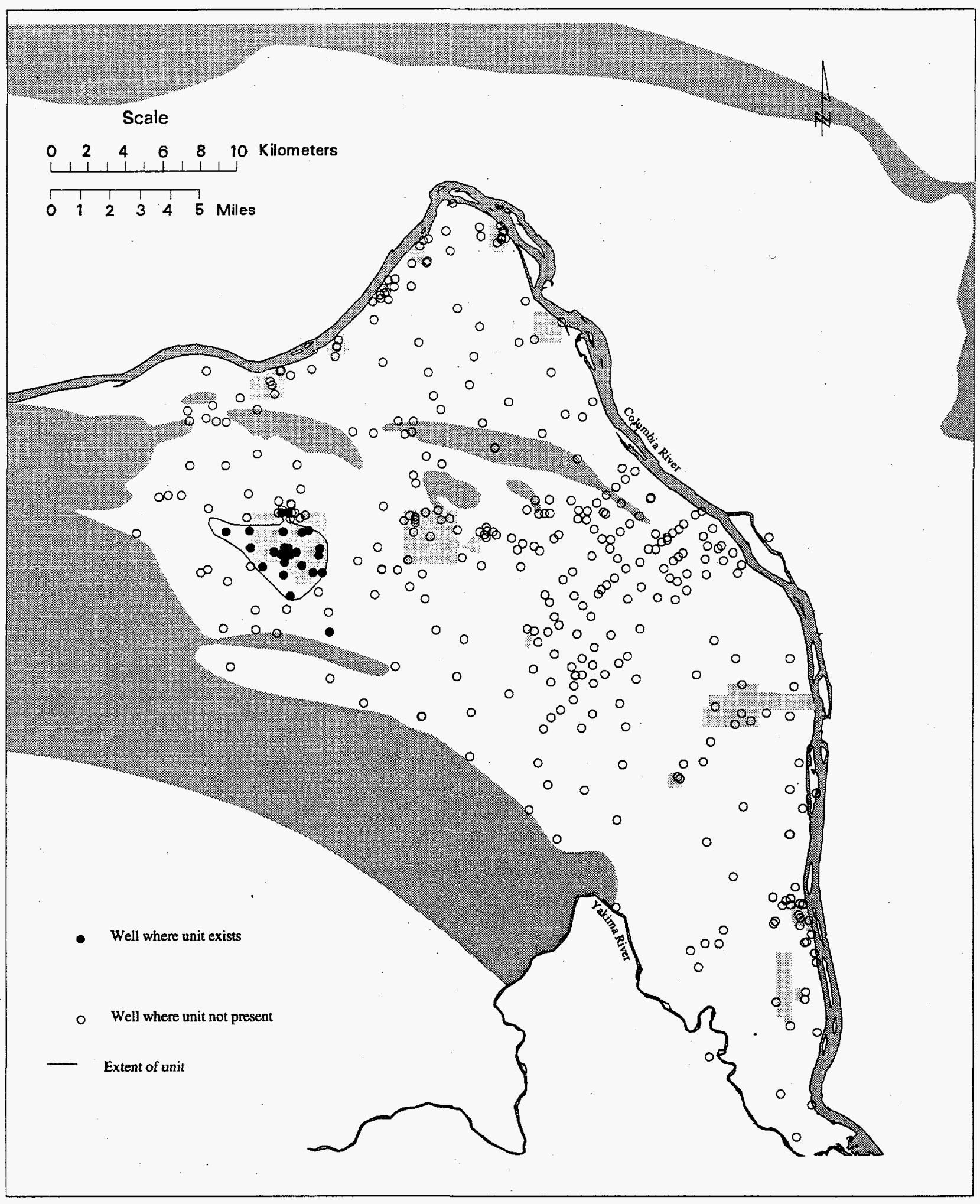

Figure 2.26. Distribution of Wells Where Unit 2 Was Identified 


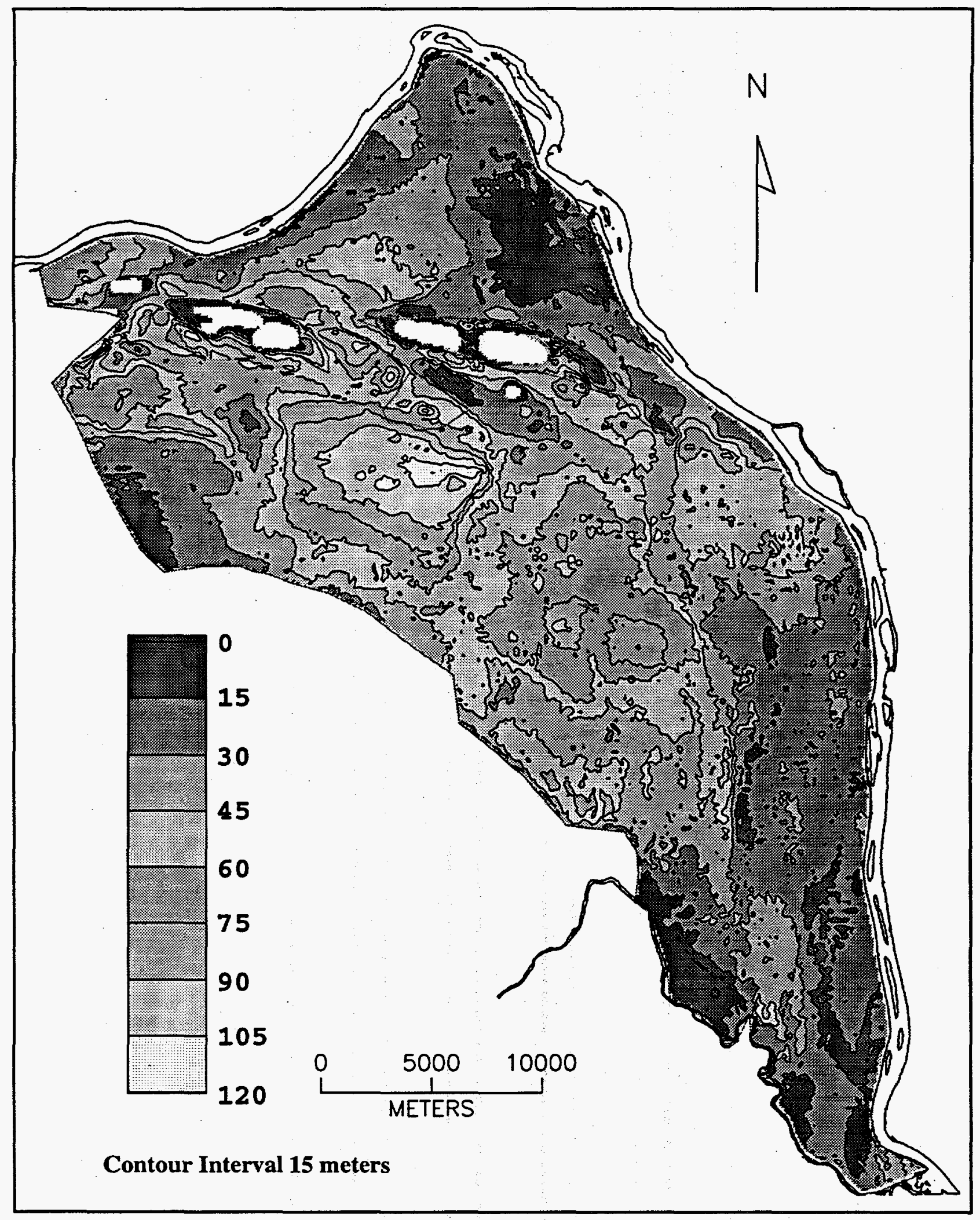

Figure 2.27. Isopach Map of Unit 1 


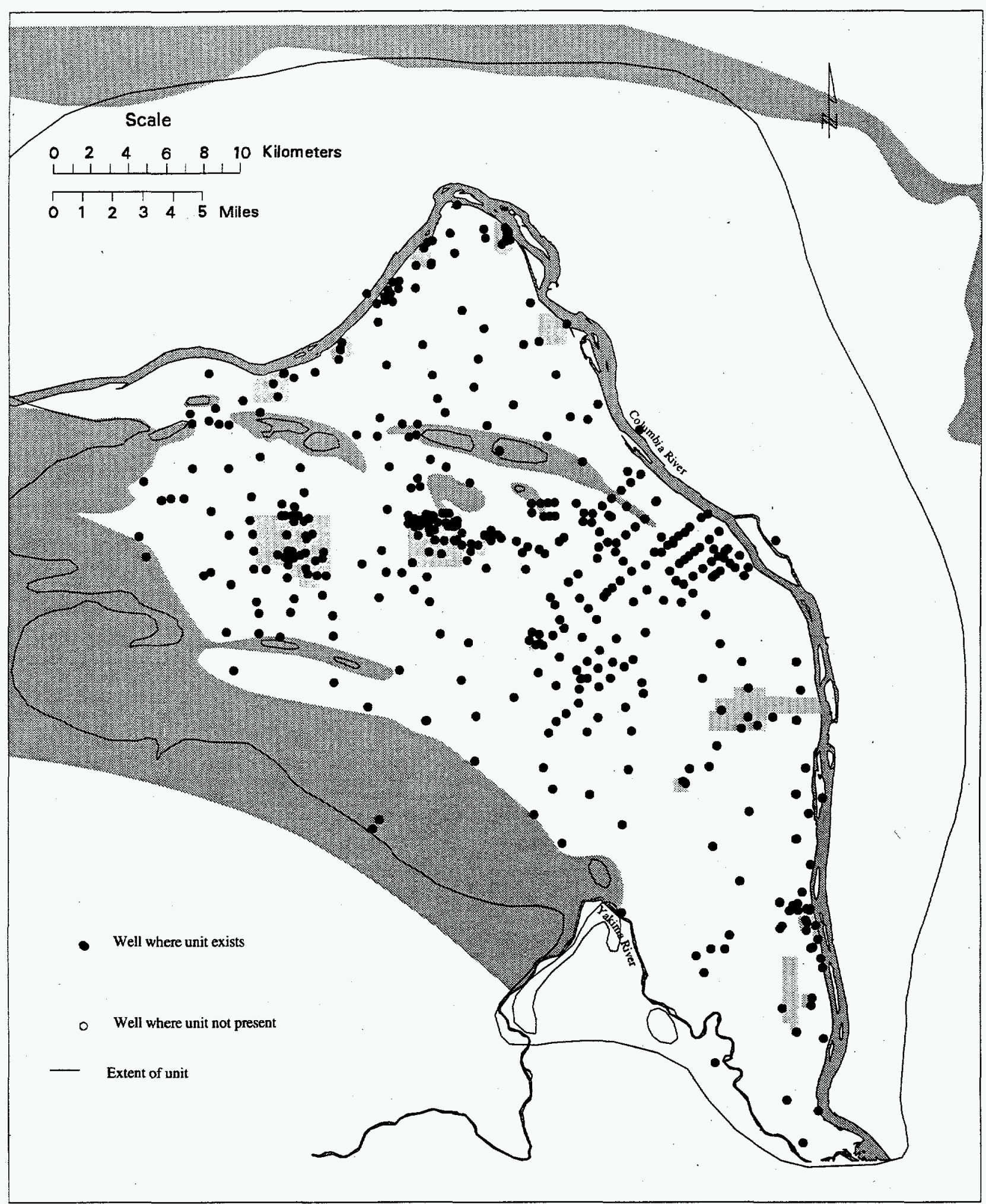

Figure 2.28. Distribution of Wells Where Unit 1 Was Identified 


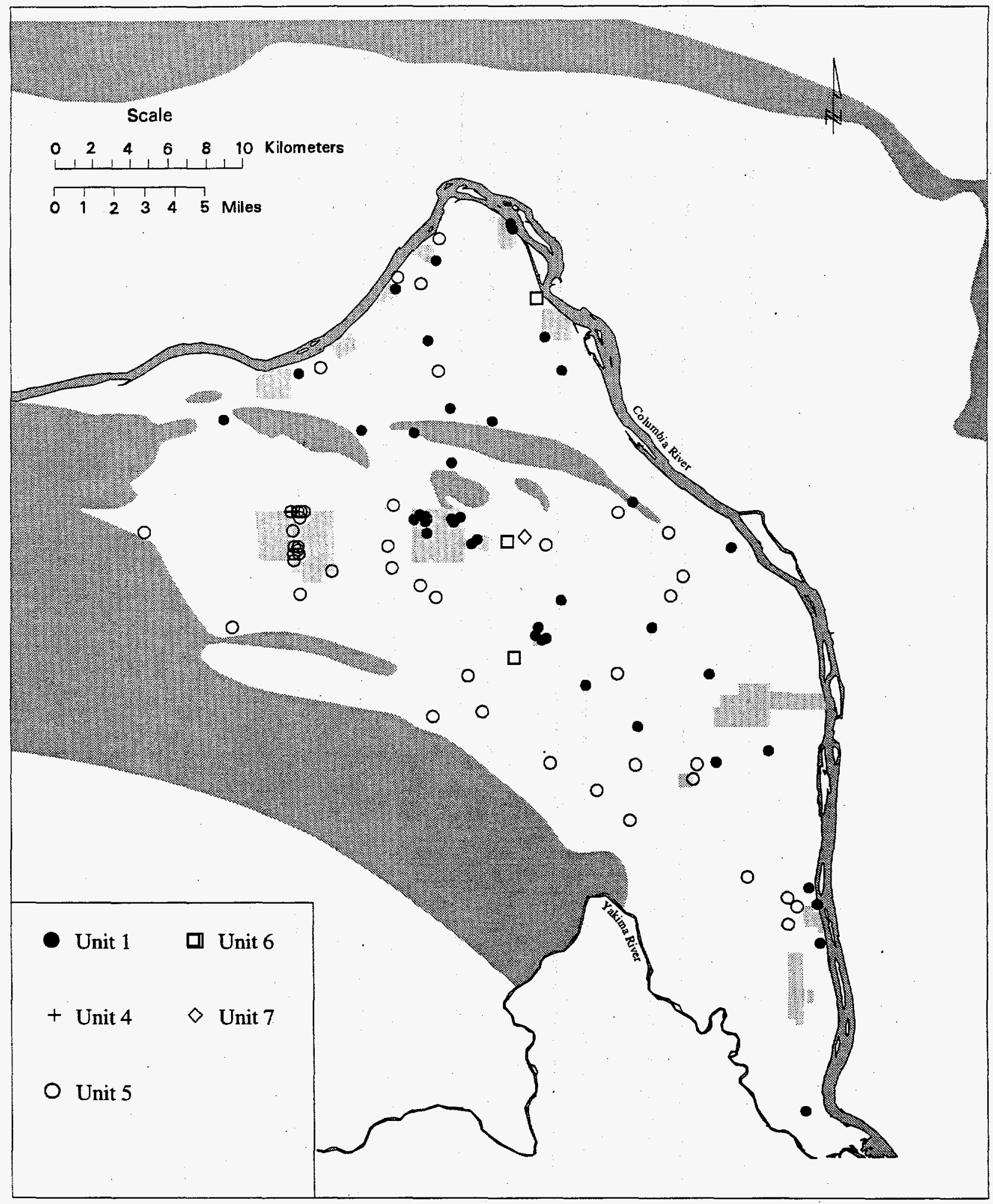

Figure 2.29. Distribution of Wells with Hydraulic Property Measurements for Different Units 


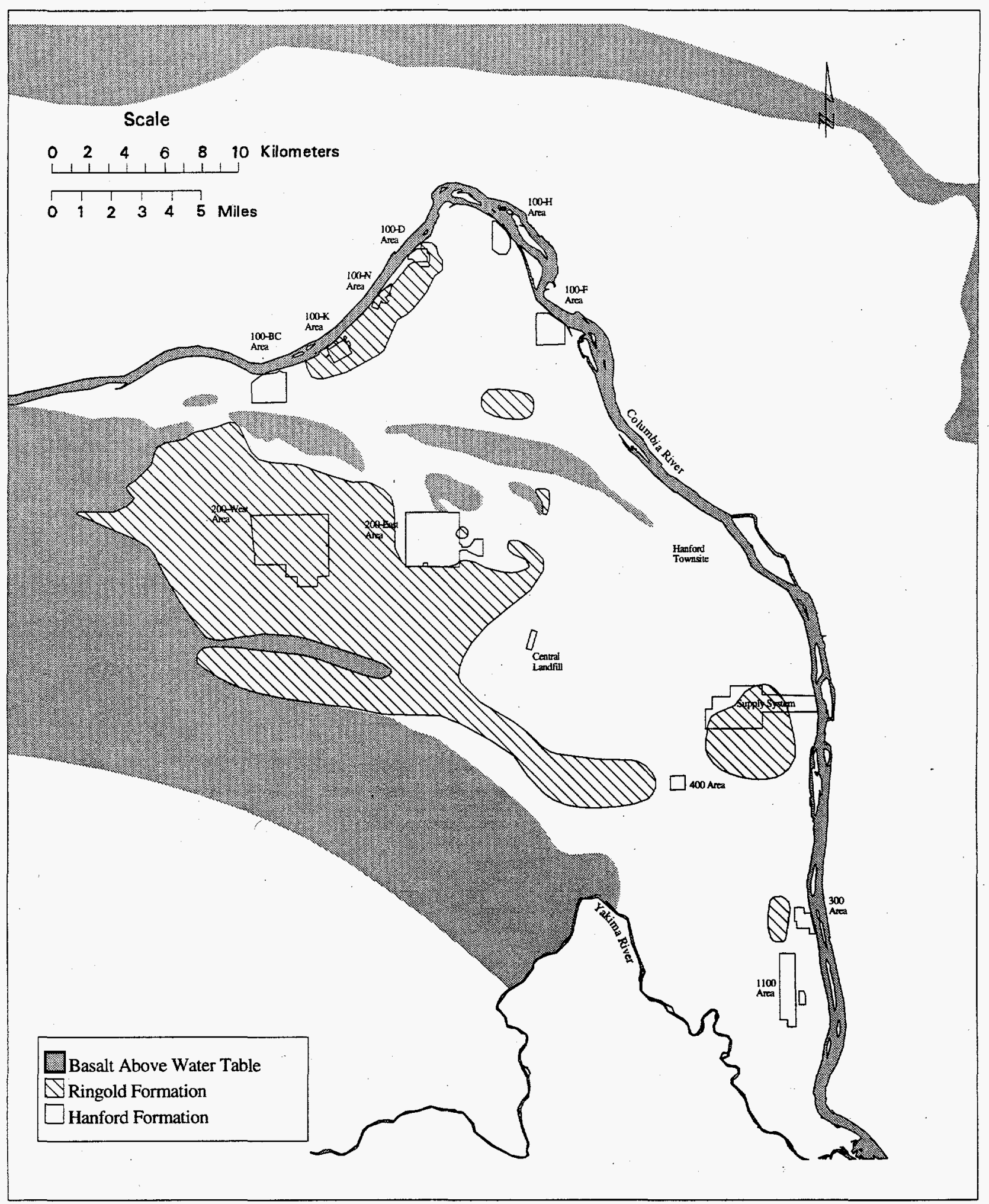

Figure 2.30. Geologic Units Present at the Water Table, June 1993 


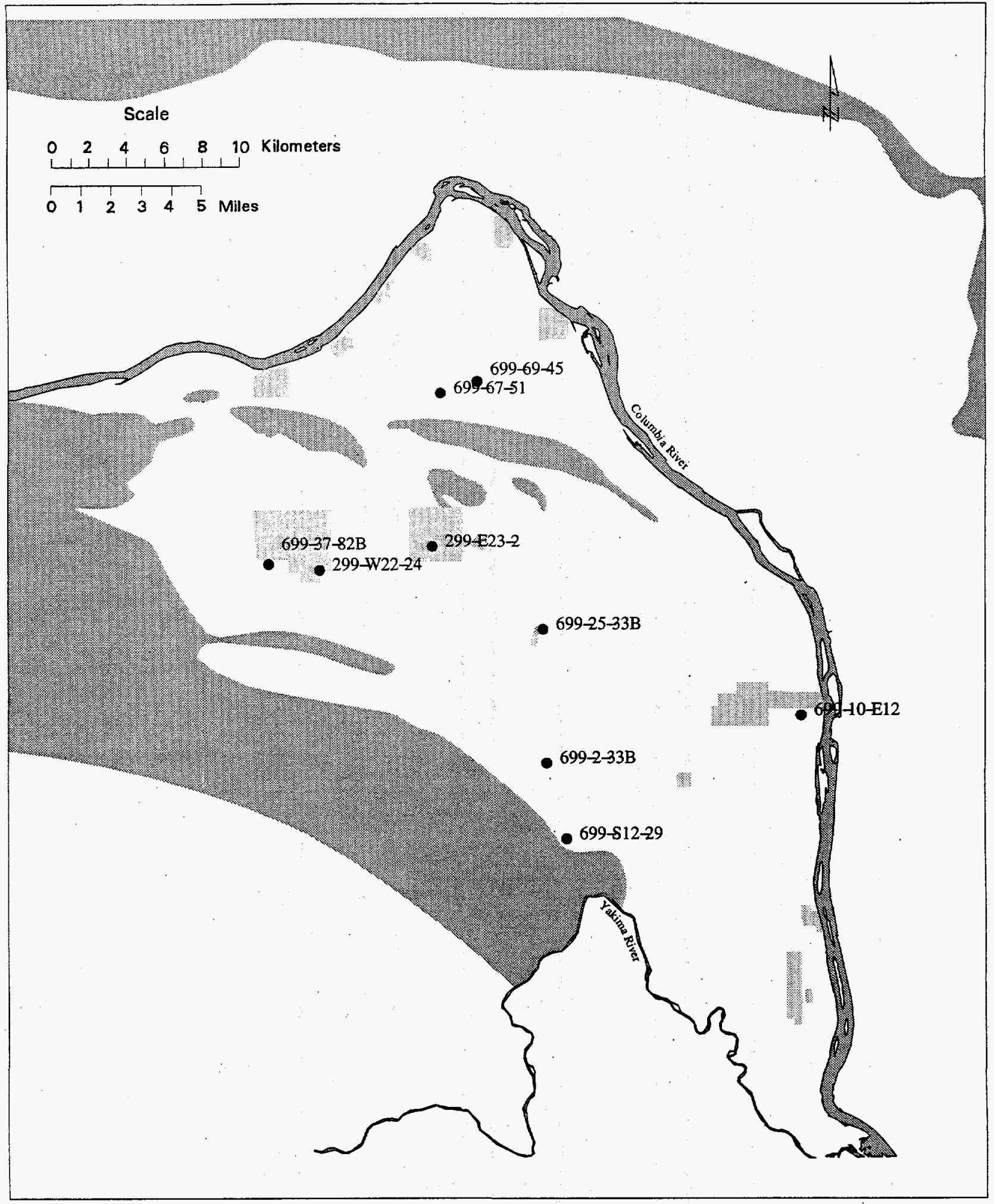

Figure 2.31. Map Showing Location of Selected Wells with Individual Piezometers 


\subsection{Inverse Calibration}

This section describes the inverse calibration method and its application to the Hanford Site unconfined aquifer. As background, previous calibration efforts for models of the unconfined aquifer are described.

\subsection{Description of Previous Model Calibrations}

As previously mentioned, the calibration routine applied by Cearlock et al. (1975) was used to calibrate the VTT model of the unconfined aquifer. The calibration routine was based on an equation obtained by numerical integration of the Boussinesq equation, which describes groundwater flow in unconfined aquifers along instantaneous streamlines of flow. The streamlines for the calibration procedure were based on a hand-contoured water-table map for 1973. A transmissivity value obtained from aquifer testing was supplied for each stream tube, which was defined by bounding streamlines. For stream tubes in which no transmissivity data were available, the spatial distribution of transmissivity was not calculated. In these portions of the model area, the transmissivity values were estimated by interpolation. The calibration yielded reasonable predicted water levels over most of the study area, generally within several feet of hand-contoured water levels. The steady-state calibration did not include any natural areal recharge but included the artificial recharge sources.

The hydraulic conductivity distribution and aquifer thickness of the VTT model were transferred to the CFEST model by interpolation of finite-difference values to finite elements. Transfer of data from the VTT model to CFEST did not include calibration of the CFEST model, although the predictions were close to observed because the VTT model was calibrated.

The inverse method developed by Neuman and Yakowitz (1979) and modified by Jacobson (1985) was applied to data from the unconfined aquifer to calibrate the CFEST model. This application and results are described in Jacobson and Freshley (1990). The steady-state inverse calibration was based on the finite-element grid and boundary conditions for the two-dimensional CFEST model. The best fit of the transmissivity distribution estimated with the inverse calibration was used in the CFEST model to simulate water-level changes from 1980 to 1985 . In general, the water levels predicted with CFEST and the transmissivity distribution from the inverse calibration 
more closely matched the observed water levels than predicted with the previously calibrated VTT model.

The current effort was undertaken to provide an updated calibration based on more recent estimates of surface recharge and the results of more recent hydraulic testing. In addition, the calibration was redone to be consistent with a new finite-element grid (Figure 3.1) and threedimensional model development effort described in this report. Knowledge gained from previous calibration efforts was used to guide the current effort, and much of the data used is the same. As characterization of the unconfined aquifer continues to expand our knowledge base, the calibration procedure should be periodically redone.

\subsection{Description of CFEST Inverse}

CFEST Inverse (CFEST-INV) is a stochastic hydrology code developed to augment CFEST for model calibration(d). It was designed to be compatible with CFEST and includes algorithms to calibrate the flow model to prior (measured) hydrogeologic parameters, such as head, boundary conditions, and prior measurements of transmissivity or hydraulic conductivity. The CFEST-INV code can be used as a single layer $\mathrm{x}-\mathrm{y}$ model or a multilayered $\mathrm{x}-\mathrm{z}$ or $\mathrm{x}-\mathrm{y}-\mathrm{z}$ model.

The CFEST-INV stochastic hydrology code currently uses the steady-state, isothermal, fluid pressure solution of the CFEST modeling package(d). The underlying mathematical equation for such systems is given by Poisson's equation for steady ground-water flow

$$
\nabla \cdot \mathbf{K} \nabla \mathbf{h}=\mathrm{q}
$$

subject to a generalized boundary condition

$$
-K \nabla h \cdot n=\alpha(h-H)+\beta Q
$$

(d) 1987 draft report, prepared for Battelle, Pacific Northwest Laboratory by ICF Northwest, Richland, Washington. 
where $\mathrm{K}$ is the hydraulic conductivity

$\mathrm{h}$ is the hydraulic head

$\mathrm{q}$ is the rate of fluid generation per unit area of aquifer

$\mathrm{n}$ is the unit normal to the boundary

$\nabla$ is the gradient operator

$\mathrm{H}$ is the prescribed head on the boundary

$Q$ is the flux prescribed on the boundary

$\alpha$ and $\beta$ describe the type of boundary conditions.

If $\alpha$ goes to infinity, Equation 3.2 becomes a Dirichlet (prescribed head) condition; if $\alpha$ becomes zero, Equation 3.2 becomes a Neumann (prescribed flux) condition; otherwise, Equation 3.2 is a Fourier (mixed) condition.

Discretizing the flow equation to finite elements results in a matrix equation

$$
\underline{\underline{A}} \underline{\mathrm{h}}=\underline{\mathrm{b}}
$$

where $\underline{\underline{A}}$ is an $\mathrm{n} \times \mathrm{n}$ global stiffness matrix

$\underline{h}$ is an $\mathrm{n} \times 1$ hydraulic head solution vector

$\underline{b}$ is the $\mathrm{n} \times 1$ load vector representing recharge, sources and sinks, and boundary conditions.

An element $a_{i j}$ of the A matrix represents a linear combination of the elemental hydraulic conductivities that surround a node:

$$
a_{i j}=\sum_{m=1}^{M} K_{m} w_{m}^{i j}
$$

where $\mathrm{K}_{1}, \ldots, \mathrm{K}_{\mathrm{m}}$ are the elemental hydraulic conductivities and $\mathrm{w}_{1} \mathrm{ij}, \ldots, \mathrm{w}_{\mathrm{m}} \mathrm{ij}$ are the weights. The weights are determined by discretization of Equation 3.1. The discretization used in CFEST is a quadrilateral or triangular element scheme.

A goal of ground-water flow modeling is to determine the proper input parameter values (specifying A and B) so that the predicted hydraulic head 


$$
\underline{h}=\underline{\underline{A}}^{-1} \underline{b}
$$

matches a preconceived or prior hydraulic head distribution as closely as possible. The CFESTINV algorithm uses non linear regression and adjoint algorithms to select an optimal parameter distribution so that the predicted hydraulic head distribution matches a prior, kriged head distribution from the least-squares perspective.

The goal of flow model calibration is to identify optimal values of input parameters so that a "goodness of fit" function is minimized(d). The statistical inverse method is based on prior information on transmissivities as well as observed hydraulic heads. Prior information on transmissivities may include estimates based on aquifer testing and estimates of aquifer thickness from geologic information. The spatial distribution of transmissivity determined by the statistical inverse method produces hydraulic heads that are reasonably close to observed heads keeping inverse estimates of transmissivity close to prior estimates.

Statistical information on prior estimates of transmissivity and hydraulic head can be obtained by kriging. The kriging method has been used by Clifton and Neuman (1982) and Jacobson (1985) to interpolate transmissivity and hydraulic head data to estimate values at node points with no observations and associated estimation errors. The kriged estimates of transmissivity are used as prior information, while the kriged estimates of hydraulic head are used as "observed" heads for the inverse method. Including statistical information about the prior estimates of transmissivity and kriged hydraulic heads in the inverse method allows a statistically calibrated ground-water flow model. If no prior statistical information is available, the inverse method can still be applied; however, the result is not considered a statistically calibrated flow model.

\subsection{Development of the Inverse Model}

Application of the inverse method to calibrate a two-dimensional model of the Hanford Site unconfined aquifer required preparation of input data. Because the method is applied only to steady-state conditions, an appropriate time period was selected when artificial discharges to the aquifer and corresponding water-level changes were relatively constant. Once the time period was selected, data representative of that period were prepared for input, including hydraulic heads, transmissivities, boundary conditions, artificial recharge, and natural recharge. 


\subsubsection{Selection of Steady-State Time Period}

For this calibration effort, the same steady-state time period selected by Jacobson and Freshley (1990) was used. They reviewed cooling water discharge information at the major disposal facilities within the 200-East and 200-West Areas and determined that, compared with other periods of time, the discharges remained relatively constant from 1976 to 1979. In addition, they found water levels in wells monitoring the unconfined aquifer near these disposal facilities were also relatively constant. Based on the available data, Jacobson and Freshley (1990) selected 1979 as the most appropriate time for the inverse calibration because it represented the closest approximation to steady-state conditions within recent Hanford operations. Water-level measurements collected in December 1979 were selected for the inverse calibration because these data were closer to the end of the steady-state period than data collected in June of that year. In addition, the influence of changing Columbia River level was less in December when the river was lower.

\subsubsection{Hydraulic Head Data Preparation}

Water-level data collected in December 1979 were reviewed for trends and outliers. Waterlevel measurements from wells that were obvious outliers or from wells strongly influenced by changes in river stage were not used in the inverse calibration. A few wells were not included because their screened intervals were open to a large portion of the unconfined aquifer and these measurements may not reflect the water table, particularly where vertical gradients may occur such as near artificial recharge facilities or near the river. The resulting observed (measured) water-table map used for the inverse calibration is shown in Figure 3.2.

To apply the statistical inverse method to the Hanford Site unconfined aquifer, interpolated hydraulic heads and their associated estimation errors at all node points are needed as input data. Jacobson and Freshley (1990) tried unsuccessfully to apply kriging to the hydraulic heads, but kriged estimates of hydraulic heads could not be obtained when the entire study area was considered because of the complex nature of the hydraulic head distribution. The large volumes of cooling water discharged to the ground, large variations in transmissivity, and flat hydraulic gradients made it difficult to define a semivariogram for the distribution of hydraulic head. Definition of a semivariogram is required for kriging to be applied. The distribution of hydraulic 
head in Figure 3.2 were interpolated to node points of the finite-element grid (Figure 3.1) with ARC/INFO. Because the hydraulic heads were not kriged, the statistical aspects of the inverse

calibration were not considered and, therefore, a statistically calibrated flow model could not be produced.

\subsubsection{Transmissivity Data Preparation}

In the finite-element approach used by CFEST, aquifer properties such as transmissivity or hydraulic conductivity are assumed to be constant in each element. If several elements have the same transmissivity, they are treated as a zone of constant transmissivity. Transmissivity values obtained from aquifer tests are generally viewed as point measurements because they represent an average value near the well. In addition to the aquifer tests used in the previous inverse calibration (Jacobson and Freshley 1990), new data were included in this calibration. The new information incorporated are from Thorne and Chamness (1992), Thorne et al. (1993), Thorne and Newcomer (1992), and Thorne et al. (1994). In addition, the results of very recent tests, whose results have not been published, were included in this calibration.

As with Jacobson and Freshley (1990), the number of available transmissivity measurements was insufficient to attempt kriging. The distribution of transmissivity from the previous inverse calibration, which also reflects the distribution used in the VTT model (Cearlock et al. 1975), was adapted as an initial estimate. The transmissivity distribution based on not including natural recharge was used as an initial condition because this is the distribution that has been used in recent modeling (Wurstner and Devary 1993; Wurstner and Freshley 1994). Where measurements were available, they were used to adjust the transmissivity zones in the calibration. The wells and aquifer test results used in the inverse calibration are shown in Figure 3.3.

A zonation pattern for the new finite-element grid (Figure 3.1) was developed to be similar to the zonation pattern used by Jacobson and Freshley (1990) for the old CFEST model grid. They developed their zonation pattern based on the distribution of transmissivities in the VTT model. The zonation pattern reflects areas of similar transmissivity values. The zonation pattern and ranges of the initial estimates of transmissivity used in the inverse calibration are shown in Figure 3.4. In this application of CFEST-INV, there were 262 different transmissivity zones. Zonation of a model grid for purposes of model calibration is a trade-off between having sufficient zones to describe the 
variation in transmissivity for the aquifer being modeled and having too many zones for the inverse calibration to be able to reach a solution, both in terms of efficiency and stiffness of the problem.

\subsubsection{Boundary Condition Input}

Boundary conditions for the inverse calibration are the same as those applied to the CFEST model using the revised grid. Prescribed head conditions were assumed along the Columbia River and Yakima River boundaries. The prescribed head was equal to the yearly average river level at each boundary node during 1979. These data were interpolated to the new finite-element grid with ARC/INFO. Prescribed head of $147 \mathrm{~m}$ was specified at the model boundary in the Cold Creek Valley. The contribution from spring discharges along the northeast side of Rattlesnake Mountain and Dry Creek Valley was accounted for by specified flow rates. This value was $1333 \mathrm{~m} 3 / \mathrm{day}$. No-flow conditions were assumed in areas where the aquifer is bordered by basalt outcrops and subcrops (basalt intersecting the water table) near Gable Mountain and Gable Butte.

\subsubsection{Artificial Recharge Input}

Estimates of waste water discharged to the ground in 1979 for this inverse calibration were the same as those applied in Jacobson and Freshley (1990). This information is documented annually by the management and operations contractor at the Hanford Site. Jacobson and Freshley (1990) corrected the discharge estimates based on comparison of inflow to the operating areas with discharges to the major disposal facilities. The resulting discharge estimates used in the inverse calibration are listed in Table 3.1.

\subsubsection{Natural Areal Recharge Input}

The previous application of the inverse method by Jacobson and Freshley (1990) demonstrated that including natural recharge provided the best calibration. In that effort, an initial distribution of recharge based on vegetation patterns and elevation was used. Recently, Fayer and Walters (1995) estimated recharge rates across the Hanford Site to use in this calibration of the sitewide model. They used available information about recharge from measurements of drainage, water content, and tracers as well as computer modeling of water balance to develop the recharge estimates. These estimates were assigned to specific soil-vegetation combinations and distributed across the Hanford Site using a soil map and a vegetation/land use map. The recharge map 
Table 3.1. Summary of Major Discharges to the Ground at Facilities in the 200-East and 200West Areas, 1979

\begin{tabular}{|c|c|}
\hline Facilities & Discharge $(\mathrm{m} 3 / \mathrm{d})$ \\
\hline \multicolumn{2}{|l|}{ 200-West Area } \\
\hline U Pond (216-U-10) & 4390 \\
\hline $216-\mathrm{T}-1$ & 32 \\
\hline $216-T-4-2$ & 52 \\
\hline $216-S-10$ & 543 \\
\hline $216-S-19$ & 162 \\
\hline $2101-\mathrm{M}$ & 14 \\
\hline \multicolumn{2}{|l|}{ 200-East Area } \\
\hline Gable Mountain Pond (216-A-25) & 33,100 \\
\hline B Pond (216-B-3) & 11,500 \\
\hline 216-A-30, 216-A-37-1 & 536 \\
\hline $216-\mathrm{B}-55,216-\mathrm{B}-62$ & 604 \\
\hline $216-\mathrm{B}-63$ & 719 \\
\hline \multicolumn{2}{|l|}{ Other Areas } \\
\hline 100-D Septic Tanks & 9 \\
\hline 100-F Septic Tanks & 2 \\
\hline 100-K Septic Tanks & 4 \\
\hline $124-\mathrm{N}-10$ & 65 \\
\hline $1301-\mathrm{N}$ & 13,042 \\
\hline 300 Area Ash Disposal Pits & 153 \\
\hline 300 Area Process Trenches & 12,000 \\
\hline $4608 \mathrm{~B} / \mathrm{C}$ & -120 \\
\hline North Richland Well Field & 14,800 \\
\hline
\end{tabular}


(Figure 2.5) reflects current conditions. Some vegetation changes have occurred between 1979 and 1985, mainly resulting from grass fires. However, current conditions are sufficiently close to 1979 conditions that the recharge estimates were used. The recharge estimates provided by Fayer and Walters (1995) were interpolated to the finite element grid with ARC/INFO (Figure 3.5).

\subsection{Inverse Calibration Results}

The inverse calibration required a number of attempts to reach a solution. Initially, the resulting heads predicted with the transmissivity distribution were 2 to $4 \mathrm{~m}$ too high over the entire aquifer. However, the transmissivities used as prior values for the calibration used a different distribution of the natural recharge applied across the Site. To obtain a solution, the initial transmissivities were increased by a factor of 10 to balance the recharge. When this was done, a solution was reached in 131 iterations. The inverse calibration reduced water level variations at node points (i.e., the average residual sum of squares corresponding to predicted versus measured hydraulic head) from $3.2 \mathrm{~m}$ to $0.7 \mathrm{~m}$, calculated from the initial and inverse estimates of transmissivity, respectively. The transmissivity distribution obtained from the inverse solution is shown in Figure 3.6. The comparison of heads predicted with the inverse transmissivities and the observed water levels for 1979 is shown in Figure 3.7.

The inverse transmissivities vary from less than $250 \mathrm{~m}^{2} / \mathrm{d}$ to more than $500,000 \mathrm{~m}^{2} / \mathrm{d}$. The average value is $127,709 \mathrm{~m} 2 / \mathrm{d}$. The histogram of transmissivity values from the inverse calibration is shown in Figure 3.8. 


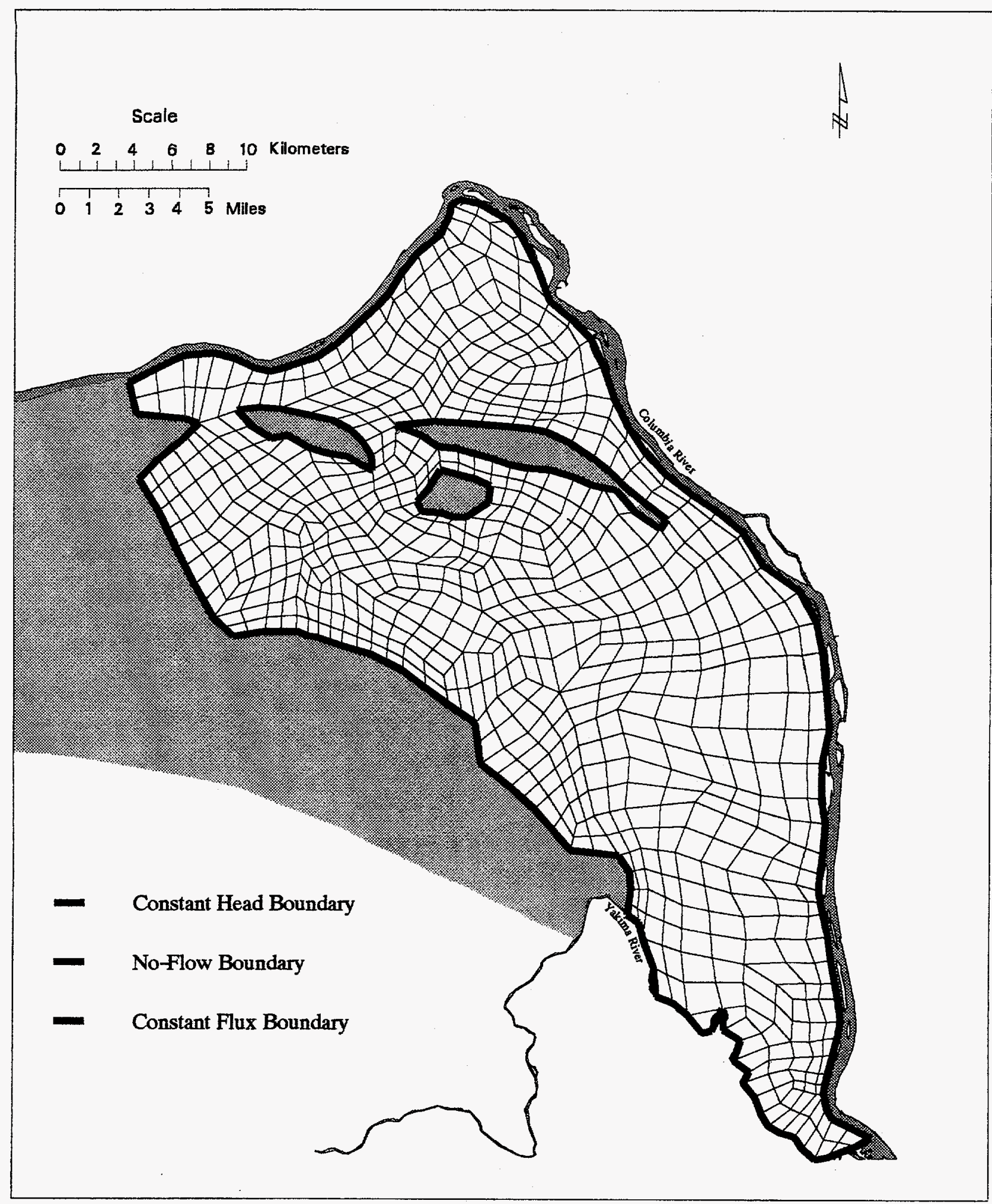

Figure 3.1. Finite-Element Grid Showing Boundary Conditions 


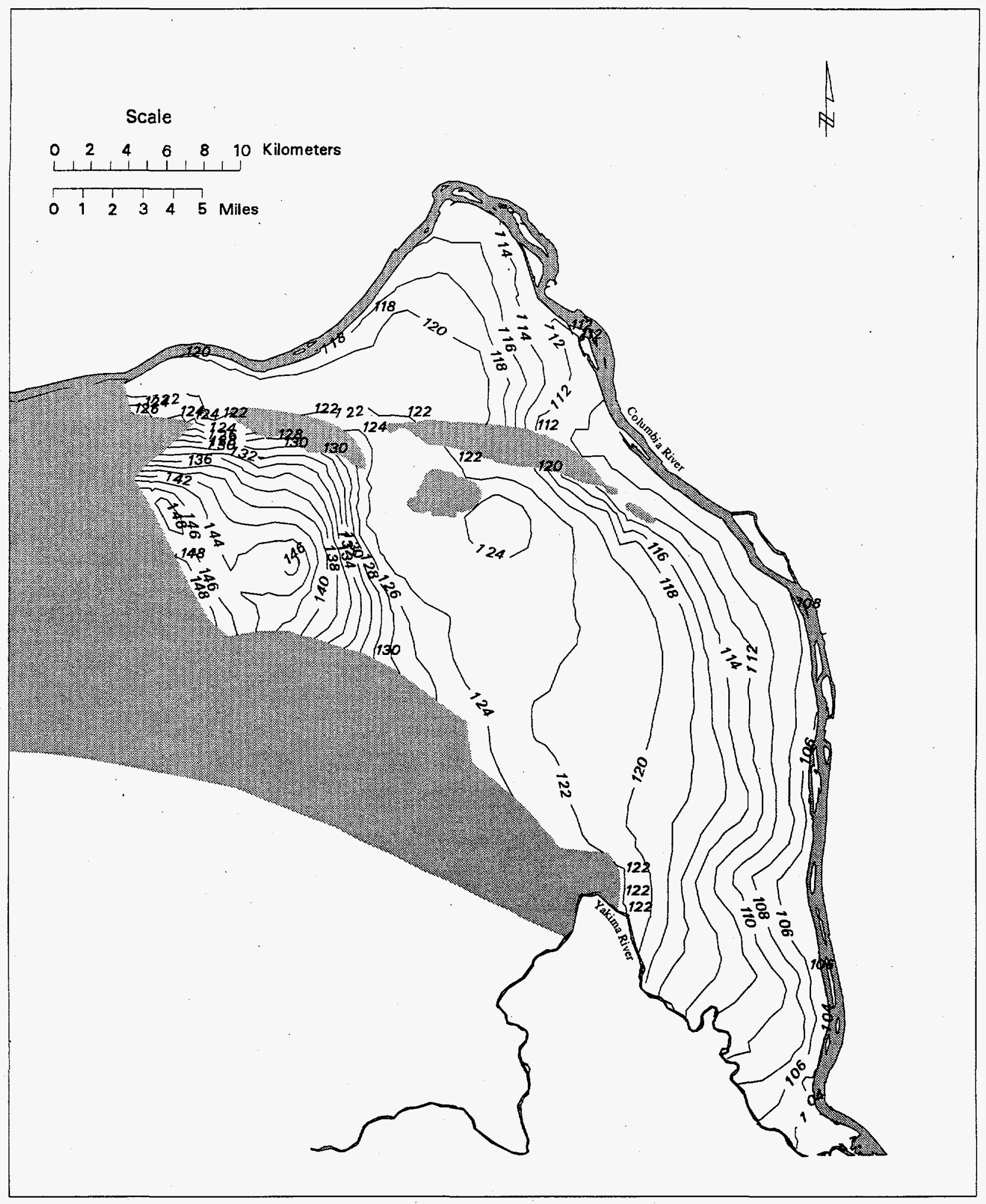

Figure 3.2. Observed (Measured) Water-Level Distribution Used in the Inverse Calibration 


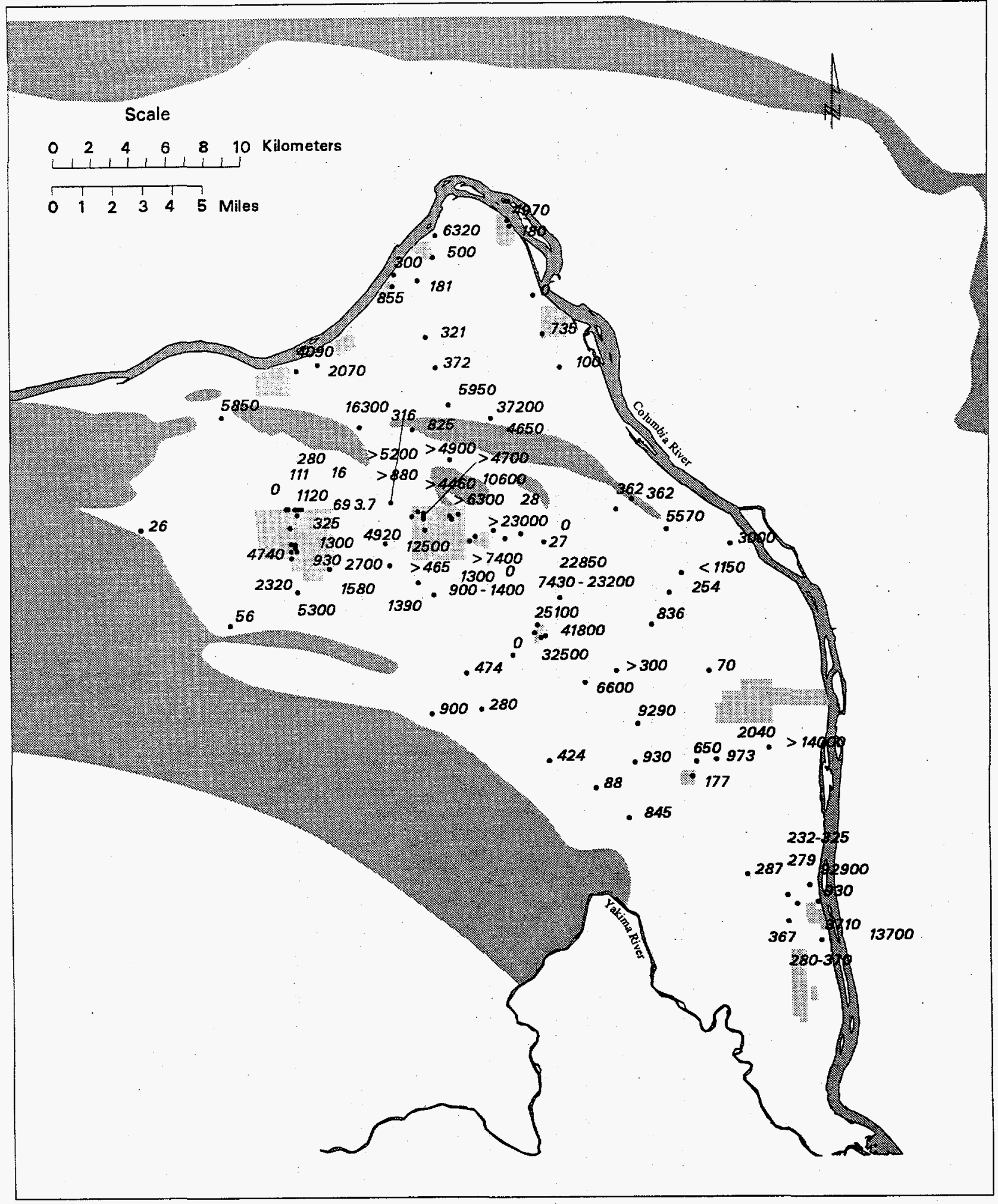

Figure 3.3. Wells and Aquifer Test Results (Transmissivities in $\mathrm{m}^{2} / \mathrm{d}$ ) Used in the Inverse Calibration 


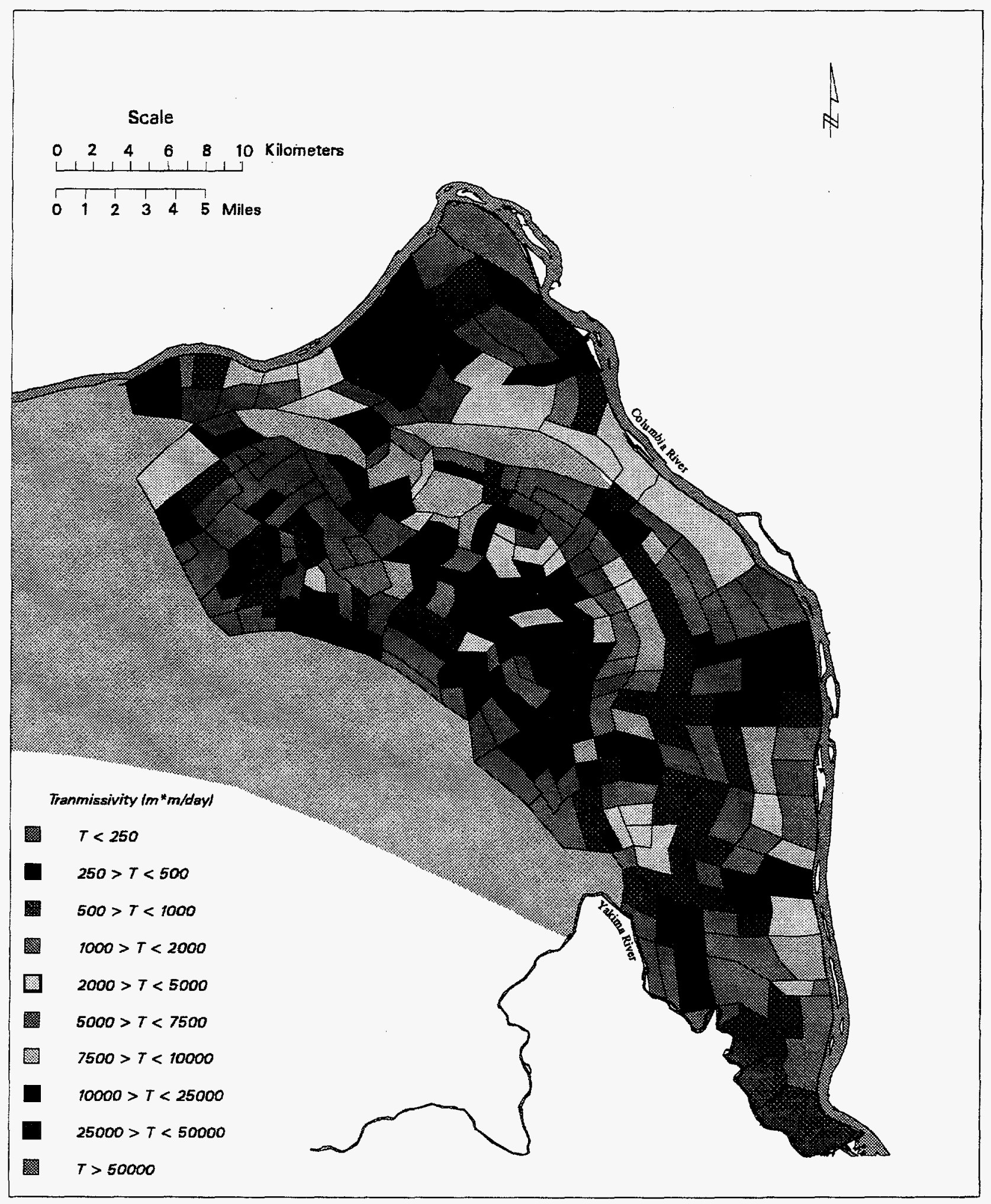

Figure 3.4. Transmissivity Zonation Used in the Inverse Calibration 
-

-

- 


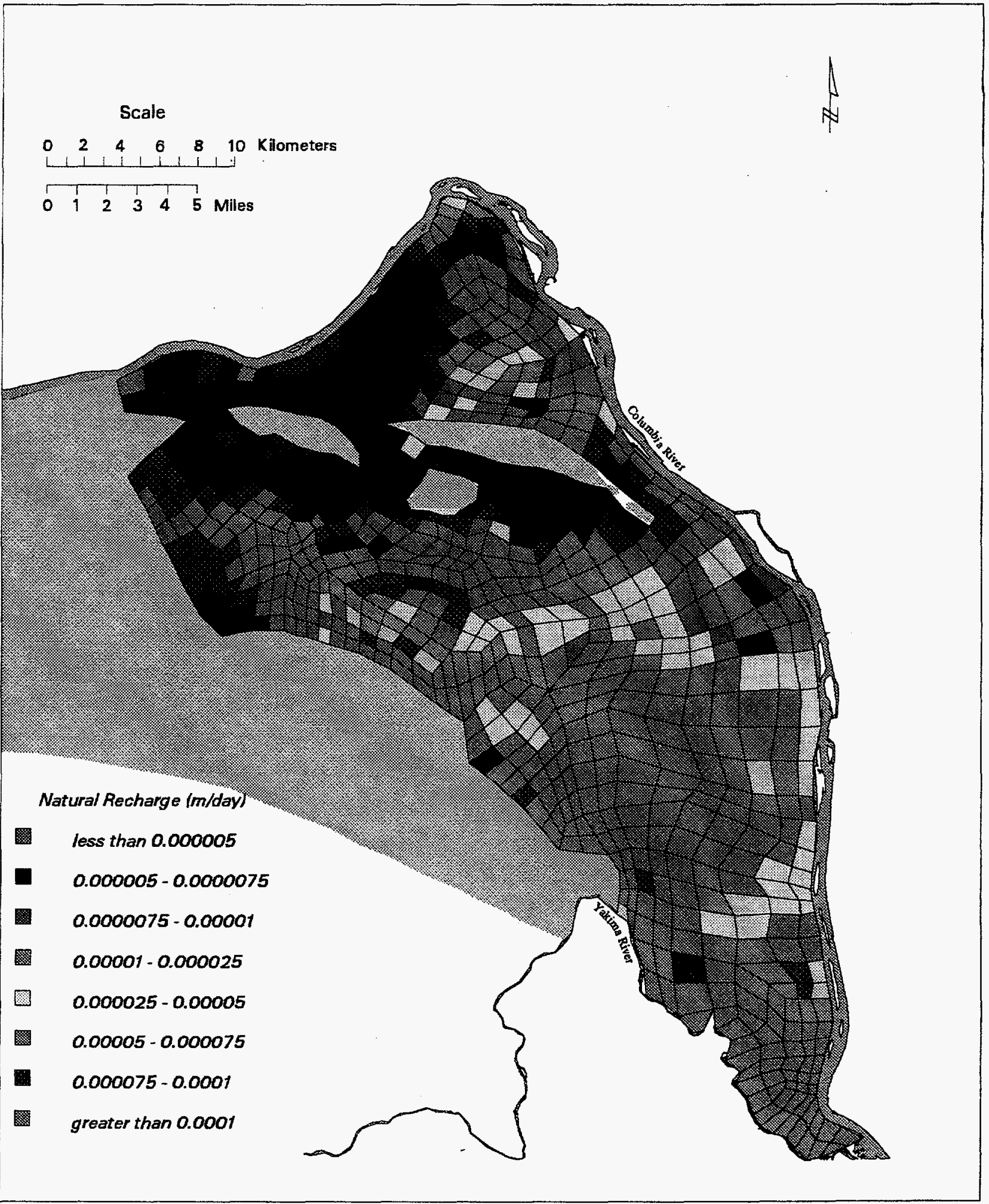

Figure 3.5. Estimated Natural Recharge Rates (m/d) Used in the Inverse Calibration 
-

-

- 


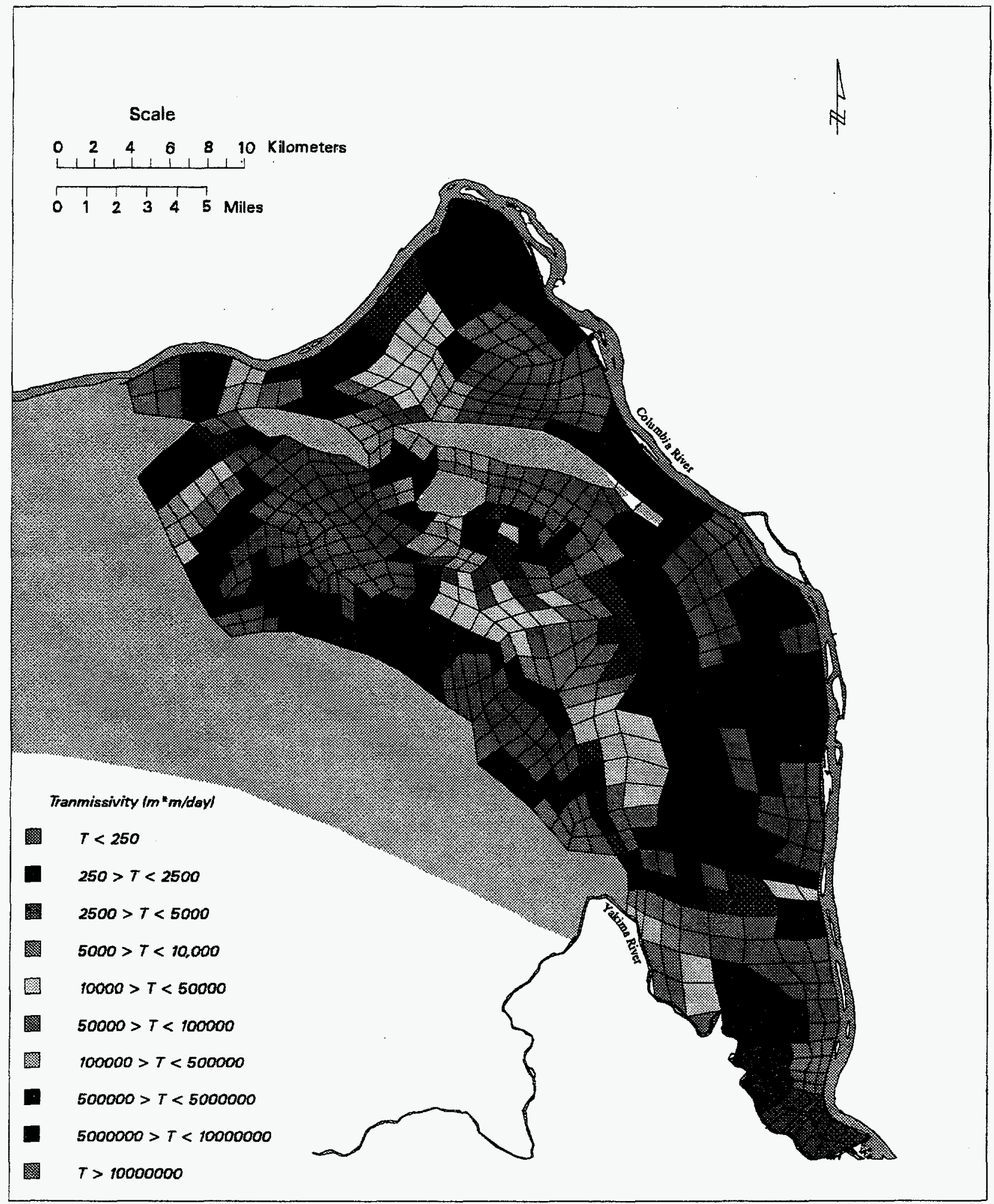

Figure 3.6. Transmissivity Distribution Obtained from the Inverse Solution 
-

-

- 


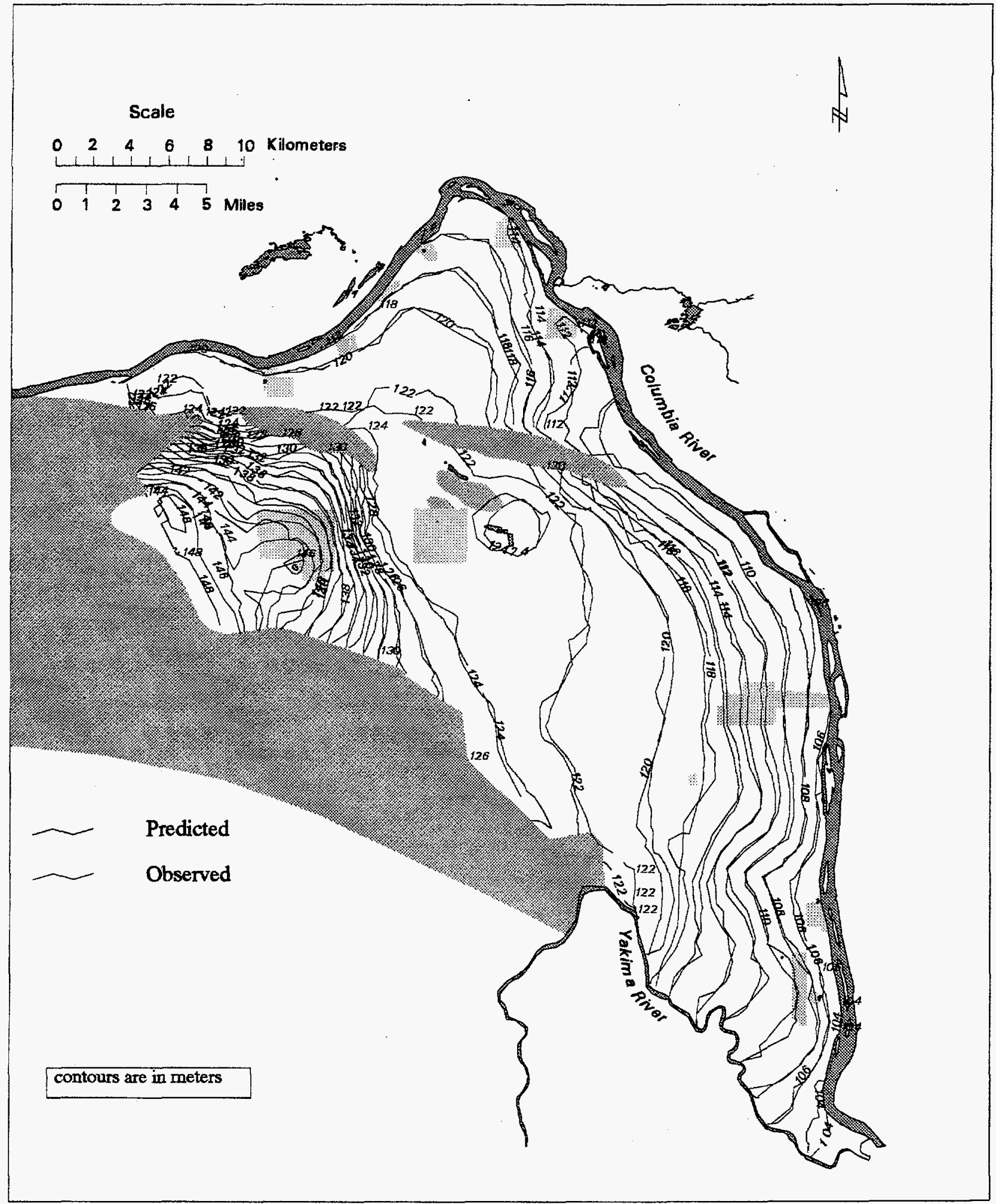

Figure 3.7. Predicted Heads Compared with Observed Using Transmissivities from the Inverse Calibration 


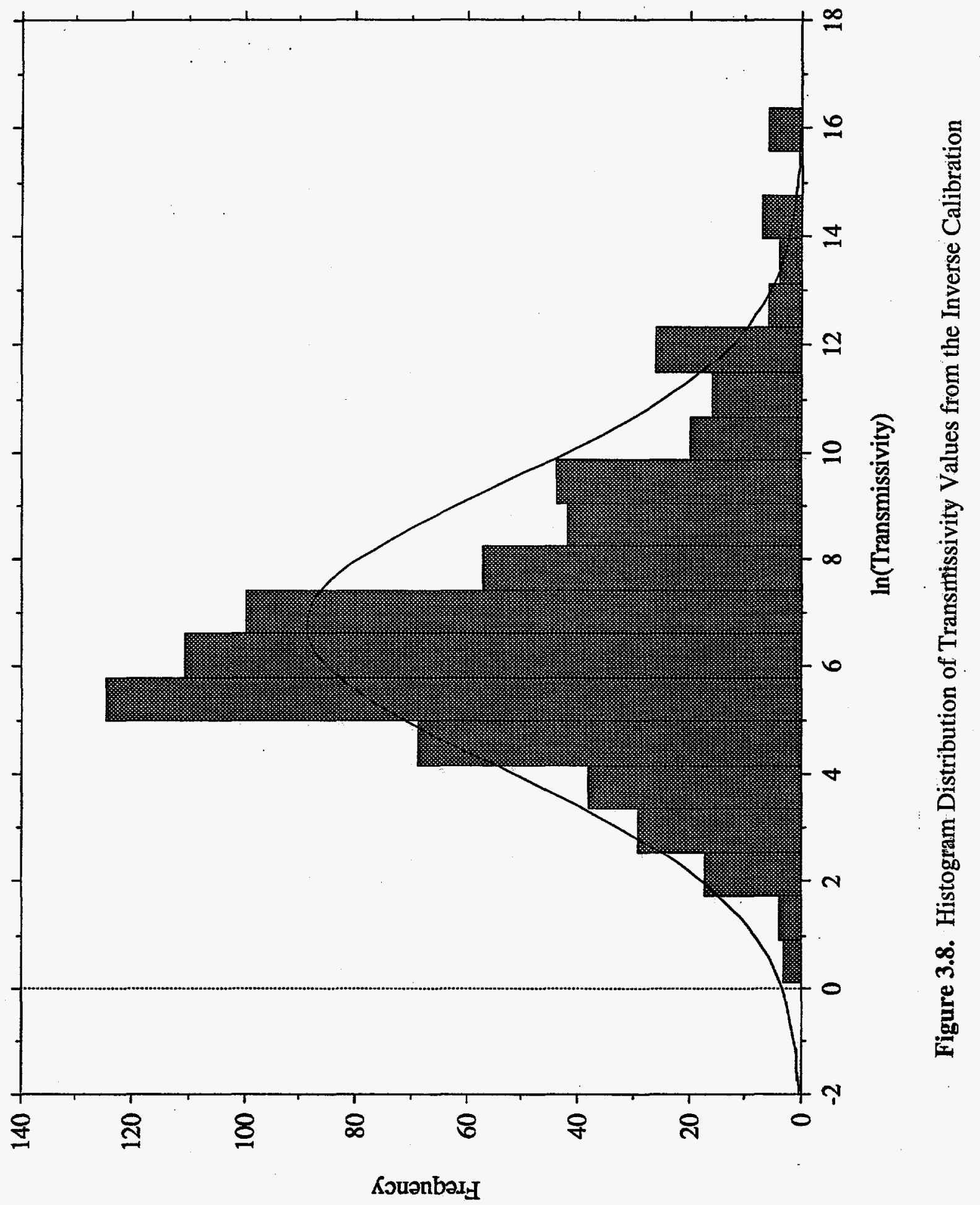




\subsection{Three-Dimensional Numerical Model}

The three-dimensional numerical model is based on information from previous models as well as new data. In the past, developing the model grid and assigning parameters to the nodes and elements has been tedious and time consuming. To make this process easier, a new approach was taken. A database of geologic and hydrologic information was developed to be independent of the model grid. This information is stored as regularly gridded data at the finest resolution permitted by the data. These data were then sampled at node and element locations to generate the numerical model. Modifications to the finite-element grid can be made and the data resampled quite easily. This allows for the conceptual model to be maintained while the numerical grid can be designed for specific problems that require special emphasis. This approach also allows for modifications and updates to the conceptual model to be easily implemented into the numerical model. In addition, the conceptual model described in Section 2.0 can be implemented in codes other than CFEST.

\subsection{Finite-Element Grid}

The CFEST finite-element grid (Figure 3.1) for the three-dimensional model was developed using ARC/INFO. The grid consists of 821 surface nodes and 721 surface elements. The placement of nodes in the grid was selected so that 1) sources would be represented as closely as possible by nodes, 2) potential contours and gradients could be resolved, and 3) geologic layer extents and other important three-dimensional hydrogeologic aspects of the problem could be represented as accurately as possible.

\subsection{Incorporation of Hydrogeologic Layers}

The numerical model consists of 10 hydrogeologic layers. Layers 1 through 9 correspond to the hydrogeologic units described in the conceptual model (Section 2.4). Layer 10 corresponds to basalt. It was assigned a uniform thickness of $10 \mathrm{~m}$ and a negligible hydraulic conductivity. Therefore, it effectively behaves as a no-flow boundary, yet allows for the existence of an element in areas where the water table will drop below the bottom of the unconfined aquifer. 
The Geological Finite Element Synthesis Tool (GEOFEST) described in Foley et al. (1995) was used to transfer the conceptual model information to the correct format for CFEST input. Bottom elevations of layers, the elevation of the water table, and grids representing hydraulic conductivity zones were inputs for GEOFEST. The GEOFEST program used this information to build the structure and assign hydraulic conductivity to the layers, creating one of the two CFEST input files.

The conceptual model was developed using the ground surface as the top of the model. The CFEST code models only the saturated portion of the unconfined aquifer, and therefore considers the top of the model to be the water table. Figures 4.1 through 4.3 show the saturated thickness of layers 1,4 , and 5, respectively. Units 2 and 3 do not occur below the December 1979 water table and, therefore, are not present in the numerical model structure. The saturated thicknesses of layers $6,7,8$, and 9 are the same as the isopachs shown in Figures 2.17, 2.15, 2.13, and 2.11 because those units are saturated everywhere. This is the hydrogeologic structure represented by the numerical model. However, by developing the conceptual model based on the ground surface, the conceptual model is not limited by the water-table elevation and therefore not limited by any particular time plane representing ground-water flow at the Hanford Site.

\subsection{Incorporation of Hydraulic Properties}

Hydraulic conductivity was assigned to the layers based on data from aquifer pumping tests, slug tests, and some lab tests as described in Section 2.5. However, because data are sparse, especially in the vertical dimension, the inverse calibration described in Section 3.0 was performed to generate a transmissivity field to aid in the three-dimensional model calibration. Some layers were assigned a constant hydraulic conductivity, while others were assigned zoned hydraulic conductivities. The goal was to preserve the total transmissivity calculated by the inverse calibration while honoring any data available for the layers.

Layers 4,7 , and 8 were assigned constant values of hydraulic conductivity of $0.0005 \mathrm{~m} / \mathrm{d}$, $10 \mathrm{~m} / \mathrm{d}$ and $0.00001 \mathrm{~m} / \mathrm{d}$, respectively. Data for percent mud was available for Layer 6, so a hydraulic conductivity for that layer could be assigned based on this information. A value of 0.01 $\mathrm{m} / \mathrm{d}$ was assigned in regions where Unit 6 was greater than $50 \%$ mud, and a value of $0.1 \mathrm{~m} / \mathrm{d}$ was assigned in regions where Unit 6 was less than $50 \%$ mud. Figure 4.4 shows the hydraulic 
conductivity zonation of Unit 6 based on percent mud. Layers 5 and 9 were at first assigned a constant value for hydraulic conductivity. However, when the total transmissivity for each element was calculated and compared to the results of the inverse calibration, it was found that in some places the transmissivity for one layer alone exceeded the total transmissivity calculated by the inverse solution. These areas were identified and established as zones with lower hydraulic conductivity than the rest of the unit.

The water table is found in either Unit 1 or Unit 5 over much of the Hanford Site (Figure 2.30). To preserve the transmissivity distribution generated by the inverse solution, a program was written to calculate the total transmissivity of the layers below the top layer, subtract this value from the total transmissivity calculated by the inverse solution, and calculate the hydraulic conductivity of the top layer by dividing the remaining transmissivity by the thickness of the top layer. This resulted in a unique value of hydraulic conductivity for each surface element, creating 734 hydraulic conductivity zones in the input file ( 721 surface elements plus 13 zones representing the underlying layers). This many zones results in computational inefficiency, so a histogram of the surface element hydraulic conductivities was created to find their natural zonation. The values were placed into 83 zones and assigned the average value for that bin based on the histogram. Figures 4.5 and 4.6 show the assigned hydraulic conductivity values based on this procedure for Layers 1 and 5 respectively.

\subsection{Incorporation of Boundary Conditions}

Boundary conditions for the surface layer of the three-dimensional model are the same as those used in the inverse calibration. Prescribed head conditions were assumed along the Columbia River and Yakima River boundaries. The PNL-CHARIMA river simulation model (Walters et al. 1994) was run to generate water surface elevations for the Columbia River. The results of this model provided river mile and river elevation based on the mean flow for 1979 at Priest Rapids Dam. This information is stored in ARC/INFO as a line with an attribute (river elevation) associated with its distance (river mile). River mile can be easily computed for each node, and then elevation can be calculated using linear interpolation. River nodes for layers below the surface were assumed to be a no-flow boundary. Prescribed head of $147 \mathrm{~m}$ was specified at the surface node of the model boundary in the Cold Creek Valley. The contribution from spring discharges along the northeast side of Rattlesnake Mountain was accounted for by a specified flow rate of $1333 \mathrm{~m} 3 / \mathrm{d}$ at 
the surface nodes. No-flow conditions were assumed in areas where the aquifer is bordered by basalt outcrops and subcrops (basalt intersecting the water table) near Gable Mountain and Gable Butte.

\subsection{Sources and Sinks}

Artificial recharge sources for the steady-state simulations are the same as for the inverse calibration and are described in Section 3.3.5. Natural recharge is also the same as for the inverse calibration and is described in Section 3.3.6. Artificial sources are stored in ARC/NFO as volumes associated with the locations of effluent discharge sites. A routine was developed that finds the nearest node to each discharge site and produces a file containing the node and volumetric flux for input into CFEST. Natural recharge is stored as regularly gridded data and averaged over each element.

\subsection{Initial Conditions}

Section 3.3.1 describes the selection and preparation of the 1979 time period hydraulic head data used as initial conditions in the three-dimensional model (Figure 3.2). These data are stored in ARC/INFO as regularly gridded data and are sampled at node locations by the GEOFEST program to generate initial conditions in the CFEST input file.

\subsection{Simulation Results}

Steady-state simulations using the three-dimensional model were run for the December 1979 time plane and compared to the observed water table and the results of the inverse calibration. Figure 4.7 shows the three-dimensional model results for the water table compared to the results of the inverse simulation. There is close agreement in all areas except in the area southeast of Gable Mountain. The discrepancy in this area is due partly to the fact that the three-dimensional model grid is slightly different than the grid used for the inverse calibration. During incorporation of the hydrogeologic layers into the three-dimensional numerical model, it was discovered that the 
pinching of units in that area could best be described by removing the element just east of Gable Mountain. Also, the results of the three-dimensional simulation would be expected to be exactly the same as the inverse results if the total transmissivity of each element was exactly the same.

However, because the surface element hydraulic conductivities were grouped into zones, slight differences are expected. These differences are minor, however, as can be seen in Figure 4.7. Figure 4.8 shows the three-dimensional model results compared to the observed water table. 


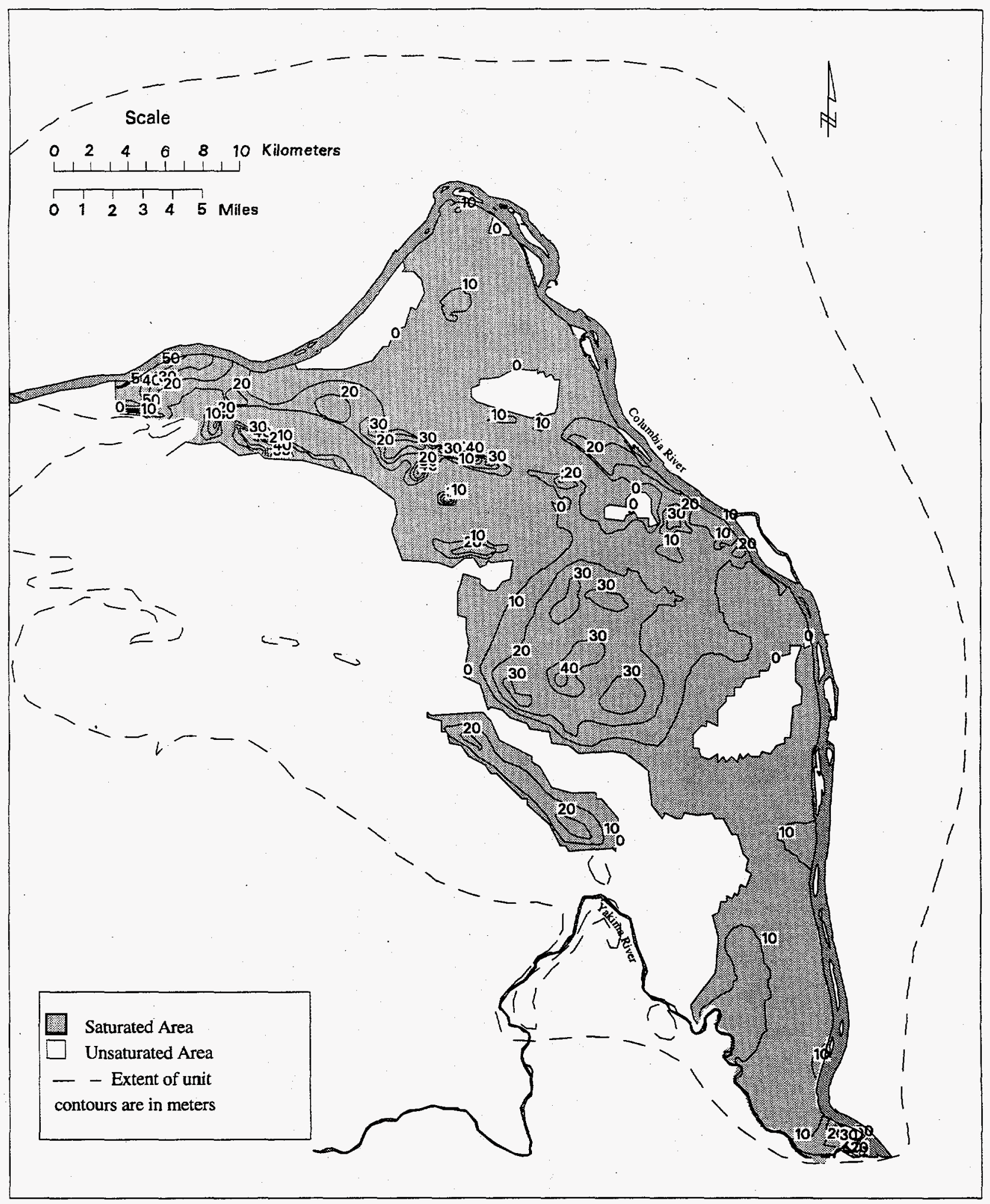

Figure 4.1. Saturated Thickness of Layer 1 


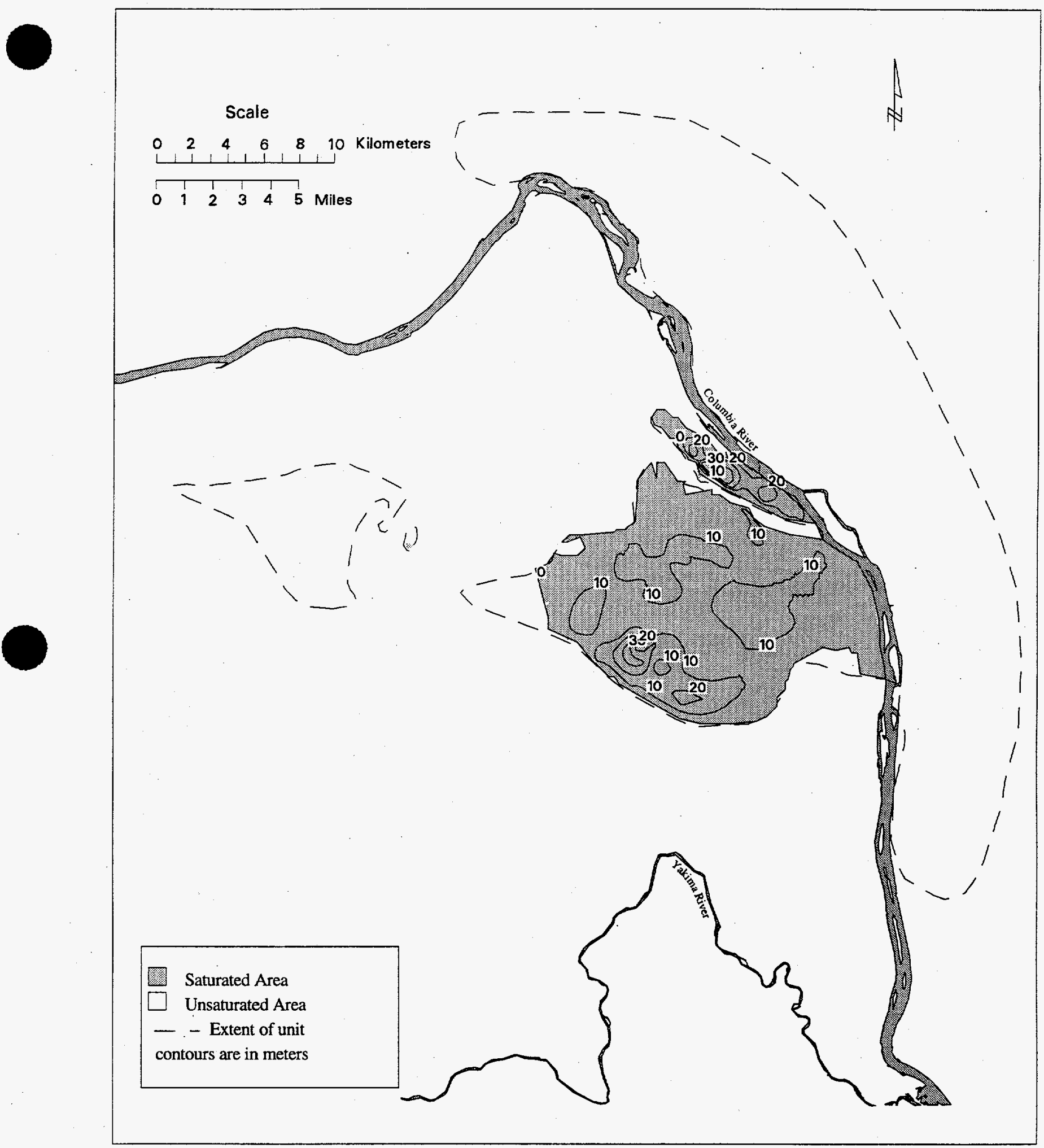

Figure 4.2. Saturated Thickness of Layer 4 


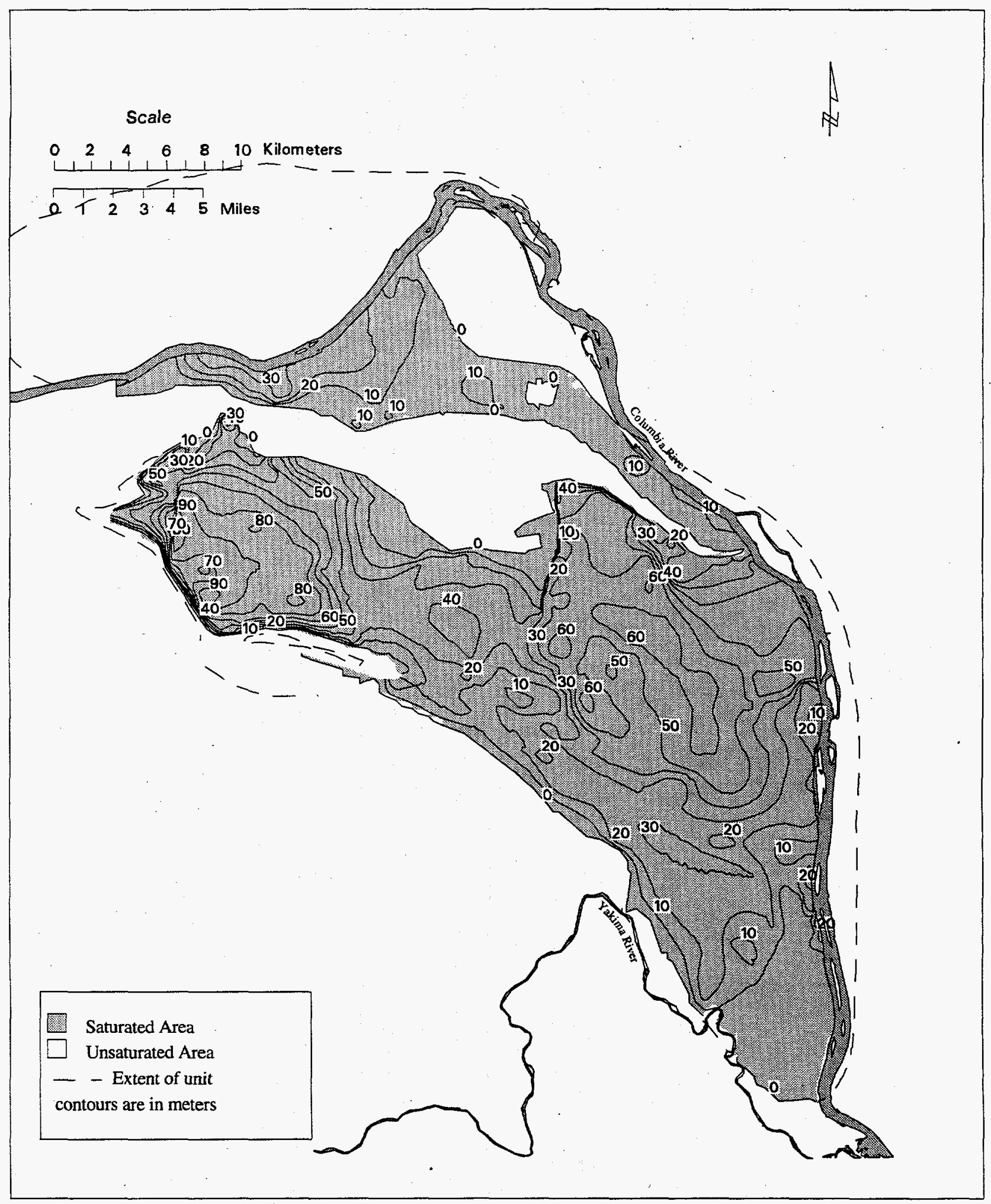

Figure 4.3. Saturated Thickness of Layer 5 


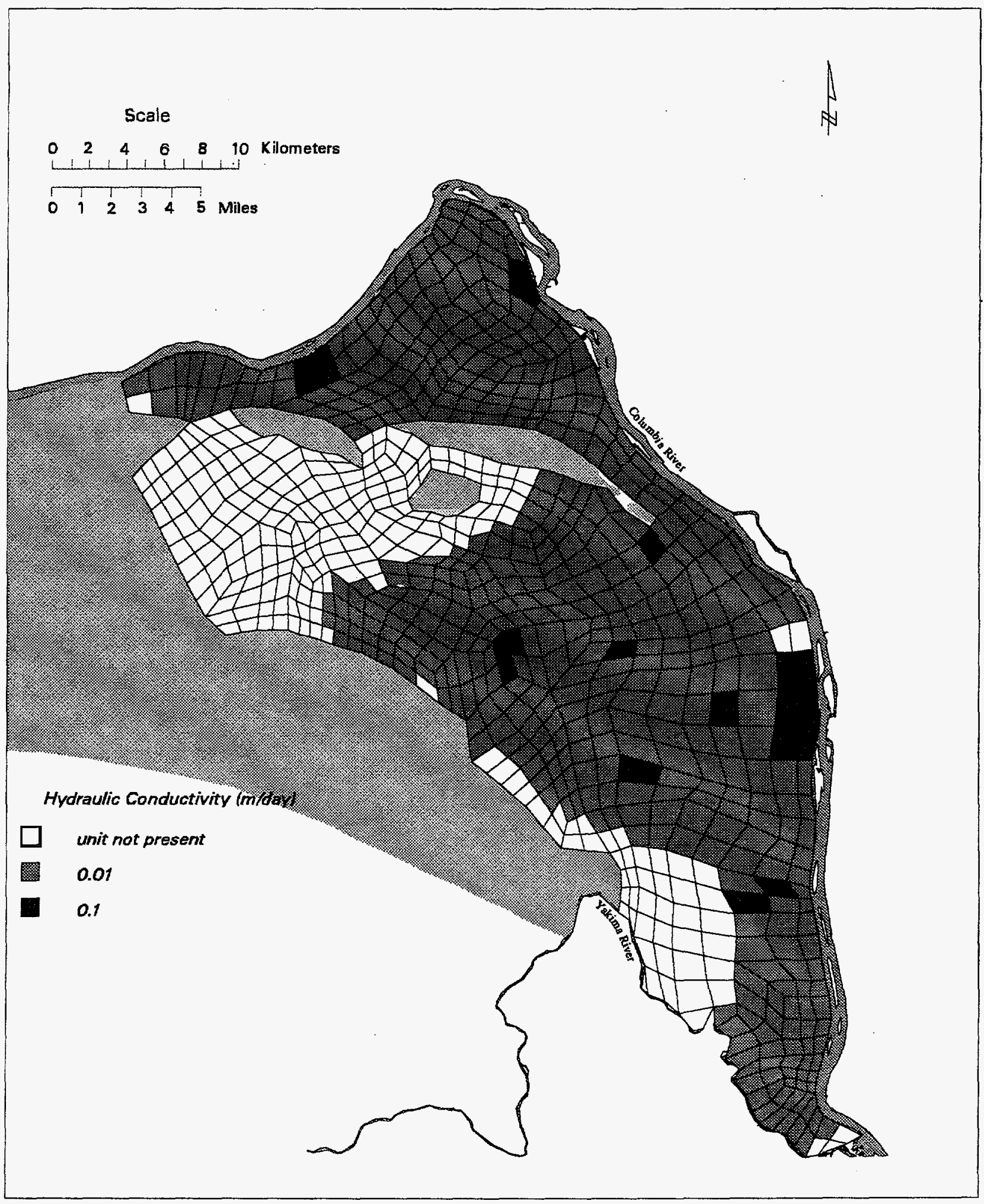

Figure 4.4. Hydraulic Conductivity Zones for Layer 6 
-

-

- 


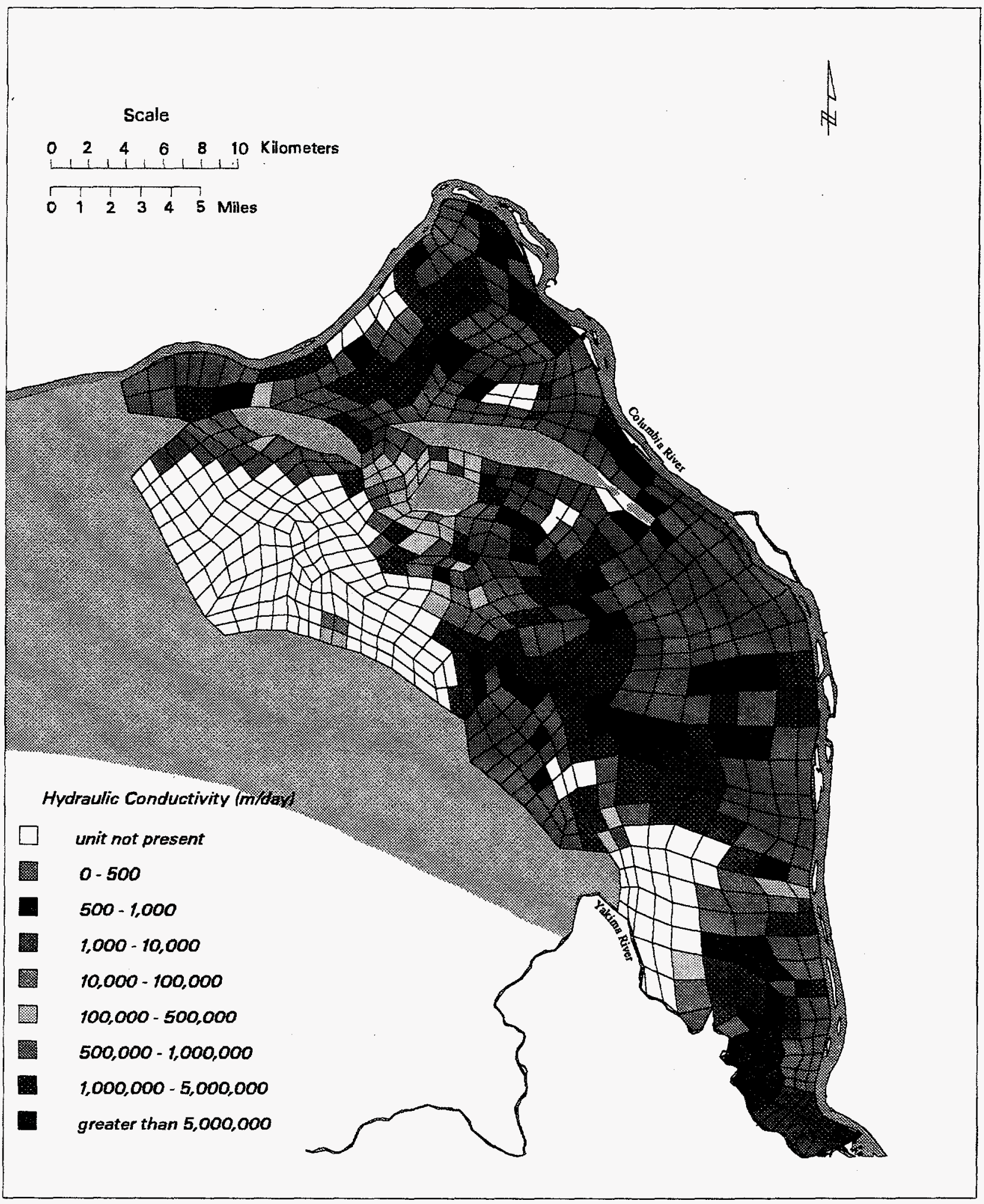

Figure 4.5. Hydraulic Conductivity Zones for Layer 1 
-

-

- 


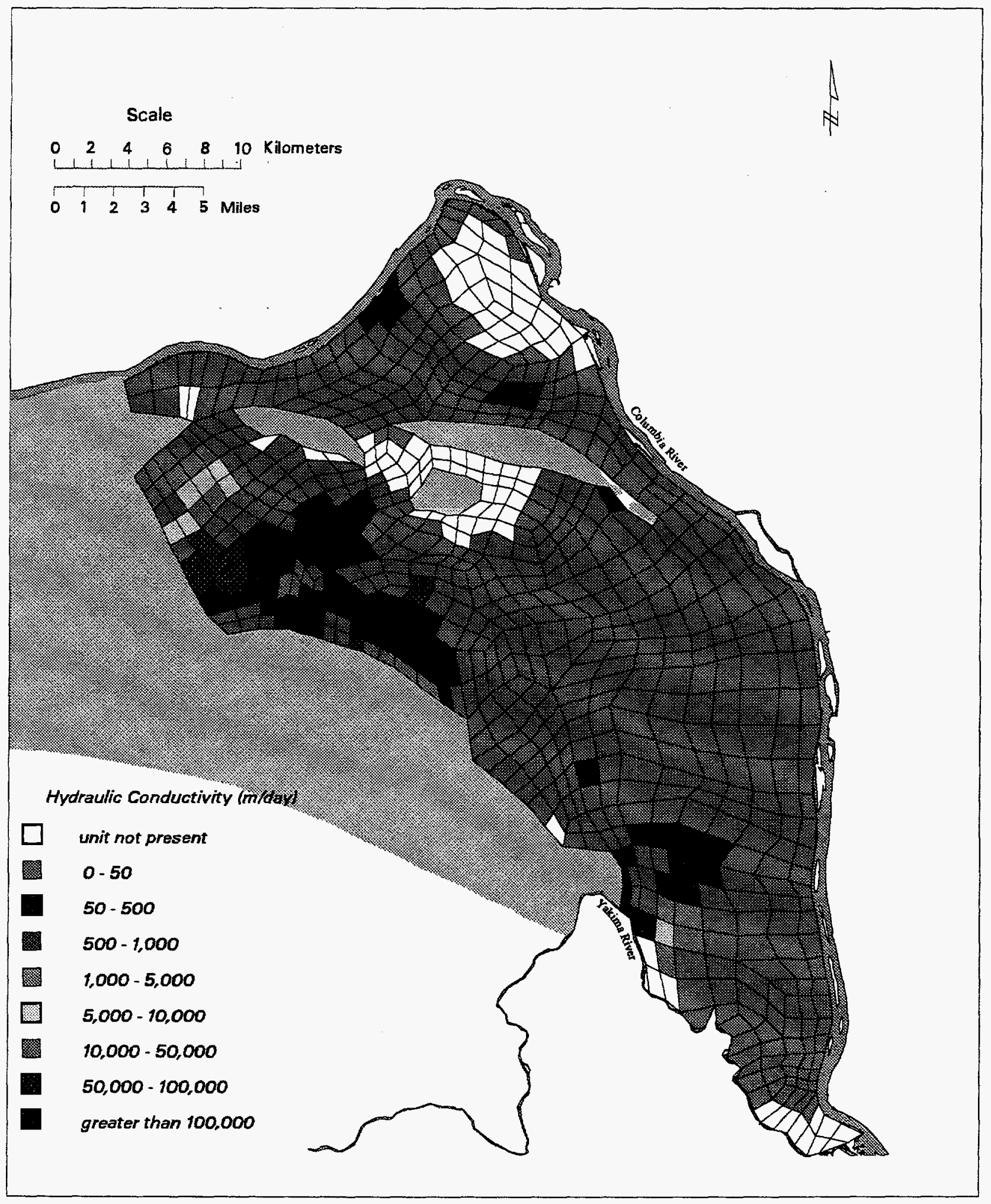

Figure 4.6. Hydraulic Conductivity Zones for Layer 5 
-

-

- 


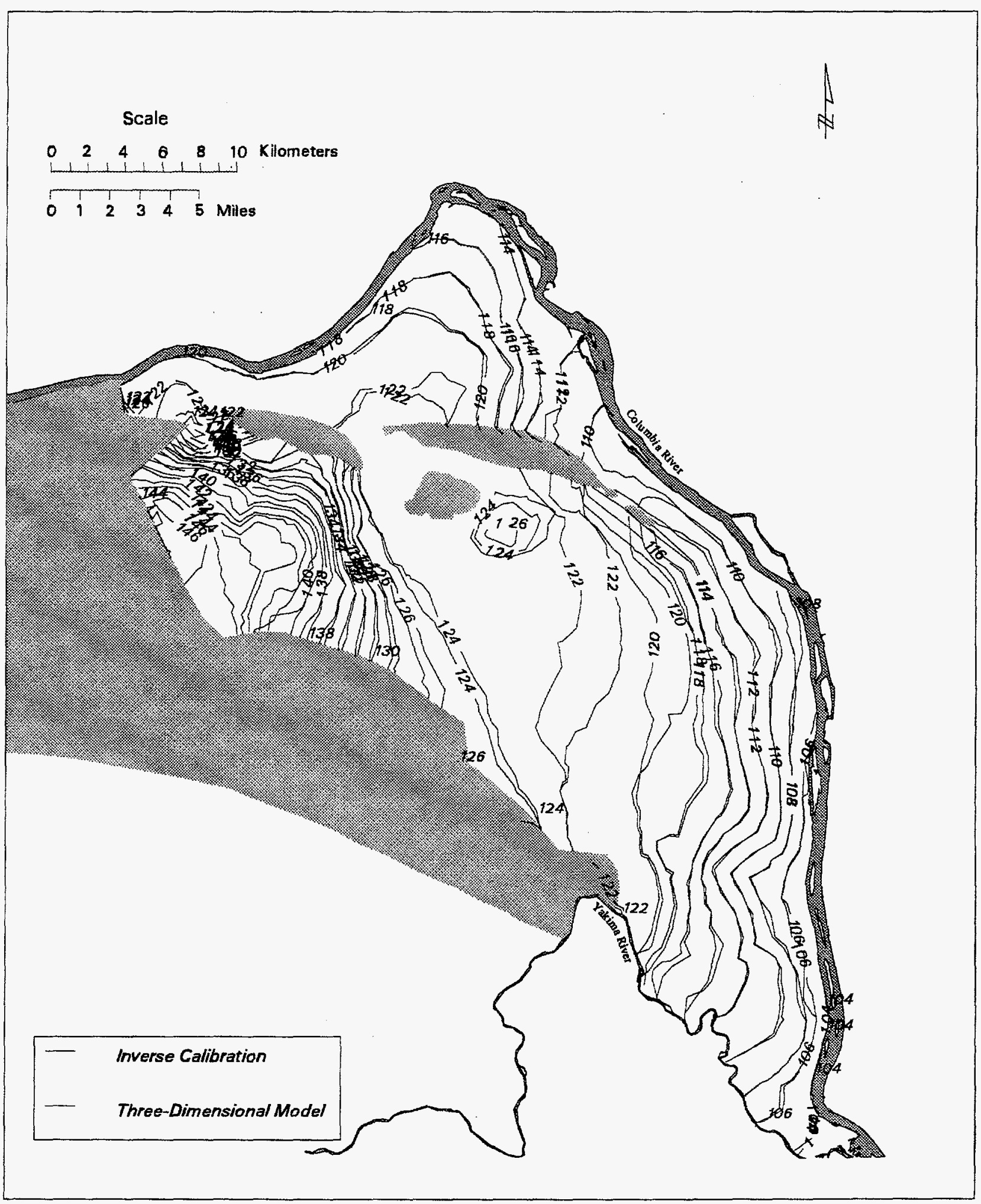

Figure 4.7. Steady-State Results of the Three-Dimensional Model Compared to Results of the Inverse Calibration 
-

-

- 


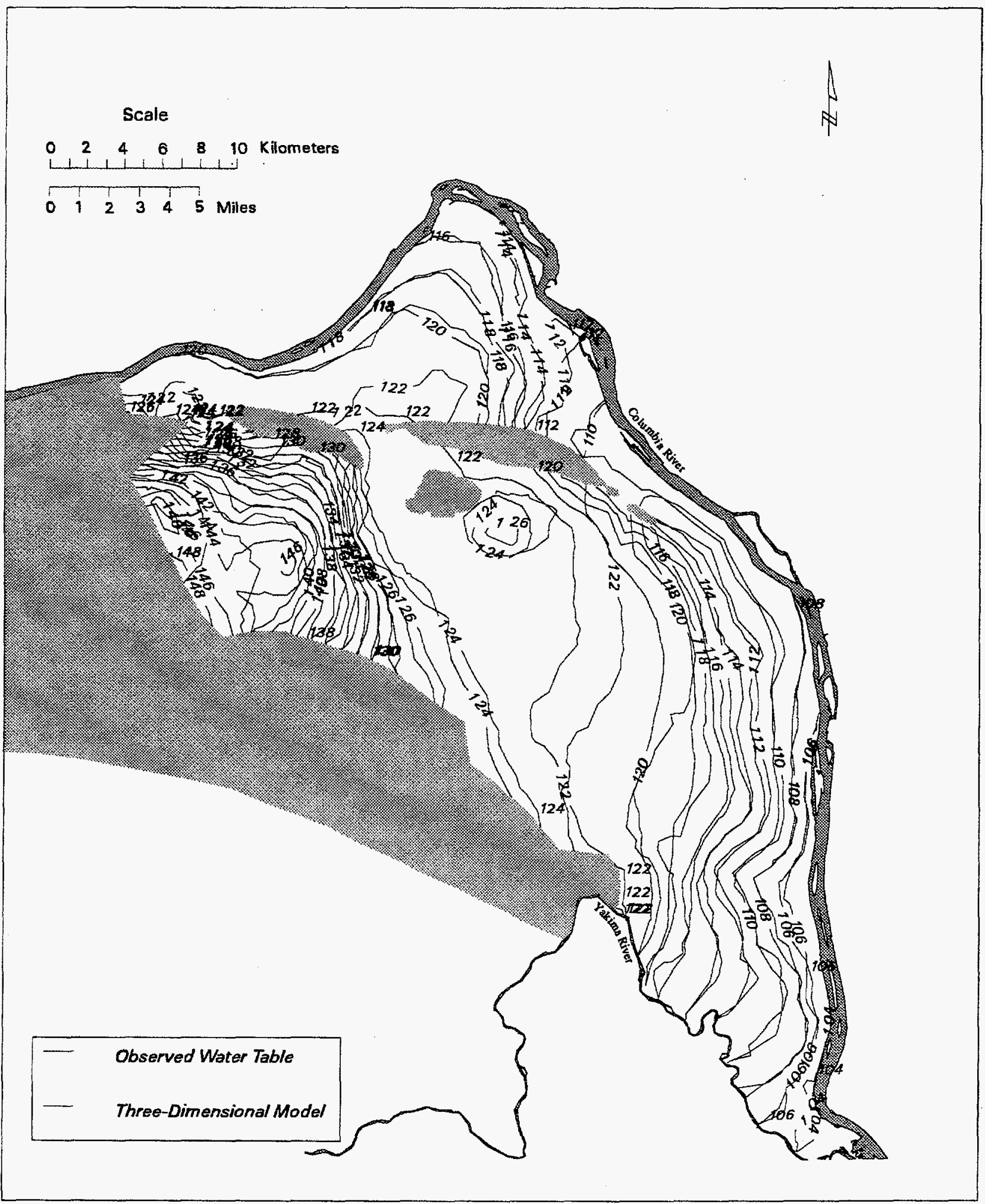

Figure 4.8. Steady-State Results of the Three-Dimensional Model Compared to the Observed Water Table 
-

- 


\subsection{Modeling Applications}

The following is a discussion of some modeling applications run at the request of DOE. The two-dimensional model described in Wurstner and Devary (1993) and Wurstner and Freshley (1994) was used for these applications.

\subsection{C-018H Facility}

An analysis of tritium migration from the $\mathrm{C}-018 \mathrm{H}$ Facility was performed. Pathlines were generated using the two-dimensional sitewide model described in Wurstner and Devary (1993) and Wurstner and Freshley (1994) with the CFEST code. Tritium transport predictions along selected pathlines were generated using the Multimedia Environmental Pollutant Assessment System (MEPAS), which is based on an analytical solution for transport (Whelan et al. 1987; Droppo et al. 1989). Transient simulations were run through the year 2040, and pathlines were generated based on these simulations. The predicted 2040 flow field is assumed to be close to steady state (Figure 5.1).

It was assumed that the facility would begin operating in September 1995, and would be shut down in December 2015. The assumptions for effluent volume were based on information provided by Westinghouse Hanford Company (WHC). An average of 26 million L/yr would be treated in campaigns lasting no more than $60 \mathrm{~d} / \mathrm{yr}$ between 1995 and 2004 . A volume of 442

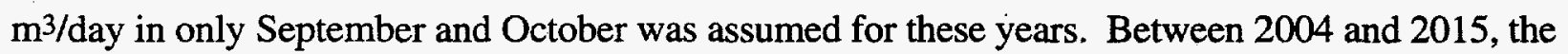
effluent volume will likely be closer to 216 million $\mathrm{L}$ of treated effluent per year, which is the high end of the range. A volume of $591 \mathrm{~m}^{3} / \mathrm{d}$ for an entire year was assumed for this time period.

Effluent was also added to the system at the W-049H site (east of 200-East Area) for the same operational period as for $\mathrm{C}-018 \mathrm{H}$. The volume for $\mathrm{W}-049 \mathrm{H}$ was based on projections that were received for a previous effort (Wurstner and Freshley 1994).

Pathlines were generated in a transient mode for the time period between June 1995 and December 2040 (Figure 5.2). Steady state was assumed for the pathlines after December 2040. Tritium concentrations were generated using MEPAS along three selected pathlines based on the assumption that the maximum concentration of tritium $(24,000,000 \mathrm{pCi} / \mathrm{L})$ was added to the system 
for the period 1995 to 2015 . Figure 5.3 shows the tritium concentrations along a selected pathline for four time periods.

Two additional scenarios were simulated with the MEPAS code to address whether tritium would be detected in well 699-51-75Q in 5 years. Scenario 1 assumed that the average source concentration $(5,600,000 \mathrm{pCi} / \mathrm{L})$ was added for $2 \mathrm{mo} / \mathrm{yr}$, for 5 years. Scenario 2 assumed that the maximum source concentration $(24,000,000 \mathrm{pCi} / \mathrm{L})$ was added for $2 \mathrm{mo} / \mathrm{yr}$, for 5 years. The tritium concentration at 5 years was calculated every $250 \mathrm{~m}$ on the pathline for each scenario. The porewater velocity that was used on this pathline for MEPAS was adjusted from $0.2 \mathrm{~m} / \mathrm{d}$ to $0.06 \mathrm{~m} / \mathrm{d}$. The value of $0.2 \mathrm{~m} / \mathrm{d}$ represents the average pore-water velocity for the entire pathline from the source to the boundary (Columbia River); the value of $0.06 \mathrm{~m} / \mathrm{d}$ represents the average pore-water velocity for the section of the pathline from the source to well $699-51-75 \mathrm{Q}$.

Figures 5.4 and 5.5 show the results for each scenario. For both scenarios, the predicted concentration was below the $300 \mathrm{pCi} / \mathrm{L}$ detection limit at a location $500 \mathrm{~m}$ from the source (the approximate distance to well 699-51-75Q). These predictions are based on assumptions that are conservative in nature. Therefore, based on these results, it is unlikely that tritium will be detected in well 699-51-75Q in 5 years.

\subsection{Evaluation of WNP-2}

An evaluation of the impacts to ground water from liquid discharges at the Washington Public Power Supply System's Nuclear Plant No. 2 (WNP-2) was performed in support of DOE's evaluation of the WNP-2 permit application.

A ground-water flow model of the Hanford Site unconfined aquifer was used to evaluate the impacts of discharges to the ground at WNP-2. A volumetric flux of $265 \mathrm{~m} 3 / \mathrm{d}$ was input to a single node representing the sanitary sewer and outfalls 002 and 003 . The model used by Wurstner and Freshley (1994) to evaluate the impacts of future water level decline on monitoring wells at Hanford was used, with discharges at WNP-2 included. Simulations were performed with and without the discharge to WNP-2, as outlined in the permit application. These simulations were continued to year 2040 . 
Simulation results showed only minor changes in water levels (Figures 5.6 and 5.7).

Results showed less than $0.5 \mathrm{~m}$ change at the source node and less at surrounding nodes, indicating that the planned discharge will have only a minor impact on the ground water. This result can be explained because the total discharge to ground at WNP-2 is small compared with the volume of ground-water underflow, and the transmissivity beneath the WNP-2 site is high.

\subsection{Travel Time Estimates from Pit 9}

Pathlines and travel times were generated using the CFEST model described in Wurstner and Freshley (1994) from Pit 9 to the Columbia River. A transient simulation beginning in December 1993 and ending in December 2005 was run. After December 2005, the assumption is that flow remains at steady state (equal to the 2005 flow field). A porosity of 0.1 was used for the pathline generation. The northernmost pathline has a travel time of $18.46 \mathrm{yr}$ and a length (distance) of $2201 \mathrm{~m}$ associated with it (Figure 5.8). This pathline begins at a location very close to Pit 9. The middle pathline has a travel time of $16.89 \mathrm{yr}$ and a length (distance) of $2704 \mathrm{~m}$ associated with it. The southernmost pathline has a travel time of $8.763 \mathrm{yr}$ and a length (distance) of $1926 \mathrm{~m}$ associated with it. 


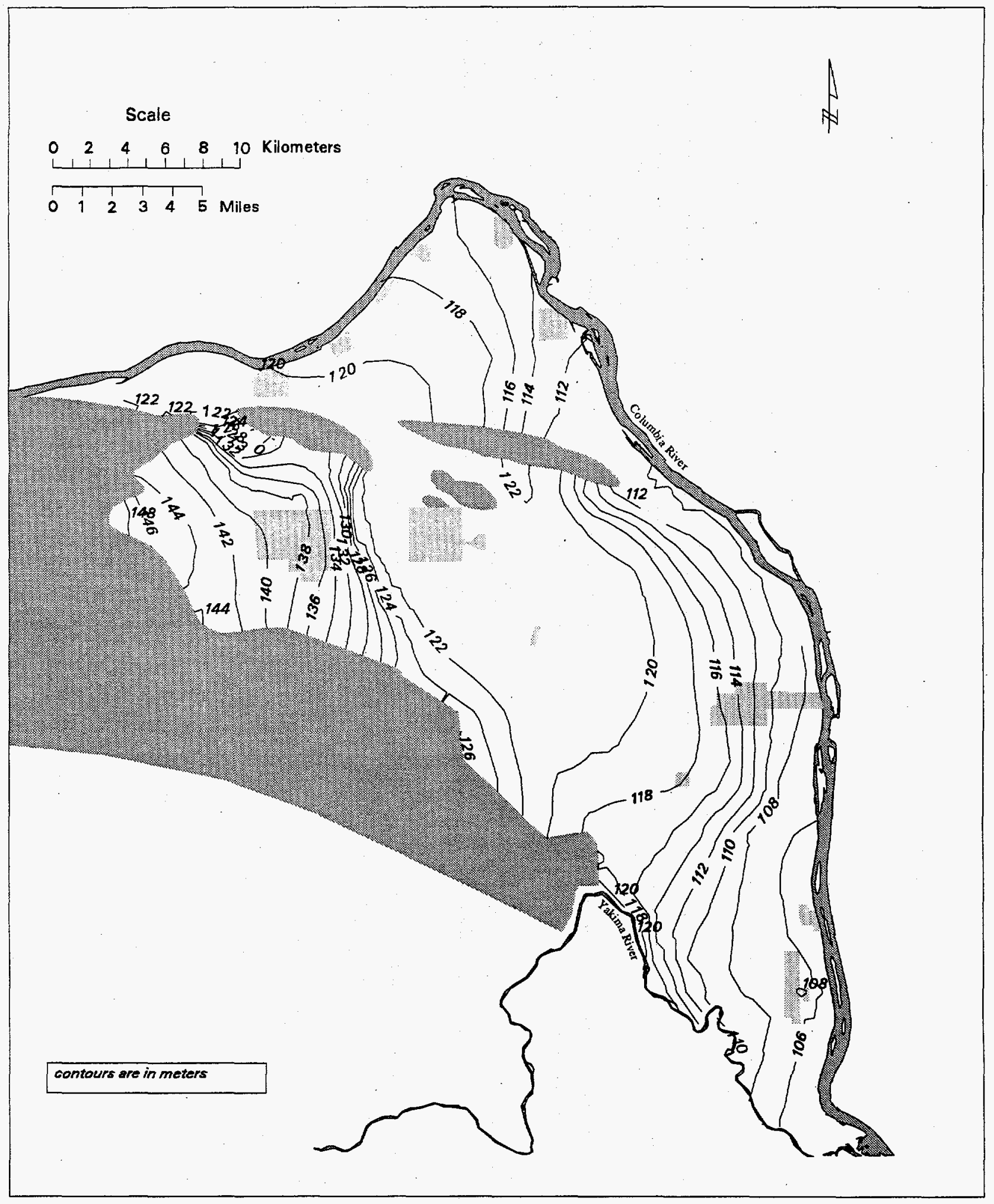

Figure 5.1. Predicted Water Table Contours for December 2040 


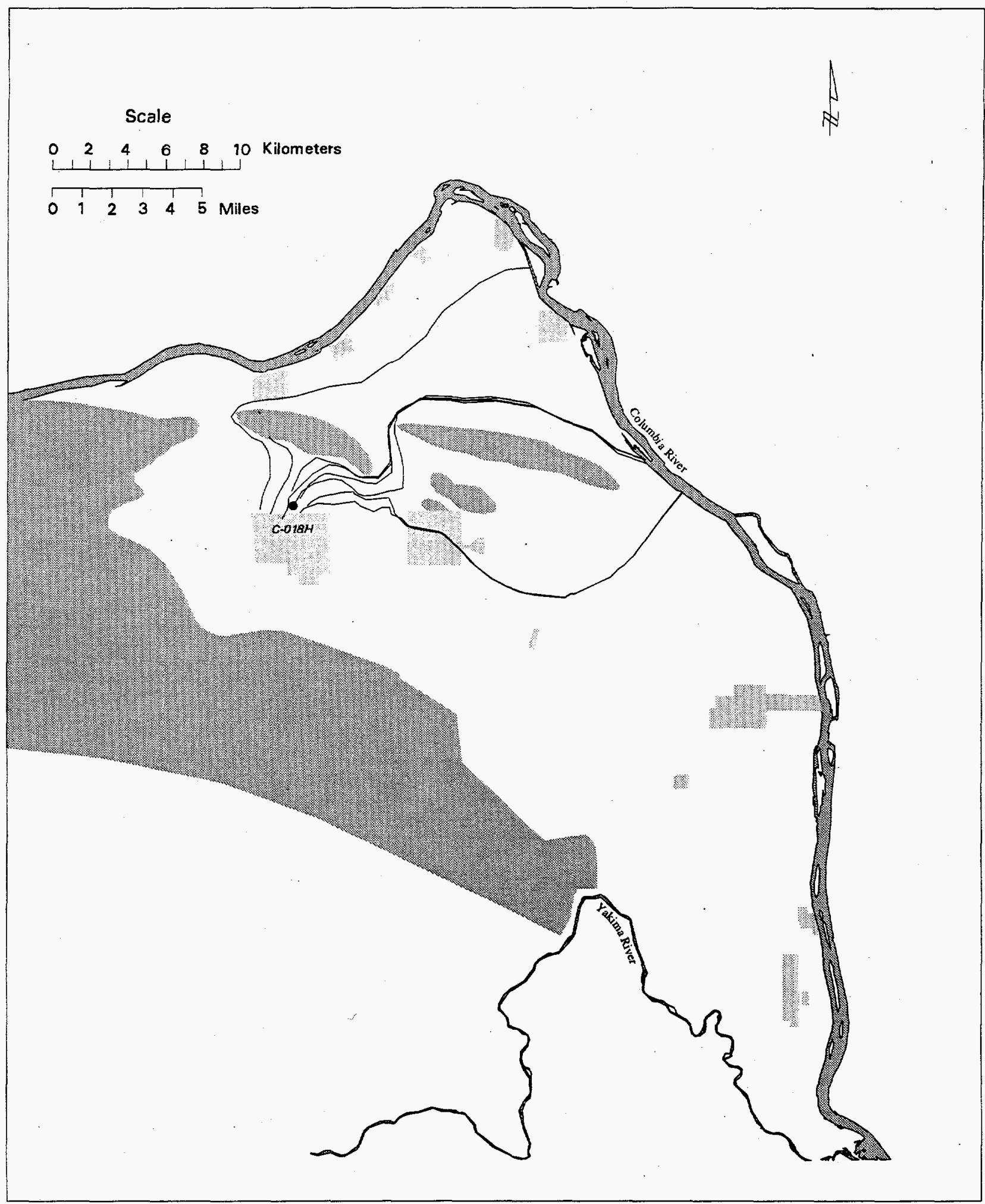

Figure 5.2. Potential Flow Paths Starting in the Vicinity of the C-018H Facility 

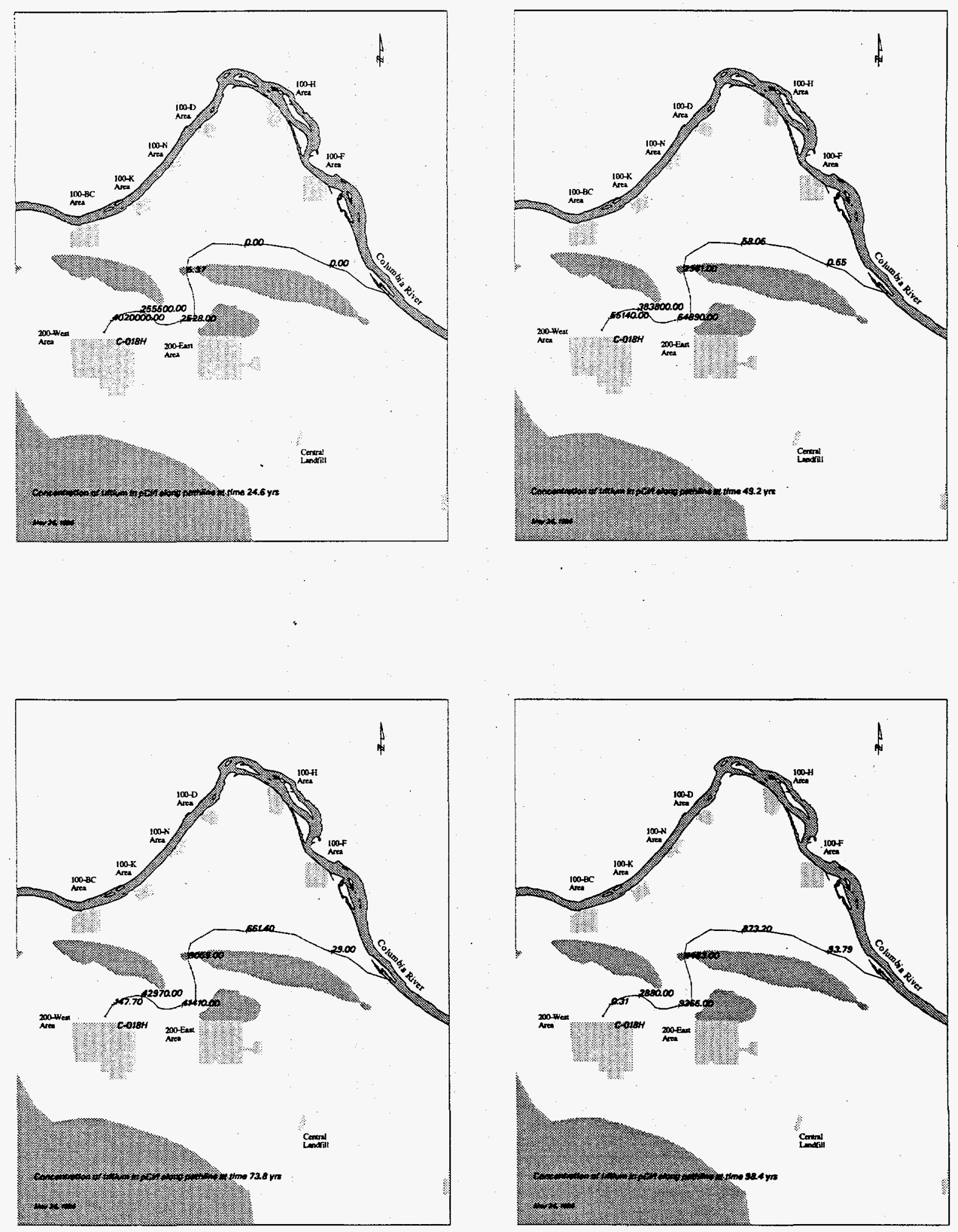

Figure 5.3. Tritium Concentrations Along Pathlines from the C-018H Facility for Four Different Time Periods 


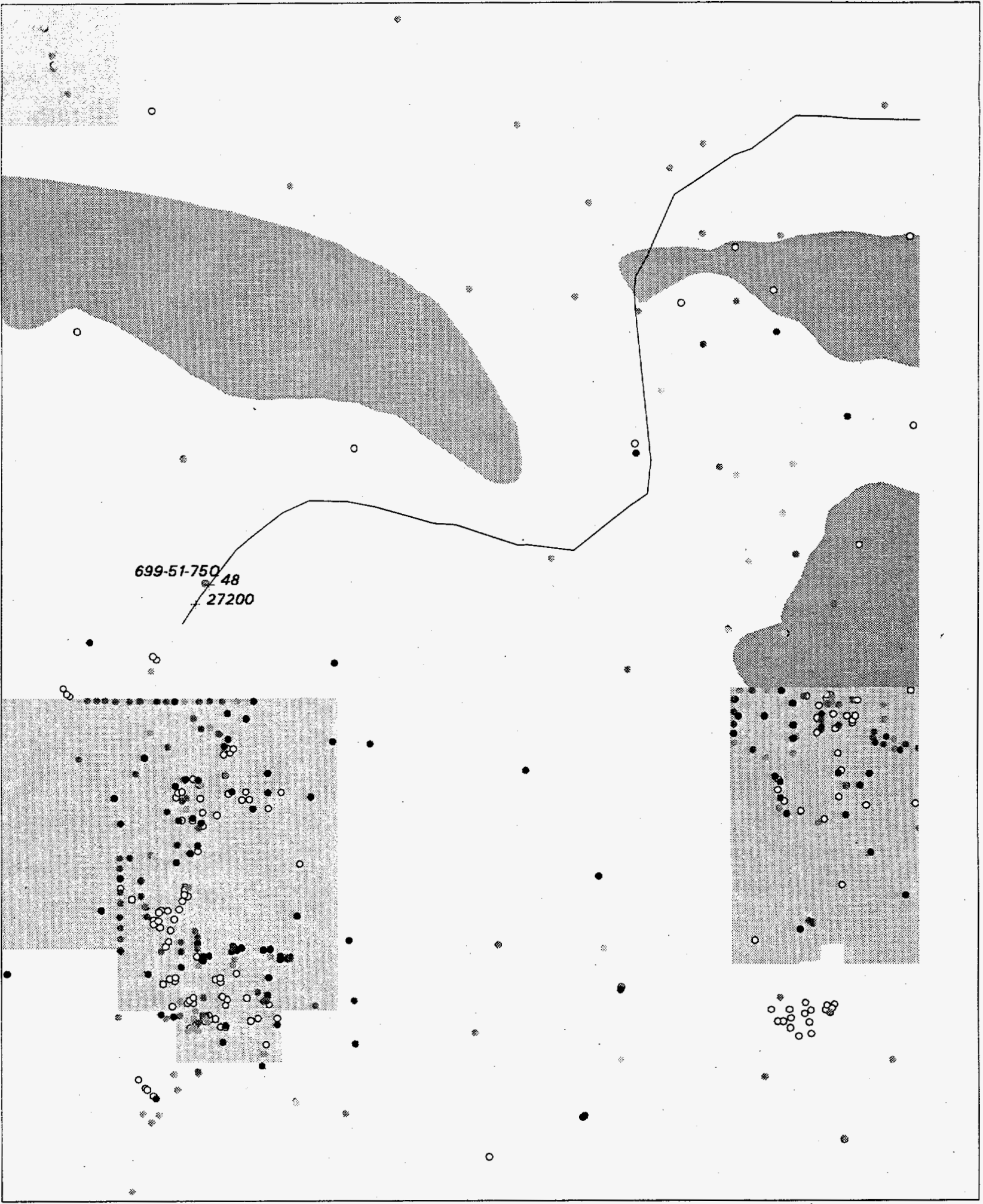

Figure 5.4. Predicted Concentration of Tritium After 5 years of Facility Operation Using the Average Source Concentration 


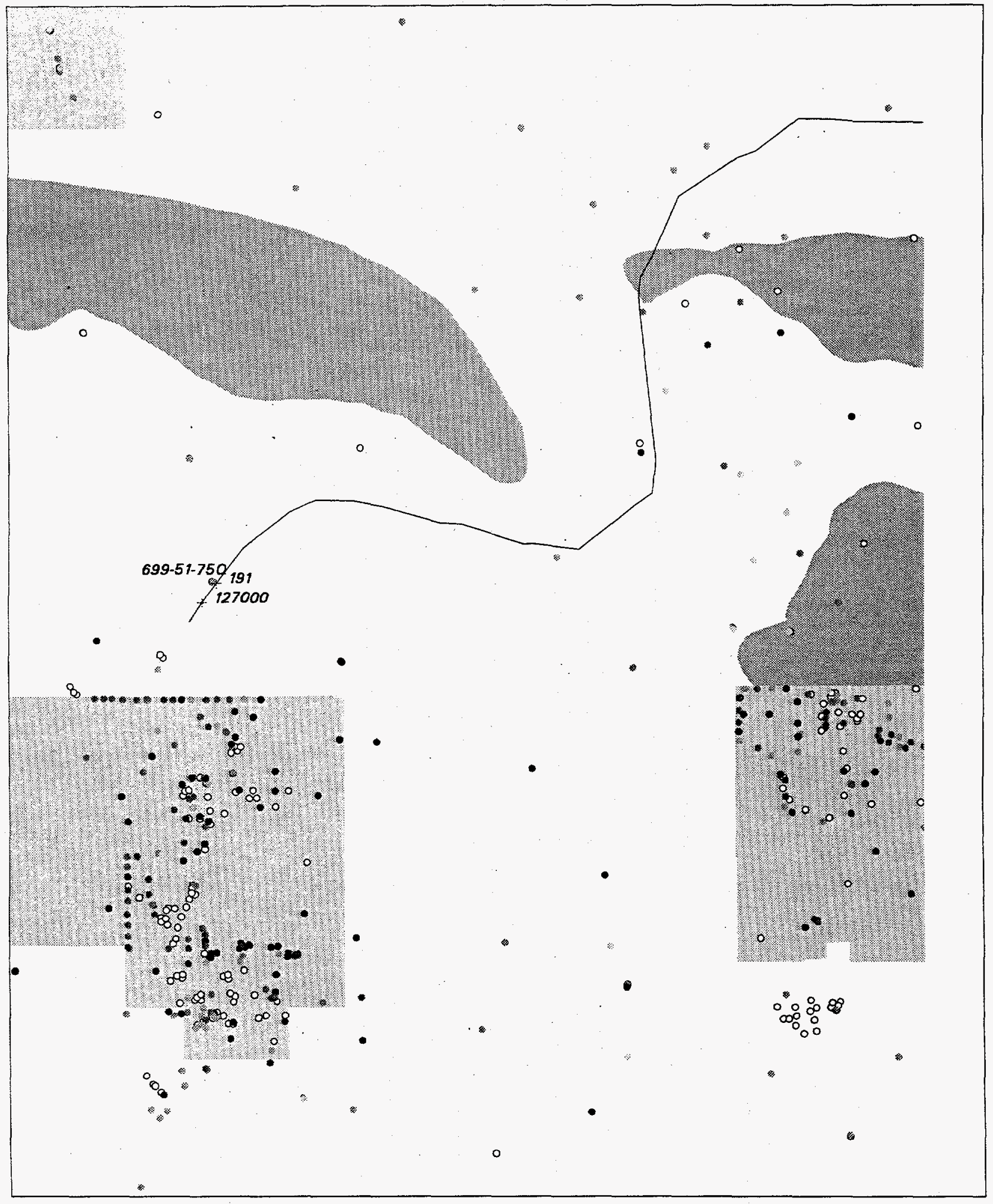

Figure 5.5. Predicted Concentration of Tritium After 5 years of Facility Operation Using the Maximum Source Concentration 

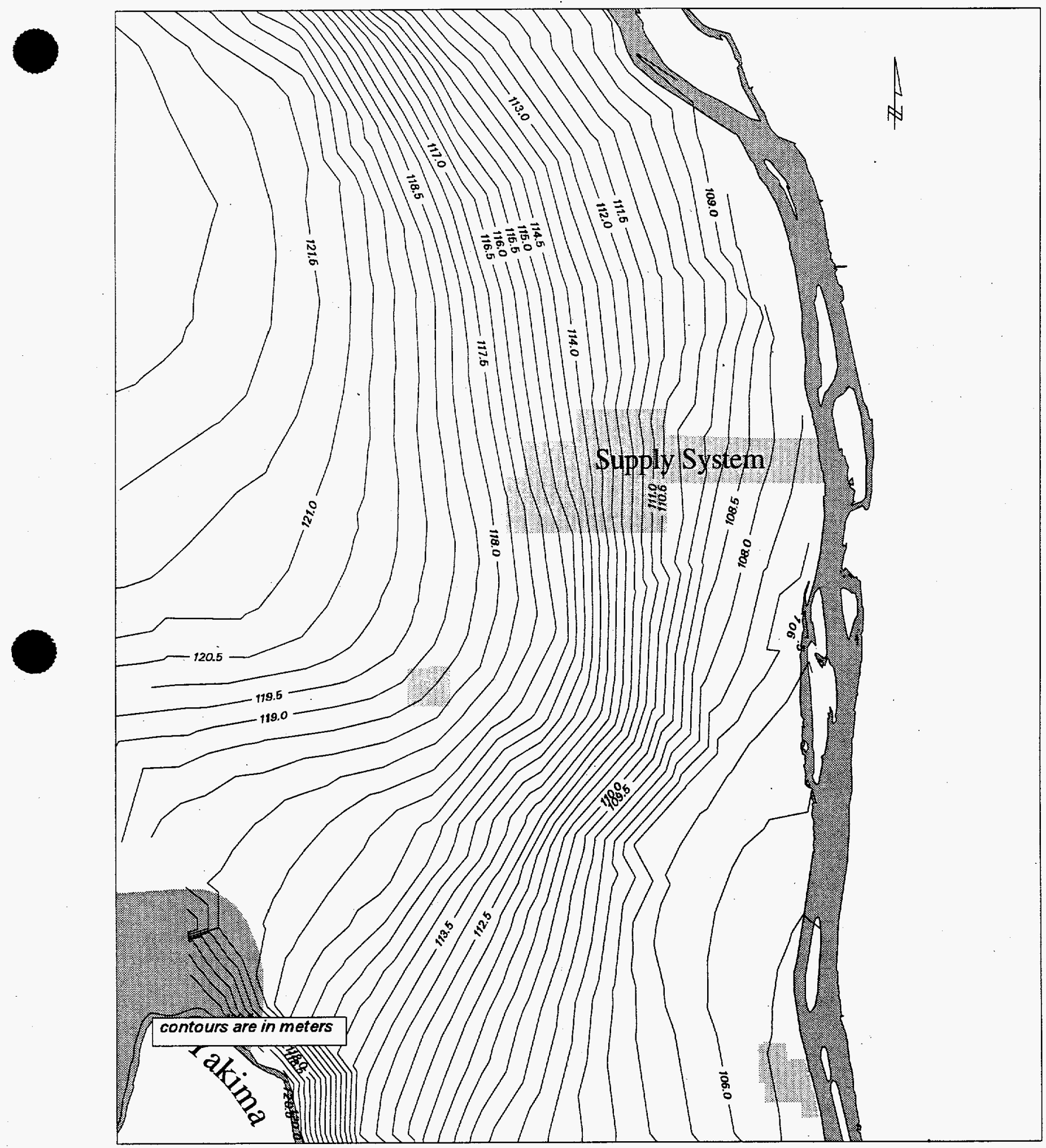

Figure 5.6. Water Table Contours for December 1992 with WNP-2 Discharges 


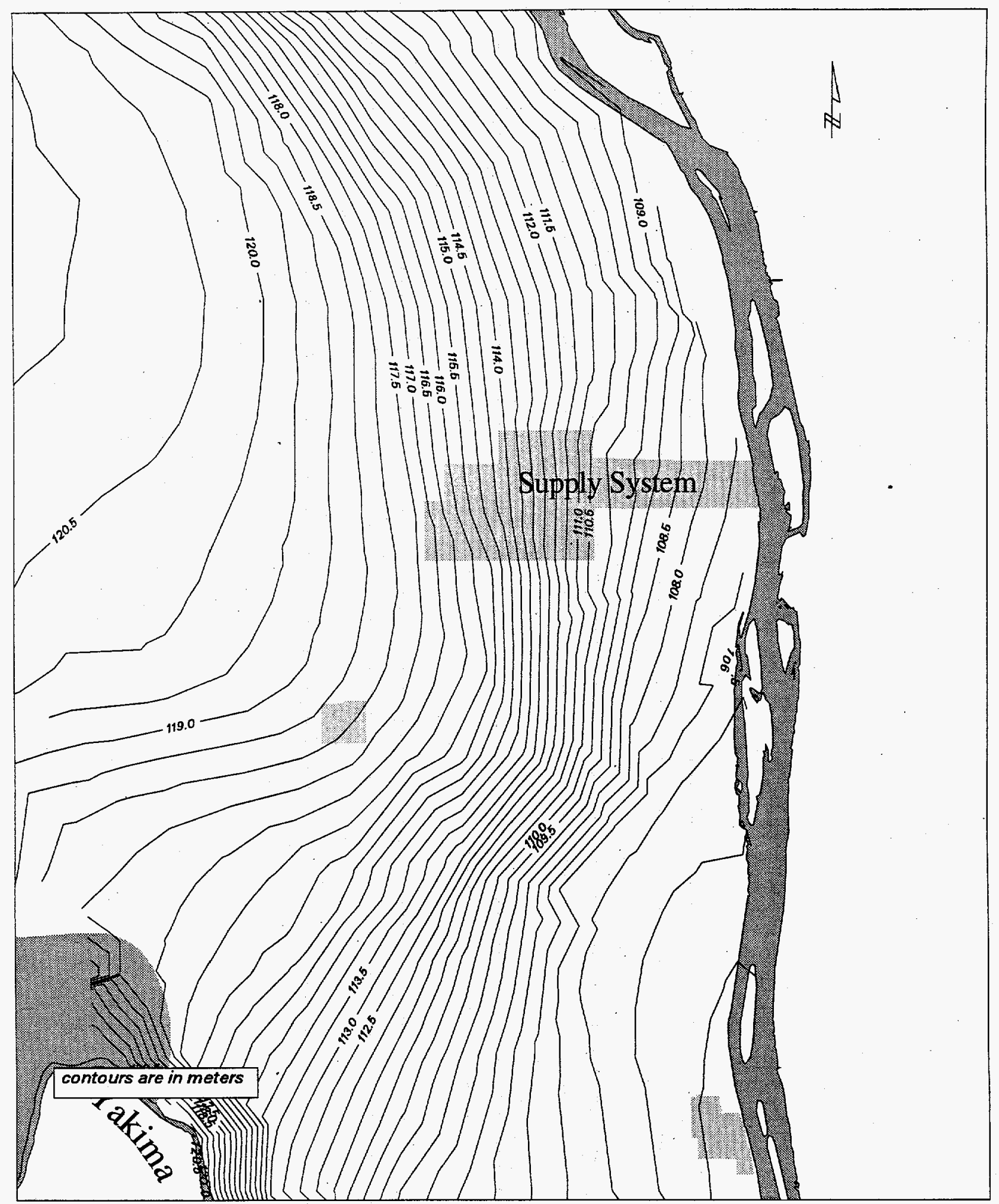

Figure 5.7. Water Table Contours for December 1992 without WNP-2 Discharges 


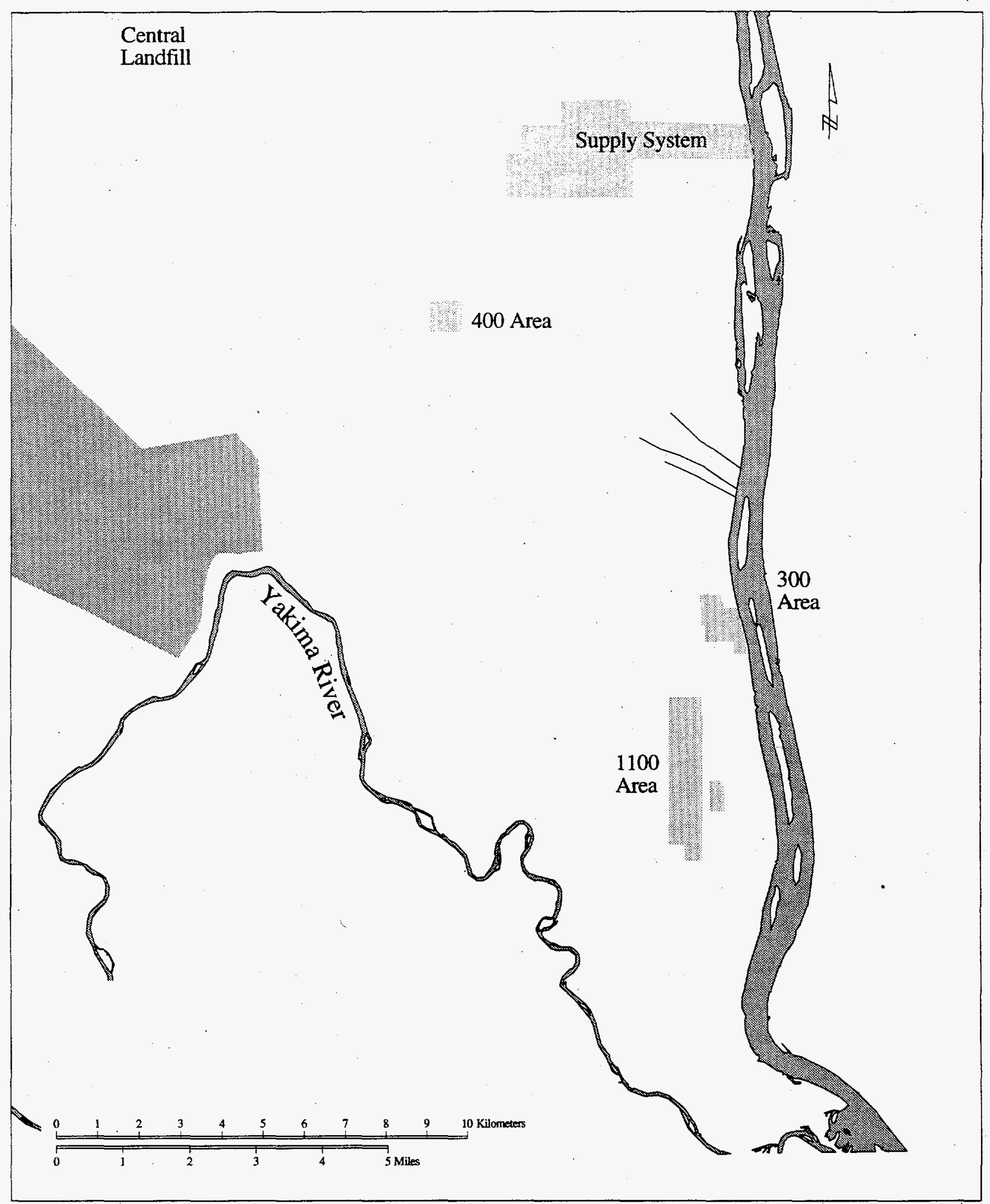

Figure 5.8. Pathlines From Pit 9 to the Columbia River 


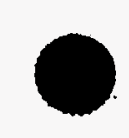

-

• 


\subsection{Discussion}

There is a degree of uncertainty inherent in all models that comes from the assumptions made when developing and applying them. Predictions with models can be made confidently for a time period comparable to the period that was matched historically, provided that future conditions do not invalidate some of the model assumptions. In making longer predictions, the cumulative errors arising from making inappropriate assumptions for the conceptual model, model structure, and parameter estimates may become significantly large (Bredehoeft and Konikow 1993).

Many assumptions that are associated with the two-dimensional Hanford Site regional ground-water model described in Wurstner and Freshley (1994) may no longer be appropriate. Since the two-dimensional model was developed, new hydrogeologic data have been collected, new interpretations have been made, and the hydrogeologic conditions and driving forces (e.g., boundary conditions) at the Hanford Site have changed. The two-dimensional model was developed based on the assumption that artificial recharge from Site operations was much greater than any natural recharge from precipitation or the basalt aquifers below the unconfined aquifer system at the Hanford Site. In the past, it was reasonable to ignore natural recharge because the flow system was dominated by effects from artificial recharge. However, artificial recharge is presently decreasing and is projected to decrease even more in the future. As the flow system approaches pre-Hanford conditions, this assumption becomes invalid, and it is crucial to include natural recharge in the model to accurately represent the water balance and the driving forces that control water movement.

Additional sources for uncertainty in the two-dimensional model that was used for the applications discussed in Section 5.0 include the use of a constant value for specific yield and a constant "average" head value assigned to the Columbia and Yakima rivers. In addition, the hydraulic conductivity distribution used in the two-dimensional model is based on an averaging of properties across Hanford and Ringold formation layers into a transmissivity value for each element. The flow system response to water being released from storage in the Hanford formation, for example, will be quite different from the response observed in the Ringold sediments because of the difference in hydraulic properties. This assumption may greatly influence the results of a transient two-dimensional simulation. In the 100 and 300 Areas, the finite elements are large, resulting in poor resolution for the solution of ground-water flow and the interpolation of simulation results from the CFEST nodes to well locations. 
Development of the three-dimensional model was initiated to address several of the assumptions described previously and to provide a better tool for the estimation of contaminant movement at the Hanford Site. The finite-element grid was refined to better represent source locations and key sampling wells. Natural recharge was included in the three-dimensional model, providing a better estimation of the water balance at the Site. This addition of recharge to the system necessitated recalibration of the model, providing a better estimate of transmissivity values. The results of applying the CFEST-INV code to the ground-water flow model of the Hanford unconfined aquifer show that the predicted water levels match observed water levels for 1979 over most of the unconfined aquifer. Some variations occur in the northern portion of the 200-West Area, but generally the predicted water levels are in excellent agreement. The predicted gradients match observed in both the steep gradient areas between the 200 Areas and near the river and the small gradient area in the central portion of the Site. Overall, application of the inverse yields a good model calibration. This recalibrated model will be used for future two-dimensional groundwater flow applications.

By considering nine layers in the model, it is possible to assign hydraulic properties to specific units instead of averaging them across layers that may have very different properties. This allows for better estimation of ground-water flow and contaminant transport. As refinement of the three-dimensional model continues, it may be possible to consider the Columbia River Boundary as a time-changing prescribed head boundary, thus incorporating river stage effects on the groundwater system. The assumption of a constant value for specific yield will still be a limitation in the three-dimensional transient model that is currently undergoing development. As described in Section 2.5.2, the data for specific yield is sparse and highly uncertain. Therefore, until better data are available, this will be a limitation of the model, although calibration of ground-water flow to measured values over a period of time can provide a good estimate of the specific yield.

The development of the three-dimensional conceptual model data was deliberately kept independent of the numerical model grid. The geologic layers were gridded using EarthVision, and then converted to ARC/NNFO format to be included in the conceptual model database. Currently, the following data exist in this database: 1) geologic layer data, 2) Columbia River stage data (by river mile), 3) natural recharge data, 4) effluent discharge data, 5) measured water table data for 1979 (initial conditions), and 6) transmissivity field calculated by the inverse calibration. By storing this information as regularly gridded data within the ARC/INFO GIS system, it is possible to use the conceptual model data at different scales (e.g., in submodels) or with different ground-water codes. 
This allows for use of the code that is most appropriate for simulating the problem being considered. Currently, links have been created between ARC/INFO and the CFEST code, but creating links to other ground-water flow and transport codes is recommended so that a suite of codes would be available for use at the Hanford Site. In addition, ARC/INFO has analysis capabilities that can be used for addressing any number of environmental questions related to ground water and future land use at the Hanford Site. 
-

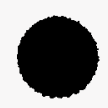




\subsection{References}

Ahlstrom, S. W., H. P. Foote, R. C. Arnett, C. P. Cole, and R. J. Serne. 1977. Multicomponent Mass Transport Model: Theory and Numerical Implementation (Discrete-Parcel-Random-Walk Version). BNWL-2127, Battelle Northwest Laboratory, Richland, Washington.

Airhart, S. P. 1990. Borehole Completion Data Package for the 216-S-10 Ditch and Pond. WHC-MR-0206, Westinghouse Hanford Company, Richland, Washington.

Ames, L. L., and R. J. Serne. 1991. Compilation of Data to Estimate Groundwater Migration Potential for Constituents in Active Liquid Discharges at the Hanford Site. PNL-7660, Pacific Northwest Laboratory, Richland, Washington.

Barnett, D. B., J. S. Schmid, S. S. Lowe, W. L. Allen, N. A. Ballantyne, C. H. Dohrer, M. J. Hartman, F. N. Hodges, D. G. Horton, V. G. Johnson, K. J. Lueck, D. J. Ortiz, A. J. Knepp, B. H. Ford, S. J. Hope, D. K. Tyler, R. D. Hildebrand, D. E. Olson, R. E. Peterson, G. L. Kasza, D. A. Myers, S. P. Luttrell, P. D. Thorne, and K. R. Moser. 1995. Hanford Site Ground Water Protection Management Plan. DOE/RL-89-12, Rev. 2, U.S. Department of Energy, Richland Operations Office, Richland, Washington.

Bierschenk, W. H. 1959. Aquifer Characteristics and Ground-Water Movement at Hanford. HW-60601, General Electric Company, Hanford Atomic Products Operation, Richland, Washington.

Bjornstad, B. N. 1984. Suprabasalt Stratigraphy Within and Adjacent to the Reference Repository Location. SD-BWI-DP-039, Rockwell Hanford Operations, Richland, Washington.

Bredehoeft, J. D., and L. F. Konikow. 1993. "Ground-Water Models: Validate or Invalidate." Editorial in Ground Water 31(2):178

Brown, R. E. 1979. A Review of Water-Well Data From the Unconfined Aquifer in the Eastern and Southern Parts of the Pasco Basin. RHO-BWI-C-56, Rockwell Hanford Operations, Richland, Washington. 
Campbell, M. D., W. J. McMahon, and K. R. Simpson. 1993. Water Level Measurements for Modeling Hydraulic Properties in the 300-FF-5 and 100 Aggregate Area Operable Units.

PNL-8580, Pacific Northwest Laboratory, Richland, Washington.

Campbell, M. D. 1994. Monitoring Groundwater and River Interaction Along the Hanford Reach of the Columbia River. PNL-9437, Pacific Northwest Laboratory, Richland, Washington.

Cearlock, D. B., K. L. Kipp, and D. R. Friedrichs. 1975. The Transmissivity Iterative Calculation Routine - Theory and Numerical Implementation. BNWL-1706, Pacific Northwest Laboratory, Richland, Washington.

Clifton, P. M., and S. P. Neuman. 1982. "Effects of Kriging and Inverse Modeling on Conditional Simulation of the Avra Valley Aquifer in Southern Arizona." Water Resources Research 18(4):1215-1234.

Cole, C. R., F. W. Bond, S. M. Brown, and G. W. Dawson. 1984. Demonstration/Application of Ground-Water Modeling Technology for Evaluation of Remedial Action Alternatives.

Contract 68-03-3116, Municipal Environmental Research Laboratory, U. S. Environmental Protection Agency, Cincinnati, Ohio.

Cole, C. R., S. B. Yabusaki, and C. T. Kincaid. 1988. CFEST-SC: Coupled Fluid, Energy, and Solute Transport Code, SuperComputer Version, Documentation and User's Manual. Battelle Pacific Northwest Laboratories, Richland, Washington.

Connelly, M. P., B. H. Ford, and J. W. Lindberg. 1992a. Hydrogeologic Model for the 200 East Groundwater Aggregate Area. WHC-SD-EN-TI-019, Westinghouse Hanford Company, Richland, Washington.

Connelly, M. P., B. H. Ford, and J. V. Borghese. 1992b. Hydrogeologic Model for the 200 West Groundwater Aggregate Area. WHC-SD-EN-TI-014, Westinghouse Hanford Company, Richland, Washington. 
Cushing, C. E. (ed.). 1995. Hanford Site National Environmental Policy Act (NEPA)

Characterization. PNL-6415, Rev. 7, Pacific Northwest Laboratory, Richland, Washington.

Davis, S. N. 1969. "Porosity and Permeability of Natural Materials." In Flow Through Porous Media, ed. R. J. M. DeWiest, pp. 54-89. Academic Press, New York.

Delaney, C. D., K. A. Lindsey, and S. P. Luttrell. 1991. Geology and Hydrology of the Hanford Site: A Standardized Text for Use in Westinghouse Hanford Company Documents and Reports. WHC-SD-ER-TI-003, Rev. 0, Westinghouse Hanford Company, Richland, Washington.

DOE (see U.S. Department of Energy)

Dove, F. H., C. R. Cole, M. G. Foley, F. W. Bond, R. E. Brown, W. J. Deutsch, M. D. Freshley, S. K. Gupta, P. J. Gutknecht, W. L. Kuhn, J. W. Lindberg, W. A. Rice, R. Schalla, J. F. Washburn, and J. T. Zellmer. 1982. AEGIS Technology Demonstration for a Nuclear Waste Repository in Basalt. PNL-3632, Pacific Northwest Laboratory, Richland, Washington.

Dresel, P. E., P. D. Thorne, S. P. Luttrell, B. M. Gillespie, W. D. Webber, J. K. Merz, J. T. Rieger, M. A. Chamness, S. K. Wurstner, and B.E. Opitz. 1995. Hanford Site Ground-Water Monitoring for 1994. PNL-10698, Pacific Northwest Laboratory, Richland, Washington.

Droppo, J. G., Jr., G. Whelan, J.W. Buck, D. L. Strenge, B. L. Hoopes, and M. B. Walter. 1989. Supplemental Mathematical Formulations: The Multimedia Environmental Pollutant Assessment System (MEPAS). PNL-7201, Pacific Northwest Laboratory, Richland, Washington.

Ebbert, J. C., S. E. Cox, B. W. Drost, and K. M. Shurr. 1993. Distribution and Sources of Nitrates, and Presence of Fluoride and Pesticides, in Parts of the Pasco Basin, Washington, 198688. Water Resources Investigations Report 93-4197, U.S. Geological Survey, Tacoma, Washington.

Eddy, P. A., D. A. Myers, and J. R. Raymond. 1978. Vertical Contamination in the Unconfined Groundwater at the Hanford Site, Washington. PNL-2724, Pacific Northwest Laboratory, Richland, Washington. 
Evans, J. C., D. I. Dennison, R. W. Bryce, P. J. Mitchell, D. R. Sherwood, K. M. Krupka, N. W. Hinman, E. A. Jacobson, and M. D. Freshley. 1988. Hanford Site Ground-Water Monitoring for July Through December 1987. PNL-6315-2, Pacific Northwest Laboratory, Richland, Washington.

Fayer, M. J., and T. B. Walters. 1995. Estimated Recharge Rates at the Hanford Site. PNL-10285, Pacific Northwest Laboratory, Richland, Washington.

Foley, M. G., D. J. Bradley, C. R. Cole, J. P. Hanson, K. A. Hoover, W. A. Perkins, and M. D. Williams. 1995. Hydrogeology of the West Siberian Basin and Tomsk Region. PNL10585, Pacific Northwest Laboratory, Richland, Washington.

Freeze, R. A., and J. A. Cherry. 1979. Groundwater. Prentice-Hall, Inc., Englewood Cliffs, New Jersey.

Freshley, M. D., and M. J. Graham. 1988. Estimation of Ground-Water Travel Time at the Hanford Site: Description, Past Work, and Future Needs. PNL-6328, Pacific Northwest Laboratory, Richland, Washington.

Friedrichs, D. R., C. R. Cole, and R. C. Arnett. 1977. Hanford Pathline Calculational Program Theory, Error Analysis and Applications. ARH-ST-149; Atlantic Richfield Hanford Company, Richland, Washington.

Fruland, R. M., and R. E. Lundgren, eds. 1989. RCRA Ground-Water Monitoring Projects for Hanford Facilities: Annual Progress Report for 1988. PNL-6852, Pacific Northwest Laboratory, Richland, Washington.

Gale J., R. Macleod, J. Welhan, C. R. Cole, and L. W. Vail. 1987. Hydrogeological Characterization of the Stripa Site. Technical Report 87-15, SKB, Stockholm, Sweden.

Gee, G. W., M. J. Fayer, M. L. Rockhold, and M. D. Campbell. 1992. "Variations in Recharge at the Hanford Site." Northwest Science 66:237-250. 
Gelhar, L. W., A. Mantoflou, C. Welty, and K. R. Reyfeldt. 1985. A Review of Field Scale Physical Solute Transport Processes in Saturated and Unsaturated Porous Media. RP-2485-05, Electric Power Research Institute, Palo Alto, California.

Gelhar, L. W., C. Welty, and K. R. Reyfeldt. 1992. "A Critical Review of Field-Scale Dispersion in Aquifers." Water Resources Research 28(1955-1974).

Goode, D. J., and L. F. Konikow. 1990. "Apparent Dispersion in Groundwater Flow." Water Resources Research 26(10):2339-2351.

Graham, M. J., G. V. Last, and K. R. Fecht. 1984. An Assessment of Aquifer Intercommunication in the B Pond, Gable Mountain Pond Area. RHO-RE-ST-12P, Rockwell Hanford Operations, Richland, Washington.

Gupta, S. K., C. R. Cole, C. T. Kincaid, and A. M. Monti. 1987. Coupled Fluid, Energy, and Solute Transport (CFEST) Model: Formulation and User's Manual. Report BMI/ONWI-660, Battelle Memorial Institute, Columbus, Ohio.

Hartman, M. J., and K. A. Lindsey. 1993. Hydrogeology of the 100-N Area, Hanford Site, Washington. WHC-SD-EN-EV-027, Westinghouse Hanford Company, Richland, Washington.

Jacobson, E. A. 1985. A Statistical Parameter Estimation Method Using Singular Value Decomposition With Application to Avra Valley Aquifer in Southern Arizona. Dissertation, Department of Hydrology and Water Resources, University of Arizona, Tucson, Arizona.

Jacobson, E. A., and M. D. Freshley. 1990. An Initial Inverse Calibration of the Ground-Water Flow Model for the Hanford Unconfined Aquifer. PNL-7144, Pacific Northwest Laboratory, Richland, Washington.

Jensen, E. J. 1987. An Evaluation of Aquifer Intercommunication Between the Unconfined and Rattlesnake Ridge Aquifers on the Hanford Site. PNL-6313, Pacific Northwest Laboratories, Richland, Washington. 
Johnson, V. G., D. L. Graham, and S. P. Reidel. 1993. "Methane in Columbia River Basalt Aquifers: Isotopic and Geohydrologic Evidence for a Deep Coal-Bed Gas Source in the Columbia Basin, Washington." Am. Assoc. Pet. Geol. Bulletin 77(7):1192-1207.

Kaplan, D. I. and R. J. Serne. 1995. Distribution Coefficient Values Describing Iodine, Neptunium, Selenium, Technetium, and Uranium Sorption to Hanford Sediments. PNL-10379, SUP. 1, Pacific Northwest Laboratory, Richland, Washington.

Kipp, K. L., A. E. Reisenauer, C. R. Cole, and L. A. Bryan. 1972. Variable Thickness Transient Groundwater Flow Model: Theory and Numerical Implementation. BNWL-1703, Pacific Northwest Laboratory, Richland, Washington.

Last, G. V., and V. H. Rohay. 1993. Refined Conceptual Model for the Volatile Organic Compounds - Arid Integrated Demonstration and 200 West Area Carbon Tetrachloride Expedited Response Action, PNL-8597, Pacific Northwest Laboratory, Richland, Washington.

Law, A. G. 1992. Groundwater Modeling and Plume Migration Analyses for Candidate Soil Column Disposal Sites Hanford, Washington. WHC-SD-EN-ES-022, Westinghouse Hanford Company, Richland, Washington.

Liikala, T. L., R. L. Aaberg, N. J. Aimo, D. J. Bates, T. J Gilmore, E. J. Jensen, G. V. Last, P. L. Oberlander, K. B. Olsen, K. R. Oster, L. R. Roome, J. C. Simpson, S. S. Teel, and E. J. Westergard. 1988. Geohydrologic Characterization of the Area Surrounding the 183-H Solar Evaporation Basins. PNL-6728, Pacific Northwest Laboratory, Richland, Washington.

Liikala, T. L. 1994. Hydrogeology Along the Southern Boundary of the Hanford Site Between the Yakima and Columbia Rivers, Washington. PNL-10094, Pacific Northwest Laboratory, Richland, Washington.

Lindberg, J. W. 1993a. Geology of the 100-B/C Area, Hanford Site, South-Central Washington. WHC-SD-EN-TI-133, Westinghouse Hanford Company, Richland, Washington.

Lindberg, J. W. 1993b. Geology of the 100-K Area, Hanford Site, South-Central Washington. WHC-SD-EN-TI-155, Westinghouse Hanford Company, Richland, Washington. 
Lindsey, K. A. 1992. Geology of the Northern Part of the Hanford Site: An Outline of Data Sources and the Geologic Setting of the 100 Areas. WHC-SD-EN-TI-011, Rev. 0, Westinghouse Hanford Company, Richland, Washington.

Lindsey, K. A., B. N. Bjornstad, J. W. Lindberg, and K. M. Hoffman. 1992. Geologic Setting of the 200 East Area: An Update. WHC-SD-EN-TI-012, Westinghouse Hanford Company, Richland, Washington.

Lindsey, K. A., and G. K. Jaeger. 1993. Geologic Setting of the 100-HR-3 Operable Unit, Hanford Site, South-Central Washington. WHC-SD-EN-TI-132, Westinghouse Hanford Company, Richland, Washington.

Lindsey, K. A. 1995. Miocene- to Pliocene-Aged Suprabasalt Sediments of the Hanford Site, South-Central Washington. BHI-00184, Rev. 00, Bechtel Hanford, Inc., Richland, Washington.

Luttrell, S. P., D. R. Newcomer, S. S. Teel, and V. R. Vermeul. 1992. Hydrogeologic Controls on Ground-Water and Contaminant Discharge to the Columbia River Near the Hanford Townsite. PNL-8167, Pacific Northwest Laboratory, Richland, Washington.

McMahon, W. J., and R. E. Peterson. 1992. Estimating Aquifer Hydraulic Properties Using the Ferris Method, Hanford Site, Washington. DOE/RL-92-64, U.S. Department of Energy, Richland, Washington.

Moench, A. F. 1994. "Specific Yield as Determined by Type-Curve Analysis of Aquifer-Test Data." Ground Water 32(6):949-957.

Neuman, S. P., and S. Yakowitz. 1979. "A Statistical Approach to the Inverse Problem of Aquifer Hydrology, 1, Theory.” Water Resources Research 15(4):845-860.

Newcomb, R. C., and J. R. Strand. 1953. Geology and Ground-Water Characteristics of the Hanford Reservation of the U.S. Atomic Energy Commission, Washington. U.S. Geological Survey Administrative Report WP-8, U.S. Geological Survey, Washington, D.C. 
Newcomb, R. C., and S. G. Brown. 1961. Evaluation of Bank Storage Along the Columbia River Between Richland and China Bar, Washington. Water-Supply Paper 1539-I, U.S. Geological Survey, Washington, D.C.

Newcomer, D. R., L. A. Doremus, S. H. Hall, M. J. Truex, V. R. Vermeul, and R. E. Engelman. 1995. Geology, Hydrology, Chemistry, and Microbiology of the In Situ Bioremediation Demonstration Site. PNL-10422, Pacific Northwest Laboratory, Richland, Washington.

Peterson, R. E. 1992. Hydrologic and Geologic Data Available for the Region North of Gable Mountain, Hanford Site, Washington. WHC-SD-EN-TI-006, Westinghouse Hanford Company, Richland, Washington.

Prater, L. S., J. T. Rieger, C. S. Cline, E. J. Jensen, and T. L. Liikala. 1984. Ground-Water Surveillance at the Hanford Site for CY-1983. PNL-5041, Pacific Northwest Laboratory, Richland, Washington.

Puget Sound Power and Light (PSPL). 1982. Skagit/Hanford Nuclear Project, Preliminary Safety Analysis Report. Appendix 20, Amendment 23, Puget Sound Power and Light Company, Bellevue, Washington.

PSPL (see Puget Sound Power and Light)

Rehfeldt, K. R., and L. W. Gelhar. 1992. "Stochastic Analysis of Dispersion in Unsteady Flow in Heterogeneous Aquifers," Water Resources Research 28(8):2085-2089.

Reidel, S. P., K. A. Lindsey, and K. R. Fecht. 1992. Field Trip Guide to the Hanford Site. WHC-MR-0391, Westinghouse Hanford Company, Richland, Washington.

Schalla, R., R. W. Wallace, R. L. Aaberg, S. P. Airhart, D. J. Bates, J. V. M. Carlile, C. S. Cline, D. I. Dennison, M. D. Freshley, P. R. Heller, E. J. Jensen, K. B. Olsen, R. G. Parkhurst, J. T. Rieger, and E. J. Westergard. 1988. Interim Characterization Report for the 300 Area Process Trenches. PNL-6716, Pacific Northwest Laboratory, Richland, Washington. 
Simmons, C. S., C. T. Kincaid, and A. E. Reisenauer. 1986. A Simplified Model for Radioactive Contaminant Transport: The TRANSS Code. PNL-6029, Pacific Northwest Laboratory, Richland, Washington.

Spane, Jr., F. A., and R. G. Raymond. 1993. Preliminary Potentiometric Map and Flow Dynamic Characteristics for the Upper-Basalt Confined Aquifer System. PNL-8869, Pacific Northwest Laboratory, Richland, Washington.

Spane, Jr., F. A. 1993. Selected Hydraulic Test Analysis Techniques for Constant-Rate Discharge Tests. PNL-8539, Pacific Northwest Laboratory, Richland, Washington.

Spane, Jr., F.A. 1994. Applicability of Slug Interference Tests for Hydraulic Characterization of Unconfined Aquifers: (1) Analytical Assessment. PNL-SA-24283, Pacific Northwest Laboratory, Richland, Washington.

Spane, Jr., F. A., and V. R. Vermeul. 1994. Summary and Evaluation of Hydraulic Property Data Available for the Hanford Site Upper Basalt Confined Aquifer System. PNL-10158, Pacific Northwest Laboratory, Richland, Washington.

Spane, Jr., F. A., and W. D. Webber. 1995. Hydrochemistry and Hydrogeologic Conditions Within the Hanford Upper Basalt Confined Aquifer System. PNL-10817, Pacific Northwest Laboratory, Richland, Washington.

Swanson, L. C. 1992. Phase I Hydrogeologic Summary of the 300-FF-5 Operable Unit, 300 Area. WHC-SD-EN-TI-052, Westinghouse Hanford Company, Richland, Washington.

Thorne, P. D., and D. R. Newcomer. 1992. Summary and Evaluation of Available Hydraulic Property Data for the Hanford Site Unconfined Aquifer System. PNL-8337, Pacific Northwest Laboratory, Richland, Washington.

Thorne, P. D., and M. A. Chamness. 1992. Status Report on the Development of a ThreeDimensional Conceptual Model for the Hanford Site Unconfined Aquifer System. PNL-8332, Pacific Northwest Laboratory, Richland, Washington. 
Thorne, P. D., M. A. Chamness, F. A. Spane Jr., V. R. Vermeul, and W. D. Webber. 1993. ThreeDimensional Conceptual Model for the Hanford Site Unconfined Aquifer System, FY 93 Status Report. PNL-8971, Pacific Northwest Laboratory, Richland, Washington.

Thorne, P. D., M. A. Chamness, V. R. Vermeul, Q. C. Macdonald, and S. E. Schubert. 1994. Three-Dimensional Conceptual Model for the Hanford Site Unconfined Aquifer System: FY 1994 Status Report. PNL-10195, Pacific Northwest Laboratory, Richland, Washington.

U.S. Department of Energy (DOE). 1987. Final Environmental Impact Statement, Disposal of Hanford Defense High-Level, Transuranic and Tank Waste, Hanford Site, Richland, Washington. DOE/EIS-0113, Vol. 1-5, U.S. Department of Energy, Richland, Washington.

U.S. Department of Energy (DOE). 1988. Consultation Draft, Site Characterization Plan, Reference Repository Location, Hanford Site, Washington. DOE/RW-0164, Vol. 1 and 2, U.S. Department of Energy, Richland, Washington.

U.S. Department of Energy (DOE). 1991. Description of Codes and Models to be Used in Risk Assessment. DOE/RW-9144, U.S. Department of Energy, Richland, Washington.

van der Kamp, G., L. D. Luba, J. A. Cherry, and H. Maathuis. 1994. "Field Study of a Long and Very Narrow Contaminant Plume." Ground Water 32:6 (1008-1016).

Vermeul, V. R., S. S. Teel, J. E. Amonette, C. R. Cole, J. S. Fruchter, Y. A. Gorby, F. A. Spane, J. E. Szecsody, M. D. Williams, and S. B. Yabusaki. 1995. Geologic, Geochemical, Microbiologic, and Hydrologic Characterization at the In Situ Redox Manipulation Test Site. PNL-10633, Pacific Northwest Laboratory, Richland, Washington.

Walters, W. H., M. C. Richmond, and B. G. Gilmore. 1994. Reconstruction of Radionuclide Concentrations in the Columbia River from Hanford, Washington to Portland, Oregon January 1950-January 1971. PNWD-2225 HEDR.

Westinghouse Hanford Company (WHC). 1990. Travel Time Estimates for Altemative Tritium Crib Locations, Hanford Site, Washington. WHC-SD-EN-EE-002, prepared by Golder Associates for Westinghouse Hanford Company, Richland, Washington. 
Westinghouse Hanford Company (WHC). 1993. Westinghouse Hanford Company Operational Groundwater Status Report, 1990-1992. WHC-EP-0595, Westinghouse Hanford Company, Richland, Washington.

WHC (see Westinghouse Hanford Company)

Whelan, G., D. L. Strenge, J. G. Droppo, Jr., and B. L. Steelman. 1987. The Remedial Action Priority System (RAPS): Mathematical Formulations. PNL-6200, Pacific Northwest Laboratory, Richland, Washington.

Wurstner, S. K. and J. L. Devary. 1993. Hanford Site Ground-Water Model: Geographic Information System Linkages and Model Enhancements, FY 1993. PNL-8991. Pacific Northwest Laboratory, Richland, Washington.

Wurstner, S. K. and M. D. Freshley. 1994. Predicted Impacts of Future Water Level Decline on Monitoring Wells Using a Ground-Water Model of the Hanford Site. PNL-10196. Pacific Northwest Laboratory, Richland, Washington. 
-

-

- 


\section{Appendix A}

Analysis of a Richland City Well Pumping Test 
-

•

• 


\section{Appendix A}

\section{Analysis of a Richland City Well Pumping Test}

This appendix describes the analysis of aquifer tests conducted at a new water supply well installed by the city of Richland. The well is located on the west side of Wellsian Way near the intersection with Lee Boulevard. English units have been used in this appendix because test data were collected using English units. Analysis results have been converted to metric units.

\section{Test Site Hydrogeology}

Geology at the pumping well consists of a sandy-mud confining layer to a depth of $31 \mathrm{ft}$, Hanford formation gravel and sand from $31 \mathrm{ft}$ to $43 \mathrm{ft}$, and Ringold Formation sandy gravel with some silt from 43 to $54 \mathrm{ft}$. A clay layer was encountered at $54 \mathrm{ft}$. The static piezometric head in the well was approximately $8.5 \mathrm{ft}$ below ground surface. However, water was not observed entering the borehole until a depth of $31 \mathrm{ft}$ was reached.

\section{Test Description}

The pumping well is 12 in. in diameter and is screened within the Ringold Formation from 45 to $54 \mathrm{ft}$ below ground surface. However, sand pack placed around the screen extends up into the Hanford formation sediments to a depth of about $38 \mathrm{ft}$. Drawdown was monitored at an observation well located $84.5 \mathrm{ft}$ away. The observation well consists of a 4-in. diameter borehole completed with 2-in. PVC tubing and a 2-in. PVC screen from 27 to $51 \mathrm{ft}$ below ground surface.

Figure A.1 shows hydraulic head changes recorded in the observation well throughout the 19 day pretest and test period. Both the measured water level change and the change corrected for an apparent downward trend are shown on the figure. The upper line represents the corrected water-level data. Water level in the observation well was measured by a pressure transducer (0-10 psi range) that was vented to the atmosphere to automatically compensate for barometric pressure fluctuations. The transducer measurements were automatically recorded by a data logger. Each of the three short-duration pumping events that appear during the first 10,000 min shown on Figure A. 1 lasted about $30 \mathrm{~min}$.

Two sustained pumping and recovery events were conducted. Flow rate during the two sustained pumping periods was estimated at $1020 \mathrm{gal} / \mathrm{min}$. The first pumping event lasted a total of $1828 \mathrm{~min}$. However, the pump was turned off for $6 \mathrm{~min}$, then back on for $55 \mathrm{~min}$ at the end of the pumping phase. Recovery was monitored for $3950 \mathrm{~min}$. The early part of the second sustained pumping period was interrupted twice. After $23 \mathrm{~min}$ of pumping, the pump was off for $104 \mathrm{~min}$. The pump was then on for $255 \mathrm{~min}$ and off for $48 \mathrm{~min}$ before running continuously for the next $5865 \mathrm{~min}$. The final recovery period lasted $3813 \mathrm{~min}$.

\section{Pretest Water-Level Monitoring}

Data plotted in Figure A.1 prior to the first sustained pumping test indicates a downward trend of about $2.2 \times 10^{-5} \mathrm{ft} / \mathrm{min}$ throughout the period prior to the first sustained pumping period. It was assumed that this trend continued throughout the pumping and recovery phases. Therefore, data were corrected for this trend prior to analysis. Water-level change over the first $3000 \mathrm{~min}$ 
(Figure A.2) was analyzed using the method in Clark (1967) to determine the effect of barometric pressure changes on the water level in the observation well and to calculate a barometric efficiency for the aquifer. The barometric response was small and resulted in a barometric efficiency of 0.218 . Although confined aquifers generally have higher barometric efficiency values, the calculated value is possible for a non rigid and/or discontinuous confining layer.

\section{Diagnostic Analysis of Drawdown Response}

Figure A.3 shows a log-log diagnostic plot of the first pumping period. Derivatives of the drawdown data and of the type curve were calculated as described in Spane and Wurstner (1992) and plotted on the figure. The response during the first pumping period is similar to the other recovery and pumping periods shown in later figures. The last $61 \mathrm{~min}$ of the pumping period is not shown in the plot because the pump was turned off for 6 min then on again for $55 \mathrm{~min}$.

A constant derivative value indicates infinite-acting radial flow conditions that can be analyzed using the semilog straight-line technique (see Spane 1993). The "valley" in the derivative response is typical of unconfined aquifer delayed-yield conditions. However, a similar response can also be caused by other non ideal well and aquifer conditions such as the influence of a no-flow boundary, leakage from a confining layer, or aquifer heterogeneity. In this case, the response does not appear to be caused by unconfined aquifer delayed yield because both straight-line analysis and type-curve analysis of the late-time data resulted in storage values that are too low to reflect aquifer specific yield. The calculated values are less than $1 \times 10^{-4}$ and are in the expected range of elastic storativity for a confined aquifer. Geologic evidence also indicates that the aquifer is confined. However, the low barometric efficiency indicates that the aquifer is not isolated from atmospheric pressure changes by a rigid impermeable layer.

The response was also evaluated for a possible no-flow boundary in the vicinity of the well. A no-flow boundary condition would normally cause the derivative to stabilize at a value of about 1 , then increase to about 2 when the effect of the boundary became dominant. Under these conditions, the type curve would also be expected to fit the earlier time drawdown data, which was not possible because the drawdown response was flattened compared to the Theis curve. Therefore, the response does not appear to reflect a no-flow boundary.

The flattening of the early drawdown response, which results in the valley in the derivative, could be caused by a decrease in flow rate during early pumping. Detailed records of flow rate versus time are not available, and it is common for pumping rate to decrease as drawdown increases in the well. The early drawdown response may also be caused by leakage from the confining layer, or by the composite nature of the aquifer. The aquifer is composed of a highly permeable Hanford formation layer and a deeper, less permeable, Ringold formation layer. The well is screened in only the deeper Ringold interval. However, sandpack material extends up partially through the Hanford interval. Partial penetration of the pumping well was evaluated by calculating type curves for this condition. The resulting deviation from the Theis response at the observation well was insignificant for a homogeneous aquifer. However, the composite aquifer combined with the partially penetrating pumping well could not be simulated.

\section{Analysis of First Pumping Period}

A type curve analysis of the first pumping period is shown in Figure A.4. Transmissivity calculated by matching with the Theis curve was $13,500 \mathrm{ft} 2 / \mathrm{d}$ and storativity was $5 \times 10^{-5}$. Late time data was used for the type curve analysis because of the atypical early time response. Later time 
data is also expected to be more representative of the aquifer response than early data, which is affected more by well completion conditions and near-well heterogeneities. A straight-line analysis is shown in Figure A.5. The line was fitted to data after 1565 min of pumping. Calculated transmissivity was $18,000 \mathrm{ft} 2 / \mathrm{d}$ and storativity was $1.2 \times 10^{-5}$. These values are consistent with the type-curve results.

\section{Analysis of First Recovery Period}

Figure A.6 shows type curve analysis of the first recovery period. The recovery data were plotted against the time function of Agarwal (1980), which compensates for the effects of the preceding pumping period so that drawdown type curves can be applied to recovery data. Transmissivity calculated by matching with the Theis curve was $14,000 \mathrm{ft} 2 / \mathrm{d}$ and storativity was $5 \times 10^{-5}$. Late time data was again used for the type curve analysis because of the atypical early time response. The recovery period was longer than the pumping period and data after about $600 \mathrm{~min}$ has a relatively constant derivative that indicates infinite-acting radial flow conditions. A straight-line analysis of the first recovery period is shown in Figure A.7. The calculated transmissivity was $14,700 \mathrm{ft}^{2} / \mathrm{d}$ and the storativity was $2.9 \times 10^{-5}$. These values are consistent with the type-curve results.

\section{Analysis of Second Pumping Period}

Type curve analysis of the second pumping period is shown in Figure A.8. Early interruptions in pumping are apparent. However, these do not have a large effect on the late time response. A change in pumping rate also occurred between 4368 and $4388 \mathrm{~min}$. This does not show up on the log-log plot and did not significantly affect the type-curve match, but the corresponding decrease in drawdown can be seen on the semilog plot in Figure A.9.

Transmissivity calculated by matching with the Theis curve was $13,500 \mathrm{ft} 2 / \mathrm{d}$ and storativity was $5 \times 10^{-5}$. Late time data was used for the type curve analysis because of the atypical early time response. The analysis results were identical to the type curve match of drawdown data from the first pumping period. A straight-line analysis is shown in Figure A.9. The line was fit to data from 3100 to $4360 \mathrm{~min}$, before the apparent change in pumping rate. Calculated transmissivity was $15,600 \mathrm{ft} 2 / \mathrm{d}$ and storativity was $9.2 \times 10^{-5}$.

\section{Analysis of Second Recovery Period}

Figure A.10 shows type curve analysis of the second recovery period. The data were plotted against the time function of Agarwal (1980), which compensates for the effects of the preceding pumping period. Transmissivity calculated by matching with the Theis curve was $14,500 \mathrm{ft} 2 / \mathrm{d}$ and storativity was $5 \times 10^{-5}$. Late time data was used for the type curve analysis because of the atypical early time response. The derivative did not stabilize at late time. Therefore, radial flow conditions were not established and no straight-line analysis was performed.

\section{REFERENCES}

Agarwal, R. G. 1980. A New Method to Account for Producing Time Effect When Drawdown Type Curves are Used to Analyze Pressure Buildup and Other Test Data. SPE Paper 9289, Soc. of Pet. Engrs., Richardson, Texas. 
Clark, W. E. 1967. "Computing the Barometric Efficiency of a Well." In Proceedings of the American Society of Civil Engineers, Journal of the Hydraulics Division, Vol. 43(HY4), pp. 93-98.

Spane, Jr., F. A. 1993. Selected Hydraulic Test Analysis Techniques for Constant-Rate Discharge Tests. PNL-8539, Pacific Northwest Laboratory, Richland, Washington.

Spane, Jr., F. A. and S. K. Wurstner. 1992. DERIV: A Program for Calculating Pressure Derivatives For Hydrologic Test Data. PNL-SA-21569, Pacific Northwest Laboratory, Richland, Washington. 


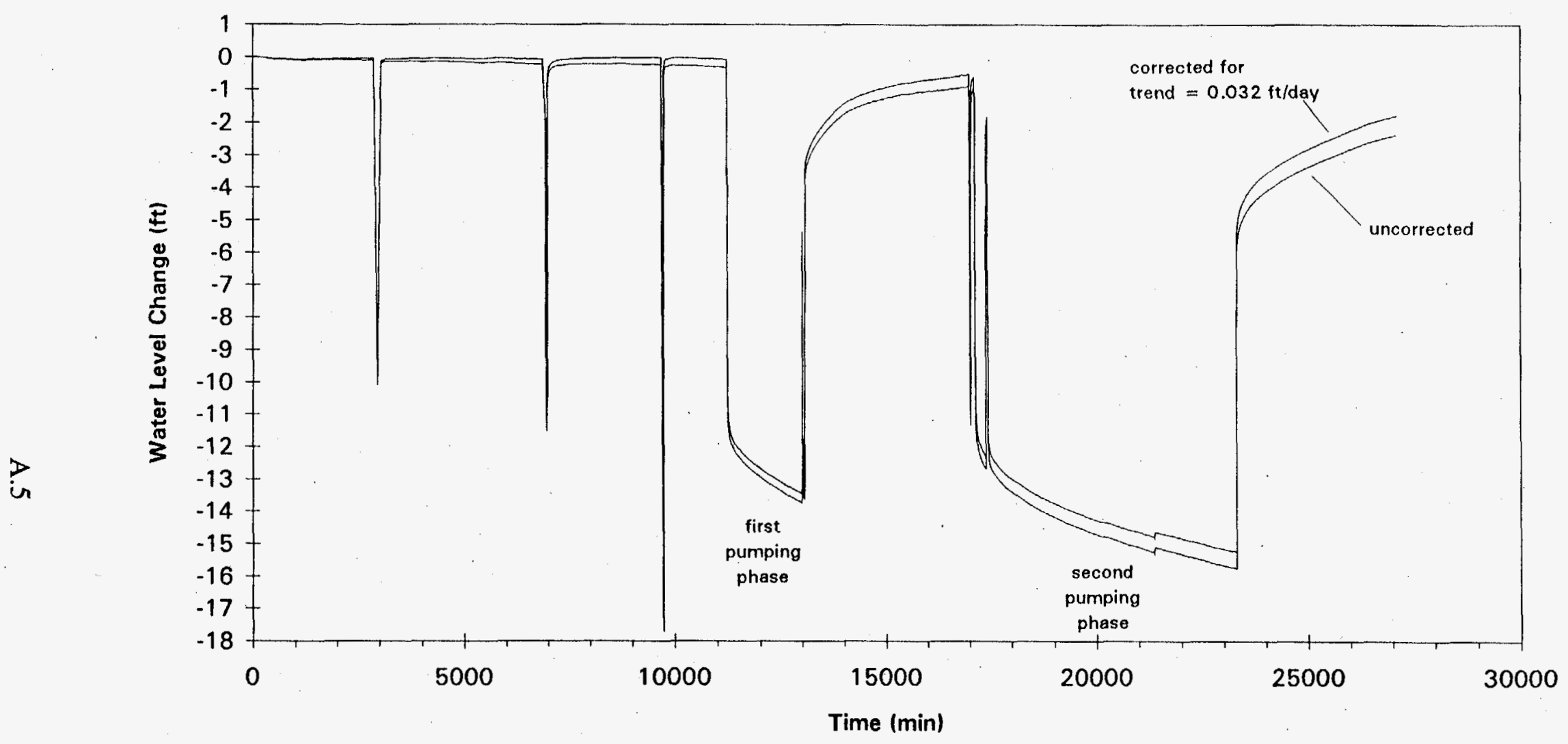

Figure A.1. Uncorrected and Corrected Hydraulic Head Measured at the Observation Well During the Pretest and Test Periods 


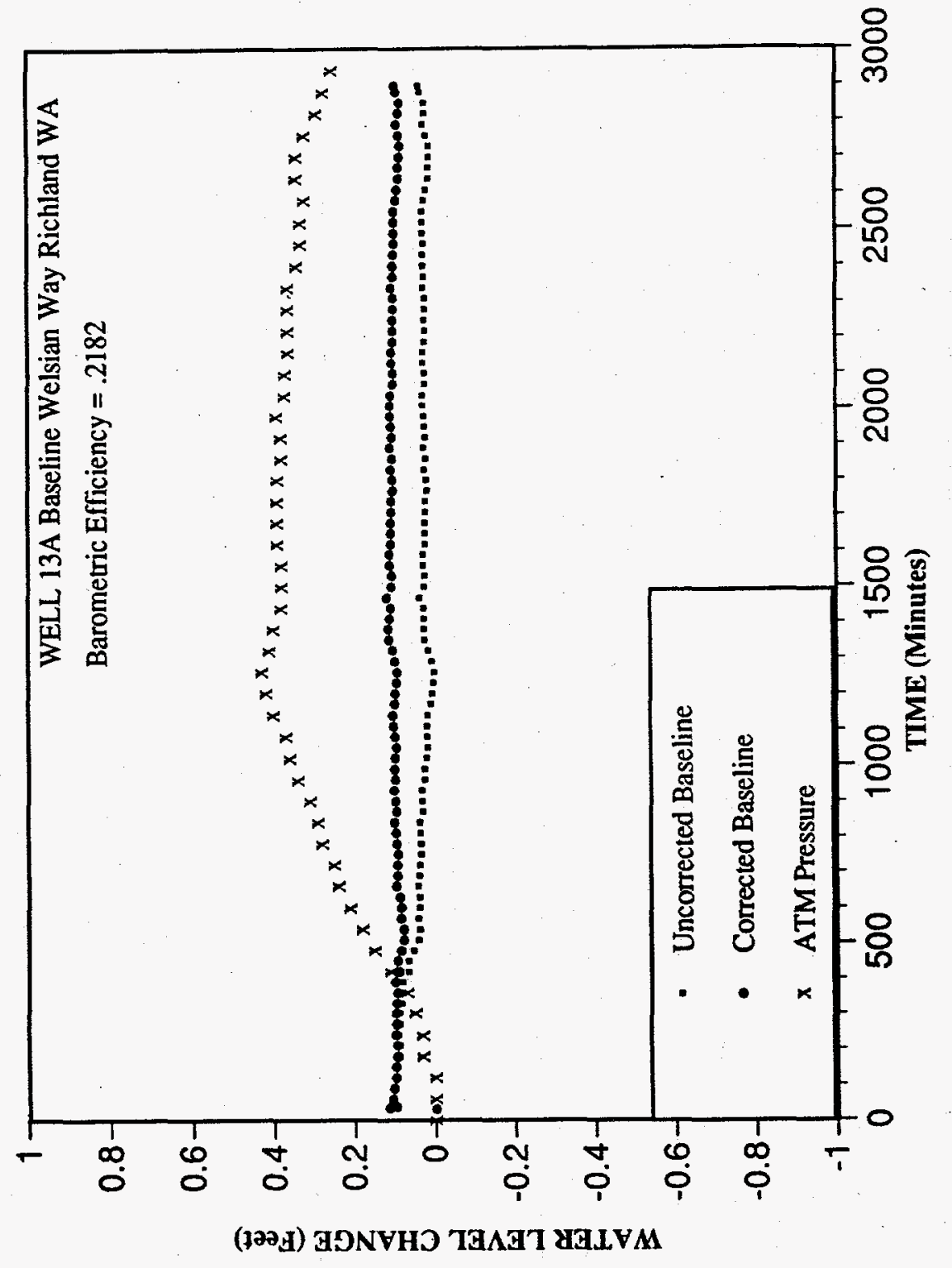





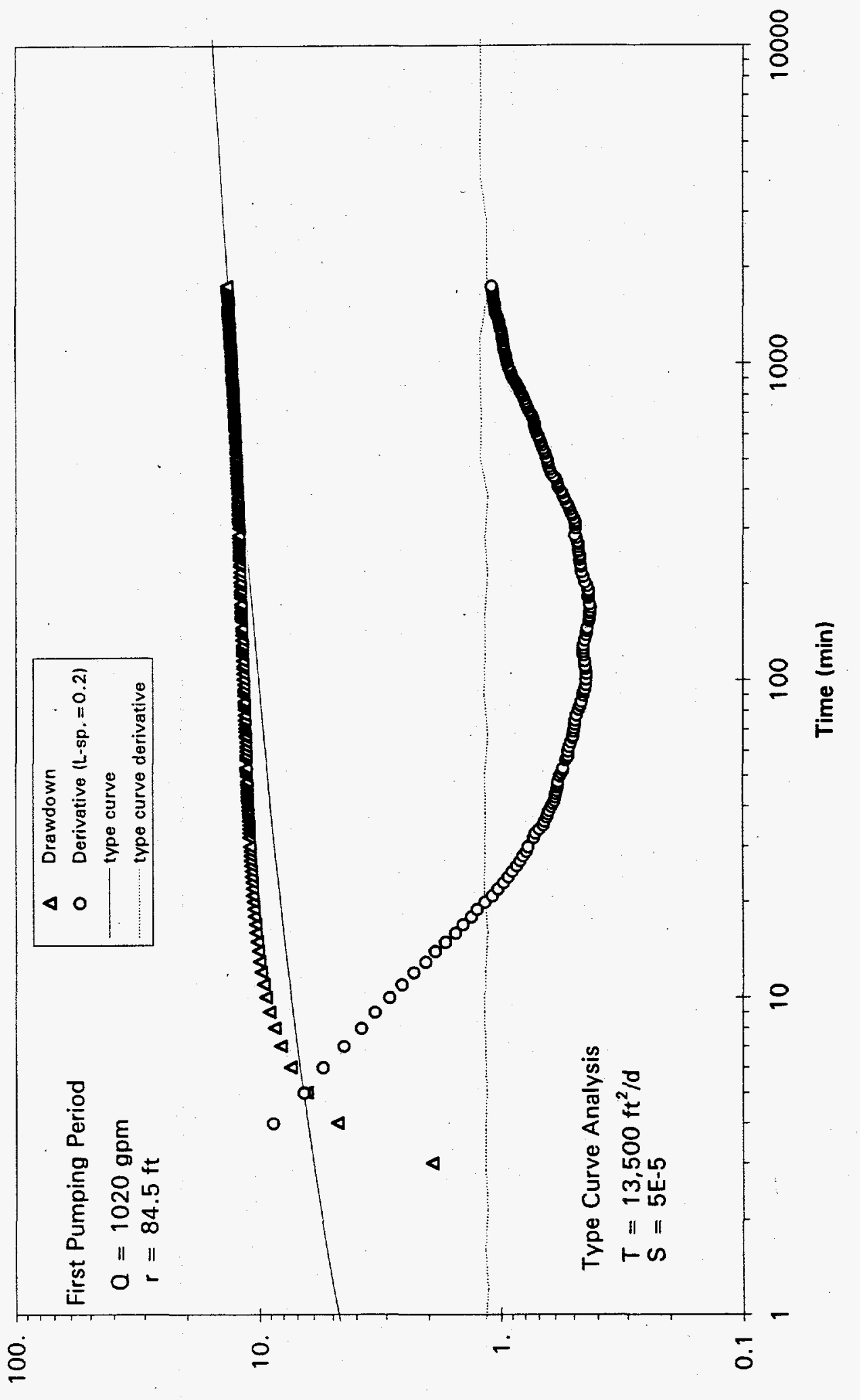

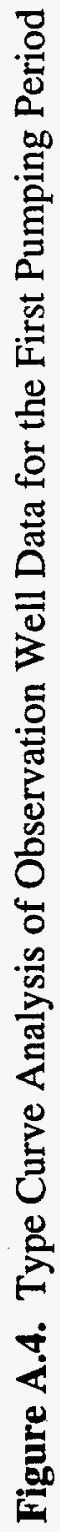

(ł) имормеда 


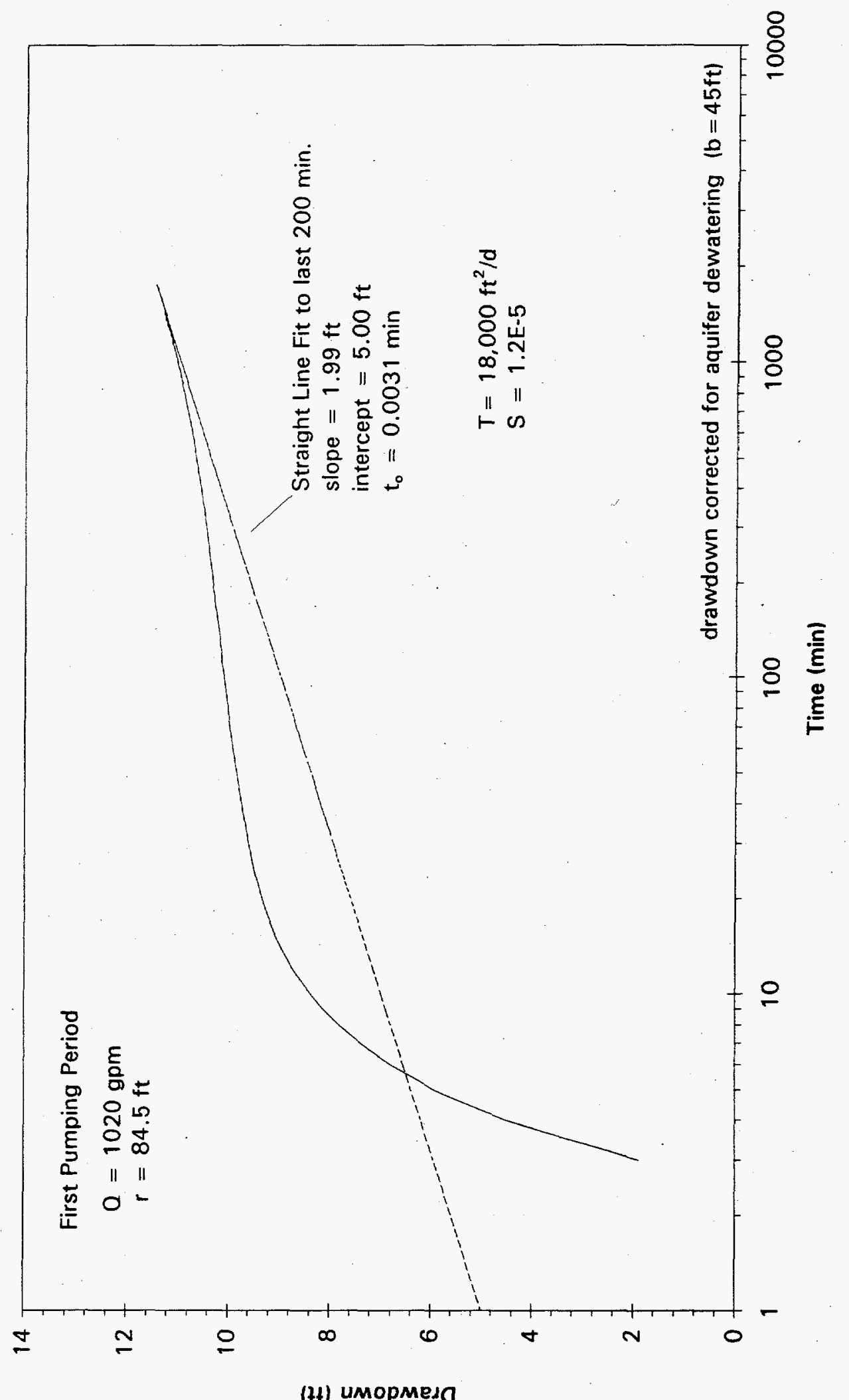

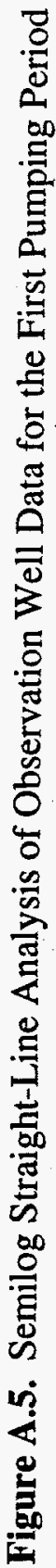

A. 9 


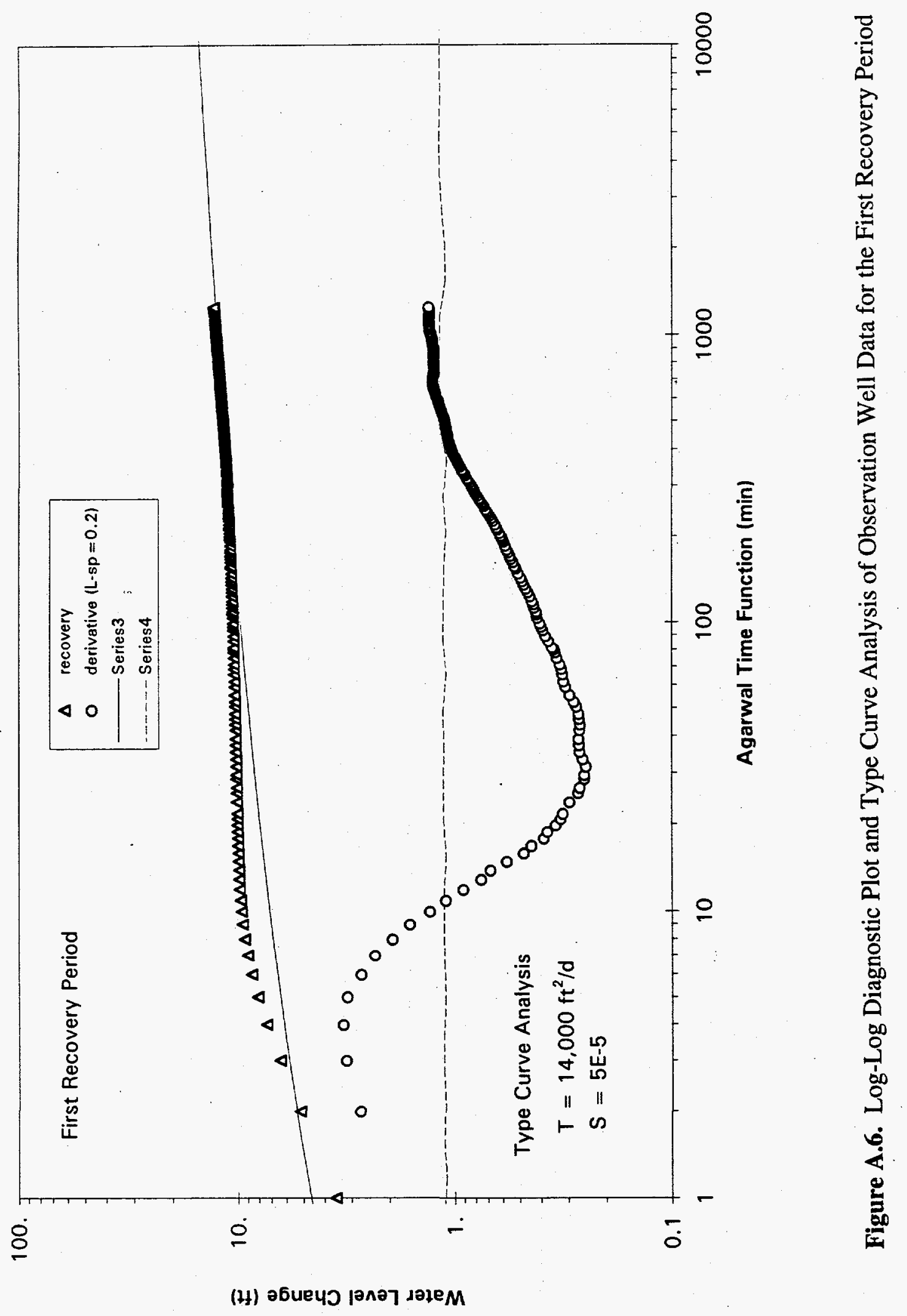

A. 10 


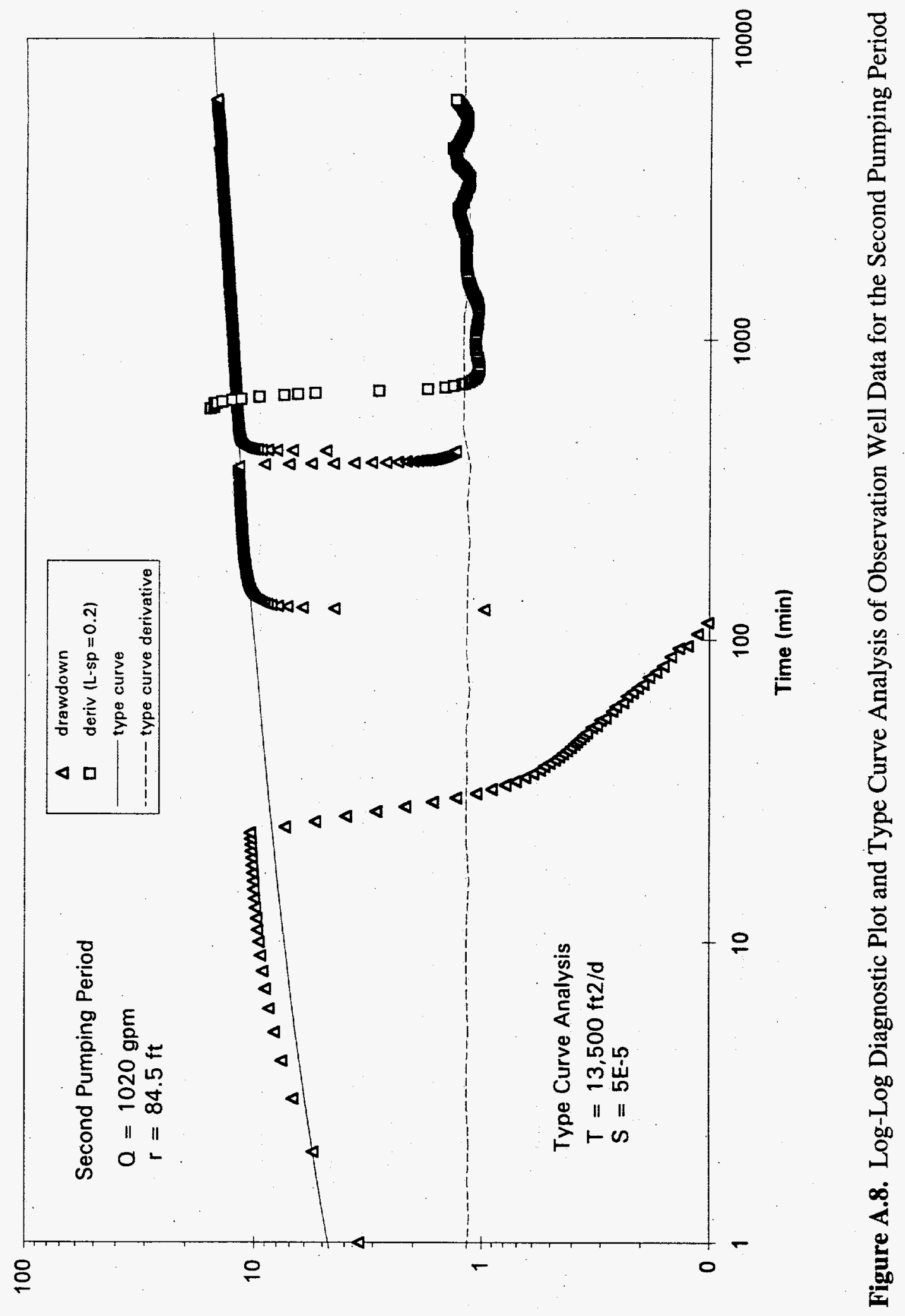

(H) имормеs 


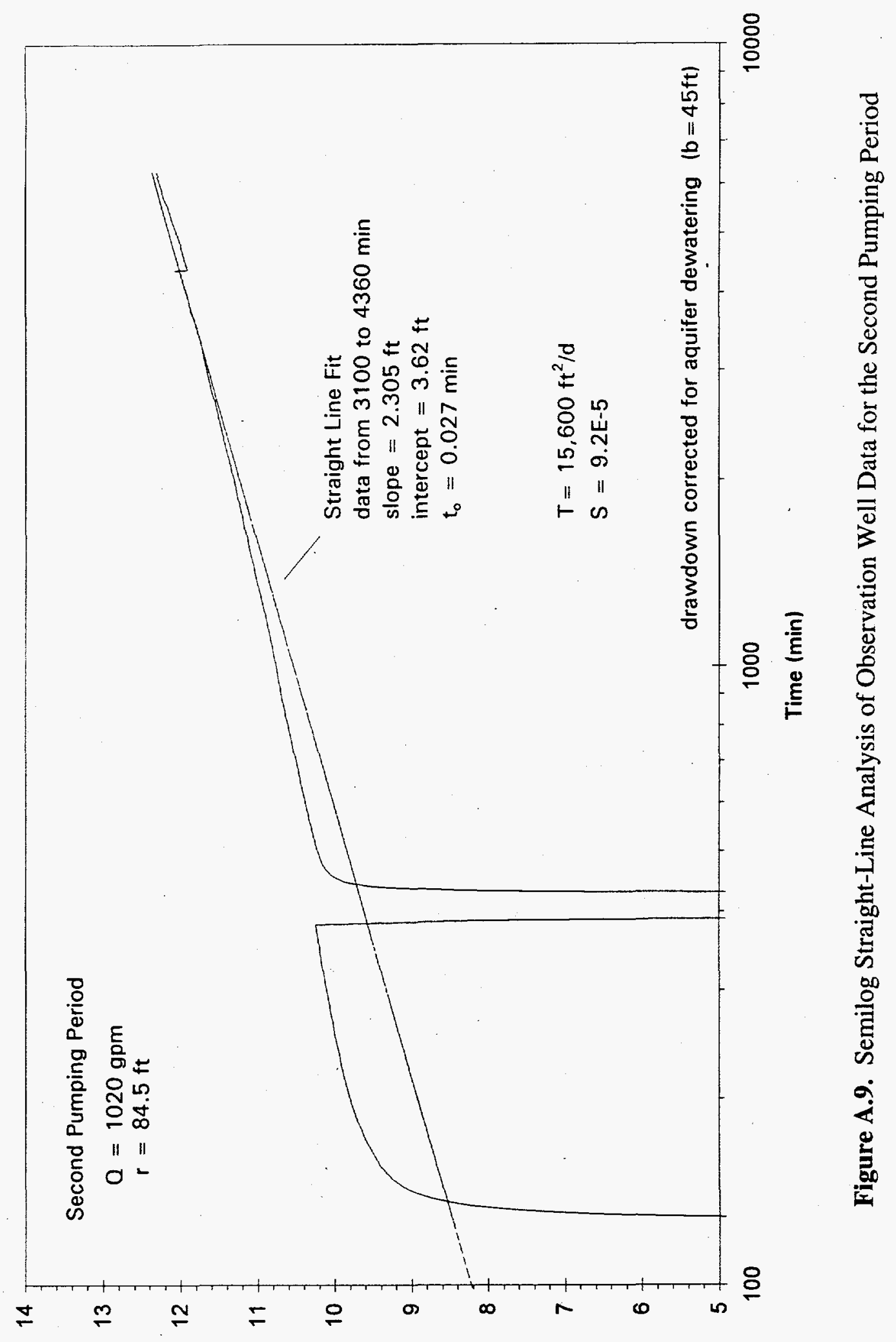

(f) имормеда 


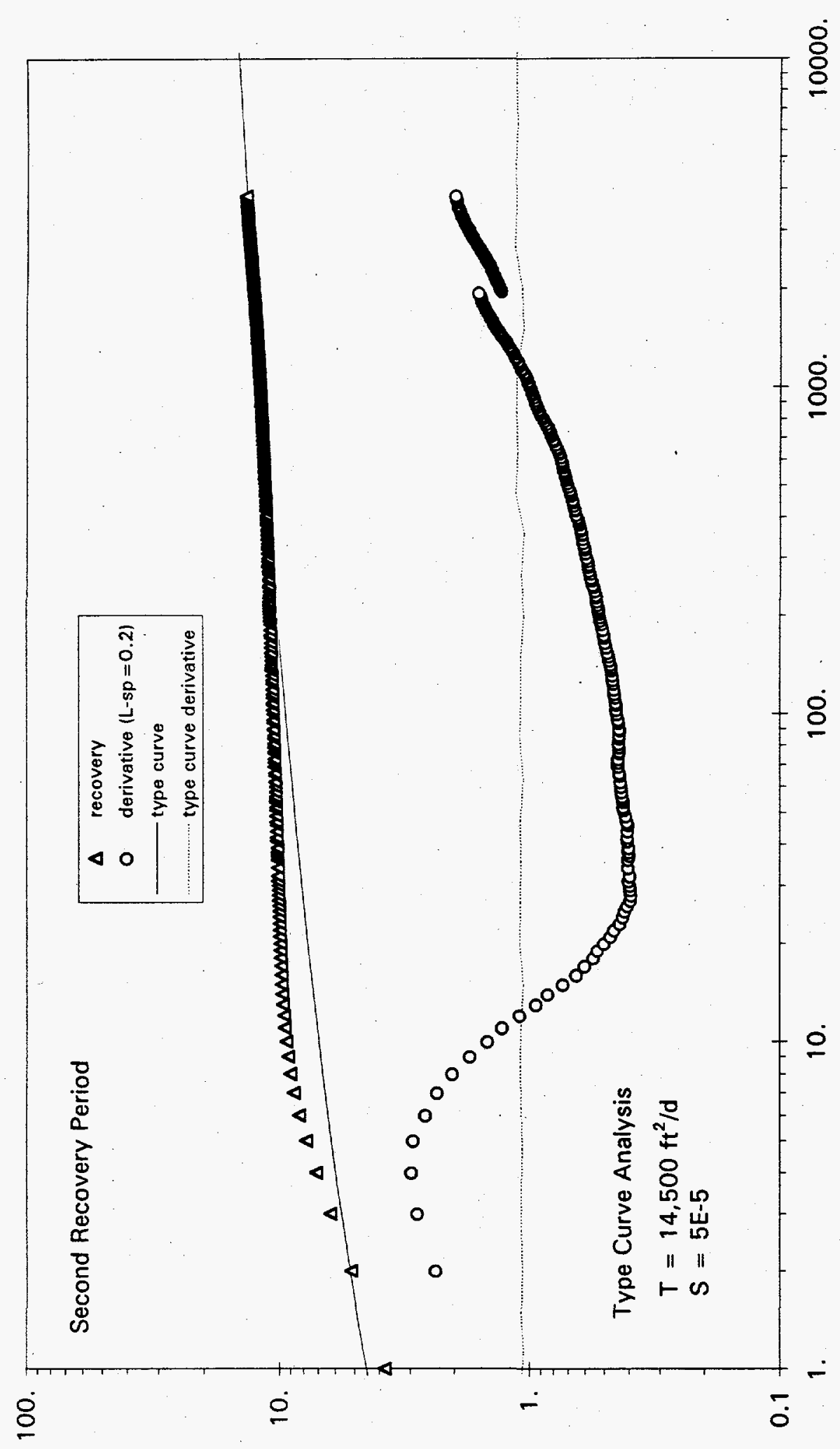

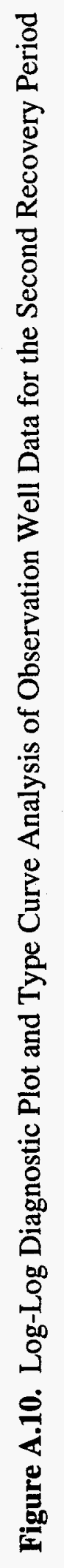

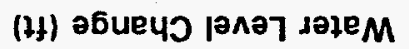


Appendix B

Analysis of the 200-West Area Ground-Water Mound 


\section{Appendix B}

\section{Analysis of the 200-West Area Ground-Water Mound}

Mounding of ground water near liquid disposal sites provides an opportunity for estimating aquifer hydraulic properties. The mound beneath the 200-West Area began to dissipate following the decommissioning of U Pond in 1984. The change in the volume of this ground-water mound from 1985 through 1993 was analyzed to estimate effective porosity of the upper unconfined aquifer system. Estimates of aquifer transmissivity were obtained from a steady-state analysis of the mound configuration in 1984 and from transient analysis of mound dissipation following the decommissioning of U Pond. Newcomb and Strand (1953) performed similar analyses for the initial buildup of the ground-water mound. Observed dissipation of the 200-West Area mound was also compared to that predicted by a modeling study presented in Hall (1981).

\section{Calculation of Aquifer Specific Yield}

Specific yield of the unconfined aquifer can be calculated from the ground-water mound dissipation by dividing the volume of aquifer dewatered during a period of time by the reduction in the volume of water recharged to the aquifer over that same time period. This assumes that the mound configuration was relatively stable prior to the reduction in aquifer recharge. The time period selected for analysis was January 1985 through December 1994. The level of the mound decreased during this period because of the decommissioning of U Pond, which occurred in the early 1980s. Figure B.1 shows water levels measured in four 200-West Area wells since 1982. Water levels in these wells began to decline at about the beginning of 1985 .

Figure B. 2 shows the average combined discharge to waste water disposal facilities in the 200-West Area for each year from 1975 through 1994. The average discharge rate from 1975 through 1984 was $7816 \mathrm{~L} / \mathrm{min}$ and the average discharge from 1985 through 1995 was $1817 \mathrm{~L} / \mathrm{min}$. During 1985 through 1995, the total discharge in the 200-West Area was $31,530,000 \mathrm{~m}^{3}$ less than the total discharge during the preceding $10 \mathrm{yr}$ period. The resulting decrease in water table elevations from 1985 to 1995 is shown in Figure B.3. This figure was analyzed to estimate the volume of aquifer that was dewatered during this period. As summarized in Table B.1, the area within each contour line was estimated using the formula for the area (A) of an ellipse:

$$
\mathrm{A}=\pi \mathrm{ab}
$$

where $\mathrm{a}$ and $\mathrm{b}$ are the elliptical radii.

The average water-level change within each contour was then multiplied by the area within that contour minus the area within the next higher contour. These volumes were summed to determine the total dewatered aquifer volume according to the following formula:

$$
V_{T}=\sum_{j=1}^{n}\left[\left(A_{j}-A_{j+1}\right)\left(h_{j+1}-h_{j}\right) / 2\right]
$$


Table B.1. Calculation of the Volume of the 200-West Area Mound Dewatered from 1985 through 1995

\begin{tabular}{||c|c|r|r|r|r|r||}
\hline \hline \multirow{2}{*}{ Contour } & Water-Level & \multicolumn{2}{|c|}{ Ellipse Dimensions } & Area Within & & Dewatered \\
\cline { 2 - 5 } & Decline, $\mathrm{h}_{\mathrm{n}}$ & \multicolumn{1}{|c|}{$2 \mathrm{a}$} & \multicolumn{1}{c|}{$2 \mathrm{~b}$} & Contour, $\mathrm{A}_{\mathrm{n}}$ & $\mathrm{A}_{\mathrm{n}}-\mathrm{A}_{\mathrm{n}+1}$ & Volume \\
\hline $\mathrm{n}$ & $(\mathrm{m})$ & $(\mathrm{m})$ & \multicolumn{1}{c|}{$(\mathrm{m})$} & \multicolumn{1}{c|}{$\left(\mathrm{m}^{3}\right)$} & \multicolumn{1}{c|}{$\left(\mathrm{m}^{3}\right)$} & $\left(\mathrm{m}^{3}\right)$ \\
\hline 1 & 0 & 16,000 & 11,000 & $138,160,000$ & $75,360,000$ & $37,680,000$ \\
\hline 2 & 1 & 10,000 & 8,000 & $62,800,000$ & $34,736,250$ & $52,104,375$ \\
\hline 3 & 2 & 6,500 & 5,500 & $28,063,750$ & $12,952,500$ & $32,381,250$ \\
\hline 4 & 3 & 5,500 & 3,500 & $15,111,250$ & $10,275,650$ & $35,964,775$ \\
\hline 5 & 4 & 2,800 & 2,200 & $4,835,600$ & $2,794,600$ & $12,575,700$ \\
\hline 6 & 5 & 2,000 & 1,300 & $2,041,000$ & 981,250 & $5,396,875$ \\
\hline 7 & 6 & 1,500 & 900 & $1,059,750$ & 745,750 & $4,847,375$ \\
\hline 8 & 7 & 800 & 500 & 314,000 & 314,000 & $1,099,000$ \\
\hline & & & & Total $=$ & $182,049,350 \mathrm{~m}^{3}$ \\
\hline
\end{tabular}

Where $h_{j}=$ water-level change corresponding to the $j$ th contour, $A_{j}=$ estimated area within the $j$ th contour with $A_{n+1}=0$, and the water-level change contours are closed and concentric and are numbered inward from 1 to $\mathrm{n}$.

Analysis of Figure B.3 estimated that $182,049,350 \mathrm{~m}^{3}$ of the aquifer was dewatered during the 10-yr period from 1985 to 1995 . Dividing by the reduction in the volume of effluent resulted in a calculated specific yield of 0.17. Newcomb and Strand (1953) analyzed the volume of mound growth beneath both the 200-West Area and 200-East Area between 1948 and 1953 to estimate effective porosities of 0.11 for both mounds. Water levels beneath the 200-West Area had increased by an additional 5 to $10 \mathrm{~m}$ from 1953 to 1985 . Therefore, the difference in porosity could be caused by a difference in the sediments saturated during the 1953 to 1985 period compared to those during 1985 to 1995.

\section{Calculation of Transmissivity}

Aquifer transmissivity was calculated from the 200-West Area mound using the following rearrangement of Darcy's Law:

$$
\mathrm{T}=\frac{\mathrm{Q}}{\mathrm{I} \mathrm{L}}
$$

where $Q=$ flow rate across a closed contour line

$\mathrm{I}=$ average hydraulic gradient at the contour line

$\mathrm{L}=$ length around closed contour line. 
This analysis assumes steady state flow conditions. That is, water recharged in the center of the mound at rate $\mathrm{Q}$ is assumed to cause water to flow across the selected closed contour line at rate $\mathrm{Q}$. There is no change in storage within the ground-water mound. Hydrographs in Figure B.1 show that the water table was relatively stable in 1984, before water levels began to fall in response to the decreased discharge. Therefore, the steady-state analysis was applied using the water table configuration measured in December 1984 (Figure B.4). As shown in Figure B.4, the mound was divided into 16 segments, and a gradient was calculated for each segment at the $145 \mathrm{~m}$ contour line. The average gradient at the $145 \mathrm{~m}$ contour line was 0.0022 . Length of the $145 \mathrm{~m}$ contour line was approximately $10,000 \mathrm{~m}$, and the average discharge of waste water in the 200 -West Area during 1984 was $7200 \mathrm{~m}^{3} / \mathrm{d}$, applying the above formula results in a calculated transmissivity of $327 \mathrm{~m}^{2} / \mathrm{d}$.

\section{Previous Studies of the 200-West Mound}

Newcomb and Strand (1953) calculated a transmissivity of about $300 \mathrm{~m}^{2} / \mathrm{d}$ from the 200 West Area mound configuration in 1953. Because the mound was actually growing during this period (Zimmerman et al. 1986), the flow rate across the contour may have been less than the discharge rate, Q, used in Newcomb and Strand's (1953) calculation. This would result in a lower calculated value for transmissivity. Another source of uncertainty in the mound analysis is the effective aquifer thickness to which the calculated transmissivity applies. Because of the layered nature of the sediments within the Ringold Formation, vertical hydraulic conductivity is lower than horizontal hydraulic conductivity and most of the flow within the mound probably occurs in the upper part of the aquifer where the recharge is applied. Therefore, the transmissivity calculated from the mound analyses may be lower than the transmissivity of the entire aquifer thickness.

Hall (1981) used a numerical flow model to predict the impact of U Pond decommissioning, which had been proposed at that time, on water table elevations in the vicinity of the 200-West Area. Hall assumed a nondistributed hydraulic conductivity of $7 \mathrm{~m} / \mathrm{d}$ and a storativity (actually specific yield) of 0.2 for the model domain. The transmissivity varied with the aquifer's saturated thickness and ranged up to $550 \mathrm{~m} 2 / \mathrm{d}$. The model was used to predict water table elevations from 1982 through 1989 based on the assumed cessation of discharge to U Pond. A maximum water table decline of over $10 \mathrm{~m}$ was predicted to occur within $7 \mathrm{yr}$. The actual maximum decline in the water table during the $7 \mathrm{yr}$ period following U Pond decomissioning has been about $7 \mathrm{~m}$. This indicates that the actual transmissivity is lower than that assumed in Hall's model. However, the model was two dimensional and assumed that the entire aquifer thickness was effective in mound dissipation. Again, because of low vertical hydraulic conductivity, mound dissipation may have been slower than that predicted even if the transmissivity was correct for the entire aquifer thickness.

According to Hall (1981), the average discharge to U Pond had been in the range of 5000 to $13,000 \mathrm{~L} / \mathrm{min}$ for each of the $10 \mathrm{yr}$ prior to 1982 . The only discharges within the 200 -West Area that were assumed to continue beyond 1982 were at the 216-S-11 Pond and the 216-S-19 Pond. The combined total discharge that was assumed to continue at these facilities was about $450 \mathrm{~L} / \mathrm{min}$. However, as shown in Figure B.2, total discharges in the 200-West Area from 1985 through 1992 averaged around about $2000 \mathrm{~L} / \mathrm{min}$. This difference may also account for the difference between the change in water levels predicted by Hall (1981) and the actual observed change. 


\section{REFERENCES}

Hall, M. D. 1981. Near Field Impact of 216-U-10 (U-Pond) Decommissioning on the Unconfined Aquifer. RHO-LD-157, Rockwell Hanford Operations, Richland, Washington.

Newcomb, R. C., and J. R. Strand. 1953. Geology and Ground-Water Characteristics of the Hanford Reservation of the U.S. Atomic Energy Commission, Washington. U.S. Geological Survey Administrative Report WP-8, U.S. Geological Survey, Washington, D.C.

Zimmerman, D. A., A. E. Reisenauer, G. D. Black and M. A. Young. 1986. Hanford Site Water Table Changes 1950 Through 1980 - Data Observations and Evaluation. PNL-5506, Pacific Northwest Laboratory, Richland, Washington. 


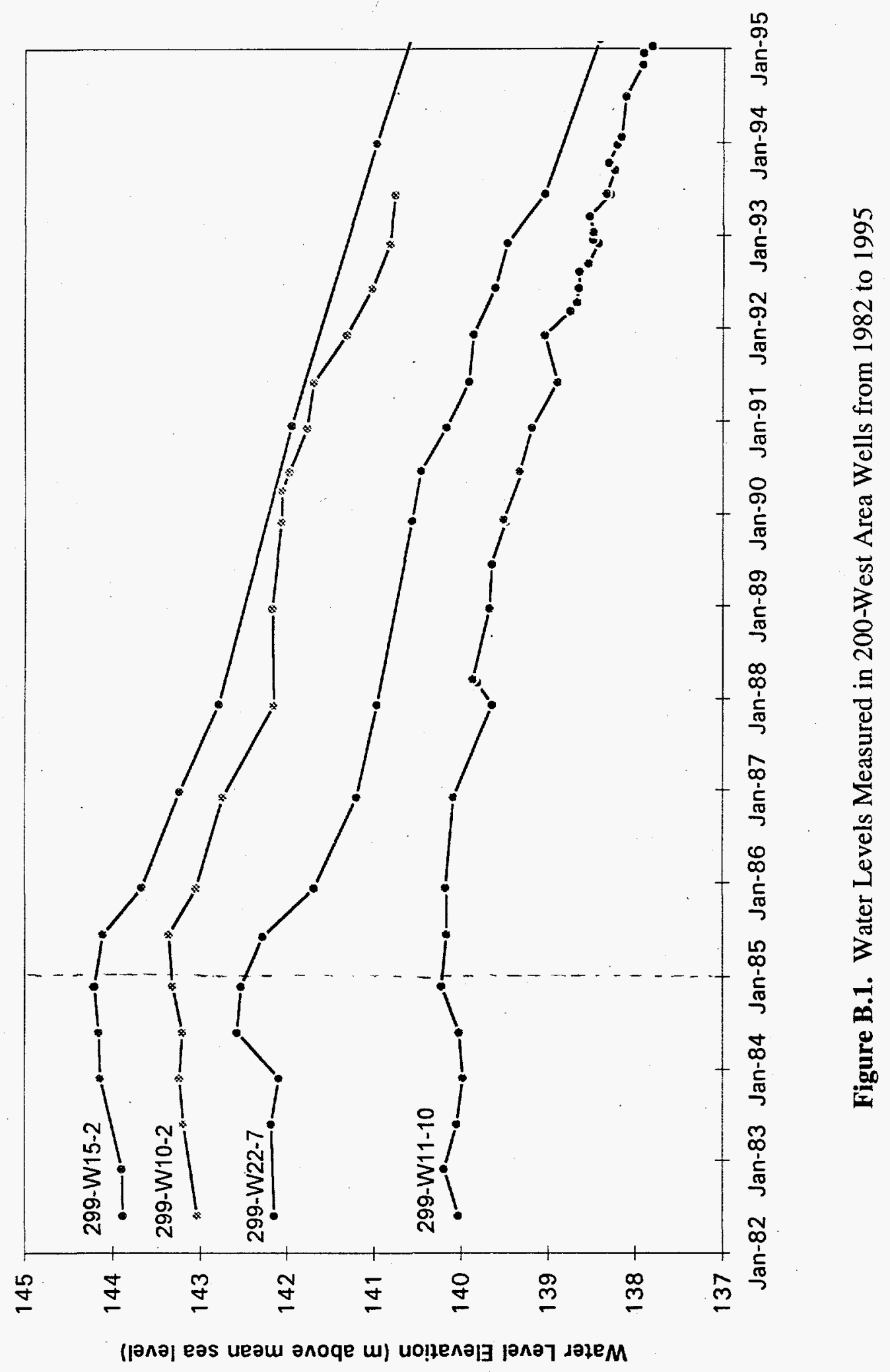

B. 5 


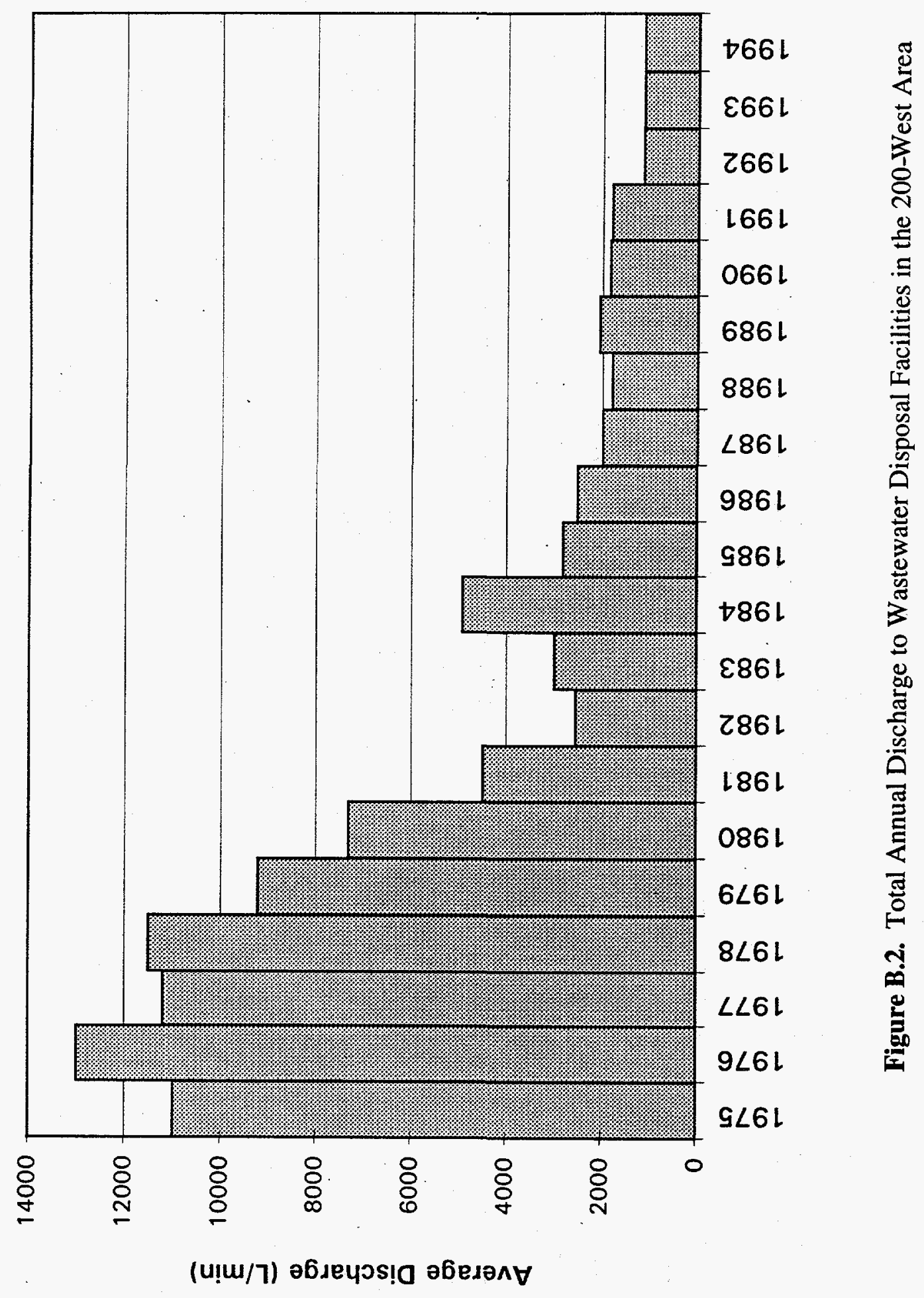

B. 6 


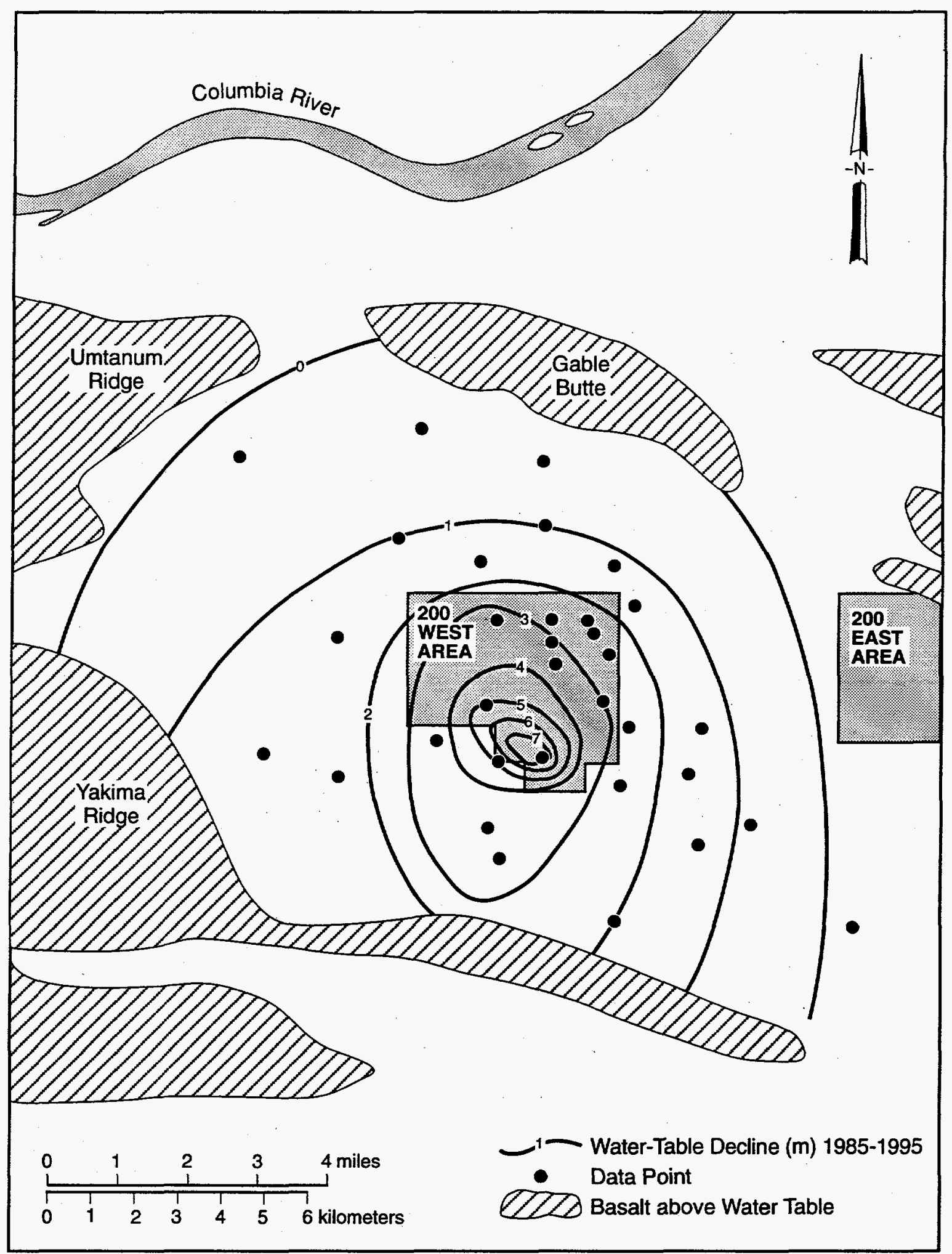

SG95100614.2

Figure B.3. Decrease in Water Table Elevation near the 200-West Area from 1985 to 1995 


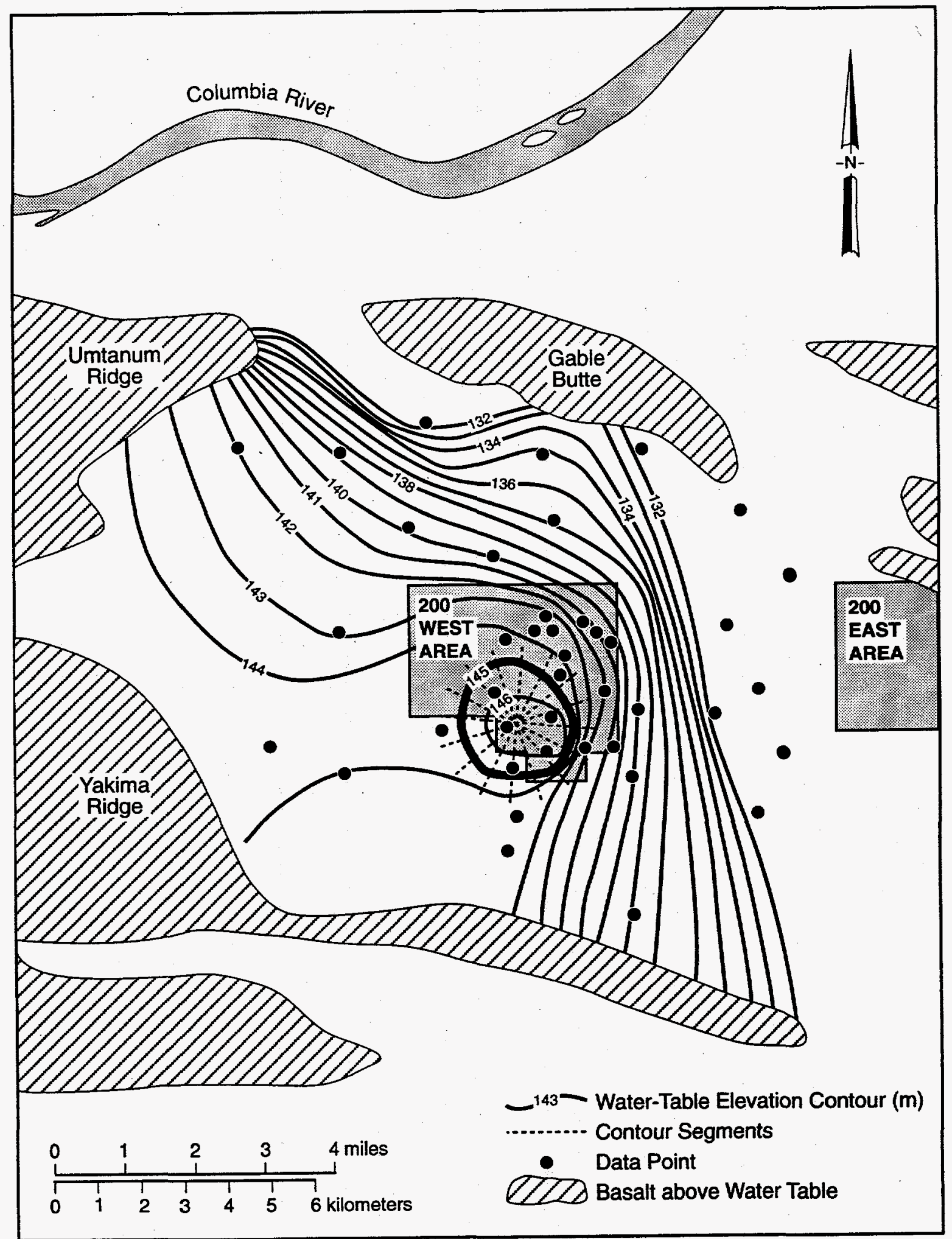

SG95100614.1

Figure B.4. Water Table Elevations near the 200-West Area in 1984 Showing the Segments Used for Calculating Average Gradient Across the $145 \mathrm{~m}$ Contour Line 


\section{Appendix C}

\section{Available Transmissivity Data Obtained from Pumping Tests in the Unconfined Aquifer System}




\begin{tabular}{|c|c|c|c|c|c|c|c|c|c|c|c|c|c|c|}
\hline & & & Water & scrn & sarn & ser top & scr bot & Sat & Hanf & Sat & Sat & Sat & U-5/19 & \\
\hline & & Casing & Table & top & bot & below & below & Hant & Estimated & U.5 & $\mathrm{U.7}$ & U.9 & Estimated & \\
\hline & Best T & Elev. & Elev. & depth & depth & water & water & Thick & $\mathrm{K}$ & Thick & Thick & Thick & $\mathrm{K}$ & comments \\
\hline Well Number & $\ln 2 / d)$ & (m) & $(m)$ & (m) & $(\mathrm{m})$ & $(m)$ & (m) & $(m)$ & $(\mathrm{m} / \mathrm{d})$ & (m) & (m) & {$[\mathrm{ml}$} & $(\mathrm{m} / \mathrm{d})$ & \\
\hline 199-D2-6 & 500 & 140.2 & 116.7 & 11.0 & 26.2 & $(12.5)$ & 2.7 & 3 & 182 & & & & & \\
\hline 199-D8-3 & 6320 & 145.1 & 125.9 & 10.7 & 24.1 & $(8.5)$ & 4.9 & 0 & & 11 & & & 560 & geo for D8-6 \\
\hline $199-\mathrm{F} 7-1$ & 735 & 118.8 & 114.8 & 3.0 & 42.7 & $(0.9)$ & 38.7 & 3 & 225 & & & & & \\
\hline $199-\mathrm{H} 3-2 \mathrm{~A}$ & 3770 & 127.4 & 114.4 & 11.0 & 15.5 & (2.0) & 2.6 & & & & & & & lno geo \\
\hline $199+44-3$ & 180 & 128.1 & 116.2 & 10.4 & 16.8 & (1.5) & 4.9 & 3 & 52 & 2 & & & & \\
\hline $199 \cdot \mathrm{H} 4-10$ & 4970 & 123.1 & 113.7 & 7.0 & 11.6 & $(2.4)$ & 2.2 & 3 & 1792 & & & & & \\
\hline $199-\mathrm{H} 4-11$ & 100 & 127.1 & 113.6 & 11.6 & 16.2 & (1.8) & 2.7 & & & & & & & no geo \\
\hline $199+H 4-12 \mathrm{~A}$ & 260 & 125.9 & 113.6 & 10.1 & 14.6 & (2.2) & 2.4 & 6 & 41 & 0 & 14 & & & geo for $12 \mathrm{C}$ \\
\hline $199+44-14$ & 100 & 128.2 & 114.3 & 11.6 & 16.2 & (2.3) & 2.3 & & & & & & & no geo \\
\hline 199-H4-16A & 217 & 124.1 & 113.8 & 8.2 & 12.8 & (2.0) & 2.5 & 4 & 57 & 10 & 6 & & & geo for $15 \mathrm{C}$ \\
\hline $199-\mathrm{K} 10$ & 418 & 142.2 & 118.6 & 47.2 & 50.3 & 23.6 & 26.7 & 0 & & 27 & & & 16 & \\
\hline $199-N-14$ & 300 & 138.1 & 121.6 & 13.7 & 23.8 & $(2.7)$ & 7.3 & 1 & 246 & & & & & \\
\hline $199-N-16$ & 600 & 139.0 & 121.6 & 15.2 & 23.8 & (2.1) & 6.4 & & & & & & & nogeo \\
\hline $189-\mathrm{N}-32$ & 524 & 140.8 & 122.6 & 13.4 & 24.4 & (4.9) & 6.1 & & & & & & & no geo \\
\hline $299-W 7-1$ & 111 & 210.5 & 141.6 & 68.6 & 74.7 & (0.3) & 5.8 & 0 & & $?$ & & & 519 & \\
\hline 299-W7-2 & 69 & 205.9 & 139.5 & 61.6 & 67.7 & (4.8) & 1.3 & 0 & & $?$ & & & $<54$ & \\
\hline $299-W 7-4$ & 280 & 204.7 & 140.8 & 61.9 & 71.0 & (2.0) & 7.1 & 0 & & $?$ & & & $<39$ & \\
\hline $299-W 7-6$ & 16 & 205.1 & 140.8 & 63.3 & 68.4 & $(1.0)$ & 5.1 & 0 & & $?$ & & & $<3$ & \\
\hline $299-W 7-6$ & 3.7 & 206.8 & 140.4 & 63.7 & 67.7 & $(2.7)$ & 1.2 & 0 & & $?$ & & & $<3$ & \\
\hline 299-W10-13 & 326 & 213.1 & 143.6 & 69.2 & 76.4 & $(0.3)$ & 6.0 & 0 & & $?$ & & & $<54$ & \\
\hline $299-W_{1} 1-30$ & 93 & & & & & & & & & & & & & no geo \\
\hline 299-W1E.15 & 930 & 212.7 & 142.4 & 68.0 & 77.7 & (2.4) & 7.4 & 0 & & $?$ & & & $<126$ & \\
\hline $299 \cdot W 16-16$ & 1120 & 208.8 & 143.4 & 63.4 & 72.5 & (2.0) & 7.2 & 0 & & $?$ & & & $<156$ & \\
\hline $299-W 16-18$ & 1300 & 209.0 & 144.2 & 63.4 & 73.2 & (1.4) & 8.4 & 0 & & $?$ & & & $<155$ & \\
\hline $299-W 18-21$ & 4740 & 203.8 & 142.5 & 59.6 & 68.7 & $(1.7)$ & 7.4 & 0 & & $?$ & & & $<640$ & \\
\hline $299-W 18-23$ & 2320 & 212.4 & 144.1 & 67.1 & 76.6 & (1.2) & 8.2 & 0 & & $?$ & & & $<282$ & \\
\hline $299-W 18-24$ & 1580 & 208.6 & 144.0 & 62.6 & 73.2 & (1.9) & 8.6 & 0 & & $?$ & & & $<184$ & \\
\hline $299-W \times 21-1$ & 2700 & 213.1 & 139.7 & 67.1 & 88.4 & (6.4) & 14.9 & 0 & & $?$ & & & $<181$ & \\
\hline 299-E18-1 & 66 & 219.5 & 126.1 & 93.9 & 101.2 & $(0.5)$ & 6.8 & & & & & & & no geo \\
\hline 299-E18-2 & 186 & 219.8 & 124.6 & 94.2 & 100.6 & (1.1) & 5.3 & & & & & & & Ino geo \\
\hline 299-E18-3 & 279 & 2201 & 125.3 & 94.2 & 100.6 & $(0.6)$ & 5.8 & & & & & & & ino geo \\
\hline $299 \cdot E 26-22$ & 186 & 205.4 & 123.1 & 80.8 & 89.9 & $(1.5)$ & 7.6 & & & & & & & Ino geo \\
\hline $299-E 25-34$ & $\geq 23000$ & 202.0 & 124.5 & 76.8 & 82.9 & $(0.8)$ & 5.3 & & & & & & & nogeo \\
\hline $299-E 25-35$ & $>7400$ & 2056 & 125.0 & 79.4 & 85.6 & $(1.2)$ & 5.1 & & & & & & & no oeo \\
\hline $299-E 27-8$ & $>6300$ & 194.4 & 124.5 & 68.7 & 78.3 & $(1.2)$ & 8.4 & & & & & & & nogeo \\
\hline 299-E27-9 & 3250 & 191.7 & 124.3 & 67.1 & 74.4 & $(0.3)$ & 7.0 & & & & & & & no geo \\
\hline $299-E 27-10$ & 3250 & 190.2 & 124.0 & 64.6 & 73.2 & $(1.6)$ & 6.9 & & & & & & & no geo \\
\hline $299-E 28-16$ & 12600 & 213.7 & 123.7 & & & & & & & & & & & nogeo \\
\hline 299-E28-27 & $>4460$ & $207 . \overline{4}$ & 124.1 & 82.3 & 91.7 & $(1.0)$ & 8.5 & 2 & $>2230$ & & & & & \\
\hline $298-E 32-4$ & $>880$ & 209.0 & 123.6 & 84.7 & 93.9 & 0.7 & 8.4 & 5 & $>176$ & & & & & \\
\hline $299-\mathrm{E} 33-28$ & $>4900$ & 202.5 & 124.0 & 78.0 & 84.7 & 0.4 & 6.3 & 7 & $>700$ & & & & & \\
\hline 298-E33-29 & $>4700$ & 205.4 & 124.4 & 80.2 & 88.4 & $(0.8)$ & 7.4 & 0 & & & & & & \\
\hline $299-E 33-30$ & $>5200$ & 202.3 & 123.8 & 77.7 & $B 4.4$ & $(0.8)$ & 5.9 & 6 & $>860$ & & & & & \\
\hline $298-E 34-2$ & 10600 & 192.3 & 124.1 & 67.1 & 73.2 & $(1.1)$ & 5.0 & 5 & 2010 & & & & & \\
\hline 299-E34-3 & 1300 & 186.4 & 124.5 & 58.8 & 65.2 & (3.1) & 3.3 & 3 & 409 & & & & & \\
\hline $399-1-10 \mathrm{~A}$ & 18600 & 113.9 & 104.6 & 7.0 & 11.9 & $(2.4)$ & 2.5 & & & & & & & no geo \\
\hline $399-1-13 A$ & 10200 & 118.5 & 104.4 & 11.6 & 16.2 & (2.4) & 2.1 & & & & & & & no geo \\
\hline $399-1-14 A$ & 17700 & 116.8 & 104.8 & 9.4 & 14.3 & $(2.6)$ & 2.3 & & & & & & & no geo \\
\hline $399-1-16 A$ & 930 & 116.5 & 104.5 & 9.8 & 14.6 & $(2.2)$ & 2.7 & 2 & 535 & 22 & & & & geo for $16 \mathrm{C}$ \\
\hline $399-1.18 A$ & 9290 & 118.3 & 104.0 & 11.6 & 16.5 & $2.7)$ & 2.1 & T & & 20 & 0 & 6 & & $0 e 0$ for $18 \mathrm{C}$ \\
\hline $399-8-2$ & 3710 & 120.7 & 104.4 & 13.1 & 32.3 & $(3.2)$ & 16.0 & 0 & & 5. & 3 & & 463 & \\
\hline $499-51.7 A$ & 177 & 168.9 & 118.6 & 50.3 & 61.0 & $(0.0)$ & 10.6 & D & & $?$ & & & & \\
\hline $499-51.7 B$ & 650 & 168.9 & 114.4 & 70.1 & 85.3 & 15.6 & 30.9 & 1 & 650 & $?$ & & & & \\
\hline 699-\$30-E15A & 13700 & 122.0 & 106.1 & 17.7 & 23.8 & 0.8 & 6.9 & 4 & 3524 & $?$ & & & & \\
\hline 699-S27-E9A & $280-370$ & 118.3 & 106.8 & 10.7 & 16.8 & (0.8) & 5.3 & 0 & & 11 & 12 & & $12-16$ & geo for S27-E9C \\
\hline 699-\$27-E9D & 367 & 118.3 & 106.1 & 11.9 & 21.3 & $(0.3)$ & 9.1 & 0 & & 10 & 12 & & 17 & geo for S27-E9C \\
\hline 699-\$22-E9B & 279 & 113.1 & 106.6 & 41.8 & 46.1 & 35.1 & 38.5 & 1 & 276 & 6 & 10 & & & geo for S22-E9C \\
\hline 699-\$22-E9D & $232-325$ & 113.1 & 104.9 & 7.9 & 91.6 & (0.3) & 3.2 & 0 & & 5 & 10 & & 15-22 & geo lor S22-E9C \\
\hline 699-s19-11 & 360 & 147.4 & 113.7 & 28.7 & 36.1 & $(5.1)$ & 1.3 & & & & & & & no geo \\
\hline 699-S18-E2A & 287 & 132.6 & 109.0 & 21.3 & 73.2 & (2.3) & 49.5 & 0 & & 39 & & & 7 & \\
\hline $699-514-20$ & 490 & 150.2 & 122.6 & 27.4 & 48.8 & $(0.2)$ & 21.2 & & & & & & & no geo \\
\hline $699-512-3$ & 26 & 132.7 & i15.2 & 16.8 & 33.5 & $(0.8)$ & 16.0 & 0 & & 16 & & & 2 & \\
\hline $699-\$ 8-19$ & 846 & 153.6 & 120.2 & 31.7 & 40.2 & (1.7) & 6.8 & 1 & 1180 & $?$ & & & & \\
\hline 699-53-26 & 88 & 159.7 & 121.2 & 34.7 & 52.4 & (3.8) & 13.9 & 0 & & $?$ & & & & \\
\hline $699-1 \cdot 18$ & 930 & 164.0 & 120.6 & 33.2 & 80.8 & $(10.2)$ & 37.4 & D & & 56 & & & 17 & \\
\hline $699-2-3$ & 2040 & 145.4 & 118.1 & 25.9 & 37.6 & (1.4) & 10.2 & 2 & 1260 & $?$ & & & & \\
\hline $699-2-7$ & 973 & 156.1 & 118.6 & 44.2 & 60.3 & 6.7 & 12.8 & 1 & 1615 & $?$ & & & & \\
\hline $699-2-33 A$ & 424 & 163.4 & 122.8 & 39.6 & 137.2 & (1.0) & 96.6 & 0 & & 19 & 39 & 17 & 6 & \\
\hline $699-4-E 6$ & $>14000$ & 152.4 & 131.7 & 20.4 & 26.4 & $(0.3)$ & 5.7 & & & & & & & no geo \\
\hline $699-8-17$ & 9290 & 159.2 & 120.8 & 32.8 & 48.2 & (5.5) & 9.8 & 20 & 473 & & & & & \\
\hline $699-8-32$ & 102 & 169.0 & 121.4 & 46.7 & 56.1 & $(1.8)$ & 8.5 & & & & & & & no geo \\
\hline $699-10-64 \mathrm{~A}$ & 900 & 157.4 & 126.5 & 31.4 & 37.5 & 0.5 & 6.6 & 0 & & 22 & & & 41 & \\
\hline $699-11-46 A$ & 280 & 176.2 & 124.8 & 61.8 & .67 .1 & 0.4 & 15.6 & 0 & & 17 & 0 & 32 & 6 & \\
\hline $699-16-16 B$ & 84 & 167.1 & 121.3 & 43.0 & 49.1 & (2.9) & 3.2 & & & & & & & no geo \\
\hline $699-16-26$ & 6600 & 159.7 & 121.7 & 36.6 & 45.7 & (1.4) & 7.8 & 31 & 210 & $?$ & & & & \\
\hline
\end{tabular}

C. 1 


\begin{tabular}{|c|c|c|c|c|c|c|c|c|c|c|c|c|c|c|}
\hline & & & Water & scrn & sern & scr top & serbot & Sat & Hani & Sat & Sat & Sat & U-5/719 & \\
\hline & & Casing & Table & top & bot & below & below & Hant & Estimated & U.5 & $\mathrm{U}-7$ & U.9 & Estimated & \\
\hline & Best T & Elev. & Elev. & depth & depth & water & water & Thick & $\mathrm{K}$ & Thick & Thick & Thick & $\mathbf{K}$ & comments \\
\hline Well Number & $\{\mathrm{m} 2 / \mathrm{d}\}$ & $\ln \mid$ & $(m)$ & $(m) !$ & $(m)$ & $(\mathrm{m})$ & $(m)$ & {$[\mathrm{m})$} & $(\mathrm{m} / \mathrm{d})$ & {$[\mathrm{m}]$} & $(m)$ & (m) & $(\mathrm{m} / \mathrm{d})$ & \\
\hline $699-17-6$ & 70 & 132.0 & 117.4 & 13.7 & 21.9 & $(0.9)$ & 7.3 & 6 & & $?$ & & & & \\
\hline $698-17-47$ & 474 & 176.1 & 124.4 & 50.3 & 103.6 & (1.5) & 51.8 & 0 & & 15 & 13 & 7 & 13 & \\
\hline $699-18-21$ & $>300$ & 163.8 & 121.6 & 68.5 & 70.7 & 16.3 & 28.5 & & & & & & & \\
\hline $699-20-20$ & 2790 & 154.1 & 121.7 & 32.0 & 43.3 & $(0.3)$ & 10.9 & & & & & & & no gBo \\
\hline $689-24-33$ & 41800 & 159.8 & 122.3 & 35.4 & 43.9 & $\langle 2,1)$ & 6.4 & & & & & & & nogeo \\
\hline $699-24-34 \mathrm{~A}$ & 32600 & 162.7 & 126.2 & 37.2 & 41.8 & $(0.4)$ & 4.2 & & & & & & & no geo \\
\hline $699-24-35$ & 25100 & 164.2 & 123.4 & 39.6 & 44.2 & $(1.2)$ & 3.4 & & & & & & & no geo \\
\hline $699-26-16 \mathrm{~A}$ & 836 & 134.9 & 121.0 & 12.2 & 106.7 & (1.8) & 92.7 & 18 & 47 & 62 & & & & \\
\hline $699-26-36 \mathrm{C}$ & $7430 \cdot 23200$ & 162.2 & 122.4 & 68.8 & 61.9 & 19.0 & 22.0 & 22 & $340-1150$ & & & & & \\
\hline $699-26-89$ & 66 & 199.1 & 147.4 & 50.317 & 148.7 & (1.4) & 97.1 & 0 & & 40 & 0 & 32 & 1 & \\
\hline $699-29-4$ & 121 & 148.9 & 118.7 & 29.3 & 34.9 & $(0.9)$ & 4.0 & & & & & & & no geo \\
\hline $699-31-11$ & 254 & 146.8 & 118.3 & 56.7 & 71.9 & 28.2 & A3.4 & 20 & 13 & & & & & \\
\hline $699-31-31$ & 22850 & 161.3 & 122.3 & 41.11 & 164.6 & 2.1 & 125.6 & 26 & 869 & 46 & 11 & $?$ & & \\
\hline $699-31-53 B$ & $900-1400$ & 215.7 & 123.9 & 89.91 & 131.1 & $(1,8)$ & 39.3 & 0 & & 38 & & & 24-37 & \\
\hline $698-32-72 B$ & 372 & 203.7 & 137.2 & 72.6 & 77.3 & 6.1 & 10.8 & 0 & & 60 & & & 34 & geo from $72 \mathrm{~A}$ \\
\hline $689-32-77$ & 5300 & 199.3 & 143.6 & 53.3 & 88.4 & (2.3) & 32.7 & 0 & & $?$ & & & & \\
\hline $698-33-66$ & $>466$ & 248.6 & 123.7 & 93.7 & 124.7 & $(1.2)$ & 29.8 & 0 & & 27 & & . & $>27$ & \\
\hline $689-35-9$ & $<1150$ & 152.3 & 116.9 & 33.5 & 36.6 & (1.9) & 1.1 & 0 & & 18 & & & $<64$ & \\
\hline $699-36-61 \mathrm{~A}$ & 4920 & 228.0 & 124.4 & 100.6 & 118.6 & (3.0) & 14.9 & 0 & & $?$ & & & & \\
\hline $699-37-82 A$ & 25 & 194.1 & 143.8 & 45.7 & 63.3 & (4.5) & 3.1 & 0 & & 73 & & & 8 & \\
\hline $699-40-1$ & 3000 & 133.7 & 110.1 & 99.8 & 67.1 & (3.8) & 43.4 & 10 & 305 & 9 & 35 & & & \\
\hline $699-40-33 \mathrm{~A}$ & 27 & 157.9 & 123.9 & 32.3 & 56.4 & $(1.7)$ & 22.4 & 0 & & 1 & 9 & 8 & 25 & \\
\hline $699-40-62$ & 1390 & 227.9 & 119.4 & 102.1 & 106.1 & $(6.4)$ & 0.0 & 0 & & 6 & & & 244 & \\
\hline $699-41-23$ & 1800 & 742.2 & 120.8 & 19.8 & 35.1 & (1.6) & 13.7 & & & & & & & no gea \\
\hline $699.42 .12 A$ & 6570 & 156.7 & 114.1 & 36.6 & 97.6 & (6.1) & 54.8 & 0 & & 29 & 14 & & 260 & \\
\hline $699-42-37$ & 28 & 158.2 & 124.9 & 44.0 & 47.1 & 10.7 & 13.8 & 0 & & 0 & 16 & 17 & & \\
\hline $699.42 .40 A$ & 38 & 166.3 & 122.7 & 42.7 & 52.1 & $(0.9)$ & 8.5 & & & & & & & no geo \\
\hline $699-42-40 \mathrm{C}$ & 28 & 166.5 & 126.2 & 93.3 & 118.9 & 52.0 & 77.6 & & & & & & & no geo \\
\hline $699-42-42 B$ & 13 & 177.8 & 128.7 & 56.7 & 62.0 & 6.7 & 13.0 & & & & & & & no geo \\
\hline $699-43-416$ & 29 & 168.0 & 126.0 & 67.4 & 60.5 & 15.3 & 18.5 & & & & & & & no geo \\
\hline $699-43-42 K$ & 8.8 & 177.1 & 127.4 & 45.7 & 79.9 & $(4.0)$ & 30.2 & & & & & & & no geo \\
\hline $699-43-43$ & 3440 & 176.6 & 128.0 & 48.6 & 54.7 & 0.0 & 6.1 & & & & & & & nogeo \\
\hline $699-43-89$ & 1770 & 196.3 & 141.4 & 53.3 & 75.3 & (1.6) & 20.4 & & & & & & & no geo \\
\hline $698 \cdot 43 \cdot 104$ & 26 & 233.5 & 160.4 & 84.7 & 104.2 & 1.6 & 21.1 & 0 & & 10 & D & 7 & 3 & \\
\hline $699-44 \cdot 42$ & 7060 & 176.5 & 129.8 & 46.4 & 52.6 & $(0.3)$ & 5.8 & & & & & & & no geo \\
\hline $699-46.21 \mathrm{~B}$ & 362 & 159.1 & 118.8 & 40.5 & 67.1 & 0.2 & 26.8 & 0 & & 40 & $?$ & & 9 & \\
\hline $699-47-36 \mathrm{C}$ & 49 & 145.2 & 120.1 & 21.3 & 30.6 & (3.8) & 5.4 & 0 & & 0 & 0 & 6 & 8 & geo for $35 \mathrm{~A}$ \\
\hline $699-47-60$ & 316 & 198.1 & 122.7 & 71.6 & 84.4 & $(3.8)$ & 9.0 & 0 & & 9 & & & 34 & \\
\hline $699-48-18$ & 362 & 129.5 & 112.4 & 18.3 & 22.8 & 1.2 & 5.7 & 6 & 57 & & & & & \\
\hline $699-48.77 \mathrm{C}$ & 604 & 205.4 & 139.6 & 64.3 & 68.9 & (1.5) & 3.1 & & & & & & & no geo \\
\hline $699-52-54$ & 186 & 173.3 & 123.8 & 47.7 & 50.9 & (1.8) & 1.4 & & & & & & & nogeo \\
\hline $699-52.67$ & 11 & 171.2 & 124.0 & 42.4 & 48.6 & (4.8) & 1.3 & & & & & & & no geo \\
\hline $699-63-65 \mathrm{~A}$ & 6130 & 175.7 & 123.5 & 50.3 & 82.3 & (20) & 30.0 & & & & & & & no geo \\
\hline $699.65 .50 \mathrm{~A}$ & 37200 & 135.0 & 122.5 & 12.2 & 30.5 & 10.3) & 18.0 & 12 & 3147 & 0 & 0 & 6 & & \\
\hline $699-65-60 \mathrm{~A}$ & 6950 & 174.6 & 119.8 & 67.9 & 70.1 & 3.1 & 15.2 & & & & & & & no geo \\
\hline 699-57-83A & 65 & 176.2 & 131.6 & 45.7 & 59.4 & 1.1 & 14.8 & & & & & & & no geo \\
\hline $699-60.67$ & 825 & 143.1 & 121.0 & 16.8 & 42.1 & (5.4) & 19.9 & 22 & 38 & & & & & \\
\hline $699-61-66$ & 16300 & 159.1 & 124.6 & 32.0 & 48.8 & (2.5) & 14.2 & 14 & 1145 & 17 & & & & \\
\hline $699-62-43 B$ & 4650 & 129.0 & 120.8 & 7.6 & 22.3 & $(0.6)$ & 14.1 & 13 & 351 & & & & & \\
\hline $699-63-68$ & 10600 & 149.9 & 122.1 & 24.7 & 36.9 & (3.1) & 9.1 & 6 & 1864 & 3 & & & & \\
\hline $699-63-90$ & 5860 & 155.4 & 121.0 & 29.0 & 44.8 & (5.4) & 10.4 & 4 & 1607 & 34 & & & & \\
\hline $699-65-50$ & 5960 & 142.3 & 121.7 & 16.8 & 38.1 & (3.9) & 17.5 & 8 & 667 & 2 & 42 & & & \\
\hline $699-71.30$ & 100 & 122.1 & 113.7 & 7.6 & 26.2 & $(0.8)$ & 17.8 & 3 & 33 & & & & & \\
\hline $699-71.52$ & 372 & 159.4 & 121.6 & 36.6 & 48.8 & (1.4) & 10.8 & 1 & 271 & 7 & & & & \\
\hline $699-71-77$ & 4090 & 143.9 & 120.5 & 18.3 & 87.8 & (5.1) & 64.4 & 3 & 1592 & 28 & $?$ & & & \\
\hline $699-72.73$ & 2070 & 146.9 & 920.6 & 18.3 & 53.6 & $(8.0)$ & 27.4 & 0 & & 25 & & & 84) & \\
\hline 699.77 .64 & 321 & 146.5 & 121.0 & 21.3 & 36.6 & $(4.1)$ & 11.1 & 4 & 87 & 17 & & & & \\
\hline 699.86 .60 & 865 & 138.1 & 119.8 & 15.2 & 152.4 & $(3.0)$ & 134.1 & 11 & 78 & 0 & 10 & 11 & & \\
\hline $699-87-56$ & 181 & 139.8 & 118.6 & 18.0 & 28.0 & (3.3) & 6.7 & 0 & & $?$ & & & & \\
\hline
\end{tabular}

C. 2 


\section{Appendix D}

Well Cluster Sites and Wells with Piezometers in the

Unconfined Aquifer System 


\begin{tabular}{|c|c|c|c|c|c|c|c|c|}
\hline Well & $\begin{array}{c}\text { Well } \\
\text { Diameter } \\
\text { (in.) } \\
\end{array}$ & $\begin{array}{l}\text { Original } \\
\text { Interval } \\
\text { (it bls) } \\
\end{array}$ & $\begin{array}{c}\text { Current } \\
\text { Interval } 1 \\
\text { (ft bls) } \\
\end{array}$ & $\begin{array}{c}\text { Current } \\
\text { Interval } 2 \\
\text { (tt bls) }\end{array}$ & $\begin{array}{c}\text { Current } \\
\text { Interval } 3 \\
\text { (ft bls) }\end{array}$ & $\begin{array}{c}\text { Current } \\
\text { Interval } 4 \\
\text { (ft bls) } \\
\end{array}$ & $\begin{array}{c}\text { Current } \\
\text { Interval } 5 \\
\text { (ft bls) } \\
\end{array}$ & \begin{tabular}{|c} 
Notes \\
\end{tabular} \\
\hline 199-H4-15C & 10 & - & $578-80$ & A 194-196 & Q 295-297 & P $325-327$ & & bentonite seals, screens, $P$ in basalt \\
\hline 299-W22-24 & 8 & $220-575$ & T 292-317 & $\$ 352-377$ & A412.437 & Q475-497 & $P 537-561$ & cement seals. \\
\hline 299-E23-2 & 8 & $304-456$ & $0320-340$ & Q 380-400 & P 436-456 & & & cement seals \\
\hline $299-$ E27-3 & 8 & $265-360$ & $0280-300$ & $P 340-360$ & & & & O piezo broken, no seals documented \\
\hline 699-S41-E13A & 4 & $47-57$ & & & & & & screen \\
\hline 699-S41-E13B & 4 & $77-87$ & & & & & & screen \\
\hline 699-S41-E13C & 4 & $111-121$ & & & & & & screen \\
\hline 699-S18-E2A & 8 & $70-260$ & 200 & 259 & & & & no seals, piezos broken, goes to basalt \\
\hline 699-S18-E2B & 8 & $60-100$ & & & & & & \\
\hline 699-S12-29 & 8 & $83-175$ & 83-115? & Q 150-155 & $P 185 \cdot 190$ & & & \\
\hline $699-2-33 A$ & 8 & $130-405$ & $130-180$ & & & & & plug at 180 \\
\hline $699-2-33 \mathrm{~B}$ & 8 & $?-450$ & $?-170$ & Q335-340 & P440-445 & & & plug at 270 \\
\hline 699-10-E12 & 8 & $60-340$ & Q95-100 & $P 360-365$ & & & & \\
\hline 699-14-E6 & 1.5 & $\cdot$ & $\$ 290-300$ & & & & & separate well, $P, Q, \bar{R}$, and $T$ destroyed \\
\hline $699-14-38$ & 8 & $110-409$ & $110-165 ?$ & Q 175-180 & P 415-420 & & & annulus interval $110-165$ ? \\
\hline $699-15-15 A$ & $\overline{8}$ & $140-635$ & $140-190$ & $\overline{P 205-216}$ & & & & plug at 190 \\
\hline 699-15-15B & 6 & $141-161$ & & & & & & \\
\hline $699-17-26 \mathrm{C}$ & 8 & $?$ & Q 155-160 & P $186-189$ & & & & no seals documented \\
\hline $699-18-25$ & $?$ & - & ค 278-288 & Q 479.489 & P668-678 & & & Q piezo broken, no seals documented \\
\hline $699-19-26 \mathrm{~B}$ & $?$ & $?$ & Q 131.136 & P 189-194 & & & & no seals documented \\
\hline 699-20-E5 & 1.5 & -1 & $T 113-123$ & $5210-220$ & R 300-310 & Q 409-419 & P444-454 & separate wells, $P$ and $Q$ in basalt \\
\hline 699-20-E12 & 8 & $65-344$ & $080-100$ & $5113-138$ & A 178.198 & Q228-253 & $\mathrm{P} 320-345$ & $P$ in basalt, 0 piezo missing \\
\hline $699-20-39$ & 8 & $130-632$ & $130-490$ & $\mathrm{P} 608-618$ & & & & plug at $490, P$ in basalt \\
\hline $699-24-1$ & 1.5 & $\therefore$ & $T 124-134$ & $5211-221$ & A 304-314 & Q 327-337 & P 446-456 & separate wells, $\mathrm{P}$ in basalt \\
\hline $699-25-33 \mathrm{~A}$ & 4 & $191-200$ & & & & & & screen \\
\hline $699-25-33 B$ & 8 & $?$ & Q 188-193 & P215-220 & & & & screens \\
\hline $699-26 \cdot 35 A$ & 5 & $120-140$ & $120-140$ & & & & & 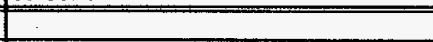 \\
\hline $699-26-35 \mathrm{C}$ & 4 & 193-203 & 193-203 & & & & & \\
\hline $699-28-40$ & 8 & $150-465$ & $?$ & Q 340-350 & $\mathrm{P} 452-462$ & & & plug at 320, P piezo missing \\
\hline $699-31-31$ & 8 & $135-540$ & $135-270$ & Q 360-370 & $\mathrm{P} 590-600$ & & & plug at 270 , P piezo missing \\
\hline $699-31-53 A$ & 12 & $301-423$ & $228-340$ & & & & & plug at 340 \\
\hline 699-31-53B & 12 & $306-430$ & $0300-320$ & $\bar{P} 410-430$ & & & & no seals documented \\
\hline $699-31-65$ & 8 & 240.450 & $0240-260$ & R $310-330$ & Q 370-390 & P410-430 & & piezos removed \\
\hline $699-32-62$ & 8 & $275-500$ & $275-340$ & Q 365-375 & $P 490-500$ & & & plug at 340, Q piezo blocked \\
\hline $699-32-72$ & 8 & $210-485$ & $210-415$ & P 465-470 & & & & plug at 415 \\
\hline $699-36-46$ & 1.5 & - & $5300-310$ & R 370-380 & Q 400-450 & $\mathrm{P} 510-520$ & & separate wells, $Q$ and $P$ in basalt \\
\hline 699-37-82A & $?$ & $221-408$ & & & & & & condition unknown \\
\hline 699-37-82B & 8 & $163-590$ & $0165-185$ & $5230-250$ & R $310-330$ & Q 390-410 & P540-560 & $T$ removed; $P, Q$ and $O$ broken \\
\hline $699-37-82 \mathrm{C}$ & $\overline{8}$ & $165-279$ & & & & & & condition unknown \\
\hline 699-37-82D & $?$ & $155-190$ & & & & & & condition unknown \\
\hline $699-38-65$ & 8 & $220-536$ & $220-440$ & $P 460-536$ & & & & plug at $420-440$ \\
\hline 699-42-E9A & 11 & $021-42$ & $P 221-232$ & & & & & P was abandoned \\
\hline 699-42-12A & 8 & $120-320$ & $120-180$ & & & & & plug at 180 \\
\hline $699-42-12 B$ & 12 & $140-240$ & & & & & & \\
\hline $699-42-12 \mathrm{C}$ & 6 & 155 & & & & & & not perforated \\
\hline $699-51-75$ & 8 & $190-370$ & 190-235 & P 245-382 & & & & plug at $235-245$ \\
\hline
\end{tabular}




\begin{tabular}{|c|c|c|c|c|c|c|c|c|}
\hline Well & $\begin{array}{c}\text { Well } \\
\text { Diameter } \\
\text { (in.) }\end{array}$ & $\begin{array}{l}\text { Original } \\
\text { Interval } \\
\text { (ft bls) } \\
\end{array}$ & $\begin{array}{c}\text { Current } \\
\text { Interval } 1 \\
\text { (ft bls) }\end{array}$ & $\begin{array}{c}\text { Current } \\
\text { Interval } 2 \\
\text { (it bls) } \\
\end{array}$ & $\begin{array}{c}\text { Current } \\
\text { Interval } 3 \\
\text { (ft bls) }\end{array}$ & $\begin{array}{c}\text { Current } \\
\text { Interval } 4 \\
\text { (tt bls) } \\
\end{array}$ & $\begin{array}{c}\text { Current } \\
\text { Interval } 5 \\
\text { (ft bls) } \\
\end{array}$ & $\begin{array}{r}\text { Notes } \\
\end{array}$ \\
\hline $699-53-55 A$ & 8 & $160-455$ & $165-270$ & P310-455 & & & & perf. $160-190 \& 255-275, \mathrm{P}$ in basalt \\
\hline 699-55-50A & 8 & $40-100$ & $064-78$ & P 96-98 & & & & seals not documented \\
\hline $699-55-50 \mathrm{C}$ & 8 & $35-59$ & $35-56$ & & & & & plug at 56 \\
\hline 699-55-50D & 8 & $33-90$ & $33-90$ & & & & & \\
\hline 699-55-60A & $\overline{12}$ & $190-230$ & & & & & & \\
\hline 699-55-60B & 24 & $230-285$ & & & & & & \\
\hline $699-55-60 \mathrm{C}$ & $?$ & $?$ & & & & & & condition unknown \\
\hline $699-55-70$ & $\overline{\overline{8}}$ & $136-202$ & $136-180$ & $\mathrm{P} 190-195$ & & & & cement plug at 180 \\
\hline 699-55-95 & 8 & $325-530$ & $325-385$ & $0450-460$ & $\mathrm{P} 508-518$ & & & no seals documented, gravel backfill \\
\hline $699-67-51$ & 8 & $100-250$ & $100-170$ & Q 184-194 & $\mathrm{P} 230-235$ & & & plug at 170, cement seals \\
\hline $699-69-45$ & $\overline{8}$ & $80-300$ & $097-117$ & $\overline{\mathrm{B} 153-178}$ & Q210-235 & $\mathrm{P} 255-277$ & & cement seals \\
\hline $699-80-43$ & $?$ & $?$ & S 30-50 & R $116-140$ & Q212-230 & P 437-447 & & airlines in piezos \\
\hline $699-84-35$ & 8 & $10 \cdot 355$ & $010-?$ & $5127-153$ & R191-217 & Q 255-281 & P 325-351 & \\
\hline $699-96-49$ & $\overline{8}$ & $28-96$ & $28-60$ & P70-96 & & & & plug at $60-70$ \\
\hline
\end{tabular}

$\underset{i}{\forall}$ 


\section{Distribution}

No. of

Copies

\section{OFFSITE}

J. S. Bachmaier

Office of Environmental Policy

and Assistance

U.S. Department of Energy

1000 Independence Ave. SW

Washington, D.C. 20585

R. Buck, Jr.

Wanapum Indian Band

P.O. Box 878

Ephrata, WA 98823

N. Buschman

U.S. Department of Energy

EM-20.1

Clov Room 1105

19901 Germantown Rd.

Germantown, MD 20874

C. Caprio

Jason, Assaciates

3250 Port of Benton Boulevard

Richland, WA 99352

2 C. Cline

Washington State Department of Ecology

P.O. Box 47600

M.S. 7600

Olympia, WA $98504-7600$

R. A. Danielson

Washington State Department of

Health

2 South 45th Ave.

Yakima, WA 98908

B. Drost

U.S. Geological Survey

1201 Pacific Ave., Suite 600

Tacoma, WA 98402
No. of

Copies

2 M. Dunkleman

J. Erickson

Washington State Department of

Health

Division of Radiation

Protection

P.O. Box 47827

Olympia, WA $98504-7827$

2 T. Gilmore

J. R. Wilkerson

Environmental Planning/

Rights Protection

Confederated Tribes of the

Umatilla Indian Reservation

Hanford Projects

P.O. Box 638

Pendleton, OR 97801

M. Harmon

U.S. Department of Energy

656 Quin Orchard Road

Building QO

Gaithersburg, MD 20585

2 S. Harris

D. Powaukee

Environmental Restoration/

Waste Management

Nez Perce Tribe

P.O. Box 365

Lapwai, ID 83540-0365

2 R. Jim

B. A. Cook

Yakama Indian Nation

Environmental Restoration/

Waste Management

P.O. Box 151

Toppenish, WA 98948

R. Patt

Oregon State Department of

Water Resources

3850 Portland Road

Salem, OR 97310

Distr.1 
No. of

Copies

\section{ONSITE}

38 DOE Richland Operations Office

G. M. Bell

E. M. Bowers

R. F. Brich

N. R. Brown

A. K. Crowell

T. W. Ferns

R. D. Freeberg

M. J. Furman

C. H. Gunion

J. B. Hall

C. E. Hanson

R. D. Hildebrand (10)

R. G. Holt

R. A. Holten

S. T. Hwang

J. E. Kinser

L. K. McClain

R. G. McLeod

D. E. Olsen

P. M. Pak

L. L. Piper

J. E. Rasmussen

R. M. Rosselli

C. O. Ruud

R. Quintero

R. K. Stewart

K. M. Thompson

A. C. Tortoso

D. M. Wanek

16 Bechtel Hanford, Inc.

R. L. Biggerstaff

J. V. Borghese

M. P. Connelly

G. R. Chiaramonte

K. R. Fecht

L. C. Hulstrom

R. L. Jackson

G. L. Kasza

A. J. Knepp

M. J. Lauterbach

D. A. Myers

D. L. Parker

R. E. Peterson

L. C. Swanson

S. J. Trent

S. R. Weil
No. of

Copies

1 Mac Tech

S. D. Barry

S7-73

A5-52

S7-55

A5-19

K6-51

S7-55

$\mathrm{H} 4-83$

A5-19

R3-81

S7-41

A5-55

H5-09

$\mathrm{H} 4-83$

A4-83

R3-81

A5-18

S7-50

H4-83

A5-19

H4-83

A5-19

R3-78

A5-15

K8-50

S7-54

A5-54

A5-19

A5-19

H4-83

A5-19

H4-91

H6-04

H6-07

H6-01

H4-80

H6-01

H6-04

H6-04

H4-80

H6-01

H4-79.

H6-02

H6-05

H6-03

H4-80

H4-80

3 U.S. Environmental Protection Agency

P. R. Beaver

B5-01

D. A. Faulk B5-01

L. E. Gadbois B5-01

3 Washington State Department of Ecology

D. N. Goswami (3) N1-05

6. Westinghouse Hanford Company

D. B. Barnett H6-06

J. D. Davis H0-33

V. G. Johnson H6-06

J. C. Sonnichsen H6-23

R. R. Thompson H6-32

J. S. Schmid H6-06

55 Pacific Northwest National Laboratory

M. P. Bergeron

K9-33

B. N. Bjornstad

K6-81

R. W. Bryce

K6-96

J. W. Buck

K6-80

C. R. Cole

K9-36

J. L. Devary

P. E. Dresel

K9-56

M. J. Fayer

K6-96

W. T. Farris

M. D. Freshley

K9-33

K3-54

S. M. Goodwin

K9-36

T. L. Liikala

K6-81

P. E. Long

K9-48

S. P. Luttrell (5)

K9-48

J. P. McDonald

K6-96

J. T. Rieger

K6-96

F. A. Spane, Jr.

K6-96

P. D. Thorne (5)

K6-96

V. R. Vermeul

K6-96

W. D. Webber

K6-96

K6-96

S. K. Wurstner (20)

K9-36

Information Release Office (7) K1-06 